SCIENTIFIC ENQUIRY IN THE CONTEMPORARY WORLD:

THEORETICAL BASICS AND

INNOVATIVE APPROACH

Research articles

$9^{\text {th }}$ edition

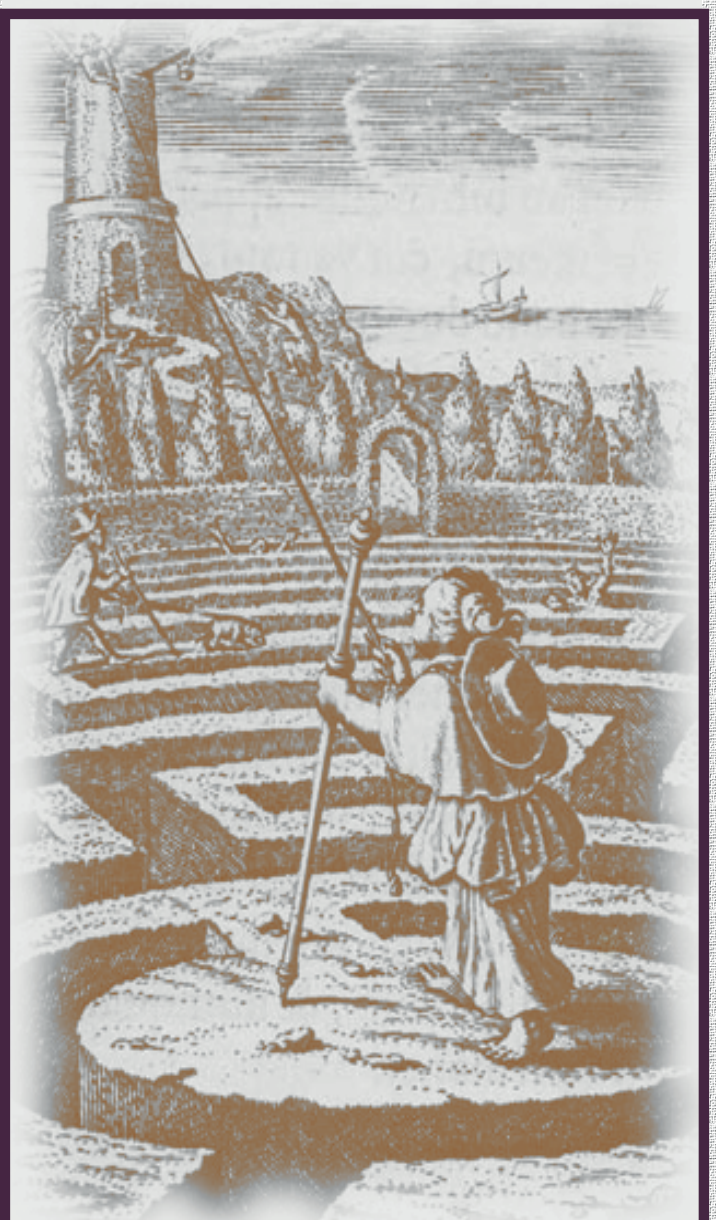




\section{SCIENTIFIC ENQUIRY IN THE CONTEMPORARY WORLD: THEORETICAL BASICS AND INNOVATIVE APPROACH}

9th edition

Research articles 


\title{
SCIENTIFIC ENQUIRY IN THE CONTEMPORARY WORLD: THEORETICAL BASICS AND INNOVATIVE APPROACH
}

\author{
Science editor: R. Draut
}

Copyright (C) 2017

by Research and Publishing Center "Colloquium"

All rights reserved.

Published by B\&M Publishing.

San Francisco, California
ISBN-10:1-941655-46-7

ISBN-13:978-1-941655-46-7

DOI: http://doi.org/10.15350/L_26/9 


\section{CONTENTS}

\section{JURISPRUDENCE}

$\begin{array}{ll}\text { Features of regulation of international jurisdiction in the CIS } & 6\end{array}$

N. Irodenko

The methodological basis law-interpret activity

E. Terekhov

Euthanasia in modern world

K. Vladimirova, A. Galkina, I. Kondrashova

Problems of small business development in Russia

E. Dmitrieva, I. Kondrashova

\section{PEDAGOGY}

Introduction of innovative technologies in the process of learning a foreign

language in high school

U. Yuldasheva, Z. Akhmedova

Individually-differentiated approach in teaching a foreign language in not

language high school

T. Islamova

Development discursive competence of students of not language high schools

in the study of foreign languages

D. Madalaieva

Use the grammar rules in the practical language acquisition

M. Nabiyeva

Motivational mechanism regulatory strategy as learning a foreign language

N. Hashimov

Formation bilingual competence of students in the process of studying

languages

M. Aripova

Using various forms of visualization of grammatic constructions of foreign

language

D. Zakirova

Use of modern equipment for training Chinese language to hieroglific letters

Z. Abdurakhmanova

Application of web quest technologies in training foreign language

N. Abdurakhimova

Use of audiovisual funds in the learning of Chinese language

N. Abdullaeva

Theoretical and practical aspects of intensive training for Arabic language

K. Kadyrova

The application of "creative workshops" in the training of the Chinese

language in the university

Yu. Zhumanazarova

\section{PHILOLOGY}

Difficult behavior of children with disabilities in foster families

L. Aslamazova

Professional consciousness as a component of an image I

A. Klimanova, N. Ezhkova 
Method of studiying interpersonal feedback in business communication

A. Belov

The influence of R. Wagner's music on the work of the english writer

K.S. Lewis

L. Efimova

Varieties of the genre in K.S Lewis's novel "The space trilogy"

L. Efimova

\section{HISTORICAL SCIENCES}

Missionary historical-ethnographic museum of the Kazan theological academy

(1912-1919): contribution to the preservation of historical and cultural

heritage of the peoples of the Volga region, Urals and Siberia

M. Khabibullin

History of physical culture and sports in the Simbirsk province in

1852-1939 (theoretical review)

V. Nazmutdinova, G. Nazmutdinova

\section{ECONOMICS}

Increase in investment appeal joint-stock companies in Uzbekistan

B. Usmanov

Practice of economic analysis methods in researches of information

confrontation

G. Tsvetkova, A. Eshpoldina

Analysis and prognostication of economic efficiency of business entity's

international trading under uncertain economy based on the modelling

of a learning curve

O. Martyanova

Features of the taxation of real estate individuals in the USA

Yu. Lvov

Social protection as a developing social institution

S. Kasymova

Interaction of finance, credit and real sector of economics

V. Koreshkov, I. Makelko

Development of methodical approaches to the creation of new knowledgebased growth points

M. Abuzyarova

Development of methodical approaches to the resource efficient use of hydrocarbons

o. Andreev

Competitiveness assessmeht based on SWOT-analysis

M. Sheaa

Social tourism and its development prospects in the region

M. Kenzhebayeva

The state and problems of livestock production in Kazakhstan

O.Zh. Dossymova, D. Atasheva, N.Zh. Dossymova

Simplified taxation small and medium business in Ukraine and ways to improve

A. Abramova 
Public finance management in Georgia

M. Chelidze, G. Gelitashvili

Banking products and servises: scientific approach

186

A. Zhavoronok

\section{BIOLOGICAL SCIENCES, BIOMECHANICS}

Larval trematode infections in freshwater snails viviparus viviparus, lymnaea stagnalis \& planorbarius corneus from the oredezh river and the park zone of St. Petersburg

A. Brusser

\section{TECHNICAL SCIENCE}

The algorithm for determining pathological objects on medical images

A. Zhukov, R. Tomakova, A. Brezhneva

Chest x-ray analysis using the combined classifier

R. Tomakova, E. Abolmasova, E. Emelyanova, J. Shepeleva

Regeneration method study of used motor oils

M.Zh. Almagambetova, A. Dyussenova

Disturbance of hemostasis in alloxan diabetes and ways its correction

D. Tursunov, R. Sabirova, A. Ikramov, M. Kulmanova, A. Ergashov

Method of selection and operation of pumps with regulation of change of

frequency of rotation of shaft of the submersible electric pumping equipment O. Kurbonov

The indices of platelet homeostasis in women with a metabolic syndrome in the pre-and postmenopausal period

N. Islamova, N. Mukhamedova 


\title{
JURISPRUDENCE
}

\section{FEATURES OF REGULATION OF INTERNATIONAL JURISDICTION IN THE CIS}

\section{N. Irodenko ${ }^{1}$}

\begin{abstract}
The essence of the institute of international jurisdiction in the context of multilateral agreements within the CIS has been represented. The character and features of regulation of relations within the jurisdiction of international legal agreements concluded between the CIS countries have been defined. The features of international legal institutions securing contractual and exclusive jurisdiction in accordance with the Conventions on Legal Assistance and Legal Relations in Civil, Family and Criminal Cases dated of January 22, 1993 and dated of October 07, 2002 have been observed.
\end{abstract}

Keywords: CIS, international jurisdiction, contractual jurisdiction, Convention on Legal Assistance, international economic relations.

Topicality of research. The intensification of business and economic development is an integral feature of modern geoeconomic processes regardless of their distribution areas and nature of participants. The Post-Soviet space as a geopolitical characteristics of a number of countries formed after the collapse of the USSR has been traditionally seen as a receptor of the more economically and politically powerful countries. Russia's attempts to become a world leader and take over the role of the USSR in the world of law architectonics do not have great success today, Russia itself is the centre of the bifurcation of the world order, an element of destruction of the postwar world. Despite this, the political authorities of Russia have been trying to unite the once friendly member states of the USSR veiling their political and economic pressure in the form of integration and the creation of a single market. There is a number of integration associations in the former USSR, for example such as the CIS, EAEU, CSTO and others. Although the experience of their operation does not have such success as similar regional economic alliances in other parts of the world, but the fact of their presence and practice of activities witnessed some positive trends in the socioeconomic cooperation. The greatest efficiency in commercial, civil and other areas of public relations has been achieved in the CIS that made it possible in particular by the adoption of several important international legal conventions, the special place among them is occupied by Minsk (1993) and Chisinau (2002) Conventions on

${ }^{1}$ Nadiia Irodenko, PhD student, Taras Shevchenko National University of Kyiv Institute of International Relations, Ukraine. 
Legal Assistance and Legal Relations in Civil, Family and Criminal Cases as well as Kyiv Agreement on the Procedure of Settlement of Disputes relating to carrying out economic activity in 1992. The analysis of the regulations of these conventions, in particular in terms of settlement of jurisdiction will allow to assess the efficiency and prospects of bilateral relations within the CIS.

Literature Review. The problems of international legal regulation of relations within the CIS have been investigated by the following scientists: S. M. Berveno, V. M. Haivoronskyi, V. P. Zvekov, G. A. Tsirat et al.

However, despite the long period of stay of Ukraine in CIS, today there is a number of contentious issues and the practical application of certain conventions and international legal agreements signed within the CIS.

Aim of article. The aim of this article is to analyse the characteristics of regulation of international jurisdiction in the CIS based on the research of regulations of the following international instruments: Kyiv Agreement on the Settlement of Disputes relating to carrying out economic activity in 1992, Minsk (1993) and Chisinau (2002) Convention on Legal Assistance and Legal Relations in Civil, Family and Criminal Cases.

Material. Commonwealth of Independent States (hereinafter - CIS) had been regarded by Ukraine as a potential alternative way to realize their economic potential by 2014. The participation of Ukraine in the CIS, even without ratification of the Statute of organization, put it in a specific situation, but nevertheless made it possible to use most of the trade and economic preferences offered by the Commonwealth.

In terms of geo-economic and geopolitical importance the CIS was rather a political alliance than a pure economic integrative formation, but nevertheless the system of international legal agreements established within the CIS, made it possible to significantly simplify the business procedures among the entities of the member states. The presence of economic ties, common law systems and the availability of indissoluble (due to the common historical past) connections determined the necessity to create certain conditions for the full realization of persons (both individuals and entities) of the entire spectrum of civil and economic rights guaranteed by the international system and international legal acts. One of these rights is the right to a trial. In terms of international relations, it is closely related to the choice of courts. The necessity for resolving the problems of jurisdiction is objectified, and in the CIS this problem is solved by a number of international legal agreements and conventions. It is true that the international legal agreements concluded within the CIS relating to Cases of jurisdiction have two significant disadvantages:

- first, they are unsystematic, and the nature of international legal regulation is fragmented. As a whole, it is disclosed by the availability of large number of bilateral and multilateral agreements on international jurisdiction, but not all such agreements cover the full range of contentious issues. Regarding Ukraine it should be noted that the expense and cost recovery issues in proceedings with foreign element that is a resident or citizen of the member state of the CIS have not been settled, because Ukraine has not ratified the relevant Agreement on 
Amount of State Duty and Procedure of Its Collection When Considering Economic Disputes between the Economic Entities of Different States (1993) and the Agreement on Procedure of Mutual Enforcement of Commercial and Economic Courts on the territory of the Member States of the CIS (1998).

- second, today the CIS is not the only judicial body that would be a real alternative to resolve disputes among the various entities of the member states of the CIS or their citizens.

As for the regulation of the jurisdiction within the CIS it is advisable to pay attention to the following.

S. M. Berveno points out that the definition of jurisdiction in international law theory is used to establish the distribution of competences among different judicial authorities (national and supranational levels). The competence of the state courts refers to the certain cases only among subjects with appropriate connection with such state as well as cases involving foreign element. From this perspective, jurisdiction is determined exclusively in accordance with domestic law. In the case of international jurisdiction the characteristics of the competences of jurisdiction courts is being applied [2].

V. P. Zvukov defines international jurisdiction as a distinction of the competences of national courts of various countries to solve cases with a foreign element [4].

In this case, there is no special matter concerning the category of cases that is regarded, because in any case whether it is a civil litigation or criminal or commercial proceedings, in terms of entity's availability of appropriate relationships to protect their rights, such protection can be implemented by means of international jurisdiction.

Based on works of V.A. Bigun, G.A. Tsirat indicates that the concept of "jurisdiction" may be expressed as statutory right to judicial and only judicial authorities of the state to accept for trial, to consider and decide Cases with the participation of a foreign element. In this case, using the notion of "international jurisdiction", first, the question of the responsibility of a state to resolve an issue is being solved, i.e. distribution of powers between the jurisdictions of different states is being carried out; second, only then the question of determining the specific authority of the State authorized to solve this kind of Cases should be raised [10].

In turn, V.E. Belyanevych indicates the issue of jurisdiction to be one of the major issues facing the opening of proceedings of the decision before the court. Establishing jurisdiction of a case with a foreign element is carried out in the several stages: definition of international jurisdiction, i.e. the courts of a state competent to decide this case shall be established by a judge; definition of tribal jurisdiction, i.e. the question of jurisdiction of the court proceedings authorized state body to decide the case on the merits (under the jurisdiction of this case economic or civil court is) is being solved; definition of territorial jurisdiction, i.e. to establish which court has territorial feature for jurisdiction to decide a dispute [1].

V.M. Gayvoronsky and V.P. Dushman focus their attention on the features concerning international jurisdiction in civil proceedings. It can take place with the 
written agreement of the parties on the choice of the state court. Although due to the "law court" the case is under jurisdiction of a foreign court or, alternatively, on the transferring of the case to a foreign court. Agreement establishing the jurisdiction of the court in favour of its country is called prorogation, agreement establishing the jurisdiction of the court in favour of a foreign court are called derogation.

It should be noted that the propaganda agreement is defined as the territorial jurisdiction of a case, except those for which exclusive jurisdiction is installed. As a rule, a contract jurisdiction with foreign elements can take place during the period of conclusion of trade agreements. The law regulations on the division of jurisdiction are represented primarily in bilateral treaties on legal assistance and legal relations in civil and criminal Cases, as well as in the homonymous, multilateral Convention on Legal Assistance and Legal Relations in Civil, Family and Criminal Cases dated of January 22, 1993 [7].

Within the CIS, one of the leading places in the system of international legal instruments governing jurisdiction covers agreement procedure for resolving disputes related to economic activity dated of 1992, ratified by the Verkhovna Rada of Ukraine No. 2889-XII dated of December 12, 1992 (hereinafter -Agreement). Thus, in accordance with Art. 3 of this Agreement Business entities of every member state of the CIS exercise the right to judicial protection of their property and legitimate interests equal to Business entities of this state in the territory of another member State. Business entities of every member state of the CIS exercise the right without hindrance to apply to the courts arbitration (commercial) courts, tribunal and other authorities, the competent of which is to solve the Cases referred to in Article 1 of this Agreement they can act, and may request, propose suits and conduct other proceedings [9].

Thus, it should be noted that this Agreement does not contain provisions concerning just the jurisdiction, in fact, effectively replacing the term "jurisdiction" by the concept of "competence of the court". Formally, the change does not have any bindings or restrictions on the settlement of the right to appeal to the court within the CIS, but in terms of terminology certainty it requires some explanation and clarification as in the national legislation of the CIS the terms "jurisdiction", "contract jurisdiction" and so on are mainly represented.

However, special attention is paid to another feature, because there isn't any right of entities to appeal in a particular court in the Agreement, but there is the right to take court proceedings to statements from certain categories of entities or the right to examine certain disputes.

According to Art. 4 of the Agreement the competent court of a member state of the CIS may consider disputes if there is something on the territory of a member state of the CIS, mainly:

- a defendant had a permanent residence or location on the day he / she put in a claim;

- trade, industrial or other business activity of the company (branch office) of the defendant is carried out;

- obligations from the contract that is the subject of the dispute is fully or partly fulfilled; 
- an action or another circumstance that became the basis for a claim for compensation of damage has occurred;

- a plaintiff on the suit about protection of business reputation has a permanent residence or location;

- there is a counterparty, a supplier, a contractor or someone providing services (handling activities), and the dispute relates to conclusion, modification and termination of contracts [9].

It is quite interesting that the analysed Agreement is the first international legal act in the CIS which directly recognizes the institution of contractual jurisdiction. Thus, in accordance with Part 2 of Art. 4 of Agreement the competent courts of the member states of the CIS consider the Cases in other cases, if there is a written agreement between the Parties on putting claim concerning dispute to court. Besides the Agreement fixes the obligation of the courts to provide mutual legal assistance, including the implementation of individual orders, as well as the obligation for the recognition and enforcement of decisions of other courts of the CIS.

In terms of the formation of the system of jurisdiction in the CIS and further relations of the member states of the CIS in the context of execution of judgments of foreign courts, an important regulation is the regulation on empowering the highest judicial authorities of the CIS law to settle disputes in connection with implementation of decisions of the competent courts.

In general, this characteristic as a "competent court" gives the perception that a judicial body is entitled to finally solve the issues on the possibility of the dispute between the parties that have the same state of origin. The overall analysis of Art. 4 demonstrates that the legal structure of this regulation, presentation and mechanism of regulation are identical to the mechanism represented in the Brussels Convention on jurisdiction and enforcement of judgments in civil and commercial Cases dated of 1968.

Another important international legal instrument regulating the jurisdiction of the CIS is the Convention on Legal Assistance and Legal Relations in Civil, Family and Criminal Cases dated of January 01, 1993, signed in Minsk and ratified by the Law of Ukraine No. 240/94-VR dated of November 10, 1994 (hereinafter Minsk Convention).

However, it should immediately be noted that the Convention on Legal Assistance and Legal Relations in Civil, Family and Criminal Cases was signed on October 7, 2002 in Chisinau City. It entered into force, pursuant to Article 120 of this Convention on the thirtieth day the date of deposit of the third instrument of ratification for the Republic of Belarus, the Republic of Azerbaijan and the Republic of Kazakhstan. According to the third and fourth parts of the same article of the Convention dated of 2002 the Convention dated of 1993 and the Protocol dated of March 29, 1997 terminated among member states.

However, the Convention dated of 1993 and the Protocol dated of 1997 will continue to apply in relations among the member states of international treaties and states for which the Convention dated of 2002 has not entered into force. Today the Ministry of Justice of Ukraine carries out activities to prepare pro- 
posals on the ratification of the Convention on Legal Assistance and Legal Relations in Civil, Family and Criminal Cases dated of 2002. Such Convention did not enter into force for Ukraine, and therefore only the Convention dated of 1993 and the Protocol dated of 1997 are in force [11].

Therefore, the Minsk Convention establishes the following general rule for solving the question of jurisdiction within the CIS: claims to persons having permanent residence on the territory of the member states of the CIS are put, regardless of their nationality, to the courts of this state, but claims to legal entities are put in the courts of the state, on the territory of which there is the governing body of the legal entity or its branch office.

If several defendants with residence (location) on the territories of various member states of the CIS are involved in the case, the dispute is considered according to the place of residence (location) of any defendant by the choice of the plaintiff. The courts of a member state of the CIS are competent in those cases when on the territory of this state:

- trade, industrial or other business activity of the company (branch office) of the defendant is carried out;

- or the obligations from the contract that is the subject of the dispute is partly fulfilled;

- a defendant had a permanent residence or location by the claim on protection of honour, dignity and business reputation [5].

- In addition, it should be noted that the Minsk Convention distinguishes the institutions of contractual and exclusive jurisdiction. Thus, in particular the analysis of the regulation of the Convention allows to establish that the exclusive jurisdiction applies if the dispute is solved with immovable property, which can be solved only by the location of such property. The exclusive jurisdiction is observed in disputes arising from contracts of carriage and it is set by the place of actual residence governing body of the carrier.

Contracting jurisdiction is established in Art. 21 of the Minsk Convention, according to which the courts of the member states of the CIS may consider the Cases in other cases, if there is a written agreement of the parties concerning transferring of the dispute to these courts. This exclusive competence, represented in paragraph 3 of Article 20 and other regulations laid down in parts II-V of this section, as well as the domestic law of the Member State of the CIS, cannot be changed by agreement of the parties [5].

The Convention on Legal Assistance and Legal Relations in Civil, Family and Criminal Cases dated of October 07, 2002 fully doubles the provisions of the Minsk Convention in the part relating to contractual and exclusive jurisdiction. From this perspective, it does not present significant interest for Ukraine, because its ratification has not yet taken place. Moreover, in terms of a confrontation between Russia and Ukraine, Ukraine has lost all interest in the CIS as an alternative vector of European integration, and therefore it does not have great necessity for ratification of the Convention dated of October 07, 2002.

Instead, this Convention contains some pretty important regulations in terms of bilateral relations between Ukraine and the CIS countries. In particular, it is the rules governing the procedure for execution of judgments, particularly in 
part of the payment and collection of court costs, collection of state fee for an appeal to the courts and so on.

In particular, the Convention dated of October 07, 2002 contains a separate order of execution of court decisions on fines, forfeiture of property and proceeds of crime [6].

This procedure is extremely important in terms of events occurring recently in Ukraine, namely on foreclosure of former high authorities of Ukraine, who were convicted or under examination in Ukraine, and in fact live in Russia. This Convention has practical importance for Ukraine, but the regulations remain achievable for it due to the fact that Ukraine has declared its withdrawal from the CIS and it actually ignores joint projects and further ratification of signed conventions and agreements.

In addition, the Supreme Economic Court declares that there are a number of shortcomings regarding the actual implementation of the Agreement and the Minsk Convention, because there is no legally established mechanism for recovery of legal costs in the form of payment of state fees from foreign entities in Ukraine.

Thus, solving the dispute involving entities of the member states of the CIS, the courts should take into account that Ukraine has not signed the Agreement on Amount of State Duty and Procedure of Its Collection When Considering Economic Disputes between the Economic Entities of Different States (Ashgabat, December 24, 1993) and the Agreement on Procedure of Mutual Enforcement of Commercial and Economic Courts on the territory of the Member States of the CIS (Moscow, June 03, 1998), and consequently their situation is not valid in Ukraine.

Thus, there is no mechanism for enforcement of the Commercial Court in penalties on foreign entities to the state. So the commercial courts take complaints for trial from foreign entities, and statements about increasing the size of the claim only if the court provides evidence of enrolment in the state budget income amount of state fee in the prescribed amount. In this case, sufficient evidence of the fact of receipt of the state fee to the state budget of Ukraine is the receipt of the territorial authority of the State Treasury of Ukraine [8].

Conclusions. Summing up the analysis of international legal regulation of the institute of jurisdiction within the CIS the next should be noted. First, due to the fact that Ukraine did not ratified all international instruments operating in the CIS and they are related to regulatory issues on jurisdiction, as well as taking into account inconsistency of this regulation, lack of integrity in existing agreements and legal structures, it can be concluded about the lack of efficiency of the agreements and conventions, the analysis of which was represented in this article. In particular, we are talking about the Agreement on the Procedure of Settlement of Disputes relating to carrying out economic activity dated of 1992; the Convention on Legal Assistance and Legal Relations in Civil, Family and Criminal Cases dated of January 01, 1993 and dated of October 07, 2002.

Second, the above-mentioned conventions and agreements contain regulations governing institution of exclusive and contractual jurisdiction. Moreover, the construction of these regulations demonstrates their borrowing from other 
international agreements and conventions, including the Brussels I. In addition, the value of transactions analysed in terms of socio-economic relations and cooperation within the CIS is very high, because it significantly simplifies the settlement of disputes between the member states of the CIS that have not ratified any other international legal acts on issues of jurisdiction.

In general, the regulations of international legal agreements within the CIS have value for Ukraine only continuing its participation in the organization. Otherwise, in the context of determining of jurisdiction the more appropriate is bilateral agreements between Ukraine and individual member states of the CIS between business entities which have close economic ties.

That is why, in our opinion, it is appropriate to offer so-called matrix model of international legal relations to determine the issue of jurisdiction in international disputes in commercial activities within the CIS or rather on the member states of the CIS. Leaving the membership of the CIS, Ukraine will get rid of close economic ties between its members. After the agreements on jurisdiction of the CIS terminate by virtue of the withdrawal from the signatory countries of Ukraine, the latter part shall initiate the signing of a framework agreement between all member countries of the Commonwealth for which the decision on the preservation of economic and political contact will be resolved.

This framework agreement will provide the distribution of economic activities of residents of Ukraine of the regulations of the agreements on jurisdiction in international commercial disputes of the CIS. A separate regulation or a separate new mechanism will not be established due to its essential content. In addition, the existing mechanism for the settlement of international jurisdiction on a certain number of countries will be implemented in the new agreement that will be concluded by the same states except Ukraine, which at the time of its signing out leave the CIS.

This practice is well-known and it is particularly observed in Iceland and Switzerland (these states have certain framework obligations with the EU on certain trading operations, although they are not member states of the EU). This practice will be a novel for Ukrainian international private law, but the signing of this framework agreement without the actual membership significantly reduce the settlement procedure of international jurisdiction between the economic entities of Ukraine and the member states of the CIS, as well as it significantly unifies the relevant regulations, because it will help to get rid of the necessity to conclude a separate agreement be every state, receiving a single unified agreement of all member states of the CIS.

\section{References:}

[1] Беляневич B.Е. Господарський процесуальний кодекс України: наук-практ. комент. К.: Видавництво «Юстініан», 2008. 872 с

[2] Бервено С. М. Проблеми договірного права України: монографія. К.: Юрінком Інтер, 2006. 392 с.

[3] Господарський процесуальний кодекс України. Науково-практичний коментар / за ред. П.В. Мельник К.: Центр учбової літератури, 2012. 364 с. 
[4] Звеков В. П. Международное частное право: курс лекций. М.: Изд. группа НОРМА; ИНФРА. 1999. 667 с.

[5] Конвенція про правову допомогу і правові відносини у цивільних, сімейних і кримінальних справах від 22.01.1993 [Електронний ресурс]. Режим доступу: http://zakon3.rada.gov.ua/laws/show/997_009/parao110\#o110

[6] Конвенція про правову допомогу та правові відносини у цивільних, сімейних та кримінальних справах від 07.10.2002 [Електронний ресурс]. Режим доступу: http://zakon3.rada.gov.ua/laws/show/997_619/parao297\#o297

[7] Міжнародне приватне право: навч. посіб. / за заг. ред.: В. М. Гайворонський, В. П. Жушман. К.: Юрінком Інтер, 2007. 366 с

[8] Про деякі питання практики розгляду справ за участю іноземних підприємств і організацій: Роз'яснення Вищого господарського суду України від 31.05.2002 № 04-5/608 [Електронний ресурс]. Режим доступу: http://zakon0.rada.gov.ua/laws/show/v_608600-02

[9] Угода про порядок вирішення спорів, пов'язаних із здійсненням господарської діяльності від 1992 року [Електронний ресурс]. Режим доступу: http://zakon0.rada.gov.ua/laws/show/997_076

[10] Цірат Г.А. Міжнародна підсудність / Г.А. Цірат // Актуальні проблеми міжнародних відносин. № 84. Ч II. 2009. С. 151-160

[11] Щодо застосування конвенцій про правову допомогу та правові відносини у цивільних, сімейних та кримінальних справах: Лист Міністерства юстиції України від 21.01.2006 № 26-53/7 [Електронний ресурс]. Режим доступу: http://zakon3.rada.gov.ua/laws/show/v53_7323-06 


\section{THE METHODOLOGICAL BASIS LAW-INTERPRET ACTIVITY}

\section{E. Terekhov ${ }^{1}$}

\section{Abstract}

Law-interpret activities are carried out with the use of certain methods to analyze its processes. In the present article examines the key methods law-interpret activities. Given their characteristics. Examples are given.

Keywords: legal activity, law-interpret activity, interpretation of law, interpretative act.

In the context of globalization following the complexity of the socio-economic and political life is complicated and the legal society. A special place it occupies a legal activity, which in the most general terms, is divided into legislative, lawinterpret enforcement. Of all the varieties of legal activity, law-interpret its kind in the domestic legal science studied less than others.

The full study law-interpret activity is impossible without the determination of its concepts. Unfortunately, modern jurisprudence does not contain a single term «law-interpret activity», causing confusion in the system of legal activity.

Law-interpret activity as a mechanism of work of state-government entities to disclose the meaning of the law, implemented within certain limits (limits), ending with the publication of acts of interpretation, causing legal consequences of the subjects of law has at its disposal a powerful methodological framework that allows achieving the set goals.

Legal regulation is necessary to ensure that relations in society proceeded in accordance with the law, and this is achieved, inter alia, by the clarity of the meaning of the law. And if the legislator can afford a favor by giving the rule of law double meaning, the subjects law-interpret activities that can not afford. However, they use different methods to uncover the meaning of the law.

Key methods law-interpret activities are the static and dynamic.

The essence of the static method law-interpret activity is that the meaning of the rule of law is revealed by its literal interpretation, without the use of historical, social, economic and other changes that occur (occurred) in modern society. The rule of law is interpreted in the same sense that was given to her at the time of the adoption of a normative legal act and will be put into it until it is canceled.

December 12, 1993 was adopted by the fundamental law of the Russian Federation, p. 3 art. 32 which suggests that they have no right to elect and be elected citizens who are in prison upon conviction [1]. The European Court of Human Rights, regarding the 2013 complaint on the case «Anchugov and Gladkov against Russia» [2] came to the conclusion that the meaning of h. 3 tbsp. 32 of the Constitution of the Russian Federation contradicts the sense of individual articles

${ }^{1}$ Evgeniy Terekhov, Candidate of law, Assistant professor of the chair of State and legal disciplines Balakovo branch of the Saratov State Academy of Law, Russia. 
European Convention on Human Rights. The Constitutional Court of the Russian Federation in 2016, disagreeing with the findings of the ECHR, has issued interpretative act, which indicated that h. 3 tbsp. 32 of the Constitution of the Russian Federation must be interpreted in the sense that was given to her at the time of the adoption of the Constitution of Russia, namely: "The possibility of restrictions on the right to participate in the elections, including the right to vote derives from the constitutional nature of the voting rights, which embodies the unity of subjective electoral powers citizen and general (collective) interest in the formation of legitimate bodies of popular representation on the basis of free elections. Article 32 (part 3) of the Constitution of the Russian Federation is uniquely captures what categories of citizens do not have the right to elect or be elected, though the composition of these categories in any case, in its final form is determined by the federal legislator, since it was he who on the basis of constitutional provisions stipulates that from itself is deprivation of liberty (imprisonment) as a special form of criminal punishment, which is expressed in the contents of the convict in the special prison - in contrast to other types of legal deprivation of liberty in the broadest sense» [3].

Dynamic method law-interpret activity is a complete contrast to the static method and its essence lies in the fact that the rule of law should be interpreted taking into account the historical, social, economic and cultural changes that have occurred since the adoption of the normative legal act to date. This method gives the rule of law the law of life, adjusting its meaning in the direction of the need for legal regulation and legal activities.

Not so long ago the subject of consideration by the Constitutional Court was to check the constitutionality of which has not entered into force of an international treaty between the Russian Federation and the Republic of Crimea on the adoption of the Russian Republic of Crimea and education as part of the new Russian subjects.

The Constitutional Court of the Russian Federation explained that the said agreement is not contrary to the Constitution of the Russian Federation from the standpoint of the principle of separation of powers and the distribution of powers between the federal bodies of state power, meets all the requirements of the current legislation requirements to such documents mind [4].

The Court in this case carried out law-interpret activities:

- taking into account the historical criterion - Crimea region geographically was part of the RSFSR, but was transferred to the Ukrainian Soviet Socialist Republic of 9 March 1954;

taking into account the social and cultural criteria - the vast majority of persons living in the territory of the Republic of Crimea is Russian-speaking citizens, the number of which in 2014 amounted to $65.2 \%$ [5].

Depending on the availability of interest is isolated method of objectivism and subjectivism law-interpret activities [6, p. 196].

Method objective interpretation of the characteristic of the person who interprets the law without regard to their social and psychological units. This may be a court, which acts in accordance with the principles of impartiality and independence. 
The method is characterized by subjective interpretation for the person who interprets the law in order to derive any benefit for himself. This may be a prosecutor in charge of the public prosecution.

In one of the many interviews, V.D. Zorkin noted that acts of interpretation of the law of the Constitutional Court, in contrast to other legal acts of the judiciary, «determine the fate of the law, and, therefore, arise on its basis the set of legal, contracts, law enforcement acts etc.» [7]. This method is imperative and manifest in law-interpret activity of the Constitutional Court, which allows us to consider a formal judicial interpretation as a function of causing the need to respond to the court made by the legal acts.

Thus it becomes apparent that the methods law-interpret activities not only enable it to achieve its objectives, but their clever use may adjust the law-making and law-enforcement practice in the right direction.

\section{References:}

[1] The Constitution of the Russian Federation: adopted by national referendum 12 December 1993 (with changes) // Russian newspaper. 1993, 25 December.

[2] ECHR Decision from 04.07.2013 г. «Case «Anchugov and Gladkov against Russia» (Complaint № 11157/04, 15162/05)» // The Human Rights Court Bulletin. 2014. № 2.

[3] Decision of the Constitutional Court of the Russian Federation from 19.04.2016 № $12-\mathrm{P}$ «In the case of the resolution of the question of the possibility of execution in accordance with the Constitution of the Russian Federation, the European Court of Human Rights ruling from 4.07.2013 from Case «Anchugov and Gladkov against Russia» in connection with request of the Ministry of Justice Russia» // www.pravo.gov.ru (date of the application 15.01.2017).

[4] Decision of the Constitutional Court of the Russian Federation from 19.03.2014 № 6$\mathrm{P}$ «In the case of check of constitutionality has not entered into force of an international treaty between the Russian Federation and the Republic of Crimea on the adoption of the Russian Federation Republic of Crimea and the formation of the Russian Federation of new subjects» // Russian newspaper. 2014. 20 March.

[5] The population of the Crimea and Sevastopol: strength, ethnic composition // www.statdata.ru (date of the application 15.01.2017).

[6] Borulenkov Y.P. Methodological status of hermeneutics in legal knowledge // Legal Science: History and Present. 2015. № 7. 189-199 p.

[7] Interview with Valery Zorkin // www.viperson.ru (date of the application 17.02.2017 г.). 


\title{
EUTHANASIA IN MODERN WORLD
}

\section{K. Vladimirova ${ }^{1}$, A. Galkina ${ }^{2}$, I. Kondrashova ${ }^{3}$}

\begin{abstract}
The phenomenon of euthanasia is a reason for reflection of the public legal consciousness of the population. Due to the fact that human life is the main value of modern civilization, the problem of euthanasia has acquired a different path on demand. The value of human life against towards all legal and moral realities creates some socio-legal problems, in a particular, the aspect affecting the right to life. In this article, we have tried to disclose the essence of euthanizing and to consider the arguments "for" and "against".
\end{abstract}

Keywords: euthanasia, active euthanasia, passive euthanasia, euthanasia problems.

Among a set of medical, legal, religious problems the important place is taken by euthanasia problem. This problem is connected with the most important thing that the person has, with his life. So we have decided to reveal the essence of euthanasia, consider the arguments "for" and "against", to identify the moral and legal aspects of the problem and to find out the place it occupies in the modern world.

For a start, we will address to this word's etymology. In "The New Dictionary of Foreign Words" euthanasia is considered as "assistance to offensive of death and by that to the termination of sufferings of incurably sick people (from their consent or with the consent of their relatives or trustees at impossibility of decision-making by the being patients' unconscious, mentally incomplete, etc.)"[1, 770]. "The Big Legal Dictionary" defines euthanasia as "satisfaction of a request of the patient for acceleration of his death with actions or agents, including the termination of artificial measures for maintenance of life" $[2,685]$. It is worth noticing that the given dictionary's interpretation, in our opinion, does not clear up a question of what euthanasia actually is and what spheres of possible usage of this term.

In real life the manifestation of euthanasia is very diverse and often does not fit into existing ideas about it. It is also true that the diversity of views about the nature of euthanasia can be explained by the multidimensional nature of this phenomenon, its insufficient study.

\footnotetext{
${ }^{1}$ Kristina Vladimirova, Student of Law Institute, South Ural State University (National Research University), Chelyabinsk, Russia.

${ }^{2}$ Anastasiya Galkina, Student of Law Institute, South Ural State University (National Research University), Chelyabinsk, Russia.

3Inna Kondrashova, Candidate of Pedagogical Sciences, Associate Professor, South Ural State University (National Research University), Chelyabinsk, Russia.
} 
Let's consider the term "euthanasia" from the scientific point of view. People distinguish a passive and an active euthanasia. The passive euthanasia is a refusal of the treatment supporting life when it stops, or doesn't begin at all. The passive euthanasia is quite often met in medical practice. In this case at the request of the patient even intravenous injections and artificial nutrition have to be stopped, at the same time it is impossible to undertake attempts of revival of the person if his heart or lungs have ceased to work. If the patient can be discharged from hospital to die at home, he shouldn't be prevented from doing that $[3,189]$.

The active euthanasia is a deliberate action with the purpose to interrupt the patient's life, for example by an injection causing death. People distinguish such forms of active euthanasia as murder out of compassion, a voluntary active euthanasia and suicide with a doctor's help. In the second and third cases, the determining factor is consent of the patient. In the second case the doctor at the request of the patient does him a lethal injection, in the third one the doctor gives patient some medicine which allows him to commit suicide. Though in the majority of the countries, including Russia, active euthanasia is forbidden by the law, it causes many medical and philosophical debates [4].

Opinions about the issue of euthanasia has been divided into "for" and "against". One of the supporters of euthanasia is the resigned Professor of Medical Ethics and the former member of the Commission on Ethics of the British Medical Association Len Doyal. He says: "Physicians can not recognize it and give the actions for "relief of sufferings of patients", however, refusal of further support of biological existence of the unconscious patients from the moral point of view is equivalent to an active euthanasia". He also adds: "If the doctors are able to make a decision on inexpediency of further life support incapacitated patients because they believe that they have no reason to live, why without any reason to postpone their death?". Another supporter of euthanasia is the executive director of the English public organization "Dignity in Dying" Deborah Ennets. She says: "The organization considers that decisions on the termination of life and treatment have to be based on conscious will of incurably sick people. The people, who are afraid to lose capacity in the future, can provide execution of the will, having made the corresponding will".

A negative assessment of euthanasia is given by the German doctor and the theologian Manfred Lyutts: "The fact that today people in polls support euthanasia, is explained only by their pavor in the future to depend on tubes and droppers. Of course, they can be understood, but nevertheless it is necessary to keep a taboo on killing. Elimination of a taboo can cause the hardest consequences for society. The fear of loneliness of death and fear of pain is very big, but by means of the professional anesthetizing therapy it is possible to cope practically with any pain".

We consider that the question of euthanasia is rather difficult and ambiguous. Therefore, it is impossible to draw a conclusion on the ban of euthanasia or its encouragement precisely. 
Speaking about euthanasia raises two questions - moral ("What can we say about the nature of man who commits such acts?") and legal ("Should such actions be prohibited by law?"). Some claim that though the euthanasia is immoral, it shouldn't be forbidden in a legislative order. There are two opinions which are usually given as arguments against application of criminal sanctions: first, too high costs for implementation of these sanctions in life, and secondly, the prospect of disobedience is so broad that it already undermines general respect for the law - apparently, in this case aren't applicable.

Others claim that though euthanasia not in all cases is wrong, it shouldn't be resolved by the law. One of options of this argument claims that euthanasia it is moral is admissible only in rare instances. But even there it should be forbidden as it is very easy to abuse this practice therefore legalization of an euthanasia will do more harm, than good. Other option says that legalization puts elderly people in the difficult choice: either to continue to live, or to die. This situation in which nobody can be put.

More general was the opinion that the euthanasia from the moral point of view is admissible only in exceptional cases, but in such cases it is necessary to legalize it. Recent legislative initiatives in those countries where it is permitted, resolve an euthanasia only in exceptional cases.

Officially the euthanasia is resolved in such countries is Belgium, the Netherlands, Holland, Switzerland, some states the USA, Luxembourg and Canada. But it should be noted that laws and policies should be set three conditions:

1) the euthanasia has to be voluntary;

2) only the doctor can give help or carry out euthanasia;

3 ) the patient's state has to be unsatisfactory from the medical point of view.

Naturally, in each country there is the option of procedural ways of protection against abuse of this right.

Thus, summing up the result of our work, it would be desirable to note the following. The problems bound to euthanasia concern legislators and the public of many modern states, there are a subject of discussion and researches of experts of different areas. It is necessary to understand that any right including criminal, can't provide all special cases. The decisions made by medicine can't be replaced by legal. Especially it concerns human life. But such problem as euthanasia exists, and it requires the solution including legal. In our opinion the active euthanasia, at least, presently, has no right for life as it hides in itself the mass of opportunities for the wrong use of the act of euthanasia.

In our society the voluntary and passive euthanasia can be the only way of implication of an euthanasia. It is necessary to formulate accurately and consciously legislative rule according to which the patient has full authority to know the diagnosis of the disease, her possible consequences, degree of risk of a failure at refusal of treatment, degree of hope for recovery. If the patient is in a vegetative state, the irreversibility of that state has to be defined. In our opinion, the issue of an euthanasia should be resolved in the presence of the most sick or his representative having the will documented in advance. If it isn't possible, for a number of reasons, all the same, the issue of killing shouldn't be resolved by one person, and for example a consultation of doctors. Also it is necessary to prevent 
physical suffering of the dying, even by using those means, which in other cases would be contraindicated. Only in this case death, but already at will of the patient as a result is possible.

References:

[1] Zakharenko E. N., Komarov L. N, Nechayeva I. V. New Dictionary of foreign Words. Moscow, 2003. 770 p.

[2] Sukharev A. Ya., Krutskikh B. E. The Big Legal Dictionary. Moscow, 2002. 685 p.

[3] Paul Kurtz, Forbidden Fruit: The Ethics of Humanism (Amherst, N.Y.: Prometheus Books, 1988).

[4] Andreyeva A. A., Prikhodko of V. V. Problem of an euthanizing in modern society, BMIK. 2012. no. 11. 


\title{
PROBLEMS OF SMALL BUSINESS DEVELOPMENT IN RUSSIA
}

\author{
E. Dmitrieva ${ }^{1}$, I. Kondrashova $^{2}$
}

\section{Abstract}

This article focuses on the issue of support of small entrepreneurship in Russia. Currently, the Russian government creates favorable conditions for this. You must provide logistical, financial and resource base for the productive development of business in Russia.

Keywords: small business, the market economy, government, GDP, investment, capital, legislation, Russia, logistics, lending, state support.

A person of any developed country is determined by the large enterprises, and the presence of large capital has a significant impact on the level of scientific and technical potential and production capacities. Small business is also an important component of a developed market system. It represents the most flexible, dynamic and mass form of organization enterprises. It is in this sector where the bulk of national resources is created and is circulated. These resources are the breeding ground for the development of the economy of any country.

High level of development of small entrepreneurship is a necessary condition for the successful functioning of a market economy. Small business in developed countries in many respects defines rates of economic growth, structure and quality of gross national product, shaping it in the volume of $40-50 \%$ and in some industries, up to $70-80 \%$ [3].

In our country there are large reserves for small business growth. The rate of growth of this sector of economic activity in the coming years in Russia will depend on the economy as a whole, increasing its effectiveness, as well as the welfare of the people of Russia.

Small business plays an important role in the development of the economy of many countries. In the European Community (EC), USA and Japan small and medium-sized enterprises account for about $50 \%$ of total employment. Their share in GDP exceeds 50\%. The development of small businesses in Russia is significantly lagging behind in comparison to some developed countries. The most important part of total GDP share of small and medium enterprises in Russia is only $10-11 \%$, while in developed countries it is $50-60 \%$. Unfortunately, in recent years a significant change in the situation has not happened. Small businesses in Russia in their activities face great difficulties. The main problem is the insufficient resource base either logistical or financial. Practically it is creating a new sector of the economy, which for decades we have substantially absent. This, in

1Elena Dmitrieva, Applicant for a Master's Degree, South Ural State University, Chelyabinsk, Russia.

${ }^{2}$ Inna Kondrashova, Candidate of Pedagogical Sciences, Associate Professor, South Ural State University, Chelyabinsk, Russia. 
particular, means also a lack of trained entrepreneurs. The bulk of the population, who lived from payday to payday, can be formed reserve funds necessary to start their own business. These funds must be found now. It is clear that the very tense state budget can not be the source. The main hope is the credit. But they are small and very difficult to achieve with constant and increasing inflation [2].

The situation is unlikely to change seriously in the right direction, if it does not move at last from words to deeds in public support for a constructive small business. In the perspective of 2016-2017, reasons to count on the state support of small entrepreneurship, which will be expressed in the form of cash grants, training and free of charge, internships, preferential leasing, business incubator (possibility to rent a good office for a nominal fee), as well as grants, etc. We can only hope for the significant increase available for this logistical and financial resources.

According to the statistics of small businesses, almost $60 \%$ of investments into the fixed capital invested in the active part of fixed assets - machines, equipment, tools, implements, whereas in all investments in fixed capital for these fixed assets was $44 \%$. This suggests that small business enterprises have equal conditions for better, more efficient use of investment, as machinery and equipment, not buildings, create real products. Meanwhile, the proportion of investment in fixed capital of small businesses in total investment in fixed capital is decreasing from year to year. With a corresponding increase in investment in fixed capital of these companies, they could significantly increase their production volumes. These data also indicate that at relatively low investment, small businesses will bring greater returns than large ones.

Mechanisms of preferential crediting, taxation, different kinds of benefits, including those associated with foreign trade activities should be established. Their meaning is to meet the needs of people while creating conditions for sustainable deployment of entrepreneurship.

The next problem is the legislative base, which can now rely on small business. As it put it mildly, imperfect, and in many very significant provisions is absent. There are many legal documents anyhow regulating small business; the difficulty lies in the fact that, firstly, there is a free single legislative framework for today's activities of the domestic small businesses, and secondly, the existing scattered establishment are brought to life not completely.

Currently small business is in conditions very remote from those that should be inherent in a market economy. There is no system of conducting a deep analysis of the activities of small business, there is no proper consideration of the results of their work, virtually no reporting on those indicators that give the right to these enterprises to use the tax benefits.

The logistics of small businesses is insufficient. Machines, equipment and devices intended for such enterprises, taking account of their specificity, do not exist. There is a limited access to high technology, since their sale requires a significant one-off financial costs. A difficult problem is social protection of entrepreneurial activity. It is known that previously existed on the basis of the distribution of public funds, the system of social guarantees and social security in the 
current environment was almost undermined. Requires, in fact, to build this system again in relation to the whole of society, and in relation to the entrepreneurs - a new social layer - even more so. There is also the issue of lending to small businesses [4].

You can select multiple reasons, which most displease small businesses with loan quality:

Firstly, it is the lack of incentives in lending to enterprises operating with a certain Bank for a long time.

Secondly, the enterprises of small and medium businesses are dissatisfied with the necessity of preparation of a large package of documents and the length of terms of consideration of their applications.

Thirdly, the enterprises of small and medium businesses are dissatisfied with the quality of banking services. First of all, it concerns the speed and terms of service, the cost of services.

All these measures will improve the overall small business lending.

In general, the idea of ranking factors that hinder business development in Russia, gives the following:

-Taxation 62,67

-Administrative barriers 60,89

-Corruption is 52,22

-General political and economic instability 50,09

-The underdevelopment of the judicial system 46,89

-Lack of qualified personnel 45,83

-The lack of investment resources 38,12

-Depreciation of fixed assets of enterprises 34,67

The underdevelopment and deterioration of the infrastructure 34,22

The low effective demand for products and services 25,78 [1].

The extent of small business development in Russia and its contribution to economic recovery today is clearly insufficient. In Russia there are different organizational forms of state support and protection of the interests of companies in this sector. There have been created The Association of the Enterprises of Small Business, Department of development and support of small entrepreneurship, various funds for the development and support of small businesses. However, as a rule, numerous funds of support for small businesses are concerned about their own problems and do not really help small business.

In Russia at present, the level of development of small and medium business clearly does not correspond to the current needs of the economy, nor even tomorrow's demands of the globalizing world market. And not to stay in the role of catch-up forever, we need in the near future to eliminate the risk of distortion in the field of entrepreneurship, the business potential is realized so far only partially, and its development is hampered by numerous problems, the solution of which depends not only the fate of small businesses, but market reforms in General.

In conclusion it should be said that small business is the driving force of any economy, contributing to the attraction and redistribution of investments in the 
most efficient and, most importantly, in social sphere. The development of various forms of state support of small business allows us to hope that in the future this sector will develop in the country. But this requires clear and effective state policy aimed at support and development of small businesses.

\section{References}

[1] Afanasiev V.O. Small business: problems of formation. // "Russian economic journal".2007. No. 8. pp. 6-23.

[2] Metelkin A.E. Small business Enterprises: current state and development trends / A.E. Metelkin // Young scientist. 2012. № 10. p. 129-132;

[3] Mukhametdinov R. F. Current state of small business in Russia / R.F. Mukhametdinov, R. R. Dadajanova // Young scientist. 2013. № 5. p. 359-360;

[4] The President's Address to the Federal Assembly, 04.12.2014 // ITAR-TASS; 


\title{
PEDAGOGY
}

\section{INTRODUCTION OF INNOVATIVE TECHNOLOGIES IN THE PROCESS OF LEARNING A FOREIGN LANGUAGE IN HIGH SCHOOL}

\author{
U. Yuldasheva ${ }^{1}$, Z. Akhmedova ${ }^{2}$
}

\begin{abstract}
The article deals with the active introduction of innovative technologies in education, the use of technological possibilities of modern means of communication, the use of ICT in the process of learning a foreign language, which contributes to improving the linguistic and intercultural competencies of students; of the forms of work with computer tutorials on student-oriented technologies, tools and techniques of foreign language teaching, the essence of the interactive learning, the effectiveness of the Internet in the formation of the skills of colloquial speech.
\end{abstract}

Keywords: innovative technologies, linguistic and intercultural competence, interactive learning

Обучение иностранному языку в неязыковом вузе рассматривается как обязательный компонент профессиональной подготовки специалиста любого профиля, а владение иностранным языком как фактор, повышающий степень востребованности специалиста на рынке труда и одновременно как один из показателей уровня образованности современного человека.

Стоит отметить, что специализированные вузы - это учебные заведения, готовящие специалистов в разных профессиональных областях (экономисты, юристы, менеджеры, политологи и др.) с углубленным изучением иностранных языков. В данной связи необходимо подчеркнуть, что иностранный язык не является их специальностью, а средством осуществления профессиональной деятельности.

Студентам должны быть созданы благоприятные условия для использования технологических возможностей современных компьютеров и средств связи, для поиска и получения информации, развития познавательных и коммуникативных способностей, умения оперативно принимать решения в сложных ситуациях. Все это становится возможным с помощью современных информационных (ИТО) и коммуникационных технологий обучения.

1Umida Yuldasheva, a teacher of foreign languages department, Tashkent Financial Institute, Uzbekistan.

2Zulaikha Akhmedova, assistant of the department of foreign languages, Tashkent Financial Institute, Uzbekistan. 
У студентов развивается и совершенствуется умение работать в команде, такой принцип совместного обучения содействует развитию творческого начала и росту академического потенциала. Студенты отвыкают от навязанного им «зазубривания», им приходится находить оригинальные решения при возникающих непривычных ситуациях, что положительно влияет на формирование личности.

Информационно-коммуникативные технологии находят все большее применение в организации учебного процесса, позволяют продуктивно рассмотреть все возможные аспекты (от лингвистического до культуроведческого), совершенствуют иноязычную речевую деятельность. Их использование способствует совершенствованию лингвистической и межкультурной компетенций студентов, формированию культуры общения в электронной среде, повышению информационной культуры в целом, а также развитию навыков работы на компьютере: поиск, обработка, передача, систематизация информации и презентация результатов научно-исследовательской деятельности студентов [1].

Сегодня новые методики с использованием Интернет - ресурсов противопоставляются традиционному обучению иностранным языкам. Чтобы научить общению на иностранном языке, нужно создать реальные, настоящие жизненные ситуации (т.е. то, что называется принципом аутентичности общения), которые будут стимулировать изучение материала и вырабатывать адекватное поведение. Эту ошибку пытаются исправить новые технологии, в частности Интернет [2].

Формы работы с компьютерными обучающими программами на уроках иностранного языка включают: изучение лексики; отработку произношения; обучение диалогической и монологической речи; обучение письму; отработку грамматических явлений. Студенты могут принимать участие в тестировании, в викторинах, конкурсах, олимпиадах, проводимых по сети Интернет, переписываться со сверстниками из других стран, участвовать в чатах, видеоконференциях и т.д.

Интернет помогает в формировании умений и навыков разговорной речи, а также в обучении лексике и грамматике, обеспечивая подлинную заинтересованность и, следовательно, эффективность. Более того, Интернет развивает навыки, важные не только для иностранного языка. Это, прежде всего, связано с мыслительными операциями: анализа, синтеза, абстрагирования, идентификации, сравнения, сопоставления, вербального и смыслового прогнозирования и упреждения и т.д.

Личностно-ориентированные технологии представлены технологиями дифференциации и индивидуализации обучения, проектными технологиями и т.д. Основными формами использования информационных технологий являются следующие:

1) мультимедиауроки, которые проводятся на основе компьютерных обучающих программ;

2) уроки на основе авторских компьютерных презентаций в ходе лекций, семинаров, лабораторных работ, докладов студентов. Так, с помощью компьютерной программы PowerPoint преподаватели организуют серии 
мультимедийных уроков, учебных модулей, электронных учебных пособий, которые позволяют интегрировать аудиовизуальную информацию, представленную в различной форме - графика, слайды, текст, видеофильм и т.д.;

3) тестирование на компьютерах (особенно при подведении итогового контроля);

4) телекоммуникационные проекты, работа с аудио- и видеоресурсами в режиме онлайн;

5) лингафонные устройства, которые включают в себя преподавательскую консоль и рабочие места студентов, а также оборудование по одной из следующих схем: аудиопассивной, аудиоактивной или аудиокомпаративной.

Все это направлено на создание иноязычной среды в процессе обучения иностранным языкам, для достижения чего и используются технические средства обучения. Так, например, компьютерные обучающие программы на занятиях по иностранному языку позволяют осуществлять следующие формы работы: отработка произношения; работа над грамматическим и лексическим материалом, разговорной речью.

Средства телекоммуникации, включающие электронную почту, глобальную, региональные и локальные сети связи и обмена данными, открывают перед обучаемыми и педагогами широкие возможности: оперативную передачу на любые расстояния информации любого вида и объема; доступ к различным источникам информации; интерактивность и обратную связь; организацию совместных телекоммуникационных проектов.

Выбранные приемы и методы обучения иностранному языку призваны решать следующие задачи:

- Создать условия для формирования нравственных понятий и убеждений

- Создать условия для развития творческих и мыслительных способностей

Раскрыть возможности использования межпредметных знаний для интеллектуального развития. Суть интерактивного обучения состоит в том, что учебный процесс организован таким образом, что практически все учащиеся оказываются вовлеченными в процесс познания, они имеют возможность понимать и рефлектировать по поводу того, что они знают и думают.

B XXI веке общество предъявляет все более высокие требования к практическому владению английским языком в повседневном общении и профессиональной сфере. Объемы информации растут, и часто рутинные способы ее передачи, хранения и обработки являются неэффективными. Использование информационных технологий раскрывает огромные возможности компьютера как средства обучения. 
References:

[1] Владимирова Л.П. Интернет на уроках иностранного языка. ИЯШ. №3. 2002. С 33-41.

[2] Сиразеева А.Ф., Валеева Л.А., Морозова А.Ф. Инновационные технологии обучения иностранному языку в вузе // Современные проблемы науки и образования. 2015. № 3.23 с.

[3] Преподавание иностранного языка в XXI веке: проблемы и перспективы: Материалы Всерос. науч.-практ. конф. М., 1998. 120 с. 


\section{INDIVIDUALLY-DIFFERENTIATED APPROACH IN TEACHING A FOREIGN LANGUAGE IN NOT LANGUAGE HIGH SCHOOL}

\section{T. Islamova ${ }^{1}$}

\section{Abstract}

This article discusses a number of issues differentiated and individual approaches to teaching foreign languages, about the individual characteristics of students, on the approaches to the individualization of the educational process of technology tiered (differentiated) learning about the development model of foreign language.

Keywords: differentiated approach, multilevel training, personal identity.

Традиционно обучение иностранному языку в неязыковом вузе было ориентировано на чтение, понимание и перевод специальных текстов, а также изучение проблем синтаксиса научного стиля. Сейчас необходимо думать о перемещении акцента в обучении на развитие навыков речевого общения на профессиональные темы и ведения научных дискуссий, тем более, что работа над ними не мешает развитию навыков, умений и знаний, так как на них базируется. Вместе с тем ряд вопросов дифференцированного и индивидуального подходов в обучении иностранным языкам остаются по сей день спорным и недостаточно разработанным. К ним можно отнести неупорядочение терминологии, связанной с дифференцированным и индивидуальным подходами, отсутствие классификации индивидуализированных мер - заданий, соотносимой с типологией студентов, определение оптимального соотношения между индивидуальными особенностями и спецификой компонентов объекта обучения иностранному языку, выявление потенциальных возможностей студентов к учению и создание педагогических условий для развития психических аспектов личности на уроках иностранного языка и др.Одной из актуальных проблем преподавания иностранного языка является дифференцированный подход в обучении.

Технология разноуровневого (дифференцированного) обучения предполагает осуществление познавательной деятельности студентов с учётом их индивидуальных способностей, возможностей и интересов, поощряя их реализовывать свой творческий потенциал. Создание и использование диагностических тестов является неотъемлемой частью данной технологии.

Дифференциация в обучении теснейшим образом связана с индивидуальными особенностями обучаемых. Для положительного решения этой проблемы крайне важно учитывать личные качества каждого студента.

${ }^{1}$ Tahira Islamova, senior teacher of foreign language, Tashkent Financial Institute, Uzbekistan. 
Игнорируя личную индивидуальность, отрывая речевые действия от реальных чувств, мыслей, интересов, т.е. от практического отношения личности к действительности, мы заставляем студентов рассматривать язык лишь как некую формализованную систему, а не как орудие общения.

Личная индивидуальность обучаемых определяет: 1) контекст деятельности обучаемого; 2) жизненный опыт; 3) сферу интересов, желаний, склонностей; 4) мировоззрение; 5) эмоционально-чувственную сферу; 6) статус личности в коллективе.

В рамках традиционных двухчасовых занятий студентам не хватает учебного времени для освоения материала на уровне творческого применения. Специалист в современных условиях должен за короткое время качественно осваивать новые технологии и новое содержание профессиональной деятельности. Поэтому уже в стенах учебного заведения его необходимо подготовить к работе в условиях концентрации времени и усилий. В частности, выработана уровневая модель владения иностранным языком (TOEFL, IELTS, создана концепция образовательного отдела Совета Европы), разработаны личностно-ориентированный подход, концепция о разноуровневом обучении, в большинстве учебных заведений академические группы и подгруппы формируются в зависимости от уровня обученности студентов, группы с одаренными студентами и др. Результаты этих мер положительно сказываются на эффективности обучения. Заинтересованное участие студента в овладении способами обучения и повышение собственной мотивации обеспечивает в дальнейшем повышение уровня самореализации выпускника вуза. Результаты обучения связаны с ожиданиями самого обучающегося, что он будет знать, понимать, уметь делать в конце обучения. Данный подход позволяет индивидуализировать учебный процесс, удовлетворить разносторонние образовательные интересы студентов; развить их интеллектуальный и творческий потенциал; предлагает им совместно с преподавателем выделить объём и содержание учебного материала, который они могут усвоить. Общеизвестно, что контингент изучающих иностранный язык в группе неоднороден. Есть студенты с различными умственными способностями, различными природными данными, разными интересами, различным уровнем владения иноязычной коммуникативной компетенцией. Поэтому задача преподавателя состоит в том, чтобы определить индивидуальные особенности студентов, их языковую подготовленность и организовать на этой основе учебную деятельность по трём режимам: первый режим (начальный уровень) 一 для менее подготовленных студентов, которые условно умеют читать и переводить со словарем; второй режим (средний уровень) 一 для тех, кто умеет читать и переводить со словарем, но не владеет говорением; третий режим (продвинутый уровень) - для тех, кто владеет навыками чтения и говорения на иностранном языке. Так, студент, работающий в первом режиме, осваивает определенный объем материала; студент, работающий во втором режиме, осваивает материал первого режима плюс дополнительный материал; студент, работающий в третьем режиме, осваивает материал двух предыдущих плюс дополнительный материал (задания повышенной 
сложности). При организации работы со студентами по выбранному ими режиму необходимо соблюдать следующие правила:

- студент начинает изучать иностранный язык в вузе с того уровня, с которым пришел после школы;

- учится с той скоростью усвоения материала, на которую способен;

- сам выбирает тот режим работы, который считает для себя наиболее адекватным;

- имеет право в течение всего срока обучения переходить из одного режима в другой;

- работа по циклу считается завершенной, если все запланированные задания выполнены, и студент овладел необходимыми знаниями, умениями и навыками.

Основной формой организации обучения является цикл (6 занятий), в течение которого каждый студент изучает определённый тематический раздел: прочитывает базовый учебный текст, выполняет послетекстовые задания, позволяющие студентам глубже вникнуть в суть отдельных языковых и грамматических явлений и упражнения на развитие коммуникативной компетенции. На основе базового текста студентам предлагается самостоятельно формировать монологическое высказывание по конкретной теме. Для преподавателя здесь есть возможность помочь студентам со слабой языковой подготовкой выбрать из всего текста ту часть информации, которой им по силам овладеть на должном уровне. Предполагается и обратный процесс: знакомство с дополнительными материалами и текстами может стать для хорошо подготовленного студента поводом расширить содержание базового текста, и даже стать основой для творческого проекта. В конце каждого цикла проводится минизачет, на котором определяется готовность студента перейти к работе над следующим циклом.

Изучение интересов и склонностей студентов, их учебных возможностей, а также анализ перспектив развития этих возможностей должны послужить исходным моментом в дифференцированном подходе к обучению иностранному языку. Проблема ликвидации разрыва между так называемыми сильными, средними и слабыми студентами может быть решена только при правильном использовании индивидуальной, парной, групповой и коллективной форм работы. Для этого необходимы специальные организационно-методические приемы, которые преподаватель использует на занятии для того, чтобы обучать всех, создавая одновременно наиболее благоприятные условия для обучения каждого. Большое значение играет и очередность опроса. Сначала нужно обращаться к хорошо и среднеуспевающим студентам, а затем к слабо подготовленным студентам. Слабые студенты выигрывают тем, что получают образец правильного ответа сильных студентов. Это помогает им правильно употребить и запомнить языковой материал.

Таким образом, дифференцированный подход к изучению иностранного языка способствует развитию у студентов коммуникативной компетенции, повышению эффективности обучения. 
References:

[1] Рогова В.Г. Технология обучения иностранным языкам ИЯШ. 1976. №2.

[2] http://www.hetoday.org/arxiv/VOS/9_2009/59_63.pdf

[3] Леонтьев А.А «Язык и речевая деятельность в общей и педагогической психологии» М.: Издาво Московского психологолсоциального института; Воронеж: Изд ᄀво НПО «МОДЕК», 2001. С. 332-347 


\section{DEVELOPMENT DISCURSIVE COMPETENCE OF STUDENTS OF NOT} LANGUAGE HIGH SCHOOLS IN THE STUDY OF FOREIGN LANGUAGES

\section{Madalaieva ${ }^{1}$}

\section{Abstract}

The article deals with the development of discursive competence, on the causes of certain difficulties in the educational and professional activities related to communication in a foreign language, about the formation of a professional discourse, in which the specialist carries out his professional activities.

Keywords: discursive competence, professional discourse, professionally-oriented education.

Противоречие между высокими требованиями к подготовке современных компетентных специалистов и сложившимися в силу объективных причин условиями обучения иностранному языку в неязыковом вузе приводит к тому, что коммуникативный компонент в структуре базовых компетенций не получает своего должного развития. Преодоление данного противоречия возможно путем развития дискурсивной компетенции, которая подразумевает соединение знаний норм и правил языка со способами формулирования мысли в соответствии с реальной ситуацией общения. В лингвистике понятие «дискурс» определяется через понятие «текст» (Ван Дейк), при этом текст часто рассматривается как часть дискурса или его базовая единица. Дискурс всегда является текстом, но не наоборот. Существует множество определений дискурса. Приведем одно из них: дискурс - это «совокупность всего говоримого и понимаемого в определенной конкретной обстановке в ту или иную эпоху жизни данной общественной группы» [1].

Тем не менее, практика работы неязыковых вузов свидетельствует о сравнительно низком уровне дискурсивной компетенции студентов, что служит причиной определенных затруднений в учебной и профессиональной деятельности, связанной с общением на иностранном языке или извлечением информации из иноязычных источников. Это проявляется в подборе языковых средств, не соответствующих контексту общения; в выборе речевых и поведенческих реакций и стратегий, не адекватных коммуникативной ситуации; в неспособности достичь целей коммуникативного акта. А. А. Кибрик определяет дискурс как процесс языковой коммуникации, в результате которой порождается текст. Он считает, что дискурс можно рассматривать и как разворачивающийся во времени процесс, и как структурный объект. «Дискурс - это максимально широкий термин, включающий все формы использования языка» [3]

${ }^{1}$ Dilyafruz Madalaieva, Senior Lecturer, Department of Foreign Languages, Tashkent Financial Institute, Uzbekistan. 
Тогда термин дискурсивная компетенция может быть определен как способность порождать и воспринимать дискурс, т. е. интерпретировать и использовать формы слов и их значения для порождения текстов сообразно среде коммуникации, демонстрировать владение навыками организации языкового материала в связный текст, и способность к декодированию речевых интенций собеседника.

В блоке программы обучения студентов неязыковых факультетов иностранному языку для общих целей конкретизирован перечень тем, целью изучения которых является развитие функционально-коммуникативных умений в рамках учебно-познавательной, бытовой и социально-культурной сфер общения.

Сформированная иноязычная коммуникативная компетенция в значительной мере определяет эффективность коммуникации будущих выпускников неязыковых факультетов с зарубежными партнерами в различных областях культурной, бытовой, профессиональной и научной деятельности; открывает возможности для развития информационной культуры и самосовершенствования человека.

Приступая к обучению в высшей школе, студент сталкивается с профессиональным дискурсом. Профессиональный дискурс - это профессиональное, правовое, языковое и социальное поле, в котором специалист осуществляет свою профессиональную деятельность, обмениваясь информацией с другими коммуникантами.

С лингвистической точки зрения, профессиональный дискурс имеет свое особое оформление, выраженное, как правило, в лексике и стилистике речи. Например, профессиональный дискурс экономистов не только содержит термины и понятия, понимание которых обусловлено наличием фоновых знаний в той или области человеческой деятельности, но и такие нехарактерные для других видов дискурса особенности, как большое количество формул, графиков, расчетов, диаграмм. Поэтому особенно важным фактором на этапе введения в профессиональный языковой дискурс видится опора на межпредметные связи, выстраивание учебного плана по иностранному языку и профильным предметам в такой последовательности, которая позволяет студентам адекватно воспринимать информацию, предъявляемую на иностранном языке. Практический опыт преподавания иностранного языка для экономистов показывает, что ранняя языковая профессионализация, осуществляемая на I-II курсах, не только вводит студентов в профессиональный дискурс, но также формирует основы профессиональной идентичности, повышая у студентов мотивацию к обучению. Таким образом, очевидно, что одной из профессионально значимых компетенций любого специалиста, который по роду своей деятельности сталкивается с профессионально ориентированным иностранным языком, является дискурсивная компетенция. Для её формирования необходимо систематическое профессионально ориентированное обучение студентов, в ходе которого студенты учатся выполнять коммуникативные задачи, представленные в различной форме. 
К сожалению, учебный план составлен так, что бакалавры и магистры изучают иностранный язык только один раз в неделю. Учитывая рост потребности практического владения иностранным языком бакалавров и магистров в сфере экономики, такие условия можно с полной уверенностью назвать крайне неблагоприятными. При таком неоправданно ограниченном объёме учебных часов можно лишь констатировать, что курс обучения иностранному языку на неязыковых факультетах должен быть направлен на общеязыковую и профессиональную языковую подготовку одновременно, что в реальной жизни практически невозможно.

«Дискурсивность» научного текста реализуется на нескольких уровнях текстовой организации: типологическом - сохранение и реализация сложившихся жанровых форм; структурно-смысловом - включение процесса познания, отраженного в конкретном тексте, в общий процесс отражения научной картины мира; речевом - использование речевых вкраплений различного типа из других научных текстов.

В связи с тем, что широко практикуется в вузе написание студентами рефератов научного характера, которое направлено на формирование у них научного дискурса. Создание научного дискурса определяется характером деятельности исследователя и проходит ряд этапов:

1) выделение предмета исследования;

2) анализ истории вопроса;

3) формулировка гипотезы и цели исследования;

4) обоснование используемых методов и материалов;

5) построение теоретической модели;

6) изложение результатов наблюдений;

7) обсуждение результатов;

8) экспертная оценка исследования;

9) определение сферы практического применения полученных результатов.

Для обучения выпускников бакалавриата написанию научных текстов, например, резюме или обзорного реферата, требуется определенная система

анализа, которая показывала бы, как тексты разные по характеру могут быть едины в профессиональном дискурсе.

Таким образом, дискурсивная компетенция является одним из компонентов коммуникативной компетенции и поэтому тесно связана с остальными ее составляющими: лингвистической, социолингвистической, социокультурной и другими, которые формируются параллельно. Поскольку общеизвестно, что коммуникативная компетенция формируется в процессе овладения речевым общением и проявляется в нем, логично заключить, что равным образом формирование дискурсивной компетенции как ее компонента осуществляется в процессе обучения иноязычному общению. 
References:

[1] Willis D. Rules, Patterns and Words: Grammar and Lexis in English Language Teaching. Cambridge University Press, 2003. 238 p.

[2] Алещанова И.В., Фролова Н.А. Развитие дискурсивной компетенции на занятиях по иностранному языку в вузе // Успехи современного естествознания. 2014. № 11-1. C. 92-94.

[3] Кибрик А. А. Модус, жанры и другие параметры классификации дискурсов // Вопр. языкознания. 2009. № 2. С. 3-21. 


\title{
USE THE GRAMMAR RULES IN THE PRACTICAL LANGUAGE ACQUISITION
}

\author{
M. Nabiyeva ${ }^{1}$
}

\section{Abstract}

The article deals with the problems associated with the insufficiently effective use of methods for studying grammar in the foreign language. Analyzes the approaches and trends in the use of effective methods of studying grammar in the foreign language in schools, and recommendations on the choice of effective methods of learning a foreign language.

Keywords: grammar, analytical form, interlingua interference.

Мы знаем большое количество студентов, знающих правила употребления грамматики и даже их исключения, которые попадая заграницу, испытывают огромные трудности в повседневном общении. Многие люди, например, иммигранты, которые долгое время живут и работают в иноязычной среде, учат язык без грамматических пояснений, копируя то, что они слышат ежедневно. Они овладевают иностранным языком, не отдавая себе отчета в правилах, впитывая язык так, как это делают носители языка. "Неоспоримо то, что грамматика без коммуникации не представляет собой соразмерной учебной цели. Коммуникация же без грамматики делает занятие иностранными языками неэкономным и совершенно неэффективным". Бутцкамм называет это явление "чудом грамматики". Он считает, что "способность применять сложные грамматические конструкции в речи приходит тогда, когда мы забываем о правилах". Поэтому актуальной проблемой современной методики стала разработка грамматических упражнений коммуникативного характера.

Что такое грамматика? Выделившись из синтеза логико-философских вопросов, грамматика еще до нашей эры стала самостоятельной областью знаний. Понятие грамматика происходит от греческого grammatike и первоначально обозначало «искусство чтения и письма». В средние века «свободное искусство» grammatica считалось одним из компонентов всякого образования и ставило целью научить владению латинским языком (иногда и другими языками), сообщить сведения по филологии.

Грамматика как грамматический строй речи представляет собой особенности фактического словосочетания и соединения слов. Посредством грамматики формируются умения устного и письменного общения. Поэтому важно при обучении грамматике не только изучать теорию и добиваться ее усвоения, но и выдвигать в качестве первостепенной задачи практическое усвоение и закрепление особенностей иноязычной речи.

${ }^{1}$ Mahiba Nabiyeva, Associate Professor Department of Foreign Languages, Tashkent Financial Institute, Uzbekistan. 
Совершенно ясно, что полноценная коммуникация не может происходить вне или при отсутствии грамматики. Таким образом, попытка отказа от какой-либо грамматики с одной стороны, а с другой, преувеличение ее роли в учебном процессе отрицательно сказываются на результатах практического овладения языком. По мнению психолога Беляева Б.В., «надо не столько знать правила о том, как конструировать иноязычные предложения, сколько практически овладевать различными грамматическими конструкциями (моделями и структурами) в своей речи. Решающим фактором такого усвоения является иноязычно-речевая практика. Грамматические правила как теоретические знания сами по себе не обеспечивают образования соответствующих речевых навыков и умений.

Из истории немецкого и английского языков известно, что в них развились аналитические формы глагола, артикль. Ряд аналитических форм присущ и русскому языку. Как в немецком, так и в русском языке в наибольшей степени аналитизм при формообразовании проявляется в системе глагола.

Компоненты аналитической формы разделены и подвижны. Главная особенность аналитической формы состоит в том, что она выражает новое грамматическое значение, которое возникает только при сочетании определённых компонентов и выступает как значение неразложимого целого. Аналитические конструкции отличаются от аналитических форм тем, что они не являются специальным средством для выражения нового грамматического значения. Грамматические значения несёт в себе один из компонентов конструкции, но при этом лексически значимыми остаются все компоненты. Аналитическая конструкция также состоит, по меньшей мере, из двух компонентов, они разделены и подвижны. Выявляя аналитические тенденции в языке, необходимо принимать во внимание обе формы их проявления.

К аналитическим средствам современного немецкого языка относятся вспомогательные глаголы «haben», «sein», «werden» и артикли. Аналитические средства образуют в сочетании с полнозначными словами аналитические формы: перфект (ведущая разговорная форма прошедшего времени, результат действия непосредственно связан с действительностью: haben/ sein + Partizip II), плюсквамперфект (предпрошедшее, или давнопрошедшее время: haben/ sein (в претеритуме)+ Partizip II), будущее время (Futur I: werden + Infinitiv I; Futur II: werden + Infinitiv II) в изъявительном и сослагательном наклонениях, Konditionalis I и П, все формы страдательного залога (Passiv: werden + Partizip II; Stativ: sein + Partizip II), инфинитив пассив (Infinitiv + werden), инфинитив II страдательного и действительного залога, а также сочетания артикля и существительного.

Аналитические конструкции в значительной степени восполняют отсутствующую грамматическую категорию вида, выражая различные видовые значения начала, длительности, окончания, результата действия; они служат также выражению каузативности и пассивности. 
В последнее время в текстах научного, а также публицистического и официально-делового стиля получили широкое распространение глагольно-именные конструкции типа дать отчёт, обратить внимание, осуществить анализ, провести работу и т.п. они также являются аналитическими, так как неразрывно друг от друга выражают грамматические и лексические значения, обладают в некоторой степени идиоматичностью.

В немецком языке два основных способа словоизменения, имеющихся и в русском языке, а именно синтетический (аффиксация и внутренняя флексия) и аналитический (при помощи служебных слов), развиты приблизительно в равной степени, В русском языке явно преобладает синтетический способ (аффиксация).

Аналитические формы немецкого языка образуются при помощи флексии служебных слов, т.е. представляют собой флективно-аналитические формы. Артикль, при помощи которого образуются формы падежей, склоняется, причём именно его флексия выражает падеж (а также род и число), а вспомогательные глаголы (sein, haben, werden) спрягаются, выражая лицо и число знаменательного глагола при помощи личных окончаний. В русском языке флективно-аналитический характер имеет только одна форма -форма будущего сложного времени, образуемого со вспомогательным глаголом быть (например, буду читать). Для других аналитических форм характерна неизменяемость служебного слова. Так, неизменным остаётся более в сравнительной степени прилагательных, частица бы в сослагательном наклонении. Можно сделать вывод, что в немецком языке аналитические глагольные конструкции употребляются чаще, чем в русском языке (в немецких публицистических текстах аналитические глагольные конструкции составляют 7,7\% от общего объёма словоупотреблений, а в русских $-4,6 \%)$. При этом наиболее употребительными являются конструкции с модальными значениями (в немецких публицистических текстах - 66\% употреблённых аналитических конструкций, в русских текстах - 32\%). Следует отметить, что активно проникают в публицистический язык глагольно-именные конструкции с абстрактными существительными (в немецких публицистических текстах - 9\%, употреблённых аналитических конструкций, в русских текстах $-27 \%$ ).

Всё это можно считать проявлением аналитических тенденций в развитии русского и немецкого языков, а именно в сфере глагольной номинации. Это в свою очередь является отражением другой тенденции, воздействующей на немецкий и русский грамматический строй - росте номинализации и экономии языковых средств. Продуктивность моделей аналитических конструкций является предпосылкой создания новых лексем, в данном случае аналитических, при этом используются уже имеющиеся в языке лексические единицы.

Аналитические конструкции - это не инновация, это единицы центра грамматической системы, которые существуют в языке давно, но в процессе развития языка модифицируются. С точки зрения системы языка в целом аналитические формы являются зачастую более унифицированным 
способом выражения грамматических значений, а аналитические конструкции - средством модификации лексических значений.

References:

[1] Белогрудова В. П. Грамматика. Это интересно // Иностранные языки в школе. - 2004. - № 1. - С. 29.।

[2] Формирование грамматических навыков: учебное пособие/ Под. ред. Е. И. Пассова, Е. С. Кузнецовой.- Воронеж: НОУ «Интерлингва», 2002. - 40 с. 


\title{
MOTIVATIONAL MECHANISM REGULATORY STRATEGY AS LEARNING A FOREIGN LANGUAGE
}

\author{
N. Hashimov ${ }^{1}$
}

\section{Abstract}

The article considers the questions of the motivational strategies as a regulatory mechanism for learning a foreign language, the function of which is to create a common semantic space, about the problems of teaching a foreign language in not language high school; about the concept of "professional foreign language", the characteristic manifestations of internal, external and professional motivation activities.

Keywords: motivation, logical thinking, professionally-oriented competence.

Строить сегодняшнее и завтрашнее поведение на основе вчерашних знаний и вчерашнего опыта невозможно, что непосредственно отразилось на Государственном стандартном образовании.

Знание иностранного языка дает человеку такие практические возможности, как общение с представителями стран изучаемого языка, переписка с ними, чтение газет, журналов, книг по специальности художественной литературы в оригинале. Изучение иностранного языка воспитывает логическое мышление обучающихся: они учатся таким действиям, как умение сопоставлять и сравнивать, анализировать и синтезировать, делать выводы и умозаключения.

Теперь охарактеризуем те виды мотивации, которые имеют место при обучении, в частности, иностранному языку. Все вместе они составляют так называемую учебную мотивацию. Учебная мотивация определяется рядом специфических факторов:

- особенностями обучающегося (пол, самооценка, уровень интеллектуального развития)

- особенностями преподавателя и его отношения к педагогической деятельности

- организацией педагогического процесса

- спецификой учебного предмета (в данном случае иностранного языка)

C переходом на 4-х летнюю систему образования возникает критическая необходимость совмещать повторение базового уровня (а очень часто формировать этот уровень с нуля) с формированием прагматической межкультурной компетенции. Поэтому ключевой задачей преподавателя является выработка мотивационных стратегий поведения личности при изучении иностранного языка в неязыковом ВУЗе.

1Nargiza Hashimov, Senior Lecturer, Department of Foreign Languages, Tashkent Financial Institute, Uzbekistan. 
Мотивационные стратегии (результативно-целевая и процессуальная) являются регуляционными механизмами, которые позволяют корректировать силу мотивации обучаемых, которая прямо пропорциональна успеваемости. Оптимальное сочетание результативно-целевой и процессуальной мотиваций обеспечивает наибольшую успешность овладения студентами иностранным языком по показателям успеваемости и удовлетворённости. Функция мотивационных установок целевого типа состоит в создании единого смыслового пространства.

Итак, с самого начала занятия преподаватель обуславливает, каким будет контакт между ним и обучающимся. Если выступать за подлинное сотрудничество, то прежде всего цель урока ставится в терминах умений и навыков, а во-вторых, обучающемуся даётся возможность осознать их. Умение скорее рассматривается как условие совершенствования навыков, чем выступает в качестве цели. Комментарии по грамматическим правилам обычно воспринимаются только как сугубо языковые правила кодирования и декодирования, но не как правила создания нужного высказывания. Бытует мнение, что в формировании умений вообще нет необходимости, так как они уже сформированы в родном языке, и должны переносится на иностранный.

Преподавание ИЯ в неязыковом вузе сопряжено с особыми проблемами, связанными с деформацией гуманитарной, просветительской и учебно-воспитательной функций образования и нарушением соотношения подсистем методов обучения. Из этого следует необходимость сочетания методов, способов и приемов организации иноязычного общения в коммуникативном контексте профессиональной деятельности неязыкового вуза.

Учебное время, которое выделяется обучающимся для аудиторной и самостоятельной работы, зачастую сопрягается с отсутствием сформированных умений управлять самостоятельной деятельностью по системному овладению профессионально ориентированными компетенциями. Как следствие, возникает проблема разработки автономности обучения для обеспечения достаточного минимума знаний, сознательных умений и автоматизированных навыков.

В практике обучения в неязыковом вузе все более широкое применение находит понятие «профессиональный иностранный язык» (иностранный язык для специальных целей), разрабатываются новые подходы и технологии обучения. Однако, эффективность обучения в значительной степени определяется научным обоснованием инноваций. Значительная роль в научном обосновании принадлежит историко-логическому анализу, который позволяет оценить развитие методической мысли, учесть лучший зарубежный и отечественный опыт, понять современные тенденции и выявить перспективы развития.

Целью обучения специальному языку в наиболее широком смысле является подготовка к выполнению определенных обязанностей, требующих владения иностранным языком. Важной частью занятий является имитация профессиональной деятельности (доклад, участие в обсуждении 
и т.д.).

Таким образом, преподавание иностранного языка в неязыковом ВУЗе должно иметь свою специфику по сравнению с языковым ВУЗом, отражающую относительно низкую мотивацию и высокие трудности усвоения языка. Уровень мотивации тесно связан с уровнем успеваемости по предмету. Повышая мотивацию к изучению иностранного языка, мы повышаем и уровень его усвоения и как дополнительный положительный эффект получаем повышение успеваемости по этому предмету и субъективную удовлетворённость.

Выделяют некоторые характерные проявления внутренней мотивации деятельности:

- стремление к новизне. Для студентов неязыковых специальностей, изучающих иностранный язык, можно использовать их основную специализацию, в качестве преподавания уже знакомого им по профильным дисциплинам материала, возможны, незначительные добавления новой информации.;

- стремление к эффективному освоению мира. Чувство удовольствия от качественного выполнения какого-либо дела - сильнейший побудитель внутренне мотивированной активности.;

- самореализация, самоактуализация, самоосуществление, творческое и конструктивное человеческое «Я», которые начинают требовать своего проявления и реализации.

Основной разновидностью внутренней мотивации является коммуникативная мотивация, т.е. потребности формируются как чисто коммуникативные: говорить на иностранном языке с носителями языка, читать как художественную, так и специальную литературу, писать (например, письма). В атмосфере родного языка, иностранный предстает как искусственное средство общения, т.е. в основном, коммуникация носит условный характер, что сближает ее со сценической коммуникацией, отсюда обращение к воображению, фантазии.

Внешняя мотивация может быть дистантной, далёкой мотивацией, рассчитанной на достижение конечного результата учения. Внутренняя мотивация является близкой и актуальной, и весь учебный процесс должен быть построен таким образом, чтобы на каждом занятии учащиеся испытывали радость от удовлетворения потребностей, специфичных для изучаемого ими предмета, которым в нашем случае является иностранный язык.

Профессиональная мотивация и направленность сами становятся мотивом учебной деятельности, они стимулируют учебную активность студентов, их высокую академическую успеваемость, упорство в преодолении трудностей учения. Отношение студентов к различным учебным дисциплинам во многом зависит от оценки их важности в профессиональной подготовке по специальности.

На этапе вузовского обучения формирование профессиональной внутренней мотивации влияет на мотивацию изучения всех предметов и, следовательно, ей необходимо уделять особое внимание. 
Рассматривая феномен мотивации, необходимо уделить внимание и причинам понижения мотивации у студентов неязыковых специальностей при изучении иностранного языка, а также условиям и способам ее повышения. Существуют две группы причин снижения мотивации. Первая группа - причины, зависящие от преподавателя, вторая группа - причины, зависящие от студентов. Причинами, зависящими от преподавателя, являются неправильный отбор учебного материала, вызывающий перегрузку или недогрузку учащегося, низкий уровень владения преподавателем современными методами обучения, неумение строить отношения с учащимися и организовать их взаимоотношения друг с другом, особенности личности преподавателя.

Причины снижения мотивации, зависящие от студентов можно обобщить следующим образом: низкий уровень знаний, несформированность мотивов учебной деятельности и, прежде всего, приемов самостоятельного приобретения знаний; иногда не сложившиеся отношения с коллективом учащихся.

На уровень интереса влияет и положение науки в обществе, ее престижность. Очень большую роль играют методы преподавания учебного предмета и состояние учебников и учебных пособий.

Основываясь на вышесказанном, можно сделать вывод, что комплекс причин влияет на сформированность мотивов учебной деятельности в целом и иностранного языка в частности. Поэтому, можно говорить о том, что каждый студент находится на индивидуальном уровне сформированности мотивации изучения иностранного языка.

References:

[1] Готлиб Р.А. Социальная востребованность знания иностранного языка / Р.А.Готлиб / Социологические исследования, № 2, 2009. С. 122-127.

[2] Koshmanova I "90 Topics for Discussion in English" M.: 2002 


\section{FORMATION BILINGUAL COMPETENCE OF STUDENTS IN THE PROCESS OF STUDYING LANGUAGES}

\section{Aripova ${ }^{1}$}

\section{Abstract}

The article deals with the "foreign language" of the subject, its specificity, given the concept of what is meant by bilingual competence of the difference between the level of ownership of a foreign language, about the influence of analogies in their native language, that when you try to use foreign words distort its meaning about bilingual / bicultural communication skills.

Keywords: bilingualism, language transfer, competence, interference.

При обучении речевой деятельности на иностранном языке учебный предмет «иностранный язык» является предметом сравнения, сопоставления с родным. Именно на формирование у студентов правильного употребления основных моделей иностранного языка должна быть направлена деятельность преподавателя.

Предметом специального осознания должны быть не элементы системы изучаемого языка, которые исполняют важную роль в реализации коммуникативного намерения.

Под билингвальной компетенцией понимается «способность обучаемого осуществлять общение на двух языках, в контексте двух культур, переключаясь с одного языкового кода на другой, проявляя сензитивность к различиям в двух культурах». Билингвизм - особо актуальное в наше время явление, когда количество людей, свободно владеющих более чем одним языком, возрастает.

Чтобы добиться высокой степени аутентичности иноязычной речи билингвов, создать платформу для развития двуязычной языковой компетенции, преподавателю следует учитывать особенности национальной стилистики, коммуникативных стратегий и речевых тактик как родного, так и приобретаемого языка. Показателем успешной иноязычной подготовки будущего специалиста неязыкового профиля является успешная аккультурация как способность к оптимальной жизнедеятельности в иноязычной и инокультурной среде. Необходимым условием аккультурации выступает билингвальная ЛР (лингвориторическая)-компетенция языковой личности, обеспечивающая формирование на базе усвоения иностранного языка подструктуры «вторичной языковой личности».

Языковой перенос правомерен и возможен, если языковые подсистемы сопоставимы. Например, в русском и английском есть категория числа (единственное и множественное), есть части речи, общие для двух языков,

${ }^{1}$ Mashkur Aripova, Senior Lecturer, Department of Foreign Languages, Tashkent Financial Institute, Tashkent, Uzbekistan. 
категории настоящего, прошедшего и будущего времени и т.д. Однако те или иные лингвистические явления и категории могут быть в одном языке и отсутствовать - в другом. Например, в английском имеются герундиальные и инфинитивные комплексы, перфектные формы, артикли, продолженное время, но их нет в русском; в русском же, в отличие от английского, развиты морфология и согласование форм слов в предложении, есть склонение существительных и т.д.

Различают три уровня владения чужим языком: начальный (второй язык выполняет только информативно-коммуникативную функцию), переходный (среди прочего проявляется экспрессивная функция) и адекватный (возникает мыслительный процесс на втором языке). Так, например, существует системная организация практики речемыслительной деятельности обучающихся на интегративной ЛР-основе в разных режимах коммуникации (монологический, диалогический), регистрах речемыслительной деятельности (рецептивный, репродуктивный, продуктивный), ее формах (устная, письменная), стилях (официально-деловой, публицистический, научный, художественный, разговорный), типах (описание, повествование, рассуждение, оценочное суждение), жанрах профессиональной речи (специфика речи бизнесмена; деловой переписки, оформления документов и др.);

Билингвальная компетентность рассматривается в основном, как развитие речи обучающихся, развитие интеллектуальных и личностных свойств, формирование мышления, ускоренное развитие речевого интеллекта и речемыслительной деятельности, развитие любознательности и широкого кругозора и т. д.

Под влиянием аналогий в родном языке нередко при попытке употребления иностранного слова происходит искажение его значения.

Так, английское science подразумевает только естественные науки, humanities - гуманитарные; русские же, говоря по-английски, как правило, не разграничивают этих значений и используют science и для естественных, и для гуманитарных наук, так как в русском языке понятие наука объединяет все отрасли знания. То же происходит с такими словами, как barracks (казармы, а не бараки), salute (приветствие, а не салют), minister (священник в первом значении лексемы) и т.д.

Особенности стилистики английской и русской речи проявляются прежде всего в диалоге, который содержит набор предложений различных коммуникативных типов: вопросов, ответов, императивов. Наибольшее разнообразие вариантов среди вопросов-запросов информации и квазивопросов (вопрос-совет, вопрос-побуждение, вопрос-подтверждение и т.п.). В большинстве случаев вопрос, запрашивающий информацию, в русском более прямолинеен и менее вариативен, чем в английском. Ср.: Не скажете (не знаете), который час? и Could you tell me the time, please? Would you know the time? Do you happen to know what time it is (what's the time)? Для подобных вопросов в английской речи характерна, пользуясь понятием В.Г Гака, разговорная проксемика -соблюдение психологического расстояния между говорящими. 
Известно, что мы воспринимаем звуки языка, образуемые речевым аппаратом человека и являющиеся в системе данного языка сигналом предметов и явлений реальной действительности. Благодаря отражению звуков в сознании человека, мы способны через воспринимаемые звуки различать значения слов.

Восприятие речи на слух опирается главным образом на слуховые ощущения. Восприятие речи собеседника облегчается, когда мы видим его лицо, следим за положением органов речи, за мимикой. Зрительные ощущения, хотя и не являются непременным условием восприятия речи на слух, играют в нем положительную роль. В русском языке интонация является единственным средством выражения вопроса и поэтому несет большую грамматическую нагрузку. В английском языке интонация меняется только в общем вопросе, но и здесь она является второстепенным средством, так как решающее значение для выражения вопроса имеет порядок слов.

Студент, говоря на родном языке, не задает вопроса: почему - так надо сказать, но ищет объяснение всем почему, когда надо говорить и писать на изучаемом чужом иностранном языке. Родной язык в процессе понимания нового языкового выражения мыслей и чувств присутствует как своеобразное мерило этих языковых способов выражения, новых языковых явлений и фактов.

На основе билингвальных/бикультурных коммуникативных умений формируется способность обучаемых к сознательному общению с представителями других культур.

Значительные трудности может вызвать смешение частей речи как результат ложной интерференции. Например, студенты довольно часто совершают ошибки типа *he afraided (вместо he was afraid) под влиянием русского «он боялся». Подобную ошибку можно отметить при построении предложения *I wasn't agree with him (I didn't agree with him) по образцу с русским «Я не был согласен с ним». В данных случаях необходимо обратить внимание студентов, что слово afraid не является глаголом, поэтому не может принимать суффикс -ed, в то время как agree - английский глагол, который образует отрицательную форму прошедшего времени при помощи вспомогательного глагола did. Или, не зная фразы "as dead as a dodo", которая означает потерю популярности, ученик не сможет перевести предложение: The president's plans to animate the nation's economy are as dead as a dodo. - Планы президента оживить национальную экономику абсолютно бесперспективны. "Dodo" это дронт. Птица, которая была истреблена в 15 веке. Потому выражение «as dead as a dodo» имеет вышеупомянутое значение.

Таким образом, билингвальное обучение в системе экономических дисциплин это формирование у студентов билингвальной профессиональной компетенции, которая выражается в овладении знаниями, умениями и навыками в сфере экономики и способности применять их в ситуациях делового общения на иностранном языке. 
References:

[1] Брыксина, И.Е. Технология профессионально ориентированного обучения иностранному языку бакалавров психолого-педагогического образования (билингвальный / бикультурный аспект) [Текст] / И.Е. Брыксина // Социальноэкономические явления и процессы. 2012. № 3(037). С. 151-156.

[2] Гак В. Г. Язык и культура: язык или культура? // Язык и культура: материалы II Междунар. науч. конф. М., 2001.

[3] Щепилова, А.В. Теория и методика обучения французскому языку как второму иностранному / А.В. Щепилова // Учеб. пособие для студентов вузов. М.: Гуманитар. изд. центр ВЛАДОС, 2005. 245 с. 


\section{USING VARIOUS FORMS OF VISUALIZATION OF GRAMMATIC CONSTRUCTIONS OF FOREIGN LANGUAGE}

\section{Zakirova ${ }^{1}$}

\section{Abstract}

The article discusses the use of various forms of visualization of grammatical constructions, analyzes syntactic constructions of foreign languages, grammatical skills that are divided into two groups, the advantages of an inductive method of presentation of material, the basics of communicative grammar, and the problems that exist in the teaching of grammar.

Keywords: visualization, grammatical constructions, inductive method, communicative grammar.

Но ведь для того, чтобы общаться на языке, совсем не обязательно знать досконально все тонкости грамматики. Думаю, что немногие из носителей русского языка станут утверждать, что знают все правила грамматики и правописания русского языка. Обычно всех, кто что-то слышал о немецком языке, приводит в ужас пресловутая рамочная конструкция, при которой глагол, отрицание или вторая часть составного сказуемого ставится в самом конце предложения и могут изменить смысл всей фразы (дополнительная сложность при синхронном переводе с немецкого!). Но в действительности рамочная конструкция применяется не так уж редко и в русском языке: просто мы об этом не задумываемся. Попробуйте проанализировать на досуге синтаксические построения русского языка, и Вы найдете немало сходства с немецким. В немецком и русском языках вообще много схожего: и в лексике, и в самой логике построения фраз. Существует великое множество фразеологических выражений, пословиц и просто реалий, существующих практически в одинаковом виде в русском и в немецком языках. Поэтому многие вещи с русского на немецкий и с немецкого на русский можно переводить практически буквально, не опасаясь быть непонятым.

Превозносимый всеми за мнимую легкость английский язык отстоит от русского в десятки раз дальше. Перевод с английского языка, даже если речь идет о техническом переводе, это сплошные муки творчества, словно речь идет о переводе романа. Синтаксическое строение фраз в русском и английском совершенно не совпадает.

В содержание обучения грамматике входят правила и грамматические явления, а также грамматические навыки употребления явлений, конструкций и грамматических структур.

1Dilorom Zakirova, Senior Lecturer, Department of Foreign Languages, Tashkent Financial Institute, Uzbekistan. 
Грамматические навыки делятся на две группы: рецептивные и продуктивные. К рецептивным грамматическим навыкам относятся аудирование и чтение, а к продуктивным - говорение и письмо. При обучении грамматике используется два подхода: имплицитный (без объяснения правил) и эксплицитный (с объяснением правил).

Для того чтобы воспринять ту или иную грамматическую структуру

вовсе недостаточно ее анализа на уровне слова или предложения. Для этого необходимо рассматривать их в определенном контексте, позволяющем понять коммуникативную нагрузку, которую несет данная грамматическая структура. Говорение и все речевые действия студентов осуществляются в определенном контексте, а не выступают просто в качестве персонажей учебного пособия, поэтому задача преподавателя - научить их реализации

своих языковых намерений в соответствующей грамматической форме, концентрируясь при этом не только на грамматической форме, но и на содержательной стороне высказывания.

Доказано, что грамматические структуры гораздо лучше усваиваются при использовании различных форм их визуализации. При этом можно использовать как индуктивный, так и дедуктивный метод презентации материала. Современная методика отдает преимущество индуктивному методу, при котором студенты самостоятельно постигают коммуникативную функцию определенных грамматических структур, в отличие от дедуктивной методики, когда преподаватель заранее предлагает те или иные правила, иллюстрируя их множеством примеров.

Современная концепция преподавания грамматики основана на том очевидном факте, что человеческое общение представляет собой не простой обмен информации. Каждый из собеседников стремится не только донести либо узнать необходимую информацию, но и привносит в процесс общения свое эмоционально-оценочное отношение. Поэтому студентам необходимо научиться анализировать предлагаемые структуры с формально-языковой точки зрения.

Если рассматривать с точки зрения лингвистики, прагматико-лингвистический подход к преподаванию грамматики - это основа коммуникативной грамматики, но в тоже время не теряет своей актуальности при этом и так называемый «системный» подход. При этом преподаватель не просто передает свои знания студенту, а выполняет скорее функцию помощника в учебном процессе.

Коммуникативный подход в преподавании иностранного языка сместил акценты с грамматики как набора структурных элементов языка на грамматику как на систему вспомогательных средств, необходимых обучающемуся для правильной организации чтения, письма, понимания услышанного и говорения. Иными словами, сама грамматика не является целью обучения. В отличие от лингвистической грамматики, коммуникативная грамматика не стремится к полному описанию и объяснению языковой системы, а подает избирательно лишь те части, правила языковой системы, 
которые могут использоваться для достижения определенной коммуникативной цели.

Существуют три насущные проблемы в преподавании грамматики

иностранного языка: сосуществование и одновременное функционирование грамматических понятий в различных лингвистических моделях (Subjekt/Nominativergänzung/Subjektergänzung); негативный эффект грамматико-переводческого метода преподавания иностранного языка на мотивацию изучения грамматики обучающимися; вопрос избирательности грамматических структур в обучении говорению на иностранном языке.

В связи с этим целесообразно подчеркнуть следующие аспекты изучения грамматики, которым необходимо отводить место на занятии по иностранному языку:

а) содержательное и визуальное отображение грамматических правил, стимулирующее их запоминание с последующим правильным употреблением;

б) ситуативная привязка грамматических конструкций на стадии их введения и семантизации;

в) разнообразие видов упражнений, направленное на тренировку грамматических аспектов в различных коммуникативных ситуациях;

г) унификация грамматических понятий в рамках изучения иностранного языка в одной группе;

д) индуктивная подача грамматики, при которой возможно выведение самими учащимися грамматических правил из набора представленных частных случаев.

Ситуативная привязка грамматических конструкций на стадии введения и семантизации способствует локализации данных конструкций в определенную коммуникативную сферу их употребления. На данной стадии так же целесообразна визуализация. Так, например, введение конструкций, используемых в официальном стиле коммуникации, может сопровождаться фотографиями, картинками, карикатурами, изображающими деловые переговоры и т. п.

Остановимся подробно на возможности визуализации грамматики. Визуализация грамматических конструкций в учебниках возможна при помощи целого ряда средств, как например, графические средства (величина и цвет шрифта), абстрактных символов, передающих содержание определенной грамматической категории (субъект, предикат, объект); визуальной метафоры (передача содержания грамматической конструкции при помощи визуального образа). Так, например, принцип формального отсоединения в немецких глаголах с отделяемой приставкой может быть визуально отображен при помощи образа ножниц, перерезающих глагол как целостную единицу на две части.

Визуальная поддержка в процессе изучения грамматики возможна также и на стадии тренировки и систематизации. Так, разнообразие грамматических упражнения с использованием образного визуального материала (картинки, карты, карикатуры) не только способствует наилучшему 
его усвоению, но и выполняет мотивационную функцию в процессе обучения грамматике.

References:

[1] Москальская О.И. Теоретическая грамматика современного немецкого языка GrammatikderdeutschenGegenwartssprache: Учеб. для студентов вузов, обучающихся по спец.: 022600 Теория и методика преподавания иностр. яз. и культур, 022900 Пер. и переводоведение, 023000 Теория и практика межкультур. коммуникации, направления 620100 Лингвистика и межкультур. Коммуникация / Ольга Ивановна Москальская. М.: Academia, 2004. 348 с.

[2] Формирование грамматических навыков: учебное пособие/ Под. ред. Е. И. Пассова, Е.С. Кузнецовой. Воронеж: НОУ «Интерлингва», 2002. 40 с. 


\section{USE OF MODERN EQUIPMENT FOR TRAINING CHINESE LANGUAGE TO HIEROGLIFIC LETTERS}

\section{Z. Abdurakhmanova ${ }^{1}$}

\section{Abstract}

The article deals with the means of teaching the Chinese language as a foreign language, about the peculiarities and originality of the hieroglyphic writing, about the difficulties of the Chinese language, in which it is necessary to master an entirely different way of expressing one's thoughts, as well as taking into account and applying a wide range of didactic, And the private-methodological principles that underlie modern approaches to the methodology of teaching foreign languages.

Keywords: hieroglyphic writing, Chinese script, principle of visualization.

Изучение иностранного языка - эффективное средство социализации личности, интеллектуального развития студента, выработки новых стандартов разных форм деятельности, ориентированных на мировую практику. Знание иностранных языков необходимо для продолжения обучения и осуществления профессиональной деятельности в иноязычной среде.

В последние годы особенно большой интерес вызывает изучение китайского языка, в том числе и у студенческой молодёжи. Немаловажную роль играет активное использование китайского языка в научно-исследовательской работе студентов, аспирантов и соискателей. Знание китайского языка значительно расширяет источниковую базу исследований, так как появляется возможность знакомства со многими материалами и документами на языке оригинала.

Китайская иероглифическая письменность является неотделимой частью китайской цивилизации в целом. За 4 тысячелетия своего существования она стала отражением китайских традиционных особенностей, и до сих пор является единственным общепринятым способом записи китайского языка. Знак китайского письма представляет собой сложную графическую фигуру. Его китайское название 字 [zм] - иероглиф. В отличие от русских букв, которые обозначают определенные звуки, китайский иероглиф означает какое - либо понятие.

Каждый иероглиф имеет большое количество значений, объединяющее в одно целое зрительные, слуховые, обонятельные, осязательные и ментальные признаки, явления реальной жизни и восприятие человека.

Своеобразие системы китайского письма, трудности усвоения и использования, существенные отличия от алфавитных систем, а также отно-

1Zubaido Abdurakhmanova, senior lecturer of the Department of "Topless Languages", Uzbek State University of World Languages, Tashkent, Uzbekistan. 
сительная автономность от устной коммуникации - все это требует пристального внимания к проблемам методики обучения иероглифики. Запоминание иероглифического знака предполагает гораздо больше мыслительных операций, чем запоминание букв алфавита.

Восприятие китайского языка в иноязычной аудитории наталкивается на целый ряд трудностей. Говорить на китайском сравнительно легко, после овладения тонами. Грамматика тоже проста. Но вот иероглифическое письмо - это испытание, прохождение которого сулит определенные бонусы. Иероглифика, которая в настоящее время насчитывает порядка 50 тысяч иероглифов, а если иметь в виду наличие простых и сложных иероглифов, которые появились в ходе реформирования китайской письменности, то эта цифра значительно станет больше.

Кроме указанных трудностей, необходимо овладеть совершенно другим способом выражения своих мыслей. Грамматический строй китайского языка существенно отличается от привычного для европейских языков. Если переводчик с европейского языка может синхронно переводить речь говорящего по частям, то переводчик с китайского обязательно должен выслушать мысль до конца, так как все определения предшествуют определяемому слову.

Для построения эффективной системы обучения иероглифическому письму необходим учет и применение в практике преподавания широкого диапазона дидактических, обще- и частно-методических принципов, лежащих в основе современных подходов методики обучения иностранным языкам.

Важное значение в организации процесса обучения иероглифическому письму имеет принцип наглядности. Его необходимость обосновывается «диалектикой перехода от чувственного восприятия к абстрактному мышлению в процессе познания». В соответствии с принципом наглядности обучение строится на конкретных образах, непосредственно воспринимаемых обучающимися, целью применения изобразительных смысловых опор является активизация необходимых ассоциаций между изображением (идеей, смыслом) и тем, что станет содержательным материалом высказывания.

В методике обучения китайскому иероглифическому письму языковая наглядность может быть представлена в виде особой, концентрической организации иероглифического материала в иероглифические «кластеры». Кластер (от англ. cluster - пучок, гроздь) - это совокупность однородных элементов, идентичных объектов, образующих группу. Основным условием объединения определенных иероглифических знаков в кластеры является наличие у них некоторого признака, который позволяет проследить взаимосвязь между ними. Иероглифический кластер может быть построен на основе графической формы, звукобуквенного стандарта или семантического значения. В качестве иллюстрации приводится иероглифический кластер «Человек», построенный на графическом компоненте 人 «человек». 
Например, весьма эффективной является методика обучения иероглифическому письму на основе графических признаков иероглифических знаков

Основное внимание авторы методики уделяют объяснению базовых графических элементов (ключей-детерминативов), объединенных по тематическому принципу, например, тема «природа» представлена ключами 日 rì «солнце», 月 уuѐ «месяц», 气 qì «воздух», 风 fēng «ветер», 火 huǒ «огонь», 水 shuǐ «вода» и т.д.

Применение игр на занятиях иностранного языка положительно влияет на обучающихся. Большой плюс игры в том, что она держит внимание всех участников, так как их ответ зависит от ответа других.

Иероглифическое лото: игра на изучение, запоминание и повторение основных графем. Мы используем японский вариант игры.

Игра может быть, как командной, так и индивидуальной. Перед началом просматриваем все графемы, называем их чтение и значение. Для самого первого раунда достаточно 20 наиболее употребительных графем: 口 日田人大火月力刀女子手木目水山川白土. Далее количество увеличивается и постепенно доводится до 100. Участникам раздаются карточки с графемами и дается время на раскладку и ознакомление с ними. У учителя в руках картинки соответствующих предметов или понятий. Учитель вытягивает картинку и показывает ее всем. Команда или игрок, у которого обнаруживается карточка с соответствующей графемой, откладывает ее в сторону. Выигрывает тот, у кого больше не остается карточек. Играем в конце урока.

Иероглифические пазлы: игра на запоминание иероглифов. Игрокам раздается по три иероглифа, разрезанных на 9 частей. Побеждает тот, кто первым правильно соберет все иероглифы. Тренировка зрительной памяти.

Иероглифические загадки: способствуют развитию логики, пониманию структуры иероглифа, повторению графем.

1. 田中有 :

2. 夫没有人 :

3. 我没有，他有，天没有，地有：

4. 坐没有人 :

5. 人有他大, 天没有他大, 你也认识他, 他是谁?

Многие упражнения по китайскому языку должны быть связаны с коммуникативными потребностями студентов, направлены на пробуждение интереса к познавательной деятельности.

В этих целях необходимо широко использовать следующие задания:

Пересказать или записать иероглифами текст (ответить на вопросы, составить тезисы, аннотацию, реферат).

Проанализировать текст (его идею, вид текста, его композицию, грамматические конструкции, лексические особенности). 
Прочитать или пересказать текст с выражением, с учётом интонации каждого предложения, тонов в каждом слове.

Трансформировать предложенный текст (высказать своё мнение, расширить, дополнить по своему усмотрению, продолжить его).

Такие формы заданий вызывают интерес у студентов и улучшают результат.

References:

[1] Гальскова Н.Д., Гез Н.И. Теория обучения иностранным языкам: Лингводидактика и методика. М.: Издательский центр «Академия», 2013. 336с.

[2] Задоенко Т.П., Хуан Шуин. Основы китайского языка. Основной курс. М.1993., с.5

[3] Масловец О.А. Методика обучения китайскому языку в средней школе. М.: Восточная книга, 2012. 184c. 


\title{
APPLICATION OF WEB QUEST TECHNOLOGIES IN TRAINING FOREIGN LANGUAGE
}

\author{
N. Abdurakhimova ${ }^{1}$
}

\section{Abstract}

The article deals with the application of the Web-based technology quest in the lessons of a foreign language. This technology provides three main components of productive language learning: problem, authenticity and interactivity, which is a leading factor in learning a foreign language. Web-Quest technology includes not only the original form of training, but also the content, methods of teaching and control, but also enables you to remotely control the independent educational activity of students in a prepared and didactically structured Internet environment.

Keywords: web-quest technology, innovative method, foreign language environment.

Преподавание любой дисциплины обязано учитывать существующие тенденции развития общества, а также запросы общества относительно предъявляемого образовательного продукта, поскольку именно они являются критерием востребованности выпускников системы образования и, значит, основой для применения тех или иных методик и технологий, направленных на достижение требуемого результата. Сегодня мы наблюдаем глобальный социальный процесс, связанный с переходом к информационному обществу, когда центр тяжести смещается из области материального производства в область создания информационных продуктов и осуществления информационной деятельности, а именно, сбора, накопления, обработки, хранения, передачи, использования, продуцирования информации.

К сожалению, чаще всего можно наблюдать пассивное восприятие информации, полученной в Интернете, что приводит молодых людей к стереотипности мышления, искаженному мировоззрению, снижению учебной мотивации. С таким отношением Интернет-ресурсы становятся не базой для развития компетентности личности, а универсальной шпаргалкой на все случаи жизни. Между тем развивающиеся информационные технологии предлагают массу возможностей для совместной работы студентов и преподавателя. По мнению многих учителей, успешно внедряющих вебквесты в учебный процесс, данная технология предоставляет три основных составляющих продуктивного языкового обучения: проблемность, аутентичность и интерактивность, которая является ведущим фактором в

${ }^{1}$ Nigora Abdurakhimova, Senior Lecturer, Department of Oriental Languages, Uzbek State University of World Languages, Tashkent, Uzbekistan. 
обучении иностранному языку. Веб-квесты позволяют обучающимся получать информацию в устной и письменной форме (чтение веб-страниц или участие в дискуссии на изучаемом языке).

Веб-квест (webquest) - это один из сложных учебных Интернет-ресурсов, который представляет собой сценарий проектной деятельности по какой-нибудь теме с использованием ресурсов глобальной сети Интернет. «Веб-квест имеет четко обозначенную структуру и направлен на исследование и всестороннее изучение отдельно взятого проблемного вопроса, часто связанного с будущей профессиональной деятельностью иностранных студентов».

Веб-квест включает в себя в качестве обязательных следующие части:

- введение (тема и обоснование ценности проекта). Этот этап предоставляет основную информацию, вводит ключевые понятия, а также содержит вопрос, над которыми будут размышлять студенты;

- задание (цель, условия, проблема и пути ее решения). Это наиболее важная часть Веб-квеста. Задание направляет студентов на ряд конкретных действий на пути решения проблемы;

- процесс (поэтапное описание хода работы, распределение ролей, обязанностей каждого участника, ссылки на интернет-ресурсы, конечный продукт). В этом разделе содержатся указания, как именно студенты будут выполнять задание (порядок выполнения и сортировки информации);

- оценка (шкала для самооценки и критерии оценки преподавателя). Раздел содержит критерии оценки выполненного задания в соответствии с определенными стандартами;

- заключение (обобщение результатов, подведение итогов (чему научились, какие навыки приобрели; возможны риторические вопросы или вопросы, мотивирующие дальнейшее исследование темы). Здесь подводится итог и поощряется рефлексия и дальнейшие исследования по проблеме;

- страницы для преподавателя (дополнительно): в них содержится информация для помощи другим преподавателям, которые будут использовать веб-квест.

Предварительный отбор преподавателем сайтов позволяет исключить вероятность использования студентами сайтов с неподтвержденной, ложной или необъективной информацией. Представленная в мультимедийном виде информация имеет иные свойства, чем информация, данная в учебниках. Она не ориентирована на усвоение знаний и понимание, а направлена лишь на формирование образа, не имеющего структуры. Кроме того, в Интернете различные формы информации переплетены между собой и воздействуют на психику человека с помощью эффектов: сочетания цвета, звуков и символов. Еще одна проблема заключается в том, что находящаяся в Интернете информация представлена в различных жанрах, стилях, имеет различную адресную направленность, по-разному интерпретируются одни и те же факты.

Веб-квесты - это не только инновационный метод обучения и контроля полученных знаний преподавателем, но и новый метод получения 
(или, точнее сказать, «добывания») знаний студентами, т. е. отказ от насильственного навязывания готовых ответов. Здесь преподаватель выступает в роли помощника, который скорее направляет самостоятельный творческий процесс поиска ответов на поставленные вопросы в веб-квесте. Вопросы веб-квеста являются своеобразным «скелетом» его выполнения. Безусловно, составление хорошего веб-квеста требует времени и высокого профессионализма. Веб-квесты способствуют также развитию у студентов навыков, необходимых для человека XXI в.: умение ориентироваться в огромном потоке информации, умение анализировать, самостоятельно и творчески мыслить, объективно оценивать свои достижения, умение работать в команде, идти в ногу со временем и т. д.

Разработчиками веб-квеста как учебного задания является Берни Додж, профессор образовательных технологий Университета Сан-Диего (США).

Им определены следующие виды заданий для веб-квестов, перечислим некоторые из них:

- Пересказ - демонстрация понимания темы на основе представления материалов из разных источников в новом формате: создание презентации, плаката, рассказа.

- Самопознание - любые аспекты исследования личности.

- Творческое задание - творческая работа в определенном жанре - создание пьесы, стихотворения, песни, видеоролика.

- Аналитическая задача - поиск и систематизация информации.

- Оценка - обоснование определенной точки зрения.

- Научные исследования - изучение различных явлений, открытий, фактов на основе уникальных онлайн источников.

Результаты выполнения веб-квеста, в зависимости от изучаемого материала, могут быть представлены в виде устного выступления, компьютерной презентации, эссе, веб-страницы и т.п. Пересказ в него входит: демонстрация понимания темы на основе представления материалов из разных источников в новом формате: создание презентации, плаката, рассказа. Планирование и проектирование - это разработка плана или проекта на основе заданных условий. И результат самопознание, которое представляет собой любые аспекты исследования личности. Среди образовательных веб-квестов популярен QuestGarden, который предлагает реализовать большое количество проектов или создать свой собственный веб-квест.

Применение этой методики в работе со студентами, изучающими иностранные языки, способствует созданию у студентов устойчивого интереса к изучению иностранного языка и совершенствованию речевых умений и навыков, приобщению к чтению художественной, публицистической и специальной литературы на иностранном языке, совершенствованию интеллектуальных способностей личности, получению эстетического и познавательного интереса, реализации креативного потенциала.

Полезные ссылки:

http://www.webquest.org/

http://k6educators.about.com/ 
http://www.teach-nology.com/web_tools/rubrics/webquest/ http://edweb.sdsu.edu/webquest/serching/sevensteps.html

References:

[1] Полат, Е.С. (2000) Метод проектов на уроке иностранного языка // Иностранные языки в школе. № 3. С. 3-9.

[2] Сысоев, П.В., Евстигнеев, М. Н. (2009) Разработка авторских учебных Интернетресурсов по иностранному языку // Иностранные языки в школе. № 2. С. 8-16.

[3] Fried-Booth, D. L. (1988) Project Work: Resource Books for Teachers. Ed. by Alan Maley. Oxford: Oxford University Press. 


\title{
USE OF AUDIOVISUAL FUNDS \\ IN THE LEARNING OF CHINESE LANGUAGE
}

\author{
N. Abdullaeva ${ }^{1}$
}

\section{Abstract}

The article examines the changes occurring in the learning process associated with the so-called "visual turn" and, as a consequence, the emergence of a new type of trainees inclined to perceive new information visually. Modern software products help the teacher of the Chinese language to use new means of visualization. Examples are given of the use of modern visual aids in the educational process and the tools of its creation.

Keywords: visualization; Visual learning tools; Information and communication technologies.

В настоящее время в условиях непрерывного развития отношений Узбекистана с Китаем в нашей стране весьма актуальной является задача подготовки специалистов, владеющих китайским языком как средством общения с носителями языка для выполнения различных видов деятельности.

Все разнообразие вспомогательных средств, используемых в обучении иностранным языкам, целесообразно разделить на две большие и далеко не равные по значению группы. К первой группе следует отнести так называемые традиционные (нетехнические средства), ко второй - современные технические средства обучения. С внедрением в учебный процесс аудиовизуальных средств и компьютеров, появляются другие способы кодирования: звучащее слово и стереоизображение. Тем не менее в подавляющем большинстве учебных ситуаций использованию визуальных учебных средств следует отводить более скромную роль по сравнению с применением аудитивных или визуально-аудитивных средств. Все это подводит нас к заключению о том, что среди традиционных средств обучения иностранным языкам речь учителя, в каком бы «ключе» она ни преподносилась (повествование, инструкция, разъяснение, участие в диалоге и т. д.), имеет решающее значение, потому что в этом случае обучающиеся воспринимают поток звучащей иноязычной речи.

Поколение визуалов и кинестетиков естественно воспринимает подачу материала в виде презентации. Помимо известных достоинств (иллюстративность, включение нескольких органов чувств, прозрачная организация занятия) включение презентации в структуру урока имеет дополнительный эффект иллюзии - в презентации всё легче, чем в скучном бумажном

${ }^{1}$ Nazokat Abdullaeva, senior teacher, Department of Oriental Languages, Uzbek State University of World Languages, Tashkent, Uzbekistan. 
«кирпиче». Однако использование презентаций сталкивается с проблемой слабой подготовленности преподавателя. Вспомогательные материалы, демонстрируемые с помощью технических средств, можно разделить на три группы: фонограммы, фотограммы и видеофонограммы.

Аудиовизуальные средства обучения способны достаточно эффективно через систему зрительных и слуховых образов знакомить студентов не только с единицами языка, но и через их посредство с историей и культурой Китая, обеспечивая таким образом страноведческую направленность процесса обучения. Важную роль при комплексном обучении всем аспектам китайского языка таких как фонетика, грамматика, лексика и иероглифика играет использование новейших информационных технологий при конструировании современной образовательной среды для изучения китайского языка, а потому представляется одним из важнейших средств для практического овладения китайским языком. В то же время применение подобных новых методов и принципов преподавания при проектировании научно-методической работы в системе обучения ведет к повышению качества управления образовательной средой, обеспечивает гибкость образовательного процесса, совершенствует способности к саморазвитию личности и способствует развитию индивидуализации в организации учебной деятельности студента в зависимости от личных возможностей и потребностей. Применение аудиовизуальных материалов при обучении иностранным языкам в современный период приобретает все больший размах благодаря быстрому развитию информационно-технических средств и глобализации образовательного пространства, а также расширению возможностей обмена методическим опытом между образовательными учреждениями разных стран.

Речь идет о том, что абсолютное большинство так называемых «слов» ( 词 современного китайского языка можно представлять, как некий продукт семантической комбинаторики, семантической «игры в кубики» с весьма ограниченным списком правил сочетаний и фактически бесконечной семантической палитрой идиоматики.

Уникальность китайского письменного текста, как некоего семантического «игрового поля» с использованием 字, очевидна для исследователей древних текстов, указывающих на китайский текст, как на «метаязык символов, осмыслить значение которых мы можем через описание системы их взаимоотношений друг с другом». Между тем, современный китайский язык, в разной степени сочетая правила организации вэньяневских текстов с нормами разговорной речи и балансируя на грани между 字 -словами и 词-словами, также становится площадкой для семантической игры. Для большинства изучающих китайский язык уже на довольно раннем этапе его освоения указанная выше игра становится очевидной, у обучаемого включается языковая догадка, а порой - собственное языкотворчество.

Задания, представленные в курсе, призваны тренировать такие ас- 
пекты речевой деятельности для обучения иностранному языку, как чтение, письмо и аудирование.

Наибольшее отличие китайского от остальных языков заключается в символьной, а не звуковой азбуке. Когда английский ребенок учится читать, он ассоциирует написанную букву со звуком, а звук слов автоматически расшифровывается мозгом и дает его значение. Когда читать учится китайский ребенок, он должен отдельно ассоциировать иероглиф с его смыслом и отдельно - со звучанием. Это удваивает усилия, прилагаемые мозгом в процессе чтения, и, соответственно, тренирует способности человека.

В процессе преподавания китайского языка в высших учебных заведениях необходимо учитывать возрастные и психологические особенности учащихся. У взрослых людей преобладает логическая память над механической, зрительная над слуховой. Они легче запоминают грамматику, чем слова, так как для запоминания грамматических норм необходима логическая память, а для запоминания лексики - механическая.

Обучение взрослых людей должно строиться с применением различных источников информации - устных и письменных, озвученных и напечатанных текстов, различных упражнений.

Любопытство рождает интерес, в процессе игры обучающиеся неоднократно выполняют задания, не испытывая при этом скуки, не занимаются заучиванием и зубрежкой. Важнейшая функция игр заключается в формировании позитивного отношения к языку, у студента складывается впечатление, что изучение китайского языка - это весело, это интересно, это познавательно.

Практика обучения иностранным языкам показала, что применение принципа наглядности дает наибольший эффект в случае планомерного и систематического его использования. Оно должно соответствовать, вопервых, этапам становления речевого механизма, а во-вторых - должно быть организовано в соответствии с основными частями содержания процесса обучения. Аудитивные средства являются незаменимыми на этапе освоения фонетической системы китайского языка, для ориентировки в системе тонов, представляющих сложность для иностранцев, изучающих этот язык. Они создают ориентировочную основу фонетического оформления звука, слова, фразы.

В ходе обучения аудитивные и визуальные средства обучения по отдельности и в комбинации играют специфические роли при решении конкретных задач.

К таким аудиовизуальным средствам обучения, применяющимся на занятиях китайского языка (особенно на начальном этапе обучения), относятся и так называемые «говорящие картинки» - специальное ТСО, предоставляющее возможность озвучивания иероглифов, фраз, предложений и даже картинок! - которые озвучиваются посредством специального стилуса (Стилус Shifu). 
References:

[1] Картузов А.В. Интерактивные средства обучения в образовательном процессе // Ярославский педагогический вестник. 2009г., № 3. С. 60-63.

[2] Терехова,瓦В. Символ-хронотоп «чжун» в китайской философской традиции [Текст] / Н.В. Терехова // Вестник ИГЛУ. Серия Филология. 2012. №4(21). С. 103109. 


\title{
THEORETICAL AND PRACTICAL ASPECTS OF INTENSIVE TRAINING FOR ARABIC LANGUAGE
}

\author{
K. Kadyrova ${ }^{1}$
}

\section{Abstract}

The article considers theoretical and practical aspects of intensive teaching of the Arabic language. The training of graphics is associated with the mastery of the sound and letter relations and the establishment of connections between the various functional variants of each letter. Active methods of teaching are activities that require creative approach to the material and create optimal conditions for independent work: role-playing, business games, various types of discussions, creative projects, work with sources.

Keywords: innovations, sound-letter relations, graphical skill.

Арабский язык относится к группе семитских языков и является официальным языком двадцати двух стран Аравийского полуострова, Северной Африки и Ближнего Востока. Каждая из арабских стран имеет свои своеобразные особенности: экономику, государственное устройство, географию, историю, культуру, образование, национальные традиции, диалекты и т.д. Поэтому страноведение арабских стран и арабский язык можно считать различными дисциплинами в структуре содержания и филологической подготовки будущих специалистов. Крупнейший представитель испано-магрибской научной школы Ибн Халдун $(1332$ - 1406) в своём историко-философском трактате «Мукаддима» обращал внимание на особую сложность восприятия и изучения арабского языка иностранцами: «Для тех, кто наиболее далёк от пользования арабским языком, усвоение его наиболее трудно»

В процессе изучения арабского языка, как и любого восточного, а значит весьма сложного языка в принципе, отношение студентов к его овладению меняется неоднократно. Ведь далеко не сразу удаётся достичь результата: научиться читать, либо говорить на языке. А сухая грамматика, требующая немалого упорства и терпения, ещё не рисует отчётливой перспективы овладения живым, разговорным языком.

Основные цели, которые ставятся перед студентами на начальном этапе обучения арабскому языку, можно суммировать следующим образом: научиться правильному произношению арабских звуков и их написанию; уметь читать, понимать и переводить без помощи словаря текст, построенный на изученном лексическом и грамматическом материале; отве-

${ }^{1}$ Kamola Kadyrova, associate professor of the Department of Oriental Languages, Faculty of Translation Theory and Practice, Uzbek State University of World Languages, Tashkent, Uzbekistan. 
чать на вопросы преподавателя на арабском языке; ставить вопросы и отвечать на вопросы (в связи с пройденными темами) в устной и письменной форме; уметь устно переводить с арабского языка на родной язык и с родного языка на арабский язык предложения или текст, построенные на изученном грамматическом и лексическом материале; делать устное сообщение и вести беседу на арабском языке; понимать основное содержание учебных текстов, построенные на знаковом языковом материале.

Действительно, современная модель использования инновационных решений, подразумевающая применение компьютерных технологий при проведении лингвистических изысканий, обеспечивает получение объективных качественно-количественных характеристик, подтверждающих обоснованность того или иного научного вывода. Альтернативные методы традиционно базируются на эмпирических данных. Приведем несколько примеров.

В основе орфографии арабского языка лежит практически полное соотношение фонетического, морфологического, идеографического и традиционного принципов. Это, несомненно, облегчает процесс обучения арабскому Обучение технике письма разделяется на научение графике, каллиграфии и орфографии. Обучение графике связано с овладением звуко-буквенными отношениями и установлением связей между различными функциональными вариантами каждой буквы. При обучении каллиграфии на первый план выдвигается задача правильного начертания букв и различимости письма. Обучение каллиграфии опирается на навыки, приобретённые в родном языке. Например, учащимся (студентам) уже известен ряд правил, регулирующих осуществление письма (положение рук, тетради и т.д.). Однако при обучении каллиграфии арабского языка наблюдаются следующие особенности: традиционный принцип правописания справа налево; специфическое написание арабских букв в изолированной форме, в начале, середине и конце слова. Поэтому написание всех букв арабского алфавита требует специальной тренировки. Для овладения начертанием этих букв определённую роль играет их презентация. Целесообразно в процессе обучения письму демонстрировать как написание букв в изолированном виде, обращая особое внимание на отдельные элементы, так и их написание в словах. письму.

Таким-образом, особенности графического навыка в том; что он имеет комплексный характер. Это означает, с одной стороны, двигательный навык, т.е. действие, которое реализуется, на первый взгляд, лишь мускульными усилиями. С другой же стороны, в процессе письма осуществляется перевод осмысленных единиц речи в графические знаки. Это придает письму характер сознательной деятельности. Сознательный характер письма как специфической человеческой деятельности и составляет главное ядро навыка письма. Комплекс навыков письма составляет коммуникативное умение письменной речи, используемой для передачи в письменной форме собственных мыслей, намерений пишущего. 
Другой пример касается непосредственно арабского языка. Известно, что одной форме единственного числа имени в арабском языке может соответствовать несколько форм множественного числа. Однако остается вопрос относительно специфики употребления каждой из этих форм:

KāTiBun - единственное число;

KāTiBūna - множественное число;

KuTTāBun — множественное число.

Активными приемами обучения являются виды деятельности, которые требуют творческого подхода к материалу и создают оптимальные условия для самостоятельной работы: ролевые, деловые игры, различные виды дискуссий, творческие проекты, работа с источниками. Студенту должно быть интересно учиться, познавая нечто новое для себя. Не нужно бояться включать в процесс обучения игровые моменты. Например, в рамках диалогических текстов обыгрываются различные бытовые ситуации: посещение магазинов и общение с торговцами; бронирование гостиничного номера по телефону, заказ авиабилетов и прочие ситуации, призванные развивать практические языковые наработки, которые могут быть реально применены студентами во время учебной практики. А также во время поездки на Ближний Восток для работы или в качестве туристов.

Существует целый ряд общеизвестных способов преподавания арабского языка. Главными из них являются два: «раздельный», когда вычленяется каждый отдельный элемент языка: чтение, письменная и устная речь, орфография, грамматика и проч. и идёт подготовка по ним по отдельным программам и учебникам, и способ «объединённый», его ещё называют «традиционным», это когда язык рассматривается как явление и выступает как единый предмет освоения.

Использование на занятиях по арабскому языку таких технологий обучения как проектирование, организация ролевого общения и подготовка презентаций показывает их эффективность, помогает творческой переработке усвоенного материала при личностной и деятельной ориентации процесса обучения. Данные приемы способствуют не только овладению системой лингвистических знаний и закономерностей функционирования изучаемого языка, его функциональных разновидностей, развитию умений работы с компьютером, получения, анализа и переработки информации из глобальной сети, но и развитию личности обучаемого, раскрытию его творческих способностей, самостоятельности мышления.

Формы работы с компьютерными обучающими программами на уроках арабского языка включают: изучение лексики, отработку произношения, обучение диалогической и монологической речи, обучение письму, отработку грамматических явлений.

Таким образом, из вышеизложенного следует вывод о том, что налицо проблема формирования мотивации, или, проще говоря, устойчивого интереса студентов к изучению арабского языка. Нужно стремиться к тому, чтобы студенты могли осваивать на языке носителей определённые учебные дисциплины арабских университетов, а не просто изучать язык в развёрнутых при них центрах подготовки по языку. 
References:

[1] Берникова О.А. Инновационные тенденции развития арабистики: принципы и методы лингвистического анализа // Материалы конференции «Россия и арабский мир: к 200-летию профессора Санкт-Петербургского университета шейха Ат-Тантави». Санкт-Петербург: 2010. 914 с. С. 227-228.

[2] Батышев, С.Я. Научная организация учебно-воспитательного процесса / С.Я. Батышев. М.: Высш. школа, 1980. 456 с.

[3] Гадамер Х.Г. Истина и метод. М., Прогресс, 1988. С. 700. 


\section{Yu. Zhumanazarova ${ }^{1}$}

Abstract

The article deals with the application of the so-called "creative workshops" in the teaching of the Chinese language. The most important principle assumes that learning a foreign language should have a "communicative direction". Scientists have long proved that in order to teach a person to communicate in a foreign language, he needs to purposefully teach four separate types of speech activity.

Keywords: communicative orientation, mini-project training, speech activity.

Содержательный аспект речи должен формировать у студента представление о том, что изучаемый язык - это не только и не столько набор грамматических правил и условий их применения, правильная фонетика, а еще и средство, при помощи которого слушающему сообщается определенная информация.

С точки зрения методов преподавания китайского языка (КЯ) как иностранного языка с учетом национально-культурных особенностей наиболее эффективным является метод мини-проектов, который мы рассмотрим подробнее. Метод «мини-проектного обучения» включает в себя три основных вида деятельности обучающихся, а именно: сбор информации, формирование своей точки зрения, вывод. Основной задачей этого метода является поиск решения на поставленный перед обучающимся вопрос или проблему.

Алгоритм действий должен быть следующим:

1) Предоставить студенту объявление о приглашении на работу.

2) Студент прослушивает или читает самостоятельно данное объявление.

3) Формирует поведение интервьюера, пришедшего на работу, основываясь на данных, указанных в объявлении, осуществляет поиск способов решения этой проблемы и объясняет причины выбора того или иного способа.

Обучающийся в процессе реализации проекта, преодолевает несколько этапов:

1. Предмини-проектный период, включающий в себя ознакомление с задачей или темой.

2. Процесс осуществления, включающий в себя осуществление задания, создание плана и доклад.

1Yulduzhon Zhumanazarova, a senior teacher, Department of Oriental Languages, Uzbek State University of World Languages, Tashkent, Uzbekistan. 
3. Постмини-проектный период, непосредственно обращение к языковой практике, включающий в себя детальный языковой анализ и практику.

Преподаватель, который применяет информационно-коммуникационные технологии и цифровые образовательные ресурсы, не только творчески развивается сам, но и помогает раскрыть творческий потенциал студентов, соответствует требованиям современного образовательного и воспитательного процесса.

Самый важный принцип предполагает, что обучение иностранному языку должно иметь «коммуникативную направленность». Это означает, что процесс обучения должен быть организован так, что в результате обучающиеся могли использовать иностранный язык для общения, а вовсе не для чтения журналов или текстов на вэньяне. Этот принцип еще называют «речевая направленность».

Обязательная коммуникативная направленность в обучении китайскому языку предопределяет выделение четырех видов речевой деятельности: аудирования (понимание на слух), говорения, чтения и письма. Следующий принцип, который стоит рассмотреть, так и называется: «выделение и взаимодействие всех видов речевой деятельности». Как показал мой личный опыт изучения и преподавания КЯ, следование именно этому принципу удается с наибольшим трудом. Говоря простыми словами, ученые уже давно доказали, что для того, чтобы научить человека общаться на иностранном языке, его нужно целенаправленно обучать четырем отдельным видам речевой деятельности. Но только так, чтобы все это происходило в системе и было связано между собой.

В частности, неудачным примером попытки соблюдения этого принципа является выделение в китайских вузах таких аспектов, как 精读, 阅读 , 口语, 听力, 写作. Идея, конечно, хорошая, но сущности китайцы не уловили.

Поясню, как происходит обучения в китайских вузах. На 精读 акцент делается на обучение грамматике и словам, учебник по 阅读 состоит только из упражнений на чтение, 口语 предполагает обучение только говорению и предпоследний в списке 听力, соответственно, только слушанию. Но все эти предметы ведут разные преподаватели и используют разные учебники. Китайцы, разрабатывавшие когда-то это систему, забыли самое главное. Да, они выделили основные виды речевой деятельности, но эта система категорически не обеспечивает взаимодействие, а значит - неэффективна.

Если бы они не хотели нарушать данный методический принцип, китайским вузам пришлось бы отказаться от всех учебников кроме «精读», а на каждом из аспектов обеспечить работу с одним и тем же языковым материалом в рамках общей темы. 
Пример. Допустим, один раздел (урок) учебника посвящен китайской еде. Если следовать принципу выделения и взаимодействия всех видов речевой деятельности, то на уроках 精读 следовало бы обеспечить знакомство с языковым материалом (новая лексика и грамматические конструкции), а на уроках 阅读, 口语, 听力 и 写作 一 прочное усвоение этого же самого материала и развитие у учащихся сначала навыков, а потом речевых умений. Соответственно:

- на 听力 задачей урока будет научиться слышать и понимать те или иные (в зависимости от программы) тексты по теме урока, содержащие уже знакомую после 精读 лексику и грамматику

- на 口语 целью занятий должно стать обучение студентов речевым действиям, например, заказ еды в ресторане или диалог о вкусовых предпочтениях (в зависимости от программы), но опять же, с использованием все той же лексики, что и на 精读 и 听力

- на уроках 阅读 и写作 студенты должны, как вы, наверное, уже догадались, учиться читать тексты в рамках общей темы и писать, используя языковой материал урока (в идеале - формировать умение читать и понимать меню)

Еще один из основополагающих принципов, который достоин упоминания, носит название «апроксимации». Сложное определение сводится к тому, что можно и нужно игнорировать те ошибки в речи учащегося, которые не мешают достижению цели его высказывания.

Среди различных современных методик обучения иностранному языку особо можно подчеркнуть так называемые «творческие мастерские», которые развивают креативность у обучающихся китайскому языку.

Вначале работы разрабатывается план мастерской, где:

1. Ввод в мастерскую. «Мастерская» - что это такое? Смысл понятия «мастерская».

2. Историческая справка.

3. Технология построения мастерской.

4. Типы мастерских.

5. Принципы и правила проведения мастерской.

6. Этапы работы мастерской.

7. Подведение итогов (рефлексия):

1) затронула ли вас тема обсуждения?

2) какие вопросы были наиболее интересными?

3) попытайтесь кратко сформулировать ваше отношение к данному вопросу (заполнение анкет).

Описание мастерской.

1. Творческая мастерская

Привлекательность мастерской заключается в том, что деятельность участников направлена на познание, поиск ответов на интересующие во- 
просы. Мы понимаем мастерскую как форму обучения учителей и учащихся, которая создает условия для восхождения каждого участника к новому знанию и новому опыту путем самостоятельного или коллективного открытия.

2. Историческая справка

В педагогической науке существует много педагогических технологий, одной из них является мастерская. Мастерская - одна из основных обучающих форм, которые применяются французской группой нового образования - добровольным творческим объединением ученых и практиков Франции, возникшим в 20 гг. XX века. В своей работе мастерская реализует следующие цели: разработка и внедрение в практику образования интенсивных методов обучения и развития. В Россию эта технология пришла в 90-е годы двадцатого века. Педагогическая мастерская - это средство передачи учителем концептуальной и практической сторон своей педагогической системы.

3. Технология построения мастерской

Педагогическая мастерская - форма сотрудничества, которая объединяет все направления педагогической деятельности: от ученичества до мастерства.

Это одна из интенсивных технологий обучения, включающая каждого из его участников в «самостроительство» своих знаний через критическое отношение к имеющимся сведениям, к поступающей информации и самостоятельное решение творческих задач. Из действующих педагогических методов работы мастерская приближается к исследовательским и проблемным методам обучения. Но проблемное обучение в основном опирается на логические противоречия и связи, а творческий процесс в мастерской основан на чередовании бессознательного или осознанного не до конца творчества и последующего его осознания. В системе мастерских все проблемы выдвигаются участниками. В ней важен сам процесс творчества.

References:

[1] Баклашкина М.В. Обучение иноязычному межличностному общению на занятиях по иностранному языку в школе и вузе // Иностр. языки в школе. 2009. № 1. С. 9-13.

[2] Пассов Е.И. Основы коммуникативной методики обучения иноязычному общению. М.: Русский язык, 1989. С.32. 


\section{PSYCHOLOGY}

\section{DIFFICULT BEHAVIOR OF CHILDREN WITH DISABILITIES IN FOSTER FAMILIES}

\section{Aslamazova ${ }^{1}$}

\section{Abstract}

The article is devoted to the difficult behavior of foster children with disabilities, which often arise in foster families and can lead to secondary returns. There was made an attempt to examine the content and nature of behavioral difficulties. Considered in terms of both foster parents and experts.

Keywords: foster family, foster children, difficult behavior, problems in development.

Воспитание приемных детей всегда было нелегким трудом. Особенно сложной представляется ситуация замещающей заботы о детях-сиротах и детях, оставшихся без попечения родителей, имеющих те или иные проблемы в развитии. Обращаясь за консультативной помощью в Службу сопровождения замещающих семей, замещающие родители предъявляют множество жалоб на поведение своих воспитанников, в связи с чем возникает насущная необходимость изучить содержание этих недовольств и характер основных трудностей.

Наше исследование проводилось на базе Службы сопровождения замещающих семей Государственного бюджетного учреждения Республики Адыгея «Центр психолого-педагогической, медицинской и социальной помощи». В нем приняли участие 120 замещающих родителей в возрасте от 31 до 63 лет, воспитывающих приемных детей с ограниченными возможностями здоровья (OB3) более 3х лет. Их воспитанники имеют различные соматические и/или психические нарушения (задержку психического развития, умственную отсталость, заболевания системы кровообращения, дыхания, пищеварения, заболевания органов зрения, иммунодефицит, обусловленный инфицированностью, например, туберкулезом, и др.). В исследовании нами использовались следующие методы и методики: интервью и анкетирование замещающих родителей, экспертный опрос. В роли экспертов выступили специалисты Службы сопровождения замещающих семей, а также педагоги и психологи образовательных учреждений, которые посещают приемные дети.

Большинство замещающих родителей детей с ОВ3 отмечают наличие сложностей во взаимодействии с детьми в процессе их воспитания. Оцени-

\footnotetext{
${ }^{1}$ Liliya Aslamazova, Adyghe State University, Russia.
} 
вая проблемы, возникающие в процессе воспитания, замещающие родители указывали на следующие: трудности у воспитанников в построении взаимоотношений с окружающими, в т. ч. и с членами замещающей семьи (27\%); лживость приемных детей (24\%); трудности в усвоении школьной программы, нежелание учиться (21\%); частые болезни (20\%); упрямство (18\%); воровство (17\%); необученность социально-бытовым навыкам (14\%); повышенная конфликтность (16\%); игнорирование запретов, правил (12\%); замкнутость (11\%); порча вещей (8\%); побеги из дома, бродяжничество (7\%); отсутствие моральных регуляторов поведения (6\%); сквернословие (5\%); токсикомания (2\%).

Примечательным является тот факт, что все замещающие родители приемных детей с ОВЗ были осведомлены о проблемах и сложностях, связанных с их воспитанием, т.к. они проходили обучение в школе приемных родителей, а также получали информацию об особенностях детей-сирот и сложностях взаимодействия с ними от специалистов органов опеки, персонала интернатных учреждений, специалистов службы сопровождения замещающих семей.

Вместе с тем, многие (68\%) замещающие родители приемных детей с ОВЗ отметили, что совершенно не ожидали таких именно трудностей. Несмотря на прохождение курсов подготовки и многократное консультирование, далеко не все замещающие родители оказываются психологически готовыми к приему в семью ребенка-сироты, тем более, ребенка, имеющие особенности в развитии, что приводит к недооцениванию серьезности состояния воспитанника, расхождению между ожидаемыми отношениями и реально складывающимися. Это лишь создает дополнительные сложности в воспитании приемных детей, которые могут приводить к их возврату в интернатное учреждение.

Согласно докладу Комитета по вопросам семьи, женщин и детей Государственной думы Российской Федерации наиболее частыми причинами отказа являются неблагоприятный внешний вид, развитие, поведение приемного ребенка (29\% возвратов), много проблем со здоровьем у него (18\%), плохая наследственность (с точки зрения родителей) (10\%), серьезные конфликты в семье в связи с приемом детей (10\%), неуверенность в собственной компетентности в качестве замещающего родителя (6\%), негативное влияние приемного ребенка на родных детей (5\%) [1]. А также к причинам возвратов можно еще добавить разочарование в приемном ребенке, проблему изначальной мотивации приема, психологическую несовместимость приемного ребенка и замещающего родителя, трудности переходного возраста воспитанника, усугубление отклонений в развитии [2; 3].

Причины трудностей замещающие родители склонны видеть в негативном прошлом своих приемных детей, включая отрицательное влияние жизни в интернате (29\%), наличии отрицательных личностных качеств у их воспитанников (18\%), трудностях подросткового возраста (12\%), негативном влиянии кровной семьи приемного ребенка (4\%). Примечательным является то, что только 7\% замещающих родителей связывают воспитательные трудности с особенностями развития приемных детей с ОВ3. 
Согласно результатам опроса экспертов, положительное отношение к приемным детям с ОВЗ было отмечено у 68\% замещающих родителей. Их отношение характеризовалось эмоциональной близостью, теплотой общения, заботливостью, заинтересованностью. 32\% замещающих родителей, по словам экспертов, нейтрально относятся к своим воспитанникам. Негативного отношения к приемному ребенку отмечено не было. Такие параметры отношения к воспитаннику, как забота о его физическом состоянии, развитии и образовании отмечались у большинства родителей.

Вместе с тем, 87\% замещающих родителей склонны чрезмерно контролировать детей с ОВЗ. Специалисты указали следующие особенности отношения родителей к приемным детям: повышенная строгость (у 23\% родителей), частые высказывания недовольства и наказания (14\%), постоянные жалобы (12\%), дистанцированность в общении (10\%), акцентирование внимания на его неудачах (4\%), проявление эмоциональной холодности $(2 \%)$.

Наряду с негативными проявлениями в отношении к приемным детям, нередко наблюдаются и прямо противоположные черты, связанные с потворствованием: 24\% замещающих родителей потакают желаниям приемных детей, $16 \%$ не могут отказывать своим воспитанникам и запрещать им что-либо, 10\% воспитателей стараются все делать за них (делают уроки, оберегают от домашней работы, негативных переживаний и т.д.).

Характеризуя отношение приемных детей с ОВЗ к замещающим родителям, эксперты указали, что $90 \%$ из них положительно относятся к своим родителям (проявляют привязанность, теплые чувства, принимают родителей, беспокоятся о них, помогают, любят вместе с ними проводить время) и у $10 \%$ отмечается нейтральное отношение. Негативного отношения отмечено не было.

Вместе с тем, эксперты указали на негативные проявления, которые присутствуют в отношении приемных детей к родителям (в основном у детей с нейтральным отношением): проявление агрессии (у 16\% приемных детей), страх (9\%), отсутствие интереса к родителю (8\%), эмоциональная холодность (8\%), жалобы на родителя (4\%), избегание общения с ним (2\%). Специалисты также указали, что 48\% воспитанников с ОВ3 демонстрируют иждивенческое отношение к замещающим родителям и их семьям, 26\% из них открыто требуют заботы о себе, манипулируя этим для достижения своих целей.

По словам экспертов, основными трудностями, возникающими в замещающих семьях с приемными детьми с ОВ3, являются недостаток взаимопонимания между родителями и воспитанниками, сложности взаимопринятия, формирования и развития привязанности друг к другу, нехватка эмоциональной теплоты общения и сотрудничества в деятельности.

Пути преодоления сложившихся трудностей специалисты видят в учащении совместной деятельности замещающих родителей и приемных детей, расширении форм организации семейного досуга для всех членов семьи, участие в тренингах, повышающих эффективность детско-родитель- 
ского взаимодействия, проведение для родителей семинаров по проблемам принятия неродных детей с ОВ3, обмен опытом с другими замещающими родителями, своевременное обращение за психологической помощью.

Оценивая особенности детско-родительских отношений в замещающих семьях с приемными детьми с ОВ3, эксперты считают, что в $71 \%$ семей сложились благополучные, теплые, близкие отношения между родителями и воспитанниками; в $27 \%$ семей - недостаточно хорошие отношения, с нехваткой эмоционального тепла и близости, временами конфликтные и напряженные; в 2\% семей - плохие отношения, с эмоциональным отвержением ребенка. Случаев жестокого обращения отмечено не было.

Таким образом, экспертная оценка подтвердила наличие целого ряда трудностей в замещающих семьях, воспитывающих детей с ОВЗ. Стоит отметить, что большинство указанных проблем связаны не только с психологическими особенностями детей-сирот, но и со спецификой системы взаимоотношений, складывающейся во многих замещающих семьях, характеризующейся недостатком взаимопонимания между родителями и детьми, взаимопринятия, привязанности друг к другу, сотрудничества, а также с повышенным родительским контролем, строгостью, дистанцированностью в общении с воспитанниками, выражением недовольства ими либо потворствованием в удовлетворении их потребностей.

References:

[1] Monitoring of the situation of orphans and children left without parental care, and the development of family forms of their devices in the Central Federal District in 2008 (the third annual report) / Comp. Semiya G.V., Zaitsev G.O., Zaitseva N.G.; Ed. G.V. Semiya. M.: 000 "Variant", 2009. 180 p.

[2] Mitireva 0. Return of a foster child Part Two (causes and prevention). URL: http://adoptlaw.livejournal.com/18246.html (reference date: 14.11.2016).

[3] Osipova I.I. The phenomenon of secondary orphanhood in modern Russia // Detskii dom. 2009. 1. № 30. P. 14-19. 


\section{PROFESSIONAL CONSCIOUSNESS AS A COMPONENT OF AN IMAGE I}

\section{A. Klimanova ${ }^{1}$, N. Ezhkova ${ }^{2}$}

\section{Abstract}

The article presents the scientific analysis of the problem of interrelation of professional identity and image J. Describes key components of the structure of professional self-consciousness, reveals the structural components of the world, I-man and his professional development.

Keywords: identity, professional identity, self-concept, self - concept, structure of professional identity.

Проблема профессионального развития педагога, фундаментальным условием которого является повышение уровня его самосознания, нашла отражение в целом ряде отечественных и зарубежных психолого-педагогических концепций профессионального образования. Профессиональное самосознание педагога рассматривалось как базовая составляющая педагогической деятельности, как компонент профессионального становления и развития (Е.И. Исаев, Ю.Н.Кулюткин, Л.М. Митина и др.) [3].

Самосознание сложная категория, она неразрывно связана с процессом построения и коррекции образа "Я". Знания о самом себе человек получает путем анализа ситуаций, в которых оказывается, их рефлексией и анализом. Отношение личности к другим и отношение общества к личности в ситуации согласия, препятствий, конфликта, кризиса способствуют организации мышления о самом себе, постижению своего внутреннего "Я". Через оценки и ценности других людей, включенных в отношения личности, субъект приобретает свое место, статусное положение своего "Я" в обществе. Как характеризует и переживает самого себя в качестве носителя систем социальных отношений, своеобразного социального объекта, по какой внутренней структуре построены когнитивные элементы самопонимания, какую природу имеют отправные социальные точки самопонимания, т.е. прежние включения в социальные группы (самоотождествление с социальными группами разного типа), как они представлены в самосознании - все это составляющие большого мира Я-человека и его профессионального развития [4].

Большинство отечественных исследователей (Е.М. Васильева; В.Н. Козиев; Л.М. Митина) и некоторые зарубежные психологи (Т. Макклапаред,

\footnotetext{
${ }^{1}$ Alina Klimanova, graduate student, Tula State Lev Tolstoy Pedagogical University, Russia.

${ }^{2}$ Nina Ezhkova, professor, Doctor of Education, Tula State Lev Tolstoy Pedagogical University, Russia.
} 
М. Кун) предполагают, что профессиональное самосознание - это установка на себя в профессионально-трудовой сфере. И как любая установка, самосознание имеет когнитивную, аффективную и поведенческую подструктуру (Я-понимание, Я-отношение, Я-поведение). Следовательно, ключевыми компонентами структуры профессионального самосознания являются компоненты, которые характеризуют когнитивный, аффективный, поведенческий уровни и процессы профессиональной идентификации, как ключевые механизмы интеграции "профессионального Я" [5].

Соотношение понятий образа «Я» и самосознания точно не определено. В ряде работ они выступают как синонимы. Вместе с тем, существует тенденция рассматривать Я-концепцию как результат, итоговый продукт процессов самосознания.

В «образ профессионала» входит и чаще всего оказывается самым главным «образ себя в профессии» (как я буду себя вести, какие я проявлю способности и добьюсь ли большого успеха, какой я буду «важный», или «влиятельный», или «значительный» в этой профессии, какие «важные» и интересные люди меня будут окружать) [1].

А. В. Прудило представляет структуру профессионального самосознания через:

1. «Образ Я» - самопонимание, определение себя в собственных ценностях и смыслах, потребностях и мотивах, личностных особенностях.

2. «Образ профессии» - понимание профессии, осознание ее различных сторон.

3. «Образ Я в профессии» - осознание себя в профессии, готовность осуществить данный выбор и предпринять усилия по его реализации [2].

Высокий уровень развития профессионального самосознания характеризуется в когнитивном компоненте наличием знаний о своей профессиональной деятельности, представлений о себе в контексте данной деятельности, образ «Я-профессионал» интегрирован с «Я-концепцией». В аффективном компоненте - это положительное отношение к себе, адекватная профессиональная самооценка. Поведенческий компонент характеризуется наличием мотива к самоактуализации, стремлением к саморазвитию [5].

Профессиональное самосознание включает оценку имеющихся достижений, планирование направления саморазвития, его осуществление и т.д. Только в том случае, если педагог знает, с одной стороны, какими качествами он должен обладать, а с другой - сознает, в какой мере у него развиты данные качества, он может сознательно стремиться к развитию данных качеств у себя. Соответственно, в структуре педагогического профессионального самосознания выделяются: «актуальное Я» (центральный элемент) - каким себя видит и оценивает учитель в настоящее время; «ретроспективное Я» - каким себя видит учитель по отношению к предыдущим этапам профессиональной деятельности. Отношение к «актуальному Я» дает учителю шкалу собственных достижений; «идеальное Я» - каким бы учитель хотел стать. Оно является ценностной перспективой личности, 
обуславливает саморазвитие личности в профессиональной сфере; «зеркальное Я» - как, с точки зрения учителя, его рассматривают и оценивают другие люди, например коллеги, учащиеся [3].

Процесс формирования профессионального самосознания предполагает постоянное изменение и углубление Я-образов будущего субъекта профессиональной деятельности под воздействием приобретаемых новых профессионально-личностных и индивидуально-психологических качеств, совершенствования профессиональной деятельности, приобретенных профессиональных знаний и представлений, в том числе и профессионально-психологических. Сформированность образов «Я - реальный специалист» и «Я - идеальный специалист» обусловливается полнотой осознания и принятия учащимися профессионально-психологических знаний и требований, предъявляемых профессией к личности специалиста.

Профессиональное самосознание и его развитие важное направление педагогики и психологии профессионального образования, которое должно исследоваться и как компонент образа Я. Именно этот ракурс - взаимосвязь профессиональное самосознания и образа Я - требует, на наш взгляд, специального теоретического обобщения и экспериментального анализа.

References:

[1] Бернс Р. Развитие Я концепции и воспитание. М.: Прогресс, 1986. 336 с.

[2] Елдышова 0.А. Профессиональное самосознание как психологическая составляющая профессионального становления. //Фундаментальные исследования. 2006. № 7.196 c.

[3] Матвиевская Е.Г. Профессиональное самосознание педагога как основа формирования культуры оценочной деятельности в системе повышения квалификации // Теория и практика образования в современном мире: материалы Междунар. науч. конф. (г. Санкт-Петербург, февраль 2012 г.). СПб.: Реноме, 2012. С. 392-396.

[4] Протасова Н.И. Развитие самопонимания юношей и девушек в процессе профессиональной подготовки будущих учителей. Астрахань, 1999. 196 с.

[5] Эннс Е.А. Понятие профессионального самосознания в психологической науке // Психологические науки: теория и практика: материалы Междунар. науч. конф. (г. Москва, февраль 2012 г.). М.: Буки-Веди, 2012. С. 127-129. 


\title{
METHOD OF STUDIYING INTERPERSONAL FEEDBACK \\ IN BUSINESS COMMUNICATION
}

\author{
A. Belov ${ }^{1}$ \\ DOI: http://doi.org/10.15350/L_26/9/4
}

\begin{abstract}
In the article is scrutinized the problem of analyzing the feedback supply in the context of business communication between company employees and customers. A brief theoretical overview of feedback problems in interpersonal communication is provided, as well as experience in the development of psychological analysis methods of the feedback with the example of the grid content analysis of the dialogue partners statements.
\end{abstract}

Keywords: Business communication, feedback, interpersonal feedback, dialogue, employee, customer, content analysis, feedback classification.

At the present time the view of business as a partnership system is considered to be the most promising. In this regard, business communication studies become of particular relevance and importance, which reveals the communication partners relationship specifics and performance characteristics of their interaction. In soviet and Russian social psychology were developed theoretical propositions about the functions, role and structure of communication (G.M.Andreeva), the kinds of communication and feedback supply (L.A.Petrovskaya), the feedback characteristics (O.V.Soloveva). Various experimental studies have investigated the aspects of feedback in interpersonal communication (N.V.Antonova, A.B. Belov, N.S. Zhuravleva, M.A. Ladionenko, E.N. Stremousova et al.). On this basis, we developed an author's method of studying the feedback in business communication.

According to the methods for transmitting feedback can be divided into direct and hardware, mediated by various technical means (camera, tape recorder, video camera, a movie camera, and so on). By type of device feedback can be divided into communicator-subject and the communicator-object. In the first case the feedback source is people (group of people), and in this sense, they play the rope of subject, and in the second case - any other physical reality world. Further, we consider the communicator-subject feedback. For this type, three main types can be distinguished, namely^ the feedback system "the individual - the individual", "individual - group" and "group - a group" [7]. From these three possible combinations precisely the type of "individual - the individual" complies with our study objectives.

Social feedback such as "individual-individual" is usually referred to as interpersonal feedback. It plays a dominant role in the socio-psychological training.

${ }^{1}$ Andrew Belov, PhD Student, Moscow State University, Russia. 
According to the means of transmission, it can be divided into verbal and nonverbal. Also, the feedback can combine evaluation and interpretive components, supplied in the form of advice, suggestions, requests [9]. In addition to the forms, feedback classification can be carried out on the content: about the behavior, psychological state, the result of the action, etc. [4].

As we are studying the situation of business communication in the service company it will supply a priority to intentional verbal feedback, leading to the establishment of trust between the client and the company employee and allowing partners to progress in solving their common business objectives.

The study involved 27 staff members ( 20 men and 7 women), employees of the Russian service company (which sells and services vehicles) between the ages of 20 and 55 years and withexperience in the specialty for at least 1 year. Communication with customers is a major part of their work. Also, the study involved 32 clients of the company: 22 men and 10 women aged from 20 to 66 years.

Surveillance of employees communicating with customers was conducted. Were recorded on tape ten dialogues each employee with customers. To eliminate the influence of factors previously formed personal relationships, were recorded conversations only with those customers who were not previously familiar to employees.

For the analysis of the formal and substantive statements by members during the actual interaction with the client was used a categorical grid developed on the basis of L.A. Petrovskaya approach [8], in a modified in accordance with the purposes of this study variant.

Table 1

Example of a content analysis grid for feedback in business communication

\begin{tabular}{|l|l|l|}
\hline Code & Category & Examples \\
\hline 2 & Feedback & $\begin{array}{l}\text { We've already had two such cases in two } \\
\text { days. You're well done, that as soon as no- } \\
\text { ticed the oil leak, come to us. }\end{array}$ \\
\hline 2B & Descriptive & $\begin{array}{l}\text { I am very glad that you are so lucky with } \\
\text { the car }\end{array}$ \\
\hline 2B & Evaluative & $\begin{array}{l}\text { You did the right thing as soon as noticed } \\
\text { oil leakage came to us. }\end{array}$ \\
\hline 2C & Evaluative \& Interpreting & $\begin{array}{l}\text { You are an educated man, you know, that } \\
\text { where thin, there and tear. }\end{array}$ \\
\hline 2D & Advice & $\begin{array}{l}\text { It is better to come in the next time, we will } \\
\text { then TO1 and TO2 will hold together. }\end{array}$ \\
\hline 2E & Feedback emotional sign & $\begin{array}{l}\text { You're well done, that as soon as noticed oil } \\
\text { leakage came to us. }\end{array}$ \\
\hline 2Ea & Positive + & You spend time my and your in vain. \\
\hline 2Eb & Negative - & $\begin{array}{l}\text { All papers are in order, you have arrived in } \\
\text { time. }\end{array}$ \\
\hline 2Ec & Neutral & $\begin{array}{l}\text { You're well done, that as soon as noticed oil } \\
\text { leakage came to us. }\end{array}$ \\
\hline 2F & $\begin{array}{l}\text { Argument-based } \text { (from } \\
\text { above) }\end{array}$ & \\
\hline
\end{tabular}


Feedback broadly aimed at the content of the message was supplied in all the observed dialogues between customers and employees. Here are some examples:

Customer: Do you have a cabin light bulb?

An employee of the company: What car accessories set do you posess?

Client: Standard one with velour seats.

An employee of the company: Yes, there is one for this configuration.

Feedback in the narrow sense (personal), which is characterized by an orientation on the identity or nature of the communication, was not always observed. Here are some examples of using the feedback in the narrow sense:

An employee of the company: What is your problem with oil dribble?

Client: Here, look, there are very few left, topped up with a liter per 100 kilometers.

An employee of the company: Good job for you, that as soon as you have noticed you came to us. You're just in time: avoid large and expensive repairs (appraisal, positive, reasoned feedback).

An analysis of the employees statements structure in the process of business communicating with customers has shown a significant predominance of substantive statements aimed at the client itself, a car failure, other employees $(60 \%$ of all statements) of the treatment (20\%) and the actual feedback (16\%). In a small number of attributive judgments (4\%) were present in the dialogues. Among meaningful utterances the greatest number belongs to statements pointing out the working process $(30 \%)$. They are more than statements aimed at the client $(25 \%)$, automobile (11\%), self $(10 \%)$, a fault with vehicle $(10 \%)$ at spare parts and supplies (7\%), staff technical center (6\%). Many of these statements are included in the meaningful semantic system applications and requirements, for example, revealing more detailed service rules $30 \%$ of the total number of statements designed to workflow) and organizational - business procedures $(70 \%)$.

Feedback of employees are up to $16 \%$ of the total number of sentences. There were all kinds of feedback: descriptive (example: "We've already had two such cases in two days you done that as soon as noticed the oil leak, come to us"), selfdescriptive (example: "I am glad that you are so lucky with the machine "), evaluative (example:" you have done that immediately came to us "), assessment and interpretive (example:" you are an educated man, you know, that where thin, there and tear "), advice (example: "It is better to come in the next time, we will then T01 and T02 will hold together"). Analysis of all statements of employees, giving feedback to clients, demonstrated the predominance of descriptive feedback ( $47 \%$ of the feedback statements by category) on self-descriptive (24\%), evaluative (5.8\%), assessment and interpretive (4.5\%) and a specific form of advice $(16 \%)$.

Intonation, which with was submitted feedback, was mostly neutral on the emotional character ( $84 \%$ of statements relating to the feedback).

Conclusions

The study showed correspondence between developed studying feedback in business communication technique and our research purposes. The developed 
method allows to fully explore the content and feedback forms, to draw conclusions about the nature of the feedback from employees to customers, and to develop practical recommendations to improve the business communication of company employees with customers.

\section{References:}

[1] Andreeva G.M. Social Psychology: A Textbook for high schools. 5th ed., Rev. and ext. Moscow: Aspect Press, 2004.

[2] Antonova N.V. The identity of the teacher and the features of its communication. Doctoral thesys. Psychol. Sciences. Moscow, 1996.

[3] Belov A.B. Socio-psychological characteristics of the client's perception in business communication // Psychological research. 2012. T. 5, N 25. P. 11. URL: http://psystudy.ru (accessed 10.01.2017).

[4] Zhukov Y.M. Communication skills. Moscow: Gardariki, 2004.

[5] Zhuravleva N.S. Methods of delivery of feedback and its effects in the corporate training. Doctoral thesys. Psychol. Sciences. Moscow, 2004.

[6] Ladionenko M.A. Critical feedback: gender factor in its perception. // Psychology of communication: humanity training: Abstracts of the international scientific-practical conference dedicated to the 70th anniversary of the birth of L.A. Petrovskaya. Moscow: Smysl, 2007. P. $40-42$.

[7] Petrovskaya L.A. Competence in communication: Socio-psychological training. Moscow: Pub. MSU, 1989.

[8] Petrovskaya L.A. Feedback as a phenomenon of social and perceptual processes in the group. // Interpersonal perception in the group. / Ed. G.M. Andreeva, A.I.Dontsov. Moscow: Pub. MSU, 1981.

[9] Solovyova O.V. Feedback in interpersonal communication. Moscow: Pub. MSU, 1992.

[10]Stremousova E.N. Characteristics of feedback in personal and business communication in the organization. // Psychology of communication: humanity training: Abstracts of the international scientific-practical conference dedicated to the 70th anniversary of L.A. Petrovskaya. Moscow: Smysl, 2007. P. 50 - 52. 


\section{THE INFLUENCE OF R. WAGNER'S MUSIC ON THE WORK OF THE ENGLISH WRITER K.S. LEWIS}

\section{Efimova ${ }^{1}$}

\section{Abstract}

In this article we are talking about the influence of Richard Wagner's music on the formation of artistic and aesthetic views of KS. Lewis.

Keywords: music, mythology, art creativity, faith.

В мировом культурном наследии известны многочисленные примеры вдохновенного влияния музыки на творчество мастеров художественного слова. Не является исключением и Клайв Стейплз Льюис (1898-1963), английский писатель, филолог, христианский проповедник, профессор двух университетов- Оксфордского и Кембриджского, перу которого принадлежат более 40 произведений, среди них «Чудо» (1933), «Аллегория любви» (1936), «Письма Баламута» (1942), «Космическая трилогия» (1938-1945), «Хроники Нарнии» (1950-1956).

Знакомство Льюиса с музыкой Вагнера произошло в период 1911-1913 гг., когда писатель учился в школе в Шербурге. По признанию Льюиса, это было одним из самых ярких моментов Шербургского периода. А произошло это вот как. Однажды Льюис случайно увидел в журнале статью с заголовком «Зигфрид и сумерки богов» с иллюстрацией художника Артура Рекхема. Статья произвела на писателя ошеломляющее впечатление. Позже в своей биографии «Настигнут Радостью» он напишет: «Я ощутил дыхание настоящего севера,.. увидел огромное ясное пространство, дальние пределы Атлантики , сумрачное северное лето, далекое суровое небо, и тут же вспомнил, что уже знаю это давно» [1.T.7. с.322].Ещё раньше отце купил Льюису магнитофон и он с удовольствием слушал музыку Р. Вагнера. Он приобрёл пластинки Вагнера, а именно «Кольцо», «Парсифаль», «Лоэнгрин», «Валькирия» и сам, вдохновленный содержанием и самой музыкой, «написал большую поэму о Зигфриде в четырёх частях [1.T.7, с.322].Чем же так привлекла Льюиса музыка Вагнера? Может быть, «вагнеровские пейзажи, изобразительные страницы его музыки, раскрывшие жизнь леса, воды, облаков, горных вершин, получивших в музыке своё конкретно- зрительное воплощение» [1, c.238]. Или его вдохновили героические устремления персонажей оперы? Ведь недаром писатель говорил, что «ощущает единство Вагнера и «Валькирии», которые были для него не номером, а частью героического действия [1.T.7, с.324].Заметим, что в основу «Валькерии» заложена тема борьбы таинственного порядка со злом, а

${ }^{1}$ Lyudmila Efimova, Candidate of Philology, Associate professor of Department of foreign languages and business communication, Plekhanov Russian Academy of Economics, Russia. 
главным действующим лицом оперы является человек, обладающий свободной волей и выступающий против Предопределения, которое лишает человека свободы выбора и предполагает подчинение року, судьбе.

По мнению музыкального критика Б.Астафьева, обаяние «Валькирии» кроется в трех моментах: «.. любви, сострадании и беззаветного героизма, что и включает в себя образ настоящего человека» [2, с.238]. Можно представить, что Льюиса увлекла личность самого Р.Вагнера, в которой сочетались черты «бунтаря и забияки с романтическим мечтателем» [2, с.239]. Музыка композитора оживляла воображение будущего писателя. Он представлял себе героев всех скандинавских мифов. По справедливому замечанию К. Килби, «все мифы пробудили в нём огромную любовь к природе и музыке, по крайней мере, к музыке Р. Вагнера»[3.p.16].Те, кто хоть однажды слушал музыку Вагнера, вероятно, согласятся с тем, что она привлекает своей контрастностью, юношеским задором, звуковой насыщенностью, нарастающей напряженностью, удивительным разнообразием гармонических решений, стройностью и даже какой- то строгостью симфонического оркестровки, своеобразной динамикой, музыкальной партитурой, внезапной сменой лейтмотивов, не нарушающих, впрочем, законы построения музыкального произведения. И это очень похоже на литературный стиль Льюиса, который отличает многоплановость и полижарновость.

Уместно заметить, что Льюис с особым интересом относился к музыке именно Вагнера, но это некоим образом не повлияло на возникновение у него большого интереса к музыке вообще. По словам писателя, « просто музыка и музыка Вагнера были совершенно разными занятиями, несоизмеримыми» [1.T.7, с 324].Для него Вагнер был не новым родом удовольствия, если можно назвать «удовольствием ту тревогу, тот восторг и изумление, ту битву безымянного чувства» [1.T.7, с.324].Здесь, скорее всего, Льюис имеет в виду свою мистическую встречу с Радостью, которую он потерял в раннем детстве вместе с утраченной верой в Бога, и как бы он впоследствии (до своего обращения) не пытался найти ей замену, он терпел фиаско, потому что ничто не заставило трепетать глубины его сердца, в котором не было места Богу. Как выразился однажды Джордж Макдональд: «Всё, что не Бог - смерть» [4, с.129]. Именно той Радости - «прикосновение перста» - у Льюиса тогда не было.

Знакомство с музыкой Вагнера не прошло для Льюиса даром. Она навеяла на него воспоминания о его счастливом детстве, и, возможно, не дала окончательно погибнуть его эстетическим идеалам. Позволила по- новому ощутить красоту окружающего мира. Льюис так написал об этом: «Возрождённое воображение вскоре подарило мне чувство природы. Сперва это было чистым плагиатом из книг и музыки Летом в Дандраме, касаясь на велосипеде по Виклоуским холмам, я почти бессознательно искал вагнеровский пейзаж: пологий, поросший елями, холм, где Мим мог встретить Зигфрида; солнечную поляну, где Зигфрид мог слушать пение птиц; ущелье, со дна которого поднимается гибкое змеиное тело Фафнира» [1.Т.7, c.325]. Музыка Вагнера позднее дало начало серьёзного увлечение писа- 
теля скандинавской мифологией, «принялся за всё, что мог достать о мифологии», признавая, что «вновь и вновь обретал в этих книгах Радость», хотя она была уже не похожа на первоначальную», ничего духовного в ней почти не было. И скорей всего, это было «интеллектуальное удовлетворение» [1. Т.7, с.326].

Отголоски легенд и мифов, которые легли в основу оперного творчества Р. Вагнера, мы можем найти в литературном творчестве К.С. Льюиса. Так, в романе- притче «Пока мы лиц не обрели» внимательный читатель оценит гармоничную стройность и светлую грусть в тех нежных словах, которые говорит перед смертью Оруаль своей сестре Психее, а читая строки о Нарнии в «Последней битве» можно услышать звучание скрипок из вступления к опере Вагнера «Лоэнгрин», где «сердце тоскует по небу» и наполняется радостью при виде его. И таких литературных примеров из наследия писателя можно привести множество. Внимательное изучение творчества К.С. Льюиса позволило сделать наблюдение о том, что его художественное творчество очень музыкально, динамично по своему характеру, подчинено логично выстроенной композиционной структуре. Недаром в 1962 году, сразу же после смерти Джой, жены К.С. Льюиса, его посетили два композитора, одного из них звали Дональд Суонн, и выразили своё желание написать оперу на сюжет «Переландра». Либретто к опере было которой было написано оксфордским другом Суонна Дэвидом Маршем. Льюис так и не услышал оперу целиком, однако успел прослушать перед своей кончиной два фрагмента и «остался ими очень доволен». [5. с.1] Николай Эппе «Опера по Льюису в Оксфорде»

Итак, можно сказать, что музыка Вагнера, с её глубоко философской симфонией чувств, оказала влияние на формирование художественно- эстетических взглядов К.С.Льюиса. Ведь, по справедливому замечанию митрополита Антония (Сурожского), «музыка способна изменить человека.., через неё он приобщается к тому, «что не умел слышать сам.., в нём самом начинается «процесс познания того, что выше, шире и глубже его самого» [6. T.1, c.718].

References:

[1] Льюис К.С. Собрание сочинений в 8 тт. М., 1998. Т 7. 429 с.

[2] Асафьев, Б.В.Об опере. Л.,1976.-336с.

[3] Kilby, Clyde. The Christian world of C.S. Lewis. Ground Rapid, Mich.: Eerdmans, 1964.$216 \mathrm{p}$.

[4] Крифт, Питер. Трактаты // пер. Траубрег, Н.Л.-М., 2002. 264 с.

[5] Николай Эппе. Опера по Льюису в Оксфорде. http://os.colta.ru/music_classic/events/details/11193/

[6] Антоний, Митрополит Сурожский. Труды. Книга 1. М., 2002. 1148. 


\title{
VARIETIES OF THE GENRE IN K.S LEWIS'S NOVEL "THE SPACE TRILOGY"
}

\section{Efimova ${ }^{1}$}

\begin{abstract}
This article tells about the genre features of C.S Lewis' novel «Space Trilogy» in three parts. Draws Special attention is drawn to the assessment of the genre specificity of the novel by both domestic and foreign specialists in literature, who emphasize the broad range of these estimates, their similarities and differences with the opinion of the flame nature of the novel. In addition, the article describes the literary genres of science fiction and fantasy, and their interpretation by different philological schools and trends, as well as the role of science fiction and fantasy in the disclosure of the characters of the novelis is broadly emphasized.
\end{abstract}

Keywords: literary criticism, genre of fiction, fantasy, romance, fiction literature, specifics of genres.

Роман Клайва Степйплза Льюиса «Космическая трилогия» был написан в 1938-1945 годах. Она включает в себя три книги «За пределы безмолвной планеты», «Переландра», «Мерзейшая мощь». Жанровая специфика трилогии разнообразна и как у западные, так и отечественные литературоведы существуют различные мнения по поводу определения жанра трилогии. Так, Колин Дурье (Colin Durier) в целом считает, что «Космическая трилогия» написана в жанре научной фантастики [1, с.152]. М. Райт (M. Wright) убеждена в том, что трилогия Льюиса представляет жанр фэнтези [2, c.198]. Такого же мнения придерживается Чэд Уолш (Chad Walsh). Автор отмечает, что космос у Льюиса - это сплав современной науки и средневековой космологии [3, с.130.115]. Эдмунд Фуллер (Dr Edmund Fuller) определяет жанр «Космической трилогии» как фэнтези. По мнению критика Дж. Гибба (J. Gibb), трилогия Льюиса представляет научную фантастику [4, c.181]. Дж. Сейер (J. Sayer) характеризует I часть «Космической трилогии» («За пределы Безмолвной Планеты») как роман о космическом путешествии [5 там же, с.181]. Критик приводит высказывание Дж. Оруэлла (George Orwell), считавшего третью часть трилогии «криминальной историей, изрядно испорченной присутствием сверхъестественного». Р. Уильян (R. Willian) отмечает большой вклад Льюиса в развитие жанра

${ }^{1}$ Lyudmila Efimova, Candidate of Philology, Associate professor of Department of foreign languages and business communication, Plekhanov Russian Academy of Economics, Russia. 
фэнтези и определяет жанр «Космической трилогии» как фэнтези [6, с.176178.]. К. Хьюм (К. Hume) называет трилогию Льюиса «cosmic romance»космическим авантюрным романом, отмечая его ярко выраженную теологическую направленность, как и направленность других его произведений.

Как видим, определяя жанр «Космической трилогии» как фантастику или фэнтези, исследователи отмечают наличие библейских мотивов, мифологических сказаний и легенд, а также присущие «Космической трилогии» черты рыцарского романа.

Жанровое своеобразие «Космической трилогии» отмечают и отечественные литературоведы. Так, Е.Н. Ковтун считает, что каждый роман трилогии имеет свою жанровую специфику. Первую часть она определяет как произведение научно-фантастического жанра, во II-ой части она видит синтез двух жанров: рациональной фантастики и фэнтези, где фэнтези отводится ведущая роль. Третья часть, по мнению автора, «представляет собой своеобразную перекличку модели научной фантастики и фэнтези» [7, c.120-121].

Иное определение жанровой природы трилогии дает С.Л. Кошелев. Он называет «Космическую трилогию» «одним из классических образов философской фантастики, где философское построение не затмевает и не вытесняет собственно художественного постижения жизни» [8, c.5].

Н.Л. Трауберг считает жанровой доминантой романов «За пределы безмолвной Планеты» и «Переландра» научную фантастику, а в третьей части «Мерзейшая мощь», вслед за другими исследователями, видит подражание мистическим триллерам Чарльза Уильямса. Самого же Ч. Уильямса Н.Л. Трауберг считает прототипом героя «Космической трилогии» [9, Т.4, c.336].

Сам К.С. Льюис не дает определения жанровой природы своей трилогии, лишь о третьей части упоминает, что это «сказка», подчеркивая в ней роль магии и волшебства.

Особенность жанра научной фантастики составляет, как видно из определений жанра, своеобразие сюжета, хронотопа, системы художественных образов.

Как отмечает литературная энциклопедия терминов и понятий, «термин научная фантастика или S.F. - science fiction - «вид фантастической литературы (или литературы о необычайном), основанной на единой сюжетной посылке (допущение) рационального характера, согласно которой необычайное (небывалое, даже, казалось бы, невозможное) в произведении создается с помощью законов природы, научных открытий или технических изображений, в принципе не противоречащих естественно-научным воззрениям, существующим в то же время, когда создавалось научнофантастическое произведение»[10, стлб.1621]. Science fiction представляет 
мир вероятным, построенным по известным моделям; этот мир является отражением реальности, проблемы фантастического произведения - это актуальные проблемы реальной Вселенной.

По замечанию В.Л. Гопмана, «научная фантастика» - это «не литература идей», сфера ее применения - исследование жизни социума и индивидуума, происходящих в них изменений под действием сдвигов науки и техники» [там же, Стлб.1622-1623]. В качестве литературных примеров автор приводит произведения Т. Мора, Ф. Бэкона, Дж. Свифта.

Н.А. Чернявская и Е.Н. Брандис обращают внимание на роль фантастики в литературе XX века: это «сложное и разветветвленное явление, охватившее все литературные жанры и все виды искусств... ее стремительный взлет с середины столетия и пережитые ею метаморфозы по-своему преломляют необратимые последствия, вызванные научно-технической революцией и грандиозными социальными потрясениями, изменившими за короткий исторический период политическую карту планеты» [11, с.269.]. Авторы обращают внимание на то, что фантастические произведения позволяют по-новому взглянуть на окружающий мир, пережить чувство удивления от многообразия художественных образов. По мнению писателя 0. Неффа, «научная фантастика не только отражает достижения науки, но и сама использует прием экспериментов.... При оценке научной фантастики писатели являются сами участниками этого эксперимента и наблюдают за поведением героев» [12, с.30].

Ц. Тодоров считает, что «в основе фантастического лежат главным образом колебания читателя (отождествляющего себя с главным героем) относительно природы необычного события. Колебания заканчиваются тем, что событие или относят к реальной действительности, или объявляют плодом воображения, результатом иллюзии: иными словами, в конце концов приходят к заключению, что событие было или что его не было. Вместе с тем фантастическое требует определенного прочтения, иначе возникает опасность аллегорического или поэтического его толкования» [13, с.126].

В современном литературоведении в научной фантастике выделяют отдельные виды. Так, Т.Н. Чернышова в работе «Природа фантастики» выделяет следующие ее виды: содержательная утопическая и научно-социальная фантастика (известная со времен Г. Уэллса), научно-техническая фантастика (связана с творчеством Жюль Верна), где исследуются и отображаются социальные характерности человеческой жизни и искусственной среды, второй «природы», в их взаимообусловленности; а также фантастика, которая некоторыми исследователями обозначается как «научнобиологическая» («Человек-невидимка» Г. Уэллса, «Человек-амфибия», «Голова профессора Доуэля» А. Беляева и др.)» [14, с.369].

Е.Н. Ковтун выделяет особую «рациональную фантастику», проявляющуюся в особом мироощущении [15, с.91]. 
Сам Льюис предлагает свою классификацию видов фантастической литературы, выделяя четыре ее вида:

1. пророческая фантастика: здесь предметом критики является реальная действительность, а фантастическая действительность рассматривается как образец жизнеустройства;

2. инженерная фантастика (fiction of Engineers), связывающая будущее человечества с техническими достижениями. Такая литература широко использует мотив космического путешествия;

3. литература, представляющая технические открытия, которым нет аналогов.

В качестве примеров такой фантастики писатель называет произведение Г. Уэллса «Первые люди на Луне»;

4. эсхатологическая фантастика. К такой фантастике Льюис относит «Машину Времени», «Когда спящий проснется» Г. Уэллса, «Конец детства» А. Кларка, «Первые и последние люди» Ол. Стейплдона [16, р.59-67].

В тесной связи с эсхатологической фантастикой находится и фэнтези. Исходя из природы фантастического, В.Л. Гопман предлагает различать «высокую» и «низкую» фэнтези. К высокой фэнтези автор относит произведения, где представлены вымышленные миры. Особенность низкой фэнтези автор видит в связи сверхъестественного с реальной жизнью.

В рамках фэнтези в зависимости от тематики произведения предлагается различать героическую, готическую, христианскую и оккультную фэнтези. Некоторые критики проводят различие между «эпической» и «героической» фэнтези. Произведения Дж. Р.Р. Толкиена, У.Ле Гуин, А. Нортон и Р. Желязны относят к «героической» фэнтези; произведения М. Пика и С. Кинга - к «готической» фэнтези, а Дж. Макдональда, Ч. Кингсли, Г.К.Честертона, Ч. Уильямса, К.С. Льюиса к «христианской» фэнтези.

Мы не разделяем мнения о принадлежности произведений Ч. Уильямса - романов «Война в небесах», «Старшие арканы», «Канун дня всех святых» к христианской фэнтези. При христианской основе в них много магии, оккультизма («Старшие арканы», например), а это противоречит христианскому мироощущению. Элементы магии присутствуют и у Льюиса, но они не имеет ничего общего с оккультизмом. Такие элементы определяют сказочное начало произведения. В III-ей части «Космической трилогии»- романе «Мерзейшая мощь»- мы вслед за Льюисом видим черты «духовного триллера». Высказывались и иные мнения относительно жанра романа Льюиса. К. Мэнлав (Colin Manlove) относит романы Чарлза Уильямса «Канун дня всех святых», «Война в Небесах» к детективному жанру [17, p.22].

Для становления фэнтези как жанра важно отметить роль героической фэнтези, фэнтези «мистического боевика», родоначальником которого были Р. Говард и Ф. Лейбер. Героическое фэнтези отличает преобладание 
действия над историей, незначительное присутствие мифологии («вторичного мира»).

По словам Кейси Фредерикса (Casey Frederiks), «в произведениях героической фэнтези миры, характеры и события являются своего рода гипотетическим контрастом реально существующему миру, где живут фантастические герои, а их поступки осознанны» [18, p.40].

К настоящему времени сложились три направления литературы фэнтези: «классическая» фэнтези (действие происходит в неком условном мифическом прошлом нашего или параллельного мира), «историческая фэнтези» (действие разворачивается на фоне реально развивающейся истории народов нашей Земли) и научная фэнтези (science fantasy), вносящая в традиционные сюжеты научной фантастики элементы сказочно-мифологического видения мира.

Жанровые особенности фэнтези важны для нас, поскольку они проявляются во многих произведениях Льюиса.

В литературе, посвященной научной фантастике и фэнтези, можно наблюдать смешение этих жанровых форм. Ричард Мэтьюз разграничивает два жанра, хотя не проводит резкой грани между фэнтези и готическим романом: «Фэнтези близко соприкасается с другими разновидностями реалистического романа, включая готические романы-ужасы, научную фантастику, утопические и сатирические произведения, и единственный путь выяснить принадлежность художественного произведения к фэнтези - это рассмотреть его во взаимосвязи с вышеперечисленными жанрами» [19, p.83].

Особенность научной фантастики мы видим в том, что: 1) мир фантастики строится по определенной модели, этот мир представлен как мир вероятный, соответствующий определенной научной модели; 2) для этого мира важны те же проблемы, что и для нашего мира.

Особенность фэнтези мы, вслед за Толкиеном, видим в следующем: 1) здесь представлен «вторичный» мир, схожий с миром первичным, но живущий по своим законам, часто иррациональным; 2) этот мир может помещаться в легендарном или мифологическом прошлом мире «первичного» или соседствовать с ним в настоящем: быть альтернативным вариантом, вариацией Земли» [20, p.14]; 3) фэнтези широко использует и преобразует миф.

Что же касается жанра научной фантастики, то, по мнению Р. Мэтьюза, «научно-фантастическое произведение изображает события в разумной Вселенной, которые могут быть объяснены с научной точки зрения, хотя на первый взгляд они могут показаться чуждыми и выдуманными» [21,там же, p.281.].

Г. Кирк (G.S. Kirk) отмечает связь фэнтези с мифом: «В мифе использу- 
ется воображение особого рода. Я назвал это фэнтези». Другой зарубежный критик - К. Фредерикс (Casey Frederiks) отмечает такие особенности фэнтези: 1) наличие мифологических героев, а также монстров, великанов, животных, обладающих сверхъестественной силой; 2) наличие немотивированных превращений. Как отличительную особенность фантастики автор отмечает важную роль темы научно-технического прогресса [22, p.40].

T. Маршал (Marshall В. Tym), К. Загорски (Kenneth Zahorski) и Р. Бойер (Robert H. Boyer) в своей книге «Literature: a core collection and Reference guide» используют термин «научное фэнтези» и дают такое ему определение. «Научное фэнтези - это тип высокого фэнтези, которое предполагает научное объяснение для существования вторичного мира и для портала, при помощи которого можно пройти из первичного мира во вторичный мир. В научном фэнтези основное внимание сфокусировано на магическом вторичном мире. В большинстве, но не во всех случаях наука и первичный мир отходят на второй план» [23, p.110].

В мировой литературе можно отметить немало произведений, представляющих синтез жанров, когда наряду с определенной жанровой доминантой можно увидеть признаки и другого жанра. К таким произведениям можно отнести и «Космическую трилогию» К.С. Льюиса.

Многие критики связывают фэнтези с литературной сказкой. И сам Льюис считал третью часть трилогии сказкой, так же он определял и жанр своих «Хроник Нарнии» [24, Т4, с.393-407]. Связь фэнтези и сказки отмечают и сами писатели. Известный писатель Ник Перумов на вопрос о природе фэнтези ответил так: «Фэнтези - нелепая калька с английского термина, у нас не оказалось своего русского термина для романа, повествующего о другой реальности, построенной на принципах объективного идеализма ..., где автор ничем не скован, кроме поставленных им самим условий. Литературная сказка - «литературный эпический жанр в прозе или стихах, опирающийся на традицию фольклорной сказки.... Чудесное как в народной, так и в литературной сказке не самоцель, не способ удивить читателя, а средство создания идеального сказочного мира, где побеждает благородство, доброта, бескорыстие. Чудесное в фантастике становится самоцелью, оно возникает в момент сомнения - сомнения как читателя, так и героя» [25, с.21].

М. Кравцова отмечает следующие различия фэнтези и сказки:

1) авторство произведения: если сказка может быть народной и не иметь автора, то фэнтези - всегда произведение авторское;

2) характер пространства: если в сказке пространство всегда условное, то в фэнтези это конкретное пространство, «освоенная» территория;

3) «историчность» произведения: в фэнтези история непосредственно разворачивается перед читателем;

4) фэнтези чаще реализуется романной структурой: это развернутый 
во времени сюжет [26, с.117-123].

Общность двух жанров М. Кравцова видит в наличии таинственного, чудесного, свехъестественного.

На близость фэнтези к сказке обращает внимание и писатель-фантаст С. Лем: «Принципы сказки, мифа, фэнтези и научной фантастики одинаковы и в том, что мир, который они конструируют, имеет общий знаменатель - однородность как гомогенность фундаментальной гармонии» [27, c.143].

Отметим то, что сближает фэнтези и фантастику:

1.И в том, и в другом жанре сюжет произведения построен на оппозиции добра и зла. Добро и зло в произведении персонифицированы.

2.Принцип двоемирия, проявляющийся в противопоставлении реальной действительности и фэнтезийного мира.

3.Фэнтэзийный мир обретает черты реального: это четко структурированный мир: язык, народы, география, карты (у Дж. Р.Р. Толкиена в эпопее «Властелин Колец», у Льюиса «Хроники Нарнии»; у Ле Гуин в цикле «Земноморье»). Этого нет в рациональной фантастике, где читатель «угадывает» черты реального мира.

4.В произведениях фэнтези непременно присутствует волшебство, магия, которая добывается героями либо путем изучения особых искусств, либо в качестве природного дара. Что касается превращений, еще Овидий в «Метаморфозах» направил в русло фантастики исконно мифологические сюжеты превращений (людей в животных, созвездия, камни) и положил начало фантастико-символической аллегории (пример которой мы наблюдали в притче «Расторжение Брака», и с которой мы сталкиваемся в «Космической трилогии» и в «Хрониках Нарнии»).

Фантастику же отличает следующее:

1)Поэтика фантастического связана «с удвоением мира, художник или моделирует собственный мир, существующий по своим законам или ... параллельно воссоздает два потока - действительного и сверхъестественного, иррационального бытия. В роли мистических, иррациональных мотивов выступают потусторонние силы, которые вмешиваются в судьбу персонажа, влияют на его судьбу» [28, столб.1120].

В вымышленном мире фэнтези обобщен мистический, символический опыт жизни в реальной вселенной; вымышленный мир, построенный на основе традиционной мифологии, порождает свою мифологию. Герой проходит испытания, связанные с нравственным выбором, и в зависимости от того, каков будет этот выбор, определяется будущее не только самого героя, но и той среды, из которой он вышел, а по большей части, всего мира.

2)Путешествие, которое совершает герой, - это путешествие в пространстве - со всевозможными невероятными приключениями («Одиссея», «Илиада» Гомера; ирландские и исландские саги и др.) 
3)Хронотопы фэнтези и фантастики отличаются друг от друга. В «фантастических произведениях пространственно-временные связи не вполне конкретизированы, условны; наблюдается неравномерный ход сюжетного времени, его задержки в точках описания, отступления вспять, параллельное течение в разных сюжетных линиях» [29, там же,стлб.1174]. Что касается фэнтези, то «миры фэнтези обычно лишены географической и временной конкретности - события происходят в условной реальности, чаще всего - в параллельном мире, похожем на наш» [30,там же, стлб.1161]. Для фэнтези важен и романтический принцип двоемирия, противопоставления мечты и реальности [там же].

4)Восприятие произведений фэнтези создается эффектом эмоционального соприсутствия читателя с героями произведения, той культурной средой и традицией (в том числе и духовной), которую писатель преподносит читателю.

5)Что касается фантастических произведений, то, по выражению Кира Булычева, «фантастика - не только художественная литература, но и пища для развития воображения, для творчества, стимул для поиска альтернативы, прогресса» .... Она стимулирует желание человека двигать научнотехнический прогресс, «исследовать жизнь социума и индивидуума, происходящие в них изменения под действием сдвигов в развитии науки и техники» [31(12), с.46]. По замечанию Э. Араб-Оглы, по своему социальному назначению научная фантастика призвана в художественной форме «...осмыслить будущее человечества и цивилизации. Недаром она получила общепринятое и само по себе достаточно выразительное наименование: литература предвосхищения» (la literature d'anticipation), «перенесения будущего в настоящее» [32, с.109.]. Многие критики и публицисты отмечают тот факт, что прогнозированные писателями-фантастами будущие прорывы в технике уже нашли свое воплощение в реальном мире.

Проблема фантастического мира интересовала Льюиса в свете устройства мироздания, межпланетных путешествий, путешествия в иные миры. Об этом Льюис писал в литературно-критических эссе «Аллегория Любви», «Отброшенный образ» (1964) и других статьях и эссе. В автобиографии «Настигнут Радостью» (1955) Льюис отмечает, что на него большое влияние оказали Райдер Хаггард и научная фантастика Уэллса: «Иные миры пробуждали во мне какой-то умозрительный интерес, совершенно отличавшийся от моего отношения к другим книгам. Это ни в коем случае не было романтикой неведомой дали... Написанные мной инопланетные приключения - не попытка удовлетворить подростковую тягу, я скорее пытался изгнать беса или подчинить его более высокой и чистой фантазии» [33,T.7. c.287].

В работе «Отброшенный образ» Льюис пишет: «Если бы астронома 
спросили 50 лет назад о жизни в других звездных системах, то он бы посчитал этот вопрос нелепым, а саму идею неправдоподобной. Нам много раз говорили, что звезды окружены планетами, планеты населены, но нет реальных этому доказательств. И все же возможно предположить, что прежнее мнение и настоящее - повод к научно-фантастическим идеям, а путешествие в космосе - реально? Надеюсь, никто не подумает, что я призываю возвратиться к средневековой модели вселенной.... Что касается Новой Модели, то она не будет принята без доказательств, поскольку у природы есть множество доказательств; стоит только внимательней к ней присмотреться - ответ будет получен» [34, р.222-223].

К проблеме фантастического Льюис обращается в эссе «On stories» («Об историях»). Он обращает внимание на произведения Д. Линдсея «Путешествие к Арктуру», подчеркивая оригинальность и духовное содержание романа: «Главной составляющей всех историй о космических путешествиях и других мирах является не столько необычность как физических, так и пространственных параметров, сколько идея о другом измерении. Для того, чтобы создать правдоподобные и живые «другие миры», следует лишь изобразить другой мир, который вы знаете - мир Духа» [35, p.11-15].

Не меньший интерес у Льюиса вызывал роман Джонатана Свифта «Путешествие Гулливера» где главный герой попадает в разные фантастические страны, а также романы Ж. Верна, О. Стейплдона «Первые и последние люди», («Last and First Men»), А. Кларка «Конец детства» («Childhood End»), Дж. Денниса «Конец мира» («The End of the World»), Дж. Халдейна «Возможные миры» (1927) («Possible Worlds») и другие. По мнению К.С. Льюиса, произведения такого рода дают пищу для размышления. Он подчеркивал роль журнала, издаваемого в Америке, - «Фэнтези и Научная фантастика» (Fantasy and Science Fiction), где можно прочитать не только произведения о космических путешествиях, но и рассказы о богах, привидениях, демонах, монстрах и т.д. Льюис объясняет факт стремления человечества к другим звездным системам и планетам не тем, что оно заинтересовано поиском красоты или ужаса, которые современный мир не может предоставить, а интересом к жизни разных стран и континентов.

Фантастическое Льюис видит и у Данте в «Божественной Комедии», и приводит в качестве примера эпизод, когда Данте и Вергилий после того, как спустились с плеч до поясницы Люцифера, обнаружили, что им приходится взбираться с его поясницы до ног. По мнению Льюиса, это говорит о том, что Вергилий и Данте преодолели центр гравитации; само описание этого момента у Данте Льюис считает великолепным примером научной фантастики [36, с.63-65].

Мысли Льюиса о загадочной жизни других планет, о тяге к неизвестному нашли отражение в «Космической трилогии», где центральное место занимает духовный поиск - quest. Как отмечает А.В. Ващенко, понятие 
«quest» восходит еще к временам рыцарского романа. «Понятие «quest» включает в себя странствие, поиск и испытание». Поиск - это не только борьба с врагом, это, прежде всего «нравственный искус», встреча с самим собой. Поэтому герой «Космической трилогии» - человек, способный к духовному преображению.

От типичного произведения фантастики «Космическую трилогию» отличает то, что пафос произведения научной фантастики - пафос прогресса, тогда как для Льюиса главным остается человек и его нравственная сущность.

References:

[1] Derik Binham.Lewis C.S. The Story Teller / Wr By Derich Bingham, Christian Focus Publication, Ltd, Scotland, Great Britain (Клайв Льюис и его сказки. Деррик Бинхам, Пер. на русск. яз. // Библия для всех. - Спб., 2001.

[2] Wright, Majoric E. The Cosmic Kingdom of Myth: A study in the Myth Philosophy of Charles Williams, C.S. Lewis, and j. RR. Tolkien. University of Illinois, 1960.

[3] Walsh, Chad. The Literary Legacy of C.S. Lewis. Harcourt Brasce Jovanovich. N.Y. 1979.

[4] Gibb, Jocelyn. Light on C.S. Lewis. Geoffrey Bles: London: Contributors include Owen Barfield, A.W. Benneff, Nevill Coghill, Austin Farrer, Stella Gibbons, Walter Hooper and others. 1965.

[5] Sayer, George. Jack: C.S. Lewis and his times. Macmillan, 1988.

[6] Willian Roberts. The game of Impossible: A Rhetoric of Fantasy. - Illinois press. Cop.1976.

[7] Ковтун Е.Н. Поэтика необычаного - М., 1998.

[8] www.tolkienlewis.narod.ru. С. Кошелев. К.С. Льюис и его Страна чудес.

[9] Льюис К.С. Собрание сочинений в восьми томах. М.,1988.

[10] Литературный энциклопедический словарь. / Под ред. В.М. Кожевникова и П.А. Николаева. - М., 1987.

[11] Брандис Е. Научная фантастика и человек в сегодняшнем мире // Вопросы литературы. 1997.-№6.

[12] Чернышова Т. Природа фантастики. - Иркутск, 1984.

[13] Тодоров, Цветан. Введение в фантастическую литературу / Пер. с фр. Наумова Б. - М., 1999

[14] Чернышова Т. Природа фантастики. - Иркутск, 1984.

[15] Ковтун Е.Н. Истинная реальность фэнтези (fantasy) // Вестник Московского Университета. 1998.

[16] Lewis C.S. On Stories. London: Collin, 1982.

[17] The new encyclopedia of science fiction Ed. by Games Gunn. - N.Y., 1980.

[18] Manlove C.H. Modern fantasy. Five studies. Cambridge., 1975.

[19] там же.

[20] Mathews, Richards. Fantasy: the liberation of imagination. - N.Y.,1997

[21] там же.

[22] Casy Frederics. The Future of Eternity.Indian University Press. 1982. 
[23] Tymn M.B., Kenneth., Zagorski and Robert H.Boyer. Fantasy literature: a core collection and reference guide//RR.Bowker company. - N.Y.,Canada. 1979.

[24] Льюис К.С. Страдание // пер. С англ. Н.Л.Трауберг. - М., 1990.

[25] Ващенко А.В. Суд Париса: Сравнительная мифология в культуре и цивилизации. - М.,2008.

[26] Кравцова М. Чтобы сказка не кончалась. - М., 2004.

[27] Лем С. Фантастика и футурология в 2 кн. / Пер. с польского С.Н. Макарцева. М., 2004.

[28] Литературная энциклопедия терминов и понятий. / Под ред. А.Н. Николюкина. - М., 2003.

[29] Там же, столб.1174

[30] Там же, столб.1161

[31] Чернышова Т. Природа фантастики. - Иркутск, 1984.

[32] Араб-Оглы Э.Л. Книга Кингли Эмис Новая пародия ада // Вопросы философии.1962- №10.

[33] Льюис К.С. Собрание сочинений в восьми томах. М.,1988.

[34] Lewis C.S. The Discarded image. An introduction to Medieval and Renaissance Literature. Cambridge University Press: Cambridge, 1964.

[35] Lewis C.S. On Stories. London: Collin, 1982.

[36] Lewis C.S. Perelandra. John Lane: London, 1943. Reprinted in paper back as "Voyage to Venus". Pan Books: London, 1953.

[37] Ващенко А.В. Суд Париса: Сравнительная мифология в культуре и цивилизации. - М.,2008. 


\title{
HISTORICAL SCIENCES
}

\author{
MISSIONARY HISTORICAL-ETHNOGRAPHIC MUSEUM \\ OF THE KAZAN THEOLOGICAL ACADEMY (1912-1919): CONTRIBUTION \\ TO THE PRESERVATION OF HISTORICAL AND CULTURAL HERITAGE \\ OF THE PEOPLES OF THE VOLGA REGION, URALS AND SIBERIA
}

\section{Khabibullin ${ }^{1}$}

\begin{abstract}
The experience of creating and functioning of Russia only Missionary historical-ethnographic museum. On the basis of archival materials the author reveals the peculiarities of the activities of the museum in the Kazan spiritual academy. Determined the contribution of the museum in preservation of historical and cultural heritage of the peoples of Russia.
\end{abstract}

Keywords: Missionary historical-ethnographic museum, Kazan theological Academy, the missionary policy, the collection, the history, the culture, peoples of Russia.

В 1842 г. была открыта известная на всю Россию Казанская духовная академия. Фактически до момента закрытия в 1920 г., она являлась крупным научным, духовным и образовательным центром по изучению языков, истории, этнографии, культуры финно-угорских, тюркских и монголоязычных народов центральной и восточной частей России. Ее история неразрывным образом связана с миссионерской политикой, которая активно осуществлялась по отношению к нерусским народам Российского государства. Поставленные перед академией цели и задачи, а также специфика данного учреждения требовали привлечения в ее стены талантливых преподавателей, интересующихся историей и этнографией нерусских народов России. Руководство Казанской духовной академии стремилось связать просветительскую политику государства с активным изучением объекта своего исследования. Так, именно с этой целью, в ее стенах в 1854 г. были открыты 4 миссионерских отделения: противораскольническое, противомусульманское, противобуддистское и черемисско-чувашское. История отделений отражена в публикациях современных авторов [7]. Они, собственно говоря, и стали центрами по изучению народов Поволжья, Приуралья и Сибири.

В результате многочисленных командировок преподавателями отделений Казанской духовной академии было накоплено большое количество

${ }^{1}$ Mars Khabibullin, Candidate of historical sciences, associate Professor, scientific Secretary of the Institute of Tatar encyclopedia and area studies Academy of Sciences of the Republic of Tatarstan, Tatarstan, Russia. 
документальных источников, научных отчетов, книг и других предметов, отражающих культуру, быт, обычаи, национальные праздники многих народов России. Большинство этих ценных вещей были собраны в миссионерском историко-этнографическом музее (МИЭМ) Казанской духовной академии, который был организован в 1912 г. при фундаментальной библиотеке академии. А официально музей был открыт в 1913 г. в соответствии с указом Св. Синода от 9 января 1913 г. [3].

Основными задачами миссионерского историко-этнографического музея были изучение, приумножение и использование исторических, культурных, научных ценностей и материалов, касающихся истории и этнографии народов Российской империи, популяризация этнографических знаний, научное исследование в области материальной культуры, духовной жизни, традиций, истории народов. Материалы из фондов музея использовались в учебно-образовательной и исследовательской деятельности студентов, преподавателей и научной деятельности миссионерского отделения академии.

Большое значение для комплектования фондов имели пожертвования, преподавателей академии. Многие обладали многолетним опытом миссионерской деятельности. Так, доцент академии по кафедре калмыцкого языка архиепископ Иннокентий (Илья Иванович Ястребов, 1867-1928) в течение 14-летней миссионерской деятельности несколько раз побывал в калмыцких улусах Астраханской губернии для изучения языка, быта и религиозных верований калмыцкого народа, путешествовал в Сибирь, совершенствуя опыт в миссионерской деятельности и изучая язык сибирских монголов [6]. Ученым-востоковедом профессором академии по кафедре миссионерских предметов архиепископом Суздальским Гурием (Алексей Иванович Степанов; 1880-1938) были пожертвованы ценные коллекции буддийских, монгольских, калмыцких и бурятских идолов и других предметов домашнего быта этих народов [2].

Богатую коллекцию из более ста предметов, привезенных из Монголии, в дар музею преподнес специалист по ламаизму иеромонах Амфилохий (Скворцов Александр Яковлевич, 1885-1937; впоследствии епископ Енисейский и Красноярский). В числе предметов были изображения буддистских богов и богинь на полотне, из терракоты, бронзы, дерева и папьемаше, ксилографические доски для печатания молитв, принадлежности шаманского культа, четки, китайские монеты и многое другое $[4,5]$. По возвращении в 1914 г. из двухлетней командировки в Монголию, помимо научной и преподавательской деятельности, он принимал самое активное участие в судьбе музея, будучи помощником директора [1].

Еще один источник формирования музейного собрания - это научные экспедиции выпускников академии. С 1842 г. Казанская академия активно осуществляла собирательскую деятельность, в которой участвовали студенты. В то же время при создании музея значительный вклад в комплектование его фонда внесли выпускники академии, что объяснялось родом их деятельности. Выпускников академии направляли в качестве миссионеров в разные, а порой в самые отдаленные районы Российской империи. 
Проповедуя православие среди нерусских народов, они соприкасались с их жизнью и бытом, знакомились с историей, обычаями, традициями, отраженными в памятниках материальной культуры и письменных источниках, которые собирались и передавались затем в академический музей. К письменным источникам относились путевые и прочие заметки, письма, дневники и очерки, в которых фиксировались обычаи, знания и навыки, язык, устный эпос, музыка, танец, игры, мифология, ритуалы, ремесла, традиционные формы коммуникации, знаки и символы и т.п.

Благодаря таким записям о разнообразной жизни отдельного народа создавался фонд нематериального культурного наследия, представлявший совокупность традиционных форм культурной деятельности и представлений народа. Указанный фонд мог оказывать неоценимую помощь в учебном процессе. К сожалению, эта задача не была реализована в связи с непродолжительным функционированием музея.

В период функционирования Казанской духовной академии (18421920) активно формировался ее музейный комплекс, который стал неотъемлемой частью учебного заведения, структурным звеном, культурнопросветительским центром академии. Его доминирующей частью стал миссионерский историко-этнографический музей, созданный при библиотеке на базе учебных коллекций. Собрание музея формировалось как совокупность коллекций, которые отражали культуру многонационального населения Российской империи. Оно давало представление о конфессионально-этническом многообразии народов, существовавшем к концу XIX столетия. В коллекциях музея содержится много интересных сведений по истории и этнографии народов Поволжья, Приуралья и Сибири, Восточной Азии, представляющих большой интерес для современных исследователей.

\section{References:}

[1] Дамаскин (Орловский), иеромонах. Мученики, исповедники и подвижники благочестия РПЦ XX столетия: Жизнеописания и материалы к ним. Кн. 6. Тверь, 2002. $479 \mathrm{c}$.

[2] НА РТ. Ф. 10. Оп. 1. Д. 11358.

[3] НА РТ. Ф. 10. Оп. 1. Д. 11571.

[4] Отчет о состоянии Казанской Духовной Академии за 1909-1913 гг. Казань, 1913.

[5] Протоколы заседаний Совета КазДА за 1907-1913 гг. Казань, 1913.

[6] Протоколы заседаний Совета Казанской духовной академии за 1890 г. Казань, 1891.

[7] Хабибуллин М.З., Шайдуллин Р.В. Деятельность миссионерских отделений в Казанской духовной академии (вторая половина XIX - начало XXвв.) // Вестник Екатерининского института. М., 2014. № 4 (28). С. 141-144; Хабибуллин М.З., Вагазова Р.М. Общественная и педагогическая деятельность Василия Тимофеевича Тимофеева (1836-1895 гг.) // «Наука и бизнес: пути развития». Москва, 2012, № 6 (12). C. 41-44. 


\section{HISTORY OF PHYSICAL CULTURE AND SPORTS IN THE SIMBIRSK PROVINCE IN 1852-1939 (THEORETICAL REVIEW)}

\section{Nazmutdinova ${ }^{1}$, G. Nazmutdinova ${ }^{2}$}

\section{Abstract}

The article is devoted to the history of physical culture and sports in the Simbirsk province in the period of the second half of the XIX century. The article gives a detailed analysis of the leisure of citizens of Simbirsk, the history of sports societies, the establishment of sports competitions in the period of the XIX - early $\mathrm{XX}$ centuries, the development of the physical culture in the period of establishment of the Soviet power Simbirsk. Social and economic development of the region and formation of physical culture in the region are Interconnected

Keywords: physical culture, sport history, leisure, Simbirsk, 19th century, 20th century.

Досуг и праздники горожан Симбирска конца XIX- начала XX вв. большое значение имело общение; интеллектуальные игры - карты, шахматы; постоянное посещение театра; пешие прогулки по городу, зимой - катание на лыжах и коньках; любительские концерты; посещение выставок и музеев; у мужчин - охоту и рыбалку; чтение, покупку книг, пользование библиотекой, обмен книгами с друзьями; эстетическое воспитание детей; домашний театр и семейное музицирование на фортепьяно, гитаре, народных инструментах [1]. Главными спортивными увлечениями были охота на диких животных, состязания в воинской доблести, включающие скачки, стрельбу по мишеням, фехтование и другие подобные упражнения [6].

В начале XX века среди горожан Поволжья было немало любителей активного отдыха, поклонников разных видов спорта. Летом обыватели занимались греблей, футболом, велосипедным спортом. В первые дни первой мировой войны в костромской газете сообщалось: «В Кинешме и ее окрестностях процветает спорт и, главным образом, футбол. На Межаковом поле ежедневно происходят игры и не менее одного раза в неделю - публичные состязания различных футбольных команд». В Казани 25-26 сентября 1916 г. на озере Кабан местный яхт клуб организовал соревнования на первенство города в одиночной и парной гребле [15].

Зимой организовывались состязания лыжников, конькобежцев. В частности, в Казани на озере Кабан 29 ноября и 13 декабря 1915 г. прошли лыжные гонки, яхт-клубом был устроен конькобежный каток, на котором в

1Veronica Nazmutdinova, Candidate of Biology Science, the Tyumen State University, Russia.

${ }^{2}$ Gulnara Nazmutdinova, Teacher highest category of additional education, the Ulyanovsk State Technical University School, Russia. 
конце декабря 1916 г. в календарных состязаниях принимали участие гонщики трех разрядов. Катание на льду было распространенной формой зимнего досуга в разных городах Поволжья. Катки были как платными, так и бесплатными. Так, в Пошехонье зимой 1914-1915 гг. устраивали бесплатный каток, а в ноябре 1915 г. с посетителей стали брать плату. В Нижнем Новгороде действовал платный каток военно-спортивного комитета. В ноябре декабре 1916 г. его посетили 4503 нижегородца. У жителей Астрахани пользовался популярностью каток в порту. За зимний сезон 1916 г. на него было продано 1233 билета, в том числе 400 - по 20 коп., 728 - по 15 коп., 105 - по 10 коп. В Казани на катке яхтлуба 5 февраля 1917 г. прошел костюмированный карнавал - катании. Во время первой мировой войны, несмотря на рост цен, горожанин находил средства на приобретение билета, позволявшего провести свободное время так, как ему хотелось: посмотреть зрелище, послушать музыку, покататься на льду катка, пообщаться со знакомыми, испытать удачу в игре или просто погулять в непринужденной обстановке в комфортном для прогулок месте [15].

Праздники. В ходе Сабантуя проводились различные игры: национальная борьба, бега, танцы пешие гонки, гонки на лошадях. В мае 1891 г. на рамках Сабантуя в Казани были проведены конные скачки. Победители различных игр получали карманные часы, денежные награды и другие ценные призы. Праздник способствовал сохранению и дальнейшему развитию национальных традиций татар и других народов Поволжья и Приуралья. Роль татарских предпринимателей в организации и проведении Сабантуя на рубеже XIX-XX вв. сохранялась в жизни татарского общества и в первые годы советской власти [15].

Первое массовое общество в Симбирске - любителей конского бега - открылось в Симбирске в декабре 1852 г. благодаря усилию нескольких коннозаводчиков (П.Б. Бестужева, А.Л. Бычкова, Е.А. Беляковой, Н.М. Теренина и др.). 25 января общество уже устроило первые от имени общества в городе рысистые бега, о чем уже писали в местной газете. В заезде на 20 верст (11 кругов) участвовало десять троек лучших симбирских рысаков. Победителям достались призы: за 1-3 места серебряный колокольчик в 3 фунта и шелковый кушак ямщику, два серебряных бубенца и «крымская шапка» ямщику, кнут с серебряной оправой. Все призы были изготовлены симбирскими мастерами. Дворянин Н.М. Теренин на свои средства заказал каждому наезднику по массивному серебряному вызолоченному перстню с надписью «Первый бег в Симбирске 1853 года». На средства общества за городом (в районе нынешнего моторного завода) был устроен небольшой ипподром, где обычно в мае проходили спортивные бега в несколько этапов с денежными призами и раздачей дипломов. Просуществовало общество до Первой мировой войны [6].

«Лошадь столетия». У Дурасовых был конный завод рысистых пород. Старая Зиновьевка Карсунского уезда Симбирской губернии в глинобитных конюшнях размещались рабочие лошади и лошади башкирской породы, в основном, метисы, помесь баткарской и арденской пород, приобре- 
тенные в своё время в конюшне князя Вяземского. На скачках серый в яблоках жеребец Крепыш, приобретённый до Первой мировой войны Александрой Федоровной Дурасовой, стартовал 79 раз, из них 55 раз приходил первым к финишу, 13 раз улучшал предельные рекорды в гг. Москва, Санкт-Петербург и др. За всё время скачек им было выиграно более 300 тысяч рублей! [23].
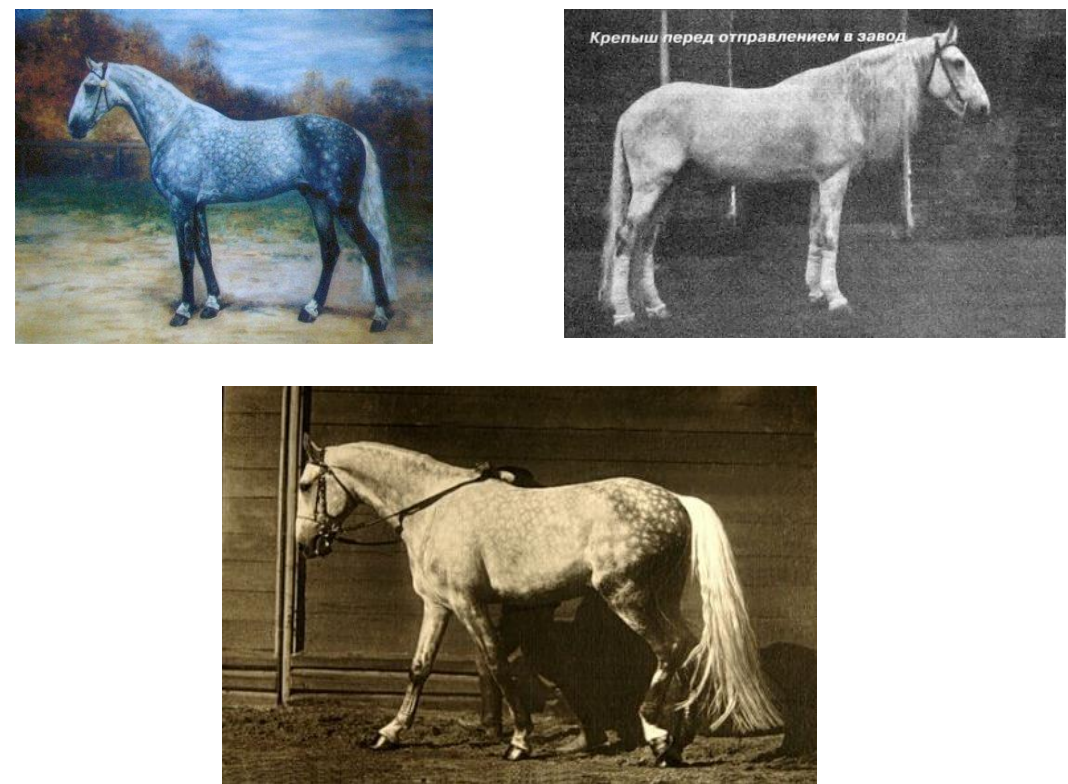

Рис. «Лошадь столетия»

Апанаевы, Абушаевы, Ишмуратов и другие татарские предприниматели Казани содержали конные заводы, где выращивались кони, в т.ч. беговые рысаки [16]. Конные скачки проводились в Казани, других городах Поволжья и Приуралья. В 80-90-х гг. XIX в. в Самарской губернии владелец Мулловской суконной фабрикой Хисаметдин Алеев, кроме угощения во время традиционных праздников для рабочих и служащих устраивал конные скачки, борьбу силачей и танцы. Большим любителем лошадей был казанский татарский промышленник и купец Я.С. Акчурин, фабрикант из татар Симбирской губернии, кони которого участвовали на крупных скачках Поволжья. Его жеребец серый Удалой 6 лет успешно принимал участие в бегах, организованных Симбирским обществом охотников конного бега в г. Симбирске [16]. В предвоенные годы появились автомобили. Некоторые конезаводчики, например, Николай Карлович фон Мекк увлекся автомобильным спортом и был призером многих автогонок [2].

В конце XIX- начале XX в. в Симбирской губернии стали открываться профессиональные, музыкально-драматические, спортивные общества. На протяжении многих столетий спорт был привилегией избранных, отож- 
дествлялся с развлечением и удовольствием, за которые надо было платить. «Симбирское губернское по делам об обществах присутствие» (19061917 гг.) занималось регистрацией вновь возникающих обществ на территории Симбирской губернии. За 1906-1917 гг. в Симбирске и губернии было открыто более 100 обществ, союзов, клубов, кружков: новые общества велосипедистов, кружок парусного и гребного спорта, фотографическое общество, общество эсперантистов и др. Почти все спортивные общества состояли из молодых людей [12].

В начале XX в. спорт с каждым годом начал завоевывать себе все больше и больше внимания среди жителей Симбирской губернии. Польза спорта была очевидна для каждого интеллигентного человека того времени [11]. В своих дневниках Л.Н. Толстой вспоминает: 14 марта 1907 г.: Иосиф Константинович (о Чертковых): Владимир Григорьевич очень занят своей работой - «Сводом мыслей». Л.Н.: лекциями, футболом... страстно предан спорту, к России вряд ли привыкнет ... Соседи-земледельцы возмущаются постоянной игрой господ в футбол. Играют даже при фонарях. Л.Н.: Футбол, лаун-теннис, лодки возможны только при рабстве. И.К. рассказывал о Фельтене, что он подвижной спортсмен ... В Шотландии становится меньше земли, потому что одна пятая отведена под спорт [8]. 16 сентября 1910 г.: Л.Н. спросил, взглянув на портреты: Кто это? - Авиаторы. - Бедные! Как они бьются. Это спорт. Я понимаю, что молодому человеку лестно показать свою смелость (мужество). 15 июля 1910 г.: Л.Н.: в молодости своей сам был большим любителем гимнастики [9].

Образованные молодые люди хотели внести в провинциальную жизнь Симбирска новомодные виды спорта: парусного и гребного. В 1906 году в г. Симбирске открылся кружок парусного и гребного спорта. Его учредителями стали люди далеко не бедные, которым и моторная лодка, и яхта были по карману. Входили в кружок симбирские предприниматели, страховые агенты, чиновники высших рангов. Например, сын директора народных училищ Симбирской губернии, В.П. Мартынов - коллежский советник, доктор медицины И.А. Стрелков [11]. Со временем кружковцы выстроили на волжском склоне недалеко от своего причала яхт-клуб. Час катания на шлюпке стоил 25 копеек для всех желающих. Кружок парусного и гребного спорта существовал на членские взносы и средства, заработанные от спектаклей и вечеров [6]. Целью общества было также улучшение постройки судов и изучение речного дела. Для этого кружок устраивал гонки судов, назначал маневры, строил и покупал по силе суда и модели. Кроме этого члены кружка проводили разного рода гимнастические упражнения, игры, плаванья, катанья на коньках, фехтования, беги на лыжах [11]. 

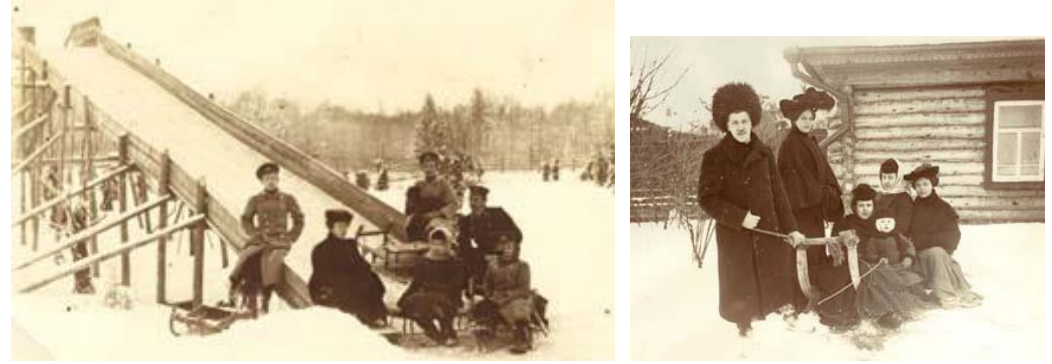

г. Симбирск. Зимой пешие прогулки заменяли катанием на коньках на катках и реках, а так же катанием с гор на санках, тем более что оврагов и гор в городе было предостаточно. Это были забавы не только детворы, но и молодежи. Никаких ограничений у входа на каток не было [6].

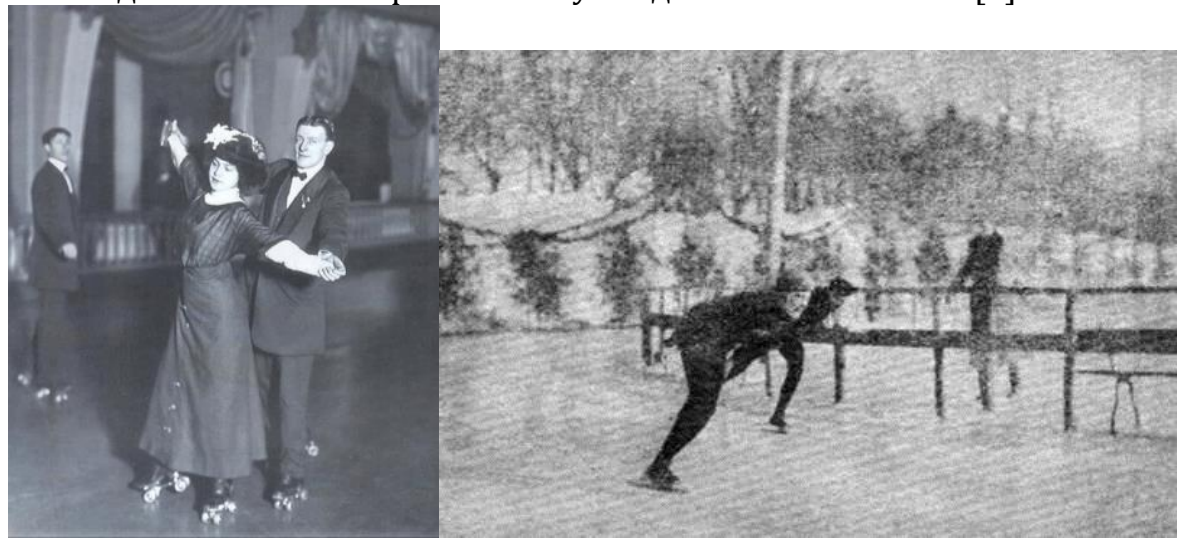

Катание на роликовых коньках, 1910-е годы. Фото со скетингринга. г. Самара [22]
1916 г, Казань, «Черное озеро». Забег конькобежцев [20] 

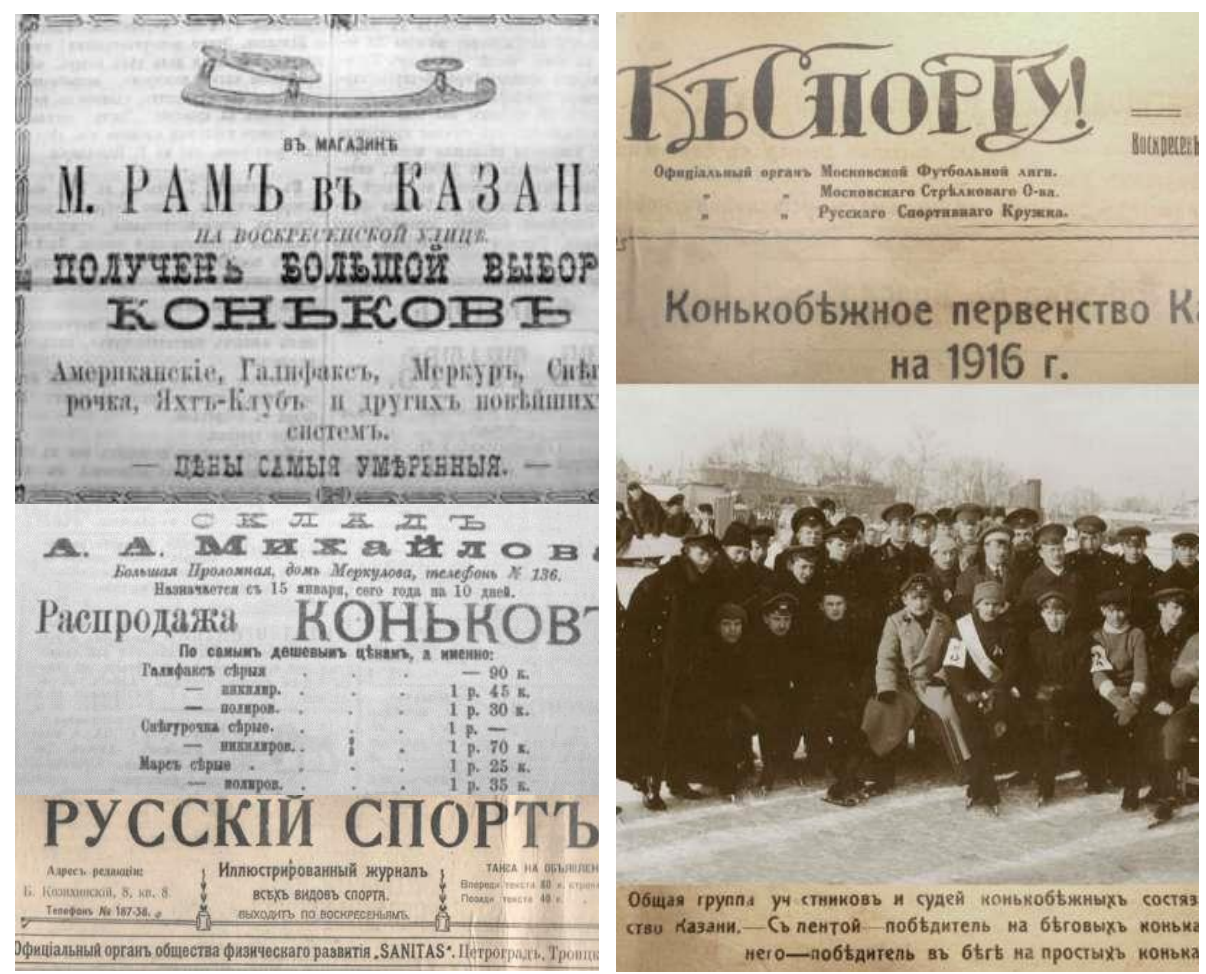

Казань. Магазины торговали коньками разных видов. Объявления об этом печатались в казанских газетах. В январских номерах 1902 г. газета «Казанский телеграф» опубликовала следующие объявления. Источник: Зарождение конькобежного спорта в Казани 1900-1917 гг. [20].

В 1915 году кружковцы откликнулись на призыв спортивной общественности города и открыли у себя отделение для занятий более дешевыми и популярными у молодежи видами спорта - футтболом и легкой атлетикой. В мае того же года, как пишет краевед Ю.Д. Ефимов (Краеведческие записки, вып.10), в Симбирске на единственной в городе спортивной площадке и футбольном поле на Александровской площади (у здания городской электростанции) состоялся самый интересный футбольный матч тех лет между «Первой железнодорожной командой» из Самары и «Симбирским яхт-клубовским кружком»: «...Входной билет стоил 10 копеек, билет на право сидеть на скамейке - 50 копеек... Посмотреть игру лучшей команды в Поволжье собралось более трех тысяч зрителей ... Симбиряне впервые увидели футбольную форму. Самарцы были одеты в оранжевые футболки и «специальные ботинки».

Футбол в те годы был самым популярным и массовым видом спорта у горожан. Почти во всех районах города стихийно создавались свои уличные футбольные команды. Организовывались они и в учебных учреждениях, воинских казармах, среди интеллигентов и чиновников. Существовали ко- 
манды очень недолго, распадались из-за недостатка средств. В 1916 г. с десяток команд, такие, как «Спарта», «Реальное», «Венец», «Виктория» и др., приняли участие в первенстве Симбирска по футболу [6].

Велосипед стал модным развлечением. Симбирское общество велоcuneдистов (1894-1896 гг.). Его организовали купец А.К. Юргенс и инженер М.И. Махчинский. Устав общества был утвержден министром внутренних дел 28 августа 1894 г. К северу от города, в районе Ленкоранских казарм, ныне район училища связи, кружком был арендован небольшой клочок земли, организован велотрек. За умеренную плату все желающие могли обучаться велосипедной езде. С 1894 по 1896 г. общество организовало семь велогонок на стадионе и одну на сто верст за его пределами. В 1908 г. подобное общество появилось в другом крупном уездном городе Сызрани. Инициатором его создания был саратовец Н.И. Пашков. 16 февраля 1909 г.
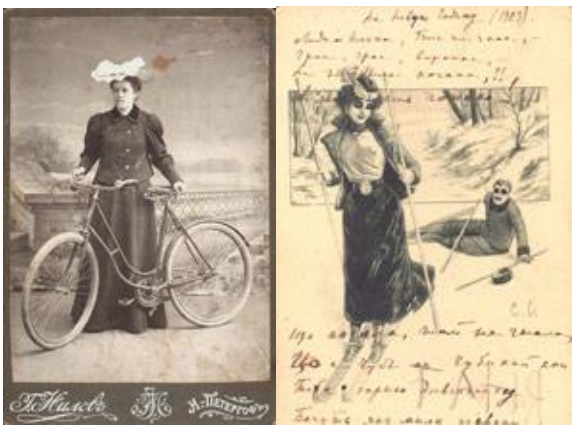

Знаменитый борец Иван Заикин. г.р. - 5 ноября 1880 года, с. Верхнее Талызино Симбирской губернии [24]

Фотографии и открытки из коллекции А. Сытина (нач. XX в.) [6]

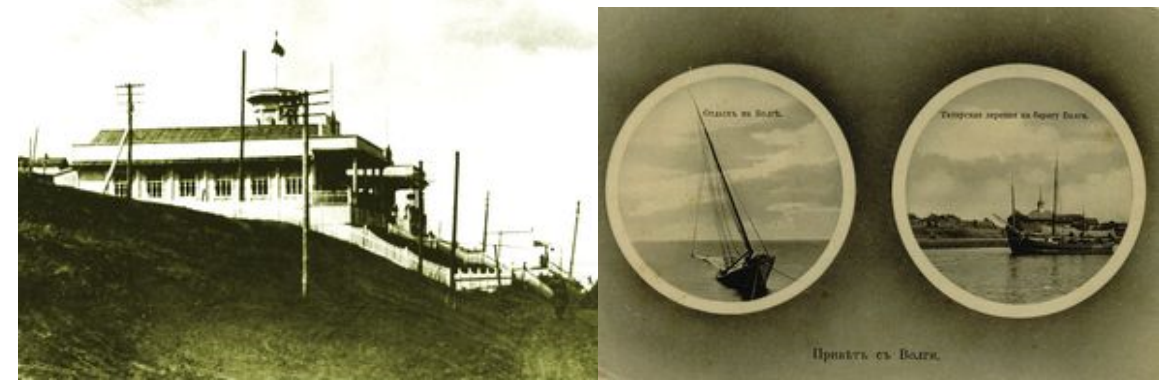

Симбирский яхт-клуб. Фото 1920-х годов [5] 


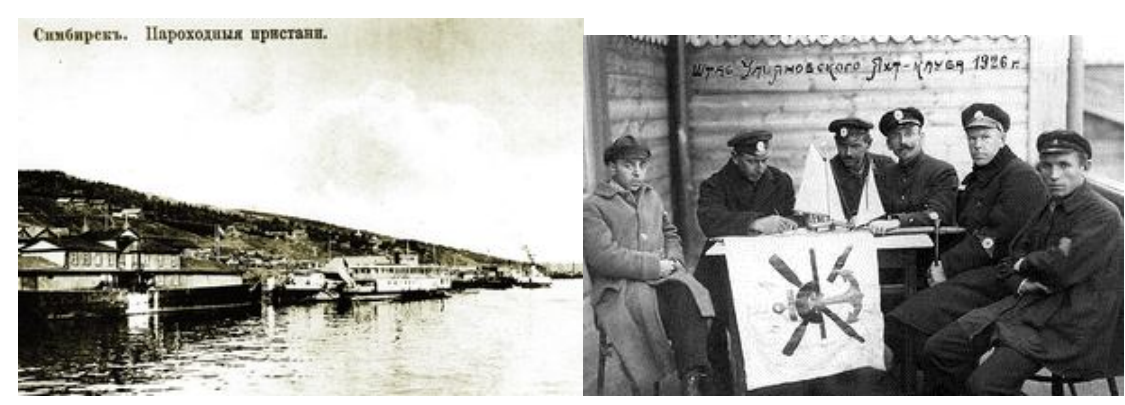

Симбирская пристань и дачная местность

Яхт-клуб. Ульяновск. 17 октября 1926 г. (из книги «Русская семья в во«Колки» на дальнем плане. Фото 1910-х гг. [5].

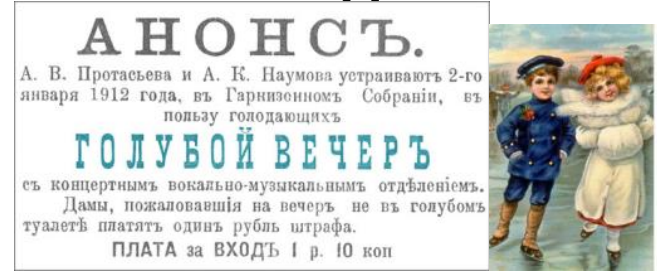
довороте «Великого перелома». С-Пб, 2005) [5].

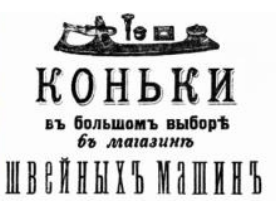

М. В. Мякиньковой,

Губернское по делам об обществах присутствие постановило внести в реестр обществ по Симбирской губернии $[6,11]$. Помимо велосипедных гонок, там можно было увидеть веселые спектакли, послушать музыку, покататься на «колесных» (роликовых) коньках, поупражняться в фехтовании, а также поиграть в шахматы, шашки, кегли и сразиться на бильярде. Но и это общество закрылось в 1915 году [6].

С давних пор в зимнее время у симбирян были очень популярны коньки u лыжи. Любители кататься на коньках своими силами устраивали катки на р. Свияге, Маришке, других мало-мальски подходящих замерзающих водоемах города. Но официально в Симбирске существовал единственный каток, впервые устроенный в Николаевском саду (ныне сквер у памятника К. Марксу) зимой 1903 г. семейно-педагогическим кружком для детских игр. Городская Дума ежегодно выделяла небольшие средства для его заливки и содержания. В праздничные дни катания на нем проходили под оркестровую музыку при яркой иллюминации. В январе 1915 г. и феврале 1916 г. там даже прошли общегородские соревнования по бегу на коньках на 500 и 3000 м на первенство Симбирска [6].

Несмотря на начавшуюся мировую войну, устраивались в те годы и лыжные соревнования, о чем пишут в своих исследованиях краеведы Ю.Д. Ефимов и И.Э. Сивопляс. Так, 27 декабря 1914 г. у Минаевского кладбища (находилось в районе Речного порта) прошла лыжная гонка на 3 версты по пересеченной местности, а 6 января 1915 г. в Киндяковке имело место состязание по прыжкам на лыжах с трамплина. 15 февраля того же года состоялись лыжные гонки на 4 версты на первенство Симбирска. 
Участвовали симбирские спортсмены в лыжных гонках из Симбирска в Казань и Самару. В 1915 г. в пробеге Симбирск-Самара приняли участие 15 лыжников - рекордно большое для военного времени число. Для поощрения лыжного спорта в 1916 г. отдел физического развития Городской управы устроил в городе на Покровской улице (ул. Л. Толстого) лыжную базу, где лыжи выдавались напрокат [6].

Наиболее основательно официальные соревнования по скоростному бегу на коньках были проведены в 1916 г. Об этих соревнованиях достаточно обстоятельные отчёты были опубликованы в московской газете «К спорту» и петербургском журнале «Русский спорт» [20]. 28 февраля 1916 г. в газете «Русский спорт» сообщалось: для участия конькобежном первенстве Поволжья откликнулись на призыв Казани пять крупных городов: Самара, Саратов, Симбирск, Нижний Новгород и Ярославль. К старту явились: Г.И. Голубчиков (Саратов), г-да Ситовский и Петров (Самара), В.Н. Сивинцев (Симбирск), г-да Морковкин, Ананьев, Крюгер, Федоров, Хворов (Казань). Пашин (Нижний Новгород). Симбирск в лице В.Н. Сивинцева занял третье место, также с вполне приличными результатами. Сивинцев (Симбирск): 500 м - 56,0 сек; 1500 м - 2 мин 59,0 сек; 5000 м - 10 мин 44,4 сек3 место [20].

Постепенно соревнования в беге на лыжах становятся традиционными и более массовыми в связи с популярностью их среди молодёжи Среднего Поволжья. Междугороднее соревнование состоялось в начале марта 1916 г. на льду р. Казанка в 300 метрах от спуска на улицу Подлужная от Родионовского института. В соревнованиях приняли участие команды гг. Казани, Самары и две команды Симбирска. Трёхэтапную эстафету (5+10+15 верст) выиграла команда Самары с результатом 2 часа, 4 минуты, 29 сек. [18]. 1 февраля 1928 г. на Чёрном озере состоялся финиш «звёздного» лыжного пробега. Первыми финишировали лыжники Свияжска, вторыми - Арска, третьими - Буинска (город в северной части Симбирской губернии) $[18,19]$.

Благодаря стараниям 30 молодых людей Губернское присутствие 11 октября 1914 г. постановило Алатырского спортивное общество «Стрела» внести в реестр обществ и союзов по Симбирской губернии. Цель сообщества: поощрение различных видов физических упражнений: 1) игр как: футбол, хоккей, лаунь-теннис, лапта, городки и проч.; 2) упражнений в легкой атлетике, как: бег, прыжки, метания, ходьба и проч.; 3) гимнастических упражнений; 4) зимнего спорта: коньки, лыжи; 5) прогулок [11]. В обществе не допускались никакие игры с денежными ставками. Членами общества могли быть лица обоего пола, достигшие совершеннолетия, в неограниченном количестве, за исключением несовершеннолетних, учащихся в низших и средних учебных заведениях и состоящих на действительной службе нижних членов и юнкеров, лиц исключенных из какого-либо другого спортивного общества, лиц ограниченных в правах по суду и находящиеся под судом и следствием по преступлениям, влекущим ограничение в правах. Все члены общества платили взносы. Для достижения своих це- 
лей члены общества читали лекции, проводили беседы, издавали печатные материалы. Организовывали обучение физических упражнений, состязания, испытания. Устраивали концерты, спектакли, балы, маскарады и другие общественные увеселения. Мероприятия проходили бесплатные и платные, сбор с которых предназначался на пополнение казны общества [11].

В августе 1916 г. симбирские легкоатлеты приняли участие в первой Поволжской олимпиаде, проходившей в Нижнем Новгороде. Результаты симбирских спортсменов превзошли все ожидания. Самый известный симбирский спортсмен В.Н. Сивинцев занял сразу шесть призовых мест - первые места в прыжках с шестом (установив Поволжский рекорд 2,7 м), прыжках в длину и беге на 400 м, вторые - в беге на 1500 и 5000 м и в тройном прыжке. Вместе с другими спортсменами (М. Кудряшовым, Н. Кудряшовым, М. Узюковым) он стал победителем и в эстафете на 100, 200, 400 и 800 м. В 1917 году именно Сивинцев возглавил Симбирский филиал Поволжского олимпийского комитета, работал он в городе и в советское время $[6,11]$.

Лекции и народные чтения в информационном пространстве поволжского города в годы первой мировой войны. В г. Астрахани 8 ноября 1915 г. при содействии Гимнастического общества «Сокол» в зале Городской думы преподаватель гимнастики из г. Баку Л.А. Романченко прочитал публичную лекцию «Искусство плавания и его значение» [14].

Советская Россия. В поволжских городах (Самара, Царицын, Сызрань, Симбирск) власть Советов установилась мирным путем. В Западной Сибири Советы взяли власть лишь в декабре 1917 г. [4]. Одним из российских феноменов начала XX в. являлось зарождение советской физической культуры. Многие спортсмены, врачи, интеллигенция, педагоги, журналисты и общественные деятели, активисты спорта не покинули страну в 1920-х гг.: тяжелоатлеты - питерские братья Пендер, М.М. Рассо-Ермолов, борец А.В. Северов, легкоатлеты - М.Л. Бархаш, Н. Владимиров, Б. Котов, Н.А. Хорьков, лыжники - М.М. Гостев, А.И. Немухин, и др. Они пережили трудное время и продолжали участие в спортивной жизни государства $[3,17]$.

1920-е гг. Отрицание прежней теории спорта и агрессивная пролетарская идеология способствовали формированию новой нормативно-правовой базы [25]. Правительство учредило Высший и Местные Советы Физической Культуры. В Симбирской губернии МСФК взаимодействовал с Всеобучем с целью заинтересовать людей развивать физическую культуру региона. Обсуждалось сохранение тенниса, футбола, баскетбола по причине присутствия в них процессов состязания и соревнования. Из-за неудовлетворительного здоровья молодого поколения организовывались спортивные игры [4]. ВСФК устраивал всеобщие спартакиады, они освящались в Симбирской губернии в изданиях: 1922-1923 гг. - «Всеобуч и спорт», «Спорт» и др. Это популяризовало физкультуру среди граждан и способствовало повышению доверия населения советскому правительству.

В занятиях физической культуры населения доминировала гимна- 
стика, по причине малой потребности в тренажерах, исключение - аппаратная гимнастика. Устраивались соревнования прыжках с разбега среди мужчин, по баскетболу, футболу, легкой и тяжелой атлетике (в протоколах не значилась категория тяжелого веса, им только начинали интересоваться граждане. Максимальный жим двумя руками составил 199 кг, минимальный - 134 кг), мероприятия по самообороне [17]. Для полномасштабного влияния спорта на общественную жизнь провинции организовывались спортивные кружки. В 1924 г. был принят декрет о физкультуре, расширивший количество ведомств, обязанных проводить различные активные общественные мероприятия. Строились спортивные площадки для массового развития спорта. После городской олимпиады последовало другое знаменательное событие - баскетбольный чемпионат г. Ульяновска. В нем принимали участие все существующие на то время баскетбольные команды города. Лучшие - КиСи и УтКом [17]. В общественной жизни граждан доминировали турниры по шахматам и шашкам, так как они требовали относительно небольших материальных затрат при подготовке. Только в 1923 г. стали появляться общие соревнования, в 1924 г. стали проводиться и губернские чемпионаты по летним видам спорта.

Формируется женский спорт в городе, провинции, деревнях: атлетки часто выступали во время праздников. Пресса сообщала об общественной работе женщин в различных профессиональных сферах: «В недалеком прошлом не заметные домашние хозяйки, они берутся за руль мотоцикла и совершают первый в истории женского спорта трудный мотопробег»; «25 июля закончился большой 8-км-вый пробег жен начсостава ЛВО по маршруту Ленинград - Псков - Ленинград. По пути жены командиров обследовали столовые, ясли и красные уголки в лагерях» [17].

В 1923 г. открылось спортивное клубное учреждение. В 1925 г. окончательно сформировались внутригубернские чемпионаты по футболу и баскетболу, получили массовое развитие новые виды спорта - борьба, хандбол. Устраиваются межгубернские спортивные мероприятия - футбольный матч городов Казань - Ульяновск. В газете «Пролетарский путь» публиковались лекции докторов, посвященные развитию физической культуры с учетом биологических особенностей человека [17].

С 1926 г. стали проводиться медицинские медосмотры у атлетов, устраиваются всегубернские зимние соревнования, где доминировал популярный у населения края лыжный спорт. В 1928 г. состоялся лыжный забег на 80 км. Улучшение финансирования спортивных состязаний способствовал развитию водного, конного и велоспорта, функционировали тиры. Открыли новые площадки - водную станцию и стадион.

Голод в 20-х гг. ХХ в. сказался на здоровье симбирских школьников. Требовалось срочно предпринимать меры по улучшению здоровья голодающего населения и эпидемиологической ситуации в Симбирской (Ульяновской) губернии. [7]. Всесоюзная периодика способствовала организации в деревнях тематических вечеров для молодежи, создавались все условия для добровольного участия граждан в спортивной жизни региона. Увели- 
чивалось количество партийных и спортивных кружсков при избах-читальнях, совхозах, фабзавучах и других учреждениях [17].

В крае проходили соревнования по легкой и тяжелой атлетике, по конному, водному и велоспорту, по самообороне, спортивные олимпиады, чемпионаты по футболу и баскетболу, шахматные и шашечные турниры. Количество крупных спортивных мероприятий в г. Симбирске росло: 1921 г. - 4, 1922 г. - 2, 1929 г. - 27, 1930 г. - 31 [17]. Проведение государственных празднеств уже не мыслилось без массовых выступлений представителей спортивных кружков и клубов. В конце десятилетия спорт был полностью включен в культурную жизнь горожан.

К началу 1930-х гг. расширилось количество спортивных кружков во всех поселениях провинции, деревнях. В условиях культивирования советского коллективизма пропагандировались и развивались, в первую очередь, командные виды спорта - футбол, гребля, легкая атлетика.

Во второй половине 1930-х, в атмосфере идеологической подготовки к войне молодежь увлекалась военизированными видами спорта - парашютным и стрелковым, стремилась заслужить значок ГТО и с гордостью носить его. Множество горожан стала спортивными болельщиками, самым зрелищным и популярным видом спорта был футбол [12]. Спортивные соревнования устраивались и в праздники. В план подготовки и проведения 12 сентября 1948 г. 300-летнего юбилея Симбирска входило провести на стадионе «Спартак» соревнования по различным видам спорта, посвященные юбилею [13].

\section{References:}

[1] Анашкина Г.П. Досуг интеллигенции в Ульяновске // Социологические исследования. 2001. № 12. С. 97-103.

[2] Гавлин М.Л. Из истории российского предпринимательства: династия Фон Мекк // История России. Серия аналитических обзоров и сборников. 2000. № 2. С. 1 76.

[3] Голотин, А.В. Культура Симбирской (Ульяновской) губернии в 20-е годы XX века: история, процессы, проблемы: автореф. дис. ... канд. культурологи. 24.00.01. Саранск, 2014.

[4] История России. 1914-1922 / С.И. Голотик, С.В. Карпенко, Т.Ю. Красовицкая, В.В. Минаев, А.С. Сенин // Учебно-методический модуль Сер. Я иду на занятия... М.: Изд-во Ипполитова, 2015. 366 с.

[5] Громова Т. Яхт-клуб в Симбирске // Деловое обозрение. №5 (112). Май 2007 // http://uldelo.ru/2016/04/19/yakht-klub-v-simbirske

[6] Громова Т. Симбирск спортивный // Деловое обозрение. №5 (88)-май 2005 г. http://uldelo.ru/2016/04/19/simbirsk-sportivnyi

[7] Гуркин В.А. Голод 1920-х гг. в Поволжье в зеркале местной прессы // Проблемы социально-экономического, политического и культурного развития России. Вып. 4: сб. научн. тр. / под ред. С. В. Осипова. Ульяновск: УлГТУ, 2010. 88 с.

[8] Дневник 1907. Литературное наследство. 1979. Том 90. №-2. С. 346-606.

[9] Дневник 1910 / Т.Н. Волкова, Н.И. Азарова, С.А.Розанова // Литературное наследство. 1979. Т. 90. № 4. С. 5-432.

[10] Зельдович В.Д. Доклады из Ярославля и Костромы // Литературное наследство. 1971. Т. 80. С. $375-445$. 
[11] Макарова Р.В. Молодежные общественные организации Симбирской губернии до 1917 г. (по документам государственного архива Ульяновской области) // Youth World Politic. 2014. № 2. C. 28-33.

[12] Мухина 3.3. Семейный быт и повседневность крестьян Курской губернии: традиции и динамика перемен в пореформенной России. М.: ИЭА РАН, 2012. 299 с.

[13] Романова Г.В. От «града Синбирска славного и похвального» до Ульяновска родины В.И. Ленина: документальный калейдоскоп / Симбирский научный вестник. 2013. № 2 (12). С. 174-191.

[14] Семенова Е.Ю. Лекции и народные чтения в информационном пространстве поволжского города в годы первой мировой войны (1914 начало 1918 г.) / Е.Ю. Семенова // Известия Самарского научного центра Российской академии наук. 2012. T. 14. №3-1. С. 38-44

[15] Семенова Е.Ю. Виды и формы досуга горожан Поволжья в годы первой мировой войны // Известия Самарского научного центра Российской академии наук. 2013. T. 15. № 1-1. С. 60-67.

[16] Таиров Н.И. Татарские предприниматели Поволжья и Приуралья и национальные праздники (2 пол. XIX- нач. XX вв.) // Вестник Казанского гос. университета культуры и искусств. 2015. № 1. С. 126-128.

[17] Тихонова А.Ю., Голотин А.В. Культура Симбирском (Ульяновской) губернии в 20-е гг. ХХ века: история, процессы, проблемы. Ульяновск. 2015. 223 с.

[18] Файзрахманов Р.Ш. Хроника генезиса и развития лыжного спорта в Татарстане (н. XX в. 1920-е гг.) / Р.Ш. Файзрахманов, Н.Д. Бобырев // Современные проблемы и перспективы развития системы подготовки спортивного резерва в преддверии XXXI олимп. игр в Рио-де-Жанейро. 2015. С. 466-468.

[19] 19. Буинский муниципальный район. Официальный портал Татарстана. http://tatarstan.ru/ /http://buinsk.tatarstan.ru/o_rayone/istoriy.htm

[20] 20. Зарождение конькобежного спорта в Казани 1900-1917 гг. // Спорт в Казани (12+). http://sport-in-kazan.ru/zarozhdenie-kon-kobezhnogo-sporta-v-kazani1900-1917-gg/

[21]21. Досуг городской интеллигенции на рубеже 19-20 веков // https://adsl.zveronline.ru/projects/articles/2009/01/15/dosug/

[22] В канун 1912 года. Зимние праздники в Самаре // http://kraeham.livejournal.com/56333.html

[23] 23. Громова Т.A. С Симбирском связаны судьбой: (женщины в истории Симбирской губернии XVIII начала XX веков: рассказы). Ульяновск: Корпорация технологий продвижения, 2015. 207 c.

[24] Фото И. Заикина. http://www.liveinternet.ru/users/ertata/ post290354335/

[25] Зуев В.Н., Куценко Я.А. Становление и развитие физического воспитания в учебных заведениях Топольской губернии на рубеже XIX-XX века // Вестник Тюменского государственного университета. Гуманитарные исследования. Humanitates. 2013. № 2. C. 145-154. 


\title{
ECONOMICS
}

\section{INCREASE IN INVESTMENT APPEAL JOINT-STOCK COMPANIES IN UZBEKISTAN}

\section{B. Usmanov ${ }^{1}$}

\begin{abstract}
In article the theoretical points of view of scientists-economists about «investments», «investing activities» and «investment appeal» are considered. Proceeding from the points of view of scientists-economists, the investment strategy of the state is proved, and also enhancement of mechanisms of activities regarding corporate and joint-stock activities is offered. The main indicators of the industry of the Republic of Uzbekistan and structure of investments on industries are analysed.
\end{abstract}

Keywords: investment, investment policy, investment appeal, joint-stock company, foreign investor, corporate governance.

It is known that each country aims to create the most attractive investment climate: sets a favorable tax regime, develops the legislation, creates conditions for the fair competition and high-quality infrastructure for business development, enters the minimum administrative barriers.

Meanwhile, calculations of world analysts show that in emerging markets in the next decade growth of deficit of capital stock is expected. So, in the outlined dynamics of development of the financial markets demand and supply gap from 2008 for 2022 will constitute about 8 trillion US dollars [8, p. 9].

In the conditions of the continuing global financial crisis the economy of the Republic of Uzbekistan shows the remaining growth rates of the main economic indicators with high social support of the population. «The most important instrument of dynamic and balanced economic growth, implementation of deep structural transformations and diversifications of economy is carrying out active, address investment policy» [4].

These words of the First President of the Republic of Uzbekistan I.A. Karimov become a driving force of activities of joint-stock companies of real production sector in ensuring preserving stable indicators of growth of national economy in 2015 and the next years.

In particular, the complex measures for upgrade, technical and technological updating of productions and increase in competitiveness of industries realized in Uzbekistan provided growth of production volume of industrial output in

1Bunyod Usmanov, student, Tashkent State University of Economics, Republic of Uzbekistan. 
2015 for $7,9 \%$ relatively 2014 . The specific weight of the industry in general investments of the country made $40,9 \%$, i.e. this indicator is 3,5\% higher, than for the accounting period of last year. Due to high-quality changes the specific weight of the industry in GDP made 24,3\% (table 1). Dynamic development of the industries oriented to production with a high value added is provided.

Table 1

The main indicators of the industry of the Republic of Uzbekistan

for 2008-2015.

\begin{tabular}{|c|c|c|c|c|c|c|c|c|}
\hline & \multicolumn{7}{|c|}{ Years } \\
\cline { 2 - 9 } Indicators & 2008 & 2009 & 2010 & 2011 & 2012 & 2013 & 2014 & 2015 \\
\hline The share of industry in GDP, \% & 23,5 & 23,6 & 23,9 & 24,0 & 24,0 & 24,1 & 24,0 & 24,3 \\
\hline $\begin{array}{c}\text { The growth rate of industrial } \\
\text { production, \% Compared to the } \\
\text { previous year }\end{array}$ & 112,7 & 109,1 & 108,5 & 106,4 & 107,9 & 109,6 & 108,3 & 107,9 \\
\hline $\begin{array}{c}\text { Specific weight of the industry } \\
\text { in general investments of the } \\
\text { country, \% }\end{array}$ & 34,5 & 28,4 & 30,4 & 33,8 & 34,2 & 34,2 & 37,4 & 40,9 \\
\hline $\begin{array}{c}\text { Share of the in industry in } \\
\text { employment in the economy, \% }\end{array}$ & 13,5 & 13,4 & 13,2 & 13,1 & 13,0 & 12,9 & 12,8 & 12,8 \\
\hline
\end{tabular}

Source: Industry of Uzbekistan. Statistical collection. - Tashkent: State Statistics Committe of the Republic of Uzbekistan, 2012-2016. - P.14.

In 2015 at the expense of all sources of financing in the industry of Uzbekistan it is mastered investments of 17041,0 billion sum that is twice higher than a similar indicator of 2012. In industry structure the share of investments in fuel industry from 39,1\% in 2012 increased to 52,9\% in 2015. The same indicator in the energy sector increased according to $10,7 \%$ up to $11,3 \%$. At the same time the share of the investments directed to mechanical engineering and metal working decreased: from $11,8 \%$ in 2012 to $5,4 \%$ in 2015 ; metallurgy: from $8,2 \%$ to 5,5\%; light industry: from $8,6 \%$ to $4,4 \%$; chemical and petrochemical industry: from $6,7 \%$ to $5,8 \%$; food industry: from $4,9 \%$ to $4,0 \%$; industry of construction materials: from $5,3 \%$ to $4,3 \%$ (Fig.1.).

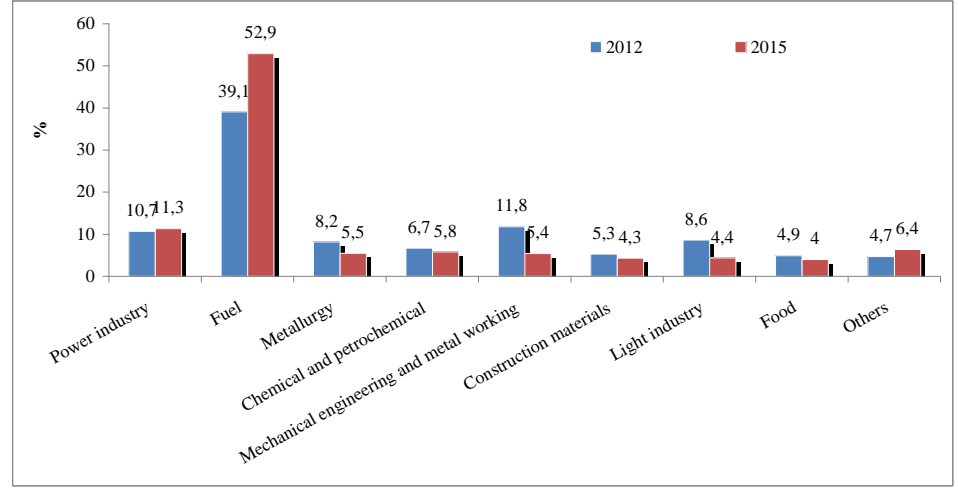

Fig.1. Structure of investments on industries

Source: Industry of Uzbekistan. Statistical collection. - Tashkent: State Statistics Committe of the Republic of Uzbekistan, 2016. - P.44. 
For studying of investment appeal of joint-stock companies, it is necessary to analyse in detail such key economic categories as «investments», «investing activities» and «investment appeal». The necessity of such analysis is caused by availability of a set of value judgment of various scientists often contradicting each other. It as S.S. Zhilinsky truly notices, absolutely inadmissibly as similar inconsistency is capable to create any misunderstanding in economic and right realizable practice and to lead to preventing of activization of investment processes in national economy [1, p.69].

Investments are other on the concept than savings, and scientists-economists on this matter already made accurate differentiation. In particular, according to V.V. Kovalyov, under favorable conditions for development of economy and society, a low risk degree, the majority of the savings used on receipt of useful effect become investments [2, p.13]. It should be noted that now such conditions are created in developed countries, but as a result of the latest foreign policy events, and the related sanctions decisions concerning some countries, there is a restriction of world money turnover from subsequent its involvement in global investment process.

For the purpose of receipt of the most detailed idea of economic category «investments» and for increase in efficiency of their use it is representable the advanced classification of investments received in an analysis result of classifications of investments of I.A. Blanc, V.V. Kovalyov, G.S. Staroverova and L.L. Igonina and also allocations of an additional sign the «reached efficiency» characterizing a ratio of the spent investment resources and the gained effects [6, p.155-161].

It is possible to carry to the most important signs of investing activities:

- subordination of production (operational) activities for creation of conditions of its growth;

- smaller degree of dependence on industry features in comparison with productive activity;

- unevenness of amounts on the separate periods;

- «a delay log» when forming profit of the entity (and also other forms of effect);

- forming of an independent type of the cash flows of the entity which are variously sent to the separate periods;

- investment risk;

- the indicator of net investments (a difference of gross investments and the depreciation charges) characterizing rates of economic development of the entity [3, p.19-22].

In economic literature the concept «investment appeal» appeared relatively recently and is used mainly in case of the characteristic and assessment of investment objects, rating comparisons, the comparative analysis of processes [7, p.71-76].

As the analysis of domestic and western literature revealed that there is no consensus in an interpretation of determination of this economic category, in our opinion, it is necessary to pay special attention to its intrinsic characteristics for the purpose of receipt of due theoretical reasons.

In a broad sense investment appeal represents contradictory unity of two 
characteristics: economic content (investment) and a psychological form (appeal) - value judgment of objective reality (as the subjective factors influencing decision making about investment it is necessary to consider value judgment by the investor of indicators of a condition of an accounting entity and individual tendency to risk) [5, p.15].

Traditionally a concept investment appeal means availability of such conditions of investment which influence preferences of the investor in the choice of this or that investment object.

Proceeding from above the described scientific points of view of scientistseconomists, attraction of direct foreign investments shall be in the way a basis of an investment strategy of the state today:

- international cooperation of productions which is followed by transfer of modern technologies;

- creations of the entities with absolute foreign participation;

- implementations of shares of the privatized entities.

As more than $80 \%$ of industrial assets are concentrated in the joint-stock companies formed by privatization and privatization, adoption of the resolution of the President of the Republic of Uzbekistan of 21.12.2015 No.RP-2454 «About additional measures for involvement of foreign investors in joint-stock companies» which approved an order with which in compliance in joint-stock companies the share of the foreign investor in the authorized capital shall constitute at least 15 percent became logical continuation, the complex work on enhancement of corporate governance which is carried out in 2015 as necessary element of increase in investment appeal of the Uzbek joint-stock companies.

The main problem in involvement of foreign investors in the mentioned jointstock companies is that all of them are in structure of branch associations, regardless of how the last are called: joint-stock companies (JSC «Uzbekenergo», JSC «Uzkimyosanoat», JSC «Uzbekiston temir yullari», JSC «Uzbekengilsanoat», JSC «Uzbektelekom»); joint stock companies (JSC «Uzmaxsusmontajkurilish», JSC «Dori-darmon») and, in fact, are holding companies, also as well as $\mathrm{NHC}$ «Uzbekneftegaz», HC «Uzagrosanoatmash-holding», HC «Uzvinosanoat-holding», with all that it implies from this features in structure of capital stock and corporate governance. All entities which are a part of the vertically integrated holdings are affiliated and packets of their shares (from 51 to 100 percent) are controlled by mother company on the property rights.

These associations need to enhance activities mechanisms regarding corporate and joint-stock activities and to realize a complex of the actions directed on:

- improvement of corporate governance by the entities, increases in a role of their supervisory boards, accounting of interests of all groups of shareholders;

- forming as a part of holdings (their managing companies) of specialized divisions (departments, managements, departments) which are responsible for all block of corporate questions of all entities of holdings;

- giving of real managerial functions to the supervisory boards regarding a strategic management and control with allocation for this purpose necessary financial, organizational, administrative, personnel and other resources (withdrawal from nominal nature of recommendations); 
- inclusion of the supervisory boards in process of coordination of interests, both all groups of shareholders, and other concerned parties (regional authorities, partner entities, other entities of holdings, etc.);

- attraction in structure of the supervisory boards of qualified specialists in the field of corporate governance (as a rule, from structure of personnel of managing companies of holdings), the organization of training process of members of recommendations and the corresponding personnel of the entities (corporate consultants, legal services, etc.);

- development and acceptance as qualitatively new and corresponding to the modern legislation internal corporate documents of the entities leading (charters, regulations on bodies of corporate management, various codes, etc.);

- implementation of practice of regular holding internal meetings of the supervisory boards with consideration of real questions of activities of the entities (control of management, the current financial and economic activities of the entities, a budgeting system and business planning);

- carrying out restructuring of all business of the entities with involvement of qualified specialists, including restructuring of a management system by the entities on the basis of the modern principles of management;

- reduction of activities of the entities in compliance with requirements of the modern regulatory framework regulating questions of corporate governance including regarding practice of disclosure of information on activities of the entities (quarterly reports of issuers, essential facts, etc.);

- implementation of practice of real participation of the supervisory boards in preparation of general shareholder meetings (preliminary consideration of all documents to meetings, etc.);

- implementation of practice of coordination with the supervisory boards of candidates for key positions in a management of the entities.

\section{References:}

[1] Zhilinsky, S.S. Concept «investments» of the modern Russian legislation / Legislation. Moscow: 2005. №3. P.69.

[2] Investments. The textbook / Under the editorship of V.V.Kovalyov, V.V.Ivanov, V.A.Lyalin. M.: LLC Shopping Mall Velbi, 2003. 440 p.

[3] Investment management / Blanc I.A. M.: Elga, Nika Center, 2001. 448 p.

[4] Karimov, I.A. Creation in 2015 year ample opportunities for development of a private property and private entrepreneurship by implementation of radical structural restructurings in national economy, consecutive continuation of processes of upgrade and diversification - our priority task // «Pravda Vostoka», №11 of 17.01.2015.

[5] Ramenskaya L.A. Economic evaluation and increase in investment appeal of accounting entities of forest sector. Abstract of dis. ... cand.of econ.science: 08.00 .05 / L.A.Ramenskaya. Moscow, 2009. p.15.

[6] Romanov, A.A. Concept, classification of investments, difference from investing activities // Topical issues of economic sciences: collection of materials XXIX of the International scientific and practical conference: in 2 parts. Part 2. Novosibirsk: LLC agency «SIBPRINT», 2013. P.155-161.

[7] Tarelkin, A.A. Features of determination of investment appeal of the entities of real production sector and management of this process in the conditions of financial crisis 
/A.A.Tarelkin // Messenger of regional public institution. Moscow: 2010. №4. P.7176.

[8] Shvyrkov, O.G. Corporate governance as instrument of growth of investment appeal of the companies // Magazine «Joint-stock company: questions of corporate governance». Moscow: 2013, №10. P.9.

[9] Industry of Uzbekistan. Statistical collection. Tashkent: State Statistics Committe of the Republic of Uzbekistan, 2012-2016. 


\title{
PRACTICE OF ECONOMIC ANALYSIS METHODS IN RESEARCHES OF INFORMATION CONFRONTATION
}

\author{
G. Tsvetkova ${ }^{1}$, A. Eshpoldina ${ }^{2}$ \\ DOI: http://doi.org/10.15350/L_26/9/5
}

\begin{abstract}
The paper demonstrates the use of economic methods in researches of information confrontation of countries. The dynamics of population size and internet users growth in Russia and the United States is compared on the basis of horizontal analysis tools. Comparative analysis of the budget and costs structure on information confrontation, positioning of countries on key indicators of global competitiveness showed catch-up strategy of Russia's development.
\end{abstract}

Keywords: economic analysis, statistical methods, horizontal analysis, information confrontation, network warfare.

Nowadays, information confrontation of countries across the world is conducted at a qualitative level, and network warfare is one of forms of this confrontation. Network warfare is not only the area of geopolitics, it covers more wide range of involvement of different spheres, ranging from the military forces and the diplomatic channels, ending with information sphere, psychology and inner world of human. The economy and finances are acting as the object of information confrontation and cyber-attacks. It implies active use of economic tools in researches of given processes (Table 1).

Table 1

Technology of network warfare in the World economy

and International finance

\begin{tabular}{|c|l|}
\hline Purpose & Damage to economy, information dominance. \\
\hline $\begin{array}{c}\text { Opperations } \\
\text { (covert) }\end{array}$ & $\begin{array}{l}\text { Country's economy (monetary-policy tools and financial rela- } \\
\text { tions) }\end{array}$ \\
\hline Industrial espionage (access to sensitive information), specula- \\
$\begin{array}{c}\text { tive attacks, organization of wars, revolutions, "orange" sce- } \\
\text { nario, provocations, fraud, manipulations, trolling. }\end{array}$ \\
\hline Means & $\begin{array}{l}\text { Diplomatic channel - economic diplomacy, shadow effect } \\
\text { (opinions), direct effect (sanctions). }\end{array}$ \\
\hline $\begin{array}{l}\text { Mass media, Internet usage (twitter, Facebook, Google), cyber- } \\
\text { attacks, attacks from hackers, organization of financial and } \\
\text { trading systems failures, freezing of bank accounts. }\end{array}$ \\
\hline
\end{tabular}

Based on data from the article of Smirnov F.A. Network warfare in the world economy and international finance [7].

\footnotetext{
${ }^{1}$ Galina Tsvetkova, Candidate of Economic Sciences, Associate Professor Mari State University, Volga State University of Technology, Russia.

${ }^{2}$ Anastasia Eshpoldina, Master's student, Mari State University, Russia.
} 
Economic analysis tools are based on three main areas of knowledge: mathematics, statistics, and economics. Within this article we present examples of the statistical methods use in the research of information confrontation between the United States and Russia. Statistical methods are based on the average and relative values, the index method, correlation and regression analysis. The chain growth rates of the internet users number and the chain growth rates of population have been calculated to demonstrate the economic tools (Table 2).

Table 2

Growth rates (chain) of population and the internet users in Russia and the USA, 2008-2015,\%

\begin{tabular}{|l|c|c|c|c|c|c|c|c|}
\hline & $\mathbf{2 0 0 8}$ & $\mathbf{2 0 0 9}$ & $\mathbf{2 0 1 0}$ & $\mathbf{2 0 1 1}$ & $\mathbf{2 0 1 2}$ & $\mathbf{2 0 1 3}$ & $\mathbf{2 0 1 4}$ & $\mathbf{2 0 1 5}$ \\
\hline $\begin{array}{l}\text { Popu- } \\
\text { lation } \\
\text { size } \\
\text { of } \\
\text { Rus- } \\
\text { sia }\end{array}$ & 99,96 & 100,035 & 100,04 & 100,08 & 100,17 & 100,2 & 100,2 & 100,209 \\
\hline $\begin{array}{l}\text { Inter- } \\
\text { net } \\
\text { users } \\
\text { in } \\
\begin{array}{l}\text { Rus- } \\
\text { sia }\end{array}\end{array}$ & 108,8 & 108,09 & 148,28 & 113,95 & 130,2 & 106,53 & 103,75 & 104,09 \\
\hline $\begin{array}{l}\text { Popu- } \\
\text { lation } \\
\text { size } \\
\text { of the } \\
\text { USA }\end{array}$ & 100,95 & 100,88 & 100,84 & 100,76 & 100,77 & 100,74 & 100,78 & 100,79 \\
\hline $\begin{array}{l}\text { Inter- } \\
\text { net } \\
\text { users } \\
\text { in the } \\
\text { USA }\end{array}$ & 108,8 & 108,09 & 148,28 & 113,95 & 130,2 & 106,53 & 103,75 & 104,09 \\
\hline
\end{tabular}

Calculations based on data from The World Bank [8].

Statistical methods allow making a comparison of the investigated data and facts of the socio-economic life. It should be noted that the prerequisite for comparative analysis is a compatibility of compared indicators, involving: the unity of volume, cost, quality, structural indicators; the unity of the periods of time for which the comparison is made; compatibility of methodology for calculating indicators.

Practice of economic analysis tools in the researches of political processes allows to give the characteristics of main subjects of political processes, resources, methods and conditions of their interaction and also to give the logical sequence of this interaction. Furthermore, the political process factors, equilibrium level, space and time of its development can be identified as policy process parameters. An important aspect of political process analysis is the identification of its statistic and dynamic characteristics.

Economic methods give a "picture" of the political process at a particular time. Statistical representation about the political process parameters is typi- 
cal for economic analysis of political situation. Such analysis identifies a system of ties and relations between main elements of the political process, which was established by the particular moment. Thus, it forms a basis for comparison of several political situations, different during time. In other words it creates the basis for reveal of the political process dynamics (features of political change) [5].

The development analysis of political process is very essential for revealing of dynamic characteristics. Similar analysis can be carried out using tools developed in the framework of such scientific approach as analysis of political discourse. In addition, enough interesting results for representation the process dynamics gives the application of methods of formal modeling, game theory as well as theory of political decision-making [1, p.83].

Combination of statistical and dynamic approaches of analysis can be compared with the production process and viewing of the videotape. Every separate frame describes a particular situation. On base of the review of each separate frame, to some extent we can characterize the main actors, the nature and conditions of their interaction, etc. However, this analysis will be incomplete: it will be similar to the photo, devoid of dynamics and context. Only by viewing series of rapidly changing frames, we can provide a complete picture of the plot, dynamics and also the basic parameters of the ongoing process.

An important element in the study of the statistic and dynamic characteristics of political process is the analysis of its external environment, which includes social, economic, and cultural factors influencing the political process, as well as political change at higher levels.

Let's imagine an example of horizontal analysis. This analysis allows comparing the dynamics of dissimilar processes through growth rates.

Horizontal comparative analysis is applied to determine the absolute and relative deviations of the actual level of the studied parameters from the base deviation. The presented below graph of dynamics of Internet users number in China, UK, Germany, Russia and the United States for 1997-2015 demonstrates the level of the Internet usage in different regions (figure 1).

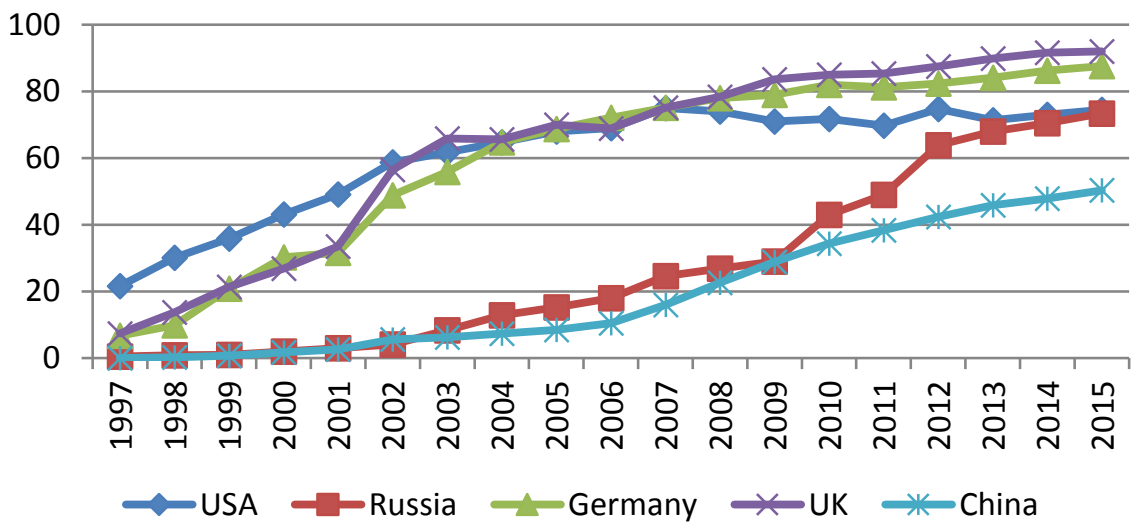

Figure 1. Dynamics of Internet users, 1997-2015, \%.

In 1997 the USA was the leader in the number of internet users. China is lagging behind in the number of Internet users compared with other countries. 
The UK became the leader by 2015 .

It should be noted that today there are about 4 billion internet users in the world, and it is particularly significant that the Internet has no limits and its possibilities are infinite. By no means all users understand which threats it carries and how the information security is implemented. The criminal use of information and communication technologies and its use for terrorist and military and political purposes is widely distributed. The further discussion of this important topic which affects the national security of the United States and Russia in the field of cyber security became impossible in connection with the sanctions against Russia [4, p.22].

Business is also a victim of cybercrime. There is not only increase in the number of attacks, but also a range of platforms which are exposed to this. If a few years ago the bulk of the attacks occurred at the corporate level, today there is an increasing tendency of attacks on private individuals. The malicious programs for smartphones help cybercriminals to get access to e-wallets and online banking systems that are connected to smartphones and tablets. Nearly half of all cyber-attacks are committed against such segment of economy as private individuals and small businesses, because they can't afford reliable protection against hackers [3, p.45].

Each Russian company loses \$ 3 million a year on average. The American companies suffer from cyber-attacks more than others. They lose more 12,5 million dollars in the course of year. The average figure around the world is less than $\$ 5.5$ million for organization over the same period [6].

Network warfare affects not only corporate interests but also national interests. Cyber-attacks were widely used against Ukraine during the conflict in the East of the country in 2014. Cybercriminals had applied different types of attacks: unauthorized bugging, radio intercepts, mobile spam during elections. The recent accusations against the Russian Federation concerning the attack on the data base of the Democratic party of the USA in the midst of the election campaign also raise the issue of information security [2].

In the study by means of horizontal analysis, it is possible to identify the dynamics of various processes characterizing the development of information confrontation in all its diversity. For example, a comparative analysis of growth rates in population size and of growth rates in the number of Internet users clearly demonstrates the excess of the latter indicator in 2008-2014 years that can be characterized as a positive trend (Figure 2).

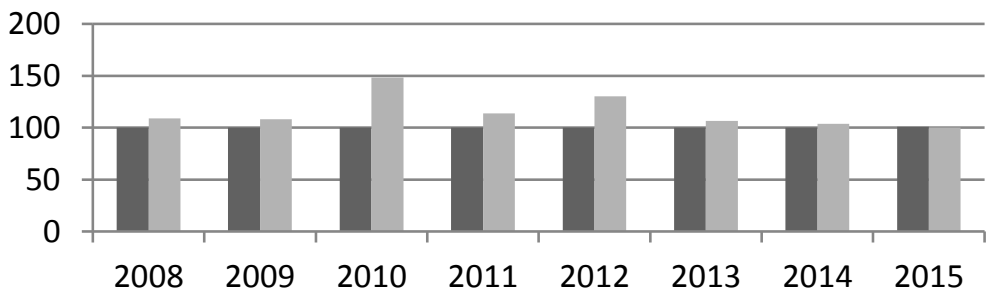

Population Internet users

Figure 2. Growth rates (chain) of population and the Internet users in Russia, 2008-2015, \%. 
In general, horizontal analysis is a convenient research tool of the processes of information confrontation of the USA and Russia.

Vertical analysis allows us to investigate a whole part through its elements, and to determine the share of each structural element. Figures 3 and 4 show the share of $R \& D$ expenditure, investment in telecommunications and information security from the total GDP of the US and Russia in 2015. Analysis provides an opportunity to conclude that the share of Russian investments in information security from GDP exceeds the share of US investments in similar items of expenditure.

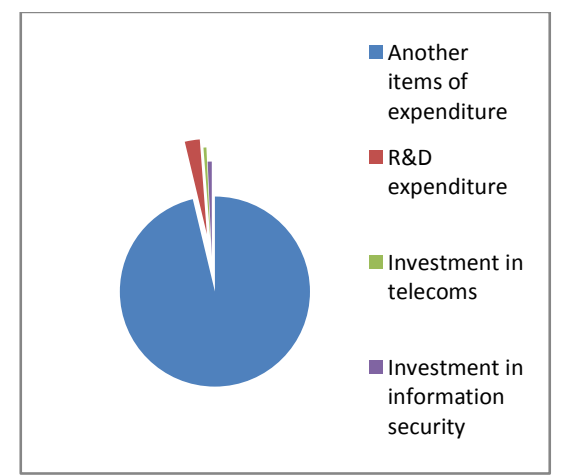

Figure 3. The US budget, 2015, \%.

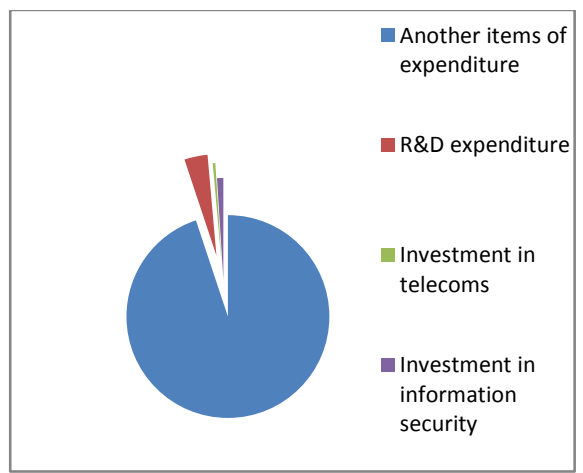

Figure 4. Russian budget, 2015, \%.

Methods of comparative analysis and perceptual maps are widely used in political researches. Perceptual map is a convenient way of visualizing the key characteristics of research objects. An individual case of perceptual map practice is "polygon of competitiveness". The method allows you to quickly analyze a country's competitiveness compared to key competitors.

In our example while constructing the polygon of competitiveness of the USA and Russia we used the following characteristics of country: level of prosperity, population size, Human Development Index, life expectancy, level of foreign direct investments, global competitiveness, Information and Communication Technology Development Index, level of Gross Domestic Product, Internet Development level, R\&D expenditure level. The open data of the following sites were used as research information base: The World Bank, International Monetary Fund, International Telecommunication Union, and Eurostat. The source indexes were converted to ten-point scale: where 1 is the lowest score and 10 is the highest. The next step is the polygon constructing on the basis of given estimates (Figure 5).

The polygon of competitiveness (perceptual map) makes possible to visually compare the parameters of Russia and the USA. Diagram shows the US dominance on many indicators (R\&D expenditure, life expectancy, prosperity level, Global competitiveness). At the same time Russia did not fall behind in the level of internet development and ICTs, and Russia is catching up the pace on other criteria. Thus, this method defines the problem area and the development directions. 


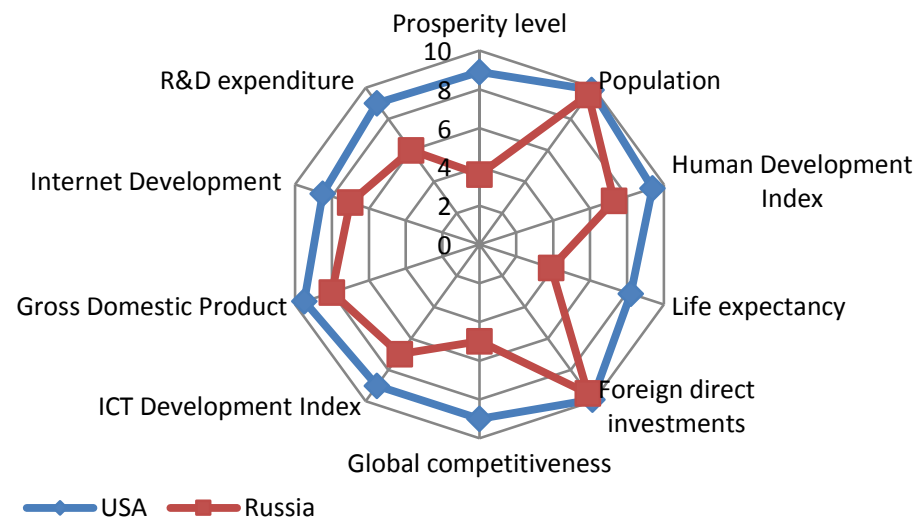

Figure 5. The USA and Russia's competitiveness level, 2015.।

Summarizing, we note that the economic analysis tool demonstrates the state of information confrontation of the USA and Russia, identifies the changes in impact objects, and the effectiveness of used tools and instruments.

\section{References:}

[1] Degterev D.A., Degterev A.H., Game theory and international relations. World Economy and International Relations, No. 2, P. 79-89, 2011.

[2] Janowski A. Cyber security: on what the global companies will spend \$ 76.9 billion. Available at: http://qps.ru/u2UYB, 2014.

[3] Kremer V.V. Cyber-attacks: Trends and Risks. Information security, No. 6, P. 45, 2015.

[4] Krutskikh A.V., Who owns the Internet, he owns the world. International Affairs, No. 11, P. 18-27, 2016.

[5] Meleshkina E.Yu. Political process: main aspects and analysis. Available at: http://qps.ru/c04dg

[6] Security Research Cyber risk Report 2016. Available at: http://qps.ru/gt5Dv

[7] Smirnov F.A. Network warfare in the world economy and international finance. Economic strategies, No. 4, p. 110-119, 2015.

[8] The World Bank. Available at: http://www.worldbank.org 
ANALYSIS AND PROGNOSTICATION OF ECONOMIC EFFICIENCY OF BUSINESS

ENTITY'S INTERNATIONAL TRADING UNDER UNCERTAIN ECONOMY

BASED ON THE MODELLING OF A LEARNING CURVE

\author{
O. Martyanova ${ }^{1}$ \\ DOI: http://doi.org/10.15350/L_26/9/1
}

Abstract

International trade under economic uncertainty requires enhanced prediction accuracy. In order to make it possible we suggest using the learning curve, since it allows calculating time and expenses necessary for the new types of products, which act as efficiency factors of the business entity's international trading. The paper presents the model of choosing the optimal pricing policy for the exporter introducing a new product on the market.

The model relies on the effect of the learning curve as the learning rate data are significant when determining the probable expenses, which will be incurred as a result of the international contract fulfillment. In order to increase the validity of the predictive estimate attained using a learning curve we suggest complementing its toolware with economic and mathematical modelling based on Markovian processes.

Keywords: learning curve, efficiency analysis, cumulative mean time, international trade, learning index, price, export contract, economic and mathematical modelling, Markovian process, final probabilities, normalizing condition.

Continuous demand of the business owners to increase profit in the context of depreciation of ruble, decrease of beer consumption, increase of excise duties and ever tightening regulation of the brewery sector on behalf of the state fosters the company management to have profound knowledge of the market as well as well-developed toolware necessary to make managerial decisions under economic uncertainty. Absence of structural changes in product category production are driven by consistent demand for the light beer which accounts for about $96 \%$ of the overall production, while non-alcoholic, non-filtered, special and dark beer account for only 4\% [4]. This provides rationale for working out accurate prognoses when launching a new beer brand. The performance efficiency of a business entity on the national and global market is defined by an array of factors including capacity analysis and operating expenses underlying budget formation, its implementation control and international trading project evaluation. We assume that the theory of the learning curve may be used for making such prognoses.

The learning curve represents a mathematical model of a phenomenon which means constant reduction of time rate required to produce one product unit

10lga Martyanova, Candidate of Economic Sciences, doctoral candidate The Orel State University of Economics and Trade, Russia. 
when the same labour intensive task is repeated in a series of trials. The learning curve may be represented as follows [1]:

$$
Y=a \times x^{b},
$$

Where $Y$ - the cumulative mean time per unit or batch,

$a$ - time per first unit or batch,

$x$ - cumulative quantity of units or batches,

$V$ - learn rate.

$$
b=\lg V / \lg 2-\text { learning index, }
$$

Production of the first unit is always more expensive than the $100^{\text {th }}$ unit, which comes as a result of several types of improvements, such as salaries expenses, resources and other overhead costs. We believe that one of the essential factors of operating efficiency of a business entity, including international trade is the effect of the learning curve which is not sufficiently analyzed in literature. We assume this to be an unreasonable flaw as the application of its concept facilitates making the optimal decision when prognosticating worktime costs and payment aimed at cost saving. The learning curve is essential when evaluating strategic target indicators, since the effect of its application makes it possible to calculate variances relevant to budgetary control, thus releasing the business entity involved in international trade from labor intensive definition of fixed standard variances applied to resources, materials, labor and variable overhead costs on account of their inexpedience. If the learning curve is not defined, the efficiency deviation will be useless for monitoring purposes [3, p. 100].

However, the learning curve has certain disadvantages, because it doesn't simulate the long-term dynamics of the production processes for cases in which there is no economic efficiency enhancement as a result of experience gained. Therefore, the data on the learning rate may be inaccurate before the large-scale production is launched. The following factors exert a significant impact on the learning process: employee turnover, change in staff motivation, long term breaks, downtime in production of product batches which diminish the effect of learning. We believe that learning cannot be deemed as a hands-off process, as it may be successful, on condition that the attention is focused and there is willingness to increase workforce productivity. Therefore, the companies with the same or similar material and workforce recourses might eventually attain different learning level. It is explained by the fact that the environment facilitating education is formed by the top management of the business entity and its corporate culture. So, the traditions of a business entity may be established regardless of a certain employee, thus preserving in a company even under workforce turnover.

We argue that the rate of production processes with repeated series of manual operations may be increased by training personnel in the course of work. The actual learning rate may be defined by observation in which the units produced and the time consumed are carefully considered and subsequently constitute the 
basis for the learning curve model.

When carrying out international trading the impact of the curve should be taken into consideration in budget preparation stage, setting the parameters of export-import operations. This is mainly because the normative expenses characterize the point of the learning curve in which the business entity doesn't feel this effect due to its inessentiality, which means that the party involved in international trade has attained its sustainable position on the global market with its inherent expenditure level which is a way below the value attained during personnel learning stage, characterized by a considerable value of occurring variances.

We believe that learning curve knowledge makes a business entity strategically competitive on the global market which "in many ways defines the efficiency of its operation" in the sphere of international trade. In order to establish "...the whole complex of financial, economic, organizational, managerial, production and technological business processes is aimed at ...sustainable manageable competitive advantages for the long-term development perspective" [5, p. 12]. The procedure of the optimal decision making related to the launch of a new brand is illustrated by the example to follow. It is based on the expenditure analysis taking into consideration the learning curve.

The managerial report data of the upmarket brewery company exporting its goods abroad were taken as the information background for our research. Due to the change in economic situation followed by the temporary reduction of the brewery business, the company decided to launch a new beer brand in order to extend the product line of upmarket brand profile. The expenses incurred by the company during the lifecycle of this particular brand are presented in Table 1. The decision maker had to evaluate the variable costs required to produce the first 12,400 liters of beer and the learning curve percent, enabling to attain the target flat cost in order to define the overall project efficiency.

Table 1

Life cycle parameters of a new beer brand

\begin{tabular}{|l|r|}
\hline \multicolumn{1}{|c|}{ Parameter } & Total value \\
\hline Overall production, l & $12,400.00$ \\
\hline Supply batch size, l & 200.00 \\
\hline Production expenses within the product life cycle: & 14.10 \\
\hline - direct, material expenses, euro/l & 10.25 \\
\hline - variable, operating expenses, euro/l & 28.20 \\
\hline - direct labour expenses, euro/h & 48.60 \\
\hline Time to produce the first batch, h/batch & 80 \\
\hline Learning performance curve, $\%$ & \\
\hline Target indicator: & $334,534.42$ \\
\hline - shared variable costs, euro & \\
\hline
\end{tabular}

In order to calculate the shared variable costs it is necessary to calculate direct labour costs. For this purpose let us define the cumulative meantime necessary to produce one batch using the following formula (1), as a result we gain the following: 


$$
48.6 \times 62^{-0.3219}=12.87 h
$$

Thus, our labour expenses necessary to produce $12,400 \mathrm{l}$ beer will amount to: $12.87 \times 62 \times 28.20=22,501.91$ euro.

The calculation results of the standard manufacturing expenses are presented in Table 2.

Table 2

Evaluation of manufacturing expenses of a new beer brand

\begin{tabular}{|l|l|r|}
\hline \multicolumn{1}{|c|}{ Parameter } & \multicolumn{1}{|c|}{ Calculation } & \multicolumn{1}{c|}{ Total value } \\
\hline Direct expenses: & & $174,840.00$ \\
\hline - material expenses, euro & $12,400.00 \times 14.10$ & $22,501.91$ \\
\hline - labour expenses, euro & - & $127,100.00$ \\
\hline Miscellaneous variable expenses, euro & $12,400.00 \times 10.25$ & $324,441.91$ \\
\hline Manufacturing costs, euro & $174,840+22,501.91+127,100$ & \\
\hline
\end{tabular}

We will define the experience coefficient gained by the personnel, whereby the targeted flat cost is attained using the learning index, calculated as follows from Table 3.

Table 3

Learning index definition

\begin{tabular}{|l|l|r|}
\hline \multicolumn{1}{|c|}{ Parameter } & \multicolumn{1}{c|}{ Calculation } & \multicolumn{1}{c|}{ Total value } \\
\hline Direct labour costs, euro & $334,534.42-301,940.00$ & $32,594.42$ \\
\hline Overall working time, $\mathrm{h}$ & $325,94.42 \div 28.20$ & $1,155.83$ \\
\hline Mean time per batch, h/batch & $1,155.83 \div 62$ & 18.64 \\
\hline Learning index & $\lg (18.64 \div 48.60) \div \lg (62)$ & -0.2322 \\
\hline
\end{tabular}

In accordance with the formula (2) the following equation is valid

$$
\lg V=b \times \lg 2
$$

Or

$$
\lg V=-0.2322 \times \lg 2
$$

from which the learning rate will equal

$$
V=10^{-0.0699}=0.8514 \text { or } 85.1 \% \text {. }
$$

Thus, the percent of the learning curve under which the company will attain the targeted flat value is $85.1 \%$. The cumulative data graph for $85 \%$ learning curve is presented in Fig. 1. 


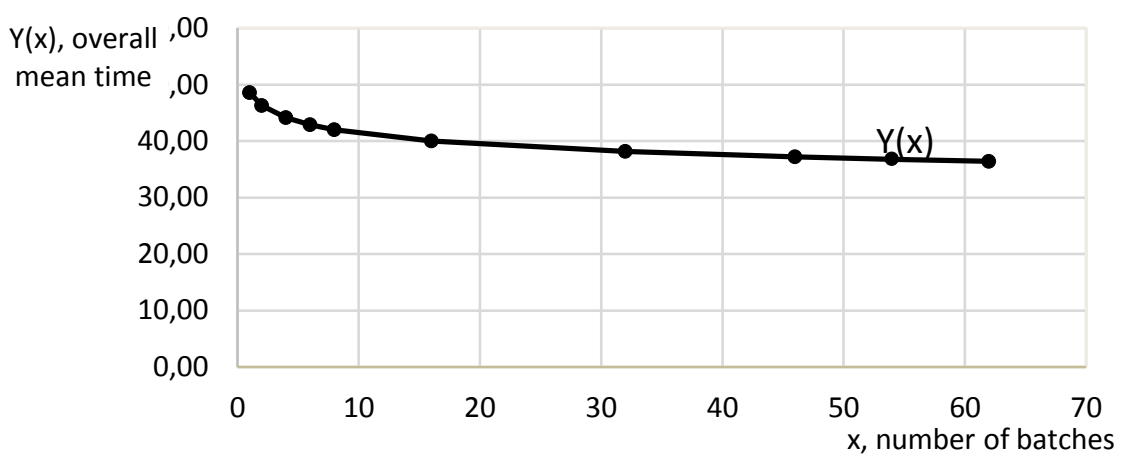

Figure 1 - Graph of $85 \%$ learning curve

It is necessary to note that the learning rate dependence on the working time will be less important with the increase of output.

We believe the knowledge of the learn rate may enhance the efficiency of international trade of a business entity by exerting an influence on the product item price supplied in the framework of international trading agreements, as it represents a rationale for elaborating the pricing value and determining the probable expenses. As it is illustrated by the example to follow, the detailed mechanism of sales price determination of a new beer brand is provided based on both - its life cycle and the learning curve. The characteristics of the product exported are presented in Table 4.

Table 4

Production parameters of export beer brand

\begin{tabular}{|l|r|}
\hline \multicolumn{1}{|c|}{ Parameter } & \multicolumn{1}{c|}{ Total value } \\
\hline Life-cycle of a new beer brand, $\mathrm{I}$ & $11,750.00$ \\
\hline Selling price, euro/l & 48.00 \\
\hline Expenses: & 6.00 \\
\hline - direct labour expenses, euro/h & 16.80 \\
\hline - miscellaneous variable expenses, euro/l & $50,760.00$ \\
\hline - fixed costs, euro & 120.00 \\
\hline Manufacturing time per first batch, h & 125.00 \\
\hline Batch size, l & 80.00 \\
\hline Learning effect, \% & $7,625.00$ \\
\hline Overall production, followed by the rate increase of the learning curve, l & \\
\hline
\end{tabular}

Due to tough competition on the global market a decision maker should evaluate the cumulative time necessary to produce 61 batches and the time used to launch $61^{\text {st }}$ batch before the new beer brand production start-up. The dynamic character of brewery industry and the short life cycle of a new beer brand determine the selling price for the produced 2,350 litres of beer in order to gain profit in the amount equal or higher 282,000 euro. 
Using the formula (1), we will calculate the meantime per batch production for the $61^{\text {st }}$ batch as follows:

$$
120.00 \times 61^{-0.3219}=31.95 \mathrm{~h} / \text { batch }
$$

Using the equation result (3), we will define the overall time necessary to produce $61^{\text {st }}$ batch, which will equal

$$
61 \times 31.95=1,948.95 \mathrm{~h} / \mathrm{batch}
$$

Using the same reasoning as in equations (3) and (4), we will get the mean time used for a batch production is $32.12 \mathrm{~h} / \mathrm{batch}$, provided that the overall output is 60 batches.

$$
120.00 \times 60^{-0.3219}=32.12 \mathrm{~h} / \mathrm{batch}
$$

In this case the overall time necessary to produce 60 batches equals

$$
60 \times 32.12=1,927.20 \mathrm{~h} / \mathrm{batch}
$$

Therefore, the $61^{\text {st }}$ batch will require $21.75 \mathrm{~h}$.

Every batch produced after the output of 7,625 litres of beer, will require the same amount of time as the $61^{\text {st }}$ batch, then the overall time necessary for the output of 11,750 litres will be as follows:

$$
1,948.95+(33 \times 21.75)=2,666.7 h
$$

Thus, the overall labour costs will be as follows:

$$
6.00 \times 2,666.70=16,000.20 \text { euro }
$$

\begin{tabular}{|c|c|c|}
\hline Parameter & Calculation & Total value \\
\hline Revenue from sales, euro & $9,400.00 \times 48.00$ & $451,200.00$ \\
\hline \multicolumn{3}{|l|}{ Expenses: } \\
\hline - direct labour expenses, euro & - & $16,000.20$ \\
\hline $\begin{array}{l}\text { - miscellaneous variable expences, } \\
\text { euro }\end{array}$ & $11,750.00 \times 16.80$ & $197,400.00$ \\
\hline - fixed costs, euro & - & $50,760.00$ \\
\hline $\begin{array}{l}\text { Profit excluding revenue from sales, } \\
\text { euro }\end{array}$ & $\begin{array}{r}451,200-16,200.2-197,400 \\
-50,760 \\
\end{array}$ & $187,039.80$ \\
\hline Target profit, euro & - & $282,000.00$ \\
\hline Expected revenue from sales, euro & $282,000.00-187,039.80$ & $94,960.20$ \\
\hline $\begin{array}{l}\text { Mean selling price essential for attain- } \\
\text { ing a target profit indicator, euro/l }\end{array}$ & $94,960.20 \div 2,350$ & 40.41 \\
\hline
\end{tabular}

Using the result of equation (5), we will calculate the mean sales price of the produced 2, 350 liters of beer which will ensure a company's profit in the amount 282,000 euro (Table 6).

Table 6

Beer sales price evaluation, ensuring the target indicator of profit 
Thus, the conducted calculations show that the learning curve, even though illustrating the production time reduction per unit, doesn't indicate reduction in cost as such. However, if the employees are paid by hour, and the hourly wage is fixed, then the labour costs per unit will reduce due to the learning curve, which in turn will enable the business entity to enhance its performance efficiency on the global market.

In our reckoning, the final evaluation of international trade efficiency is defined by the criterion selected by a decision maker to facilitate operation. However, the merchandise transactions occurring in the international trade environment may be modelled, in order to obtain certain results by means of mathematical methods. One of probabilistic models are the Markovian processes, which can be used when analysing the efficiency of export and import transactions. As it is illustrated by the example to follow, the mechanism of the learning curve defined by an international trading entity in many ways depends on the global market condition.

Despite the dynamic character of the brewery business, this segment of international trade may find itself in one of mutually excluding conditions:

$s_{1}$ - the market with the buyers over will enable the exporter gain a competitive advantage on condition of a $90 \%$ learning curve;

$s_{2}$ - equilibrium market when the quantity demanded equals the quantity supplied, enables the exporter to apply an $80 \%$ learning curve;

$s_{3}$ - market with the sellers over will enable the exporter to carry out transactions on the level of a 70\% learning curve.

The informational data obtained by a decision maker proved that the state of the brewery upmarket in the future will depend on its condition at present. Thus, it has been defined that the market may randomly transfer from one condition to another at any time moment. Variability of transition probability density is feeble within the period under study and can be defined as the following matrix:

$$
\omega=\left(\begin{array}{lll}
0 & 2 & 4 \\
3 & 0 & 1 \\
5 & 1 & 0
\end{array}\right)
$$


In order to prepare a fee proposal on the new upmarket beer brand in order to make an export agreement the decision maker made a mid-term prognosis on the condition of the international beer market. This was aimed to define the time per batch which would facilitate the exporter gain a competitive advantage though the learning curve model.

From the conditions we see that in system $S$ viewed by a decision maker as the international brewery upmarket, there is a discrete homogeneous random process with a continuous time variable, therefore, a random process occurring in system $S$ may be considered a Markovian process characterized by the absence of aftereffect. The process is discrete due to the fact that a set of states of the analyzed system $S$ is finite $\left\{s_{1}, s_{2}, s_{3}\right\}$. Since the transition of system $S$ from one condition to another may occur at any random moment of time, then it can be qualified as continuous-time Markovian process.

The analysis of the discrete Markovian processes occurring in system $S$ should be carried out using the state graph compiled based on the density matrix of transition probabilities (6), which is shown in Fig.2.

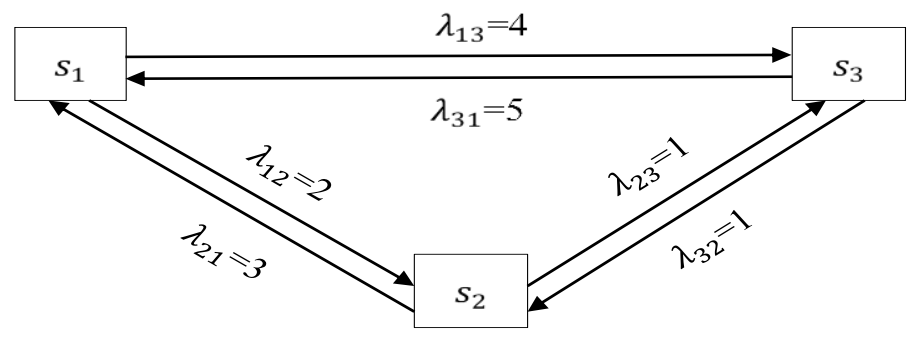

Figure 2 - Marked state graph of the international brewery market

The analysis of the graph shows that system $S$ is ergodic, since any of its implementations features the same characteristic features and one implementation of sufficient duration, when processing may replace the numerous implementations featuring the same total duration [6, PP 458-459]. Thus, system $S$ may pass from state $s_{1}$ to any other using the following path (Fig. 3).

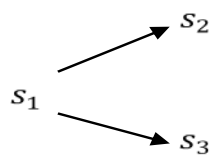

Figure 3 - Ergodic system

Some researchers [2, P 115] provided evidence that there are final probabilities of the states, on condition that the number of system $S$ states is finite, system $S$ is ergodic and all the flows of events generating the transitions of system $S$ from one state to another are elementary. Since system $S$ meets all the above 
mentioned conditions, there are final probabilities of its state $p_{1}, p_{2}, p_{3}$, independent on the time or initial state of system $S$. These final probabilities contain information on mid-term prognosis of the condition of international brewery upmarket.

We will make up $n=3$ algebraic linear equations relative of three variables: $p_{1}, p_{2}, p_{3}$.

$$
\left\{\begin{array}{c}
-6 p_{1}+3 p_{2}+5 p_{3}=0 \\
2 p_{1}-4 p_{2}+p_{3}=0 \\
4 p_{1}+p_{2}-6 p_{3}=0
\end{array}\right.
$$

And carry out a number of transformations in the system (7). This way we will get the following:

$$
\left\{\begin{array}{c}
-6 p_{1}+3 p_{2}+5 p_{3}=0 \\
18 p_{1}-23 p_{3}=0 \\
p_{2}=6 p_{3}-4 p_{1} .
\end{array}\right.
$$

Where

$$
\left\{\begin{array}{c}
-6 p_{1}+3 p_{2}+5 p_{3}=0 \\
p_{1}=1.2778 p_{3} \\
p_{2}=6 p_{3}-4 p_{1} .
\end{array}\right.
$$

If we place expression for $p_{1}$ into the third equation of a system (8), we will get $p_{2}$ :

$$
\left\{\begin{array}{c}
-6 p_{1}+3 p_{2}+5 p_{3}=0 \\
p_{1}=1.2778 p_{3} \\
p_{2}=0.8888 p_{3} .
\end{array}\right.
$$

Therefore, the general solution of the system (7), depending on one arbitrary parameter $p_{3} \in[0.1]$ and representing a set of specific solutions has the following view:

$$
\left(p_{1}=1.2778 p_{3} ; p_{2}=0.8888 p_{3} ; p_{3}\right)
$$

With reference to specific solutions (9), it is necessary to find the one, which would meet the normalizing condition:

$$
p_{1}+p_{2}+p_{3}=1
$$

By substituting into expression (10) values $p_{1}, p_{2}$ found above we will get the following equation: 
$1.2778 p_{3}+0.8888 p_{3}+p_{3}=1$. where

$p_{3}=0.3158$.

then

$p_{1}=1.2778 p_{3}=1.2778 \times 0.3158=0.4035$;

$p_{2}=0.8888 p_{3}=0.8888 \times 0.3158=0.2807$.

Thus, the mid-term prognosis of the state of international brewery upmarket is that upon the expiry of the period of one to two years it is very likely that (p_1 $=0.4035>p_{-} 2$, $p_{-} 3$ ) the market will be in overproduction state, when the supply exceeds demand. Therefore in order to gain competitive advantages on the global market the exporter has to carry out transactions aimed at the production of a new beer brand with a $90 \%$ learning curve.

Upon systematization of research outcomes we may draw the following conclusions:

1.A learning curve makes it possible to establish optimal pricing proposals for foreign contracting parties. The analysis of this curve allows revealing losses that may be incurred by a company when implementing an international trading agreement under economic uncertainty.

2.A learning curve, inherently representing a rationale for expenditures monitoring, is an essential tool for new product pricing, which strengthens the competitive position of a business entity on the global market, and eventually enhances efficiency of its activity in the international trade.

3.In order to define probabilistic functions of the learning curve at a particular moment, is it recommended to use Kolmogorov's system of differential equations, compiled based on the marked graph of states or the density matrix of transition probabilities.

The effect of learning is necessary for attaining the expected production level, as it results in a decrease of direct work time costs and overheads, which vary depending on work hours. Eventually it enhances the efficiency of international trade of a business entity regardless of conditions under which the production level is defined exclusively by the work of automated systems.

\section{References}

[1] Chartered Institute of Management Accountants [Electronic resource]: official site. Access mode: http://www.cimaglobal.com/Research--Insight/

[2] Labsker L.G. Probabilistic modelling in the financial-economic field [Text]: the Textbook / L.G. Labsker. The second edition. M: INFRA-M, 2014. pp. 172.

[3] Martyanova O.V. Modeling efficiency business activities in the conditions of uncertainty on the basis of a curve training and assessment of final probabilities of its conditions [Text] / O. V. Martyanova //Audit and a financial analysis. 2016. № 1. P. 98110.

[4] Release of beer in Russia began to be reduced even to crisis approach [Electronic resource]. URL: http://e-malt.ru/News.asp?Command=ArticleShow\&ArticleID=3628

[5] Vasilchuk O. I. Bases of providing competitiveness of the entities of service trade 
[Text] / O. I. Vasilchuk//News of Academy of management: theory, strategy, innovations. 2011. № 5 P. 12-16.

[6] Venttsel E. S. Probability theory [Text] / E.S. Venttsel. Third edition. M.: Soviet Radio publishing house, $1964.560 \mathrm{p}$. 


\title{
FEATURES OF THE TAXATION OF REAL ESTATE INDIVIDUALS IN THE USA
}

\author{
Yu. $\operatorname{Lvov}^{1}$
}

\section{Abstract}

In article urgent mechanisms of the taxation of property of citizens of the USA which are actively used when developing the bills of the domestic right adapted to a current financial economic state of subjects of the taxation are analyzed. The author marks out features of calculation of a tax, division of tax masses according to categories, features of providing preferential categories which considers in this article.

Keywords: taxation of individuals, the United States, property taxation, local taxation, tax incentives, tax rates.

Индексация налога на недвижимость исходящая из ее кадастровой стоимости, имеет положительную практику применения во многих странах мира, как с хорошо развитой рыночной, так и с переходной экономикой, зарекомендовав себя действенным регулятором выполнения фискальной, стимулирующей и социальной функций. В США в зависимости от штата эта доля составляет от 10 до 70\%. Из этого автор делает вывод, что при последовательном адаптировании концептуальных приемов, эта система может быть успешно применена в Российской Федерации [1].

Следует отметить законодательную и практическую новизну для России в налогообложении недвижимости. Целесообразно обратить внимание на сформировавшийся в зарубежных странах практический опыт, элементы механизмов которого, могут послужить основополагающей частью комплексных механизмов взимания налога на недвижимость, для внедрения в РФ.

Говоря о налогообложении недвижимости в США, следует отметить что данное понятие неотделимо от структуры поимущественного налогообложения, которое является наиболее значимым из всех местных налогов. Он совсем не взимается на федеральном уровне и является подведомственным исключительно для органов МСУ. В 1920 году данный налог, взимался на уровне штатов, представляя собой наиболее важный источник доходов для бюджетов, однако к 1950 году его роль значительно уменьшилась относительно доходной части бюджетов штатов и увеличилась для органов местной власти. На данный момент поимущественный налог является прямой демонстрацией воплощения принципа разделения налоговых доходов в бюджеты МСУ и штатов. Фактически, данный налог включает в себя множество отдельных налогов, так как большинство территорий, на которых он взимается, обладают правом вводить собственные налоги на имущество.

\footnotetext{
1Yuri Lvov, graduate of the Faculty of Law, branch of MGIMO, (Odintsovo), Russia.
} 
В середине восьмидесятых годов данный налог обеспечил поступление в местные бюджеты более 85 миллиардов долларов, в начале девяностых, эта сумма составляла свыше 160 миллиардов долларов, т.е. в 2 раза больше. К 2016 году на долю поимущественного налога в среднем приходилось около 40\% общих доходов или до $80 \%$ налоговых доходов бюджетов органов МСУ.

Начиная с 1956 года, в Соединенных Штатах Америки учреждён специальный Земельный банк, к ведомству которого отнесено предоставление кредитов на развитие сельского хозяйства фермеров, в том числе и на льготных условиях, для тех фермеров, которые не увеличивают или сокращают возделываемую площадь своих земельных участков.

Имущественные налоги в США приносят сегодня до $80 \%$ всех поступлений в местные бюджеты, $30 \%$ которых составляют налоги взимаемые с недвижимости физических лиц [2]. Разделяют следующие виды объектов налогообложения имущества в США (табл. 1)

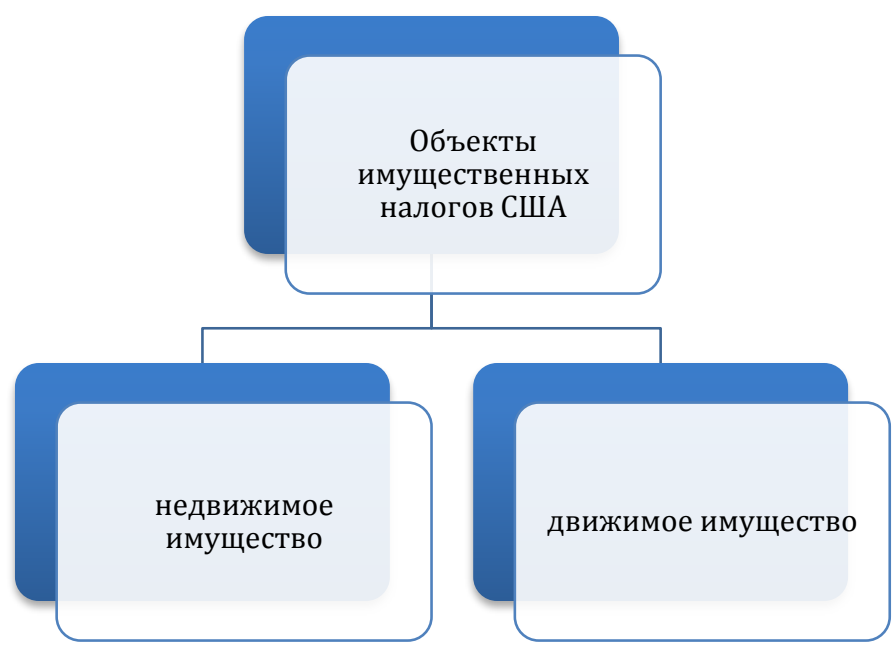

(Таблица 1)

Основным местным налогом в США является налог на недвижимость. В Америке и Канаде за счет средств, поступающих от взимания налога на недвижимость, местными органами власти финансируются вся социальная система содержащая на обеспечении полицию, школы, службы пожарной охраны, систему здравоохранения.

Местный налог (The Property Tax) на недвижимость в США, регулируется на уровне графства (The County), выделяя объектом налога земельноимущественный комплекс в форме участка и строений на нем. Каждый год проводится переоценка недвижимости, которая основывается на рыночной цене, данный механизм обеспечивает максимальную точность в исчислении процента из кадастровой оценки. Автор отмечает, что данный меха- 
низм, при адаптации к отечественному праву, будет способствовать минимизации объема судебных процессов по занижению кадастровой оценки недвижимости, которая на данный момент резко отличается от рыночной и чаще резко завышена.

Всю ценовую информацию можно получить на местном уровне, которые регистрируются в графстве. Объекты переоценки (земельный участок и строения на нем) оцениваются раздельно. В США налог на недвижимость уплачивается двумя равными долями в течение года, а уплаченная сумма принимается к зачету при расчете налоговой базы подоходного налога с физических лиц.

Американское законодательство предусматривает действенные механизмы по предотвращению уклонения от своевременной уплаты налогов, предлагая следующие меры [3]:

- увеличение налоговой базы, не повышая размер налоговой ставки, путем плановых переоценок;

- повышение ставки до 1,0\%, только если дополнительная сумма доходов направляется на погашение долгов МСУ.

- установление льгот, особым категориям в форме освобождения от уплаты налога (Таблица 2)
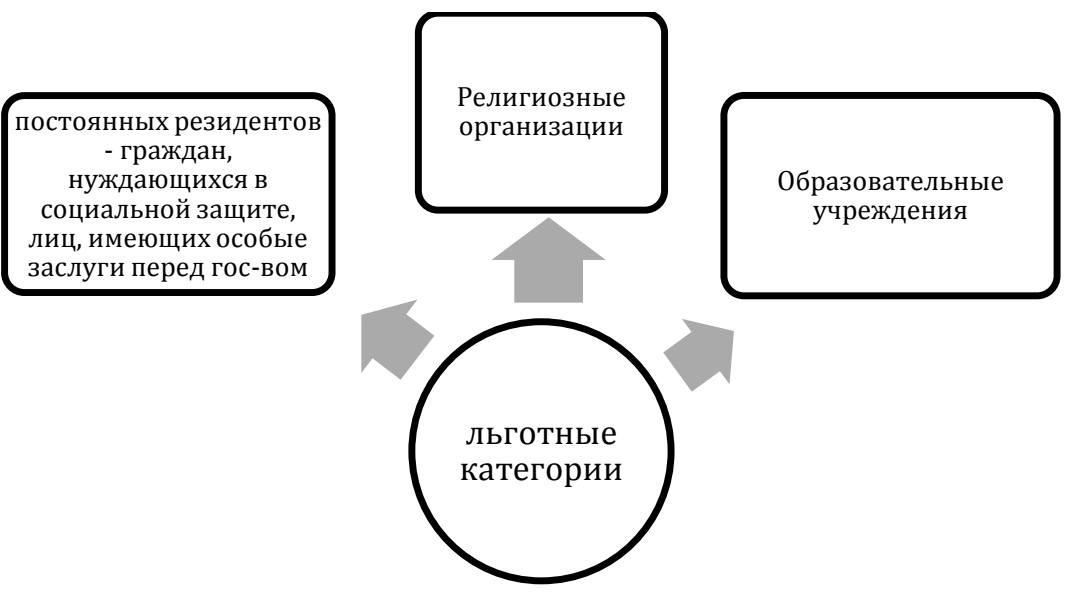

Так в городе Нью-Йорк, налог взимается со всех объектов, за исключением, льготных категорий упомянутых ранее на основании права. Данный налог, формирует почти половину бюджета города (40\%).

Городской совет Нью-Йорка (New York City Council) является законодательным органом правительства, которому подведомственны вопросы землепользования, а также утверждение городского бюджета, ежегодно утверждает размер ставок налога на недвижимость для каждого налогового класса. Для оптимизации налогообложения, по признаку однотипных строений, город был разделен на пять административных округов, каждому из которых, Департаментом финансов была присвоена категория и налоговый класс. 
Налоговые ставки города Нью-Йорк

Таблица 3

Налоговая ставка на каждые 100 \$ нал.базы

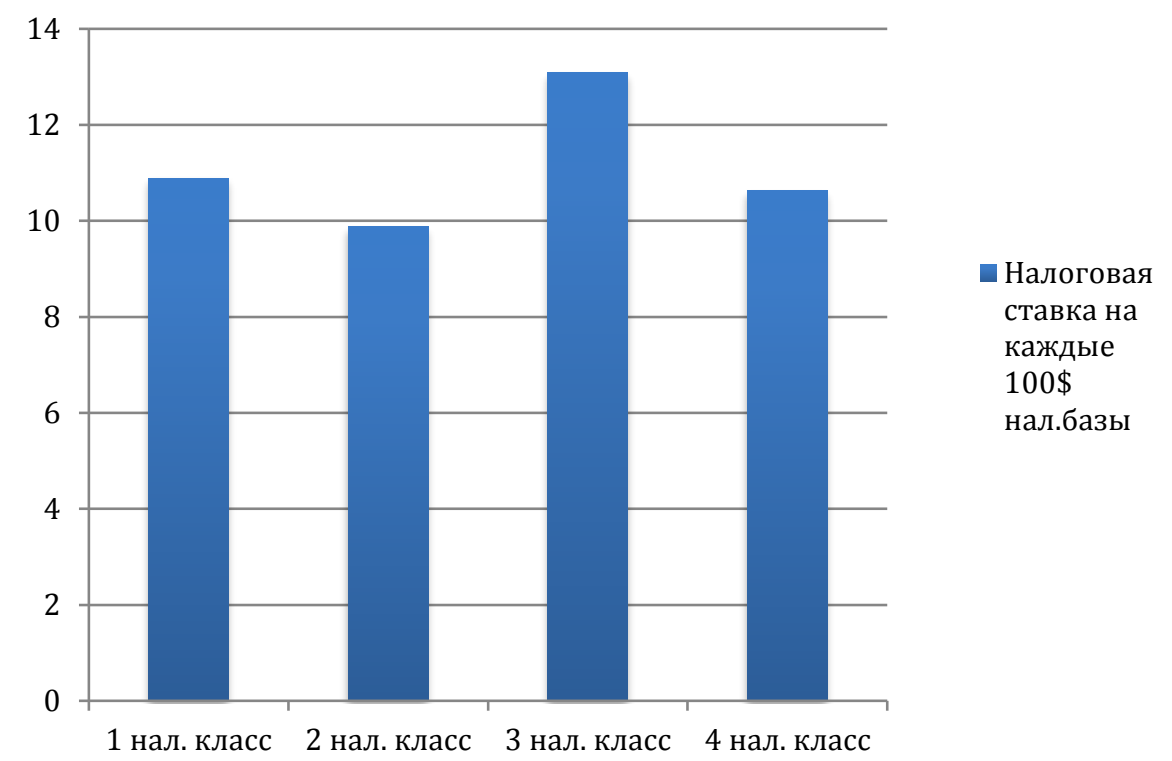

Разделение объектов недвижимости по указанным четырем налоговым классам может быть представлено в виде следующей таблицы.

Таблица 4

Классификационное деление недвижимого имущества [6]

\begin{tabular}{|c|l|}
\hline $\begin{array}{l}\text { Налоговый } \\
\text { класс }\end{array}$ & Категория недвижимости \\
\hline 1 & $\begin{array}{l}\text { Жилые дома до 3-х семей } \\
\text { Новопостроенные кондоминиумы до 3-х этажей, } \\
\text { также определенные виды свободных земель в зонах } \\
\text { жилой застройки }\end{array}$ \\
\hline 1 в & $\begin{array}{l}\text { Все другие виды жилой недвижимости, не подпадаю- } \\
\text { щие под 1-класс }\end{array}$ \\
\hline 2 & Оборудование коммунальных компаний \\
\hline 4 & $\begin{array}{l}\text { Иные, включая коммерческие строения, здания и зе- } \\
\text { мельные участки коммунальных компаний; свобод- } \\
\text { ные земельные участки,не подпадающие под 1-класс }\end{array}$ \\
\hline
\end{tabular}

При оценке недвижимости учитывается ее рыночная стоимость, однако налоговая база представляет собой часть рыночной цены в соответствии с законом штата. Порядок и срок уплаты налога определяется исходя из результатов оценки. Так, если сумма не превышает 40 тысяч долларов США, налог уплачивается в течение финансового года поквартально не позднее 
первого числа июля, октября, января и апреля.

При превышении стоимости недвижимости в 40 тысяч долларов США, налог подлежит уплате двумя равными долями по полугодиям не позднее первого июля и января. Погашая ипотечный кредит, меняя почтовый адрес, приобретая недвижимость, налогоплательщик обязан в каждый налоговый период высылать в регистрационный орган города специальную регистрационную карточку собственника с обновленными данными.

Законодательство предусматривает радикальные меры за уклонение от уплаты налога в виде изъятия недвижимости из собственности налогоплательщика. Изъятие происходит при проведении так называемой «іn rem» процедуры. По окончании которой, новым собственником становится город.

Категория недвижимости определяет период времени непогашенной задолженности, по истечению которого департамент финансов может начинать процедуру изъятия имущества.

Таблица 5

Категории периодов

\begin{tabular}{|c|c|}
\hline 3 года & $\begin{array}{c}\text { Жилые дома и кондоминиумы (1-2семьи) при ежегодной сумме } \\
\text { налогов не превышающей } 2750 \$\end{array}$ \\
\hline 1 год & Иная недвижимость \\
\hline
\end{tabular}

Таким образом, формирование налоговой массы и ее оборот происходит на уровне графств штата, формируя бюджеты муниципалитетов, графств и налоговых округов. В соответствии с законодательством из кадастровой стоимости могут отчуждаться вычеты, предусмотренные органом оценки графства, формируя итоговую налогооблагаемую массу. Данный механизм схож с субсидиарной системой в РФ, функциями которой является снижение налоговой нагрузки на малообеспеченные слои населения.

Законодательно различают следующие виды недвижимости: дома на одну и более семей, городские квартиры, кондоминиумы, свободные земли, промышленная и сельскохозяйственная недвижимость, свободная и застроенная. Не позднее 1 июля каждого года, органы графств приступают к оценке имущества находящегося на территории и официально обнародуют данные результаты. При оценке учитывается текущая стоимость объекта, местонахождение и площадь, способ использования, степень изношенности дома или усталость земли, дивиденды, поступающие от использования или доход от продажи объекта. Не позднее 1 ноября текущего года, рассылаются уведомления налогоплательщикам, которые должны быть погашены до 1 апреля следующего года. За досрочную уплату, законодательство предусматривает скидку, вычитаемую из суммы налога (-4\%), также предусмотрены пени за несвоевременное погашение задолженности (18\%) годовых, при минимальных 3\% суммы налога. В соответствии с Конституцией, принимаемой штатом, на уровне каждого графства избираются профессиональные оценщики, которые остаются закреплены за этим штатом. В случае несогласия собственника с оценкой 
имущества, ему предоставляется право подачи апелляции в уполномоченный орган по разрешению оспаривании об оценке (Value Adjustment Board - VAB).

Для получения налоговых вычетов, необходимо подать запрос в орган графства, занимающийся оценкой имущества - (County Property Appraisers Office), данный орган занимается разъяснением прав граждан относительно предоставляемых льгот по уплате налогов, информирует о документах и формах необходимых для оформления налоговых привилегий. Законом установлен период с первого января по первое марта текущего года для регистрации налогового вычета. Рассмотрим налоговые вычеты на примере штата Флорида применяемые в отношении объектов недвижимого имущества [4].

\begin{tabular}{|l|l|}
\hline 1 & Установлен необлагаемый минимум для жилых домов до 25000 \$ \\
\hline 2 & $\begin{array}{l}\text { Вдовий налоговый вычет - } 500 \text { \$ (утрачивается при заключении } \\
\text { брака) }\end{array}$ \\
\hline 3 & По постоянной инвалидности - 500 \$ \\
\hline 4 & Для слепых граждан - 500 \$ \\
\hline 5 & $\begin{array}{l}\text { Ветераны войны с постоянной инвалидностью и парализованные } \\
\text { граждане полностью освобождаются от уплаты налога. }\end{array}$ \\
\hline
\end{tabular}

Автор отмечает, что в большинстве стран мира налог на недвижимость только обретает свою значимость для бюджета на всех уровнях власти, поступления от которого составляют от 1-3\%, в США эта цифра близка к 9\%. Мировой опыт показывает, что финансово-экономическую свободу местного самоуправления обеспечивает налог на недвижимость (поимущественный в США)

Таким образом, облагается налогом вся собственность за исключением наличных денег. В зависимости от штата будут различны объекты налогообложения, так в четырех штатах налог взимается только с недвижимости, в иных штатах налог будет взиматься и за движимое имущество включая личный транспорт и товарные запасы, а также и за недвижимое имущество к которому в соответствии с американским законодательством отнесены акции, ценные бумаги, ипотеки, договоры. Исключение будут составлять (tax exempt security), принадлежащие штатам муниципальные облигации, которые освобождены от налогообложения в силу закона. Что касается зависимости штатов от данного местного налога, она достаточно велика, так как обеспечивает всю социальную систему штата, в особенности школьные районы. Эффективность налога, вытекает из привязанности объектов налогообложения к месту, то есть недвижимость останется в этом районе, даже при увеличении налоговых ставок или налоговой базы. Сейчас базой для расчёта суммы налога является рыночная (инвентаризационная) стоимость, которая учитывает естественный износ, индексирует рост или снижение цен на строительную продукцию, работы, услуги. Поскольку об- 
ложение и изъятие этого налога происходят согласно местному законодательству, то ставки налога различаются и устанавливаются как в процентом отношении от стоимости имущества, так и в виде твердой суммы с единицы стоимости имущества.

Для устранения частых колебаний зависимых от рынка, применяются особые коэффициенты. Имея прямую зависимость отношения доходов к расходам, ставки поимущественного дохода в США исчисляются как частное от деления суммы доходов, которая должна быть получена от поимущественного налога, на стоимость облагаемого имущества [5]. В независимости от доходности и размеров собственности налогооблагаемой единицы, применима единая ставка. Сорок два штата установили верхний придел ставки, но являясь основным доходом местного бюджета, он зачастую изымается и в бюджеты штатов. Не является возможным реализация социальных программ на местном уровне без существования самостоятельной налоговой системы, основу которой составляет поимущественное налогообложение, отдавая особенную роль налогообложению недвижимости.

References:

[1] Налоговые системы зарубежных стран: учебник / Н.Н. Тютюрюков. -учеб. изд. М.: ИТК «Дашков и К» 2009. -176 с.

[2] Л.Н. Лыкова И. С. Букина «Налоговые системы зарубежных стран» -учеб. изд. -М. Юрайт. 2016 с 150.

[3] Соловьева Н.А. Карасева М.В «Налоговые вычеты и налоговые льготы Проблемы соотношения и законодательного закрепления США»- Москва. 2016 с 46.

[4] Library of Congress https://www.loc.gov/rr/frd/Military_Law/Lieber_Collection/pdf/Essays-on-Property-Labour.pdf

[5] Library of Congress https://www.congress.gov/bill/112th-congress/house-resolution/557 H.Res.557 Expressing the sense of the House of Representatives that the current property tax deduction on private residences should not be further restricted. 112th Congress (2011-2012) 


\title{
SOCIAL PROTECTION AS A DEVELOPING SOCIAL INSTITUTION
}

\author{
S. Kasymova ${ }^{1}$
}

\section{Abstract}

In this article, social protection is considered as a function of the society to ensure the social status of its members corresponding to the conditions arising from the inherent and widely recognized social human rights and the improvement of current due to exposure to social risk position. After all, the objective feature of any society is social inequality, which is characterized by unequal access of citizens to socially significant goods, such as money, power, education, prestige.

Keywords: Social protection, the standard, targeting, life support, human rights, to provide for the family.

Социальная защита населения является неотъемлемой частью социальной политики любого государства и играет исключительно важную роль в обществе. Она имеет свою систему категорий, терминов, понятий, характеризующих совокупность правовых норм, регулирующих вопросы решения определенных социальных проблем.

Социальная защита обычно имеет дело с установленными законодательством категориями граждан, которые в силу утраты трудоспособности, отсутствия работы, либо по другим причинам не имеют достаточных средств для удовлетворения своих жизненно важных потребностей и потребностей нетрудоспособных членов своей семьи.

Как отмечает в своих трудах Е.И. Холостова, социальная защита - функция общества по обеспечению социального положения его членов, соответствующего условиям, вытекающим из неотъемлемых и общепризнанных социальных прав человека (получение средств к существованию, наличие работы, доступность образования и медицинского обслуживания, наличие жилья и др.), а также улучшение сложившегося вследствие воздействия социальных рисков положения [1].

В рамках системы социальной защиты таким гражданам при наступлении установленных законодательством неблагоприятных событий предоставляется помощь компенсационного характера в денежной и натуральной форме, а также в форме различного рода услуг. Кроме того, системы социальной защиты осуществляют меры профилактического характера, направленные на предотвращение неблагоприятных событий.

Структурно-функциональный анализ системы социальной защиты следует начать с ее роли в общей схеме социальной политики.

${ }^{1}$ Suita Kasymova, Graduate student of the Osh Technological University Academician M. Adysheva, Kyrgyzstan. 
Приоритетом социальной политики выступает социальное государство, цель которого это создание условий, обеспечивающих достойную жизнь и свободное развитие человека.

Социальная защита населения в широком смысле слова - это совокупность социально-экономических мероприятий, проводимых государством и обществом и обеспечивающих предоставление оптимальных условий жизни, удовлетворение потребностей, поддержание жизнеобеспечения и деятельного существования личности и социальной группы, совокупность мер, преодолевающих последствия ситуаций риска в жизни граждан, комплекс мер по обеспечению гарантированного государством минимального уровня материальной поддержки социально уязвимых слоев населения в период экономических преобразований и связанного с этим снижения уровня жизни [2].

Это функция государства и общества по обеспечению человека потенциальными жизненными благами, в соответствии с его неотъемлемыми и целесообразными, с позиции развития личности, социальными правами на труд, на социальное и материальное обеспечение семьи, на жизненный уровень, необходимый для поддержания его здоровья и благосостояния и т.д. Следовательно, она определяется как предмет идеологии и социальной политики государства и область его практической деятельности.

Ведь объективной чертой любого общества является социальное неравенство, которое характеризуется неодинаковым доступом граждан к социально значимым благам, таким как деньги, власть, образование, престиж. Государство должно вести поиск оптимального уровня, регулировать неравенство, разрабатывая и применяя специальные механизмы. Таким путем в системе социальной защиты можно устранять и минимизировать влияние тех причин социального неравенства, которые оцениваются как несправедливые. [3]

В соответствии с Конституцией Кыргызской Республики, Кыргызская Республика признает одним из высших ценностей право человека на социальную защиту и проводит политику, направленную на утверждение в обществе социальной справедливости. Правительство Кыргызской Республики обеспечивает преемственность ценностей и принципов социальной справедливости, заложенных в Стратегии на 2012-2014 годы. В связи с этим Программа на 2015-2017 годы также нацелена на оказание адресной социальной помощи наиболее уязвимым категориям граждан, стимулирование экономической активности трудоспособного населения и оказание содействия в выходе из трудной жизненной ситуации. Задачи обеспечения минимального уровня материального благополучия нуждающихся граждан, которые были определены в Стратегии_на 2012-2014 годы, остаются приоритетами государства в Программе на 2015-2017 годы. При обеспечении социальной защиты населения государство будет придерживаться тех же принципов, что и в Стратегии на 2012-2014 годы: ценность семьи; адресность, адекватность и достаточность мер социальной защиты, отвечающих минимальным потребностям получателей; прозрачность; гаранти- 
рованность и доступность; комплексность социальных услуг и возможность их выбора; обеспечение равных возможностей и доступа к социальным услугам и благам всех лиц независимо от социального, имущественного, возрастного, этнического, полового и других статусов; ответственность органов государственной власти и местного самоуправления.

Кыргызстан признает международные соглашения в сфере социальной защиты и допускает, что субъектом социальной защиты являются не только государственные органы и органы местного самоуправления, но также бизнес, неправительственные организации и международные партнеры по развитию при координирующей роли государства [4].

Позитивными факторами для реализации Программы на 2015-2017 годы является совершенствование законодательства в сфере социальной защиты населения, активное участие некоммерческих организаций в оказании социальных услуг на местном уровне. Значимым фактором являются понимание важности доступа и развития социальных услуг для населения, повышения эффективности взаимодействия и координации между государственными органами, неправительственным сектором и международными организациями.

Развивающийся потенциал гражданского общества, активно использующего международный опыт и инновационные подходы в сфере социальной защиты, также является позитивным фактором для реализации Программы на 2015-2017 годы. К положительным аспектам относятся также успешное сотрудничество и возможность дальнейшей технической поддержки со стороны международных институтов, с помощью которых возможно улучшить систему социальной защиты, используя международный опыт. Вместе с тем, наряду с положительными предпосылками, существуют факторы, которые могут препятствовать реализации Программы на 2015-2017 годы. К ним относятся: нехватка финансовых средств в бюджете республики, недостаточный уровень кадрового потенциала государственных органов и органов местного самоуправления, отток и частая сменяемость кадров.

Основная цель развития сферы социальных услуг в ближайшей перспективе направлена на адресность получателей, создание эффективной системы социальной защиты населения, повышение качества человеческих ресурсов, обеспечение доступа к качественным социальным услугам, особенно бедных и социально уязвимых слоев населения. В новых условиях сфера социальных услуг указанной цели может достичь при реформировании и реорганизации ее отраслей, их подчинения задачам, которые возникают на данном этапе экономического и социального развития. Данной сфере необходимы глубокие реформы, которые должны начаться незамедлительно в отраслях сферы социальных услуг. Не маловажную роль в реформировании социальных услуг является повышение подотчетности, прозрачности работы государственных и муниципальных органов власти, предоставляющие данные услуги, то есть добросовестное управление в сфере предоставлении социальных услуг.

Потребность граждан в государственной социальной защите может 
быть обусловлена следующими обстоятельствами:

-полной, частичной, временной или постоянной потерей трудоспособности из-за болезни или по возрасту;

-потерей кормильца, наличием многодетной или неполной семьи, уходом за детьми-инвалидами и прочими факторами личного характера;

-изменениями в социально-политической, экономической, международной обстановке (спад производства, рост инфляции, банкротств, безработицы и т.п.);

-неблагоприятными климатическими, природными и стихийными явлениями катастрофического и продолжительного характера.

Социальная защита населения является одним из важнейших звеньев в системе социального управления обществом. Вместе с тем она оказывает влияние на общее самочувствие общества и происходящие в нем экономические и политические процессы.

Концепция социальной защиты населения должна опираться на идею о том, что система социальной защиты является одной из главных составляющих процесса воспроизводства, не только населения, но и всего экономического потенциала страны.

\section{References:}

[1] Холостова Е.И. Социальная работа: учебник. М., 2012.

[2] Савинов А.Н. Организация работы органов социального обеспечения. М., 2003.

[3] Теория социальной работы / под общ. ред. Кузиной И.Г. Владивосток, 2006.

[4] Программа развития социальной защиты населения Кыргызской Республики на 2015-2017 годы.

[5] Теория и практика социальной работы в Кыргызстане. Бишкек: БГУ. 2005. 


\title{
INTERACTION OF FINANCE, CREDIT AND REAL SECTOR OF ECONOMICS
}

\author{
V. Koreshkov' ${ }^{1}$ I. Makelko ${ }^{2}$
}

\section{Abstract}

The article discusses the relationship of finance and credit, provides a refined definition of finance offered to support the real sector of economy measures, through the tools of regional commercial banks and local authorities.

Keywords: Credit, Commercial Bank, small and medium businesses.

Успешное развитие современной экономики РФ во многом зависит от стабильного развития реального сектора экономики, насыщения рынка разнообразными видами товаров и услуг, формирование здоровой конкуренции, создание новых рабочих мест. В развитии экономического хозяйства, помимо основных институтов власти, с развитием рыночной экономики страны важную роль играют кредитные организации.

В настоящее время, одним из негативных факторов развития реального сектора экономики является проблема ограниченного предложения доступных финансовых ресурсов. Существуют также проблемы с доступностью краткосрочных кредитных средств, для обеспечения текущих финансовых потребностей бизнеса.

Экономика РФ в условиях экономических санкций, ориентирована на внутренние ресурсы, а значит, от их доступности и качества зависит стабильность дальнейшего экономического развития общества.

Далее рассмотрим выделенные категории и их взаимосвязь, так по мнению Г.Б. Поляка, финансы - это звено денежной сферы, в которой обеспечение потребностей субъектов общественного воспроизводства осуществляется путем аккумуляции денежных средств; финансы - форма одностороннего дискретного движения денег [1, с. 37].

Становление финансовой формы движения денег имеет для экономической системы важное следствие. Прерывные движения финансовых ресурсов предполагает определенную «временную свободу» денежных средств от движения к «своему» товару- накопления всегда требуют определенного времени. Общественные потребности в деньгах такого рода «временные потребности» незамедлительно превращаю свободные денежные средства в источник своего обеспечения.

Для экономической системы денежные средства, временно свободные от своего целевого значения, - это дополнительные ресурсы, которые включаются системой в решение задач, расширяя материальную базу де-

1Vladislav Koreshkov, Lecturer of Economic Sciences, Finance and Credit, Altai State Technical University, Russia.

2Irina Makelko, magistrant of Economic Sciences, Altai State University, Russia. 
нежной сферы и ускоряя движение денежных потоков. Со временем система практически полностью реализует потенциал свободных средств, организуя их аккумуляцию и превращая в устойчивый источник как своего текущего обеспечения, так и развития. Формируется новое движение денег. Его принципиальной особенностью является двукратный процесс денежного обеспечения. Вместе с тем, финансы в системе экономических отношений имеют строгие экономические границы, позволяющие выделить их из большой совокупности денежных отношений. Денежные отношения по своему содержанию и составу значительно шире финансовых отношений.

Таким образом, финансы - не деньги и не денежные средства сами по себе, а определенные денежные отношения, складывающиеся в распределительном процессе по поводу формирования и использования денежных доходов и накоплений, выраженных в понятии «финансовые ресурсы». Финансы всегда выражают денежные отношения, но не всякие денежные отношения могут быть отнесены к финансовым. Финансы проявляют себя через реальное движение денежных средств, но они не тождественны деньгами.

В свою очередь, ученые определяют деньги, как - лишь основу и необходимое условие существования финансов [2, с. 12]. Наличие общих черт у финансов и кредита предопределяет их тесную взаимосвязь и взаимодействие в распределительном процессе; особенно ярко это проявляется в комплексном использовании финансовых и кредитных ресурсов. При недостатке у предприятий финансовых ресурсов для нормального осуществления производственного процесса и расширения производства, они используют банковские кредиты.

Временно свободные финансовые ресурсы предприятий и хозяйственных организаций хранятся на счетах в учреждениях банков, что позволяет рационально использовать их в качестве кредитных средств для удовлетворения потребностей расширенного воспроизводства в рамках народного хозяйства в целом.

Функционирование финансов способствует созданию и росту кредитных ресурсов; функционирование кредита, в свою очередь, позволяет формировать финансовые ресурсы в распоряжении субъектов хозяйствования и государства, в том числе через финансовый рынок [3].

Финансы и кредит имеют общую экономическую природу - в их основе лежат товарно-денежные отношения [4].

Выделим общие черты данных категорий:

- Участие обеих категорий в формировании различных фондов денежных средств (признак фондообразования);

- Основой являются товарно-денежные отношения;

- Выражают движение стоимости в ее денежной форме;

- Используются в функции средства обращения или средства платежа;

- В кругообороте фондов предприятия нет отличия между собственными и кредитными деньгами.

Проанализировав общие черты, можно сделать вывод о том, что кредит 
наиболее близок к финансовым отношениям.

Таким образом, следует иметь ввиду, что все финансовые отношения в их развитом виде являются денежными, но не все денежные отношения относятся к финансовым [5].

В связи с этим, необходимо уточнить категорию «финансов» в части взаимодействия с категорией «кредит» адекватно современным условиям деятельности предприятий. По нашему мнению, финансы - это денежные отношения между государством с одной стороны, юридическими лицами и финансово-кредитными организациями с другой стороны, возникшие при образовании, распределении и использования денежных потоков, используемых на расширенное производство и удовлетворение различных потребностей предприятия.

Несмотря на существующие различия, выраженная взаимосвязь финансов и кредита проявляется и в банковском проценте, непосредственно связанном с существованием и функционированием кредита и оказывающим непосредственное влияние на доступность кредитных ресурсов для реального сектора экономики.

Совокупность потребностей организаций, особенностей процесса воспроизводства, в том числе денежного обеспечения для сокращения кассовых разрывов для непрерывного существования предприятий, порождает постоянную потребность в кредитных средствах.

В настоящее время, весьма значимой для бизнеса является проблема недостатка финансовых ресурсов, как собственных, так и заемных. По оценкам экспертов лишь малая часть - примерно 30\% от имеющейся потребности в кредитах для малого бизнеса сегодня удовлетворена, а в части микрокредитов (сумм до 300 тыс. рублей), иногда и $10 \%$.

Особенно сложно получить кредит начинающему предпринимателю. Преобладающая часть предпринимателей не пользуется кредитными и заемными средствами прежде всего из-за отсутствия у малых предприятий необходимого обеспечения и кредитной истории.

Другой причиной ограниченного кредитования экономики являются высокие риски, связанные с кредитованием малых предприятий, и накладные расходы банков, которые почти одинаковы как для небольших ссуд, так и для крупных.

Вместе с тем, говоря об общих тенденциях развития сектора кредитования малого и среднего бизнеса, можно отметить, что в значительная часть региональных коммерческих банков успешно выходит на данный сегмент рынка. Накапливая опыт работы, оценивая уровень рисков, связанных с кредитованием малого и среднего бизнеса регионов, небольшие региональные коммерческий банки идут по пути упрощения процедур кредитования, в том числе через более привлекательные условия предоставляемых услуг, поскольку они наиболее хорошо знакомы с региональным бизнесом и экономикой региона.

По данным RAEX (на основе анкетирования кредитных организаций), объем заимствований, выданных банками малым и средним предпринимателям за первое полугодие 2016 года, составил 2,4 трлн. рублей. Это на 
0,6\% меньше, чем за аналогичный период 2015-го. При этом, отмечается в исследовании, размер портфеля кредитов МСБ за период с 1 июля 2015 года по 1 июля 2016 года сократился на 2\% и составил 4,6 трлн рублей по итогам полугодия [6].

Согласно данным Банка России от 12.01.2017 года, объем кредитов, предоставленных субъектам малого и среднего предпринимательства в миллионах рублей, иностранной валюте за период 2012-2016 году имеет отрицательный вектор снижения (рисунок 1).

На снижение объема выданных кредитных средств влияют не только вышеотмеченные факторы (финансовый кризис, рост ключевой ставки, растущие риски неплатежей в реальном секторе экономики), но и желание коммерческих банков снизить кредитные риски наиболее непопулярным путем, - ограничением выдачи кредитных средств в условиях финансового кризиса предприятиям малого и среднего бизнеса.

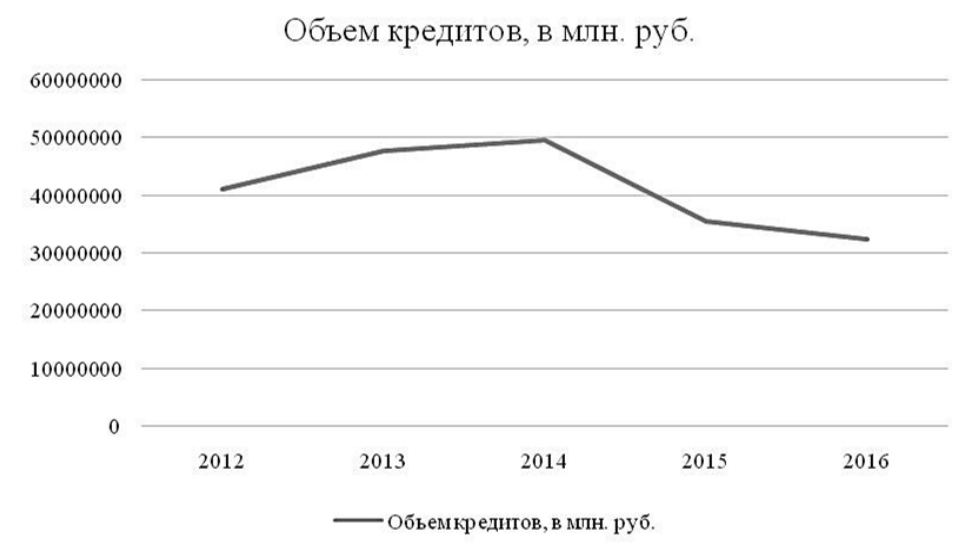

Рис. 1. Динамика объема кредитных средств предоставленных субъектам малого и среднего предпринимательства [7]

Крупные коммерческие банки, такие как Альфа-Банк, ВТБ 24, Сбербанк и другие, в 2015 году свернули кредитование малого бизнеса после декабрьского повышения Банков России ключевой ставки, что сказалось на ограниченности доступности кредитов для большинства компаний клиентов банк, особенно сильно ограничения коснулись предприятий малого и среднего бизнеса.

Проведенный анализ таблицы 1 , показывает, что объем кредитных средств, выданных малому и среднему бизнесу с 2012 года по 2016 год сократился на 20\%, что отразилось и на снижении ВВП России.

Резюмируя подчеркнем, отсутствие заинтересованности у федеральных банков на данном рынке кредитования приводит к резкому снижению объема кредитования малого и среднего бизнеса. Институты призванные снижать трансанкционные издержки в экономике, введя ограничения, привели к обратному результату - увеличению издержек для малого и 
среднего бизнеса, вынуждая последних искать средства в других источниках. Это подчеркивает рентоориентированное поведение коммерческих банков и их значительное влияние на поведение экономических субъектов $[8$, c. 57].

Таблица 1 Объем кредитов предоставленных субъектам малого и среднего предпринимательства в млн рублей [7]

\begin{tabular}{|c|c|c|c|c|c|}
\hline Отчетная дата & 2012 & 2013 & 2014 & 2015 & 2016 \\
\hline $\begin{array}{c}\text { Об̋ъем кредитов суббъектам малого и } \\
\text { среднего предпринимательства }\end{array}$ & 41167453 & 47633462 & 49568966 & 35438171 & 32391382 \\
\hline $\begin{array}{c}\text { \% снижения /прироста об̆ъема кредитов к } \\
\text { предыдущему году }\end{array}$ & & $15 \%$ & $4 \%$ & $-29 \%$ & $-9 \%$ \\
\hline
\end{tabular}

По результатам проведенного исследования, ставится очевидным необходимость совершенствования механизма взаимодействия коммерческих банков и предприятий реального сектора экономки. В первую очередь необходимо задействовать региональные коммерческие банки как наиболее гибкие и маневренные кредитные организации, специализирующихся на обслуживании предприятий малого и среднего бизнеса.

В частности, предполагается ряд мер по совершенствованию взаимодействия региональных финансово-кредитных институтов и реального сектора экономики, через механизм государственно-частного партнерства.

В первую очередь необходимо регламентировать для региональных коммерческих банков, которые осуществляют кредитование организаций реального сектора ряд льгот, позволяющих им снизить процентные ставки без потери прибыли. В частности, пересмотреть снижение ставок резервирования по выданным кредитам направленных на развитие реального сектора производства с 4,5\% до 2,5\%, это позволит коммерческим банкам снизить процентную ставку по кредиту на аналогичный процент.

Во-вторых, субсидировать часть процентной ставки кредитных ресурсов, направляемых на кредитование реального сектора экономики региона, из средств регионального бюджета.

Пересмотр процентной ставки банков для организаций малого и среднего бизнеса, позволит привлекать нераспределенные денежные средства клиентов по более выгодным для них условий, что в свою очередь, позволит рационально использовать свободные финансовые ресурсы в качестве кредитных средств, и благоприятно оценивать ликвидность банковского сектора, увеличить активы банков и обеспечить непрерывное движение денежных средств в экономической системе РФ.

В совокупности эти меры позволят использовать механизм государственно-частного партнерства на уровне взаимодействия региональных кредитных организаций и бизнеса, что отразится на процентной политике 
банков и эффективности реального сектора экономики, что в совокупности формирует благосостояние граждан региона.

Пересмотр институциональной роли региональных коммерческих банков, упрощение ряда требований к выполнению банковских нормативов [9. С. 47], предоставление льгот региональным банкам, участвующим в развитии реального сектора экономики регионов позволит вывести их в локомотивы экономического роста национального хозяйства современной России.

References:

[1] Поляк Г.Б. Финансы и кредит // ВолтерсКлувер. -2010. С. 37-39.

[2] Н.Г. Кузнецов, К.В.Кочмола, Е.Н. Алифанова Финансы и кредит // КНОРУС. 2016. C. 12.

[3] Взаимосвязь финансов и кредитов [Электронный ресурс]. Режим доступа: http://works.doklad.ru/view/Ab5ynDG9IwU.html

[4] Деньги. Кредит. Банк. Финансы. Инновации [Электронный ресурс]. Режим доступа: http://dkb-fin.ru/vzaimosvyaz_finansov_i_kredita.html

[5] Содержание финансовых отношений [Электронный ресурс]. Режим доступа: http://cde.osu.ru/demoversion/course7/t1_4.html

[6] Кредитование малого и среднего бизнеса прошло дно [Электронный ресурс]. Режим доступа: http://www.banki.ru/news/bankpress/?id=9134945

[7] Объем кредитов, предоставленных субъектам малого и среднего предпринимательства в рублях, иностранной валюте и драгоценных металлах [Электронный pecypc]. Режим доступа: http://www.cbr.ru/statistics/UDStat.aspx?TblID=302-17

[8] Корешков В.Г. Оценка потерь общества от рентоориентированного поведения коммерческих банков // Проблемы учета и финансов. 2013. № 4. С. 57-60.

[9] Корешков В.Г., Швецов Ю.Г. О возможности дифференцированного подхода к оценке стоимости капитала банков // Деньги и кредит. 2015. № 10. С. 44-47. 


\section{DEVELOPMENT OF METHODICAL APPROACHES TO THE CREATION OF NEW KNOWLEDGE-BASED GROWTH POINTS}

\section{Abuzyarova ${ }^{1}$}

\section{Abstract}

Object of research in the proposed article is spatial economics, advanced forms of organization and interaction of industries, territorial entities and integration associations in the space. Emphasis is placed on the concepts of "poles" or "growth centres". In market conditions the role of spatial factors in the development of the economy has increased and changed. Spatial development policy is an ongoing process of review and adjustment, mechanisms for its implementation are constantly changing to ensure its usefulness in a changing world.

Keywords: knowledge-based economy, spatial economics, spatial development policy, smart specialisation, institutions, institutional mechanism

The main purpose of forming a new spatial development policy is to ensure the balanced development of its territory, with emphasis on the creation of knowledge-intensive industries based on efficient specialization economy of regions and population equal access to social services, i.e. inclusive development.

As the basis for the formation of the spatial economic development policy must be taken on the following principles:

-unity of the strategic development of the territory of the country, taking into account the interests of the authorities, business and population;

-sustainability in territorial development, based mainly on the formation of knowledge-based sectors of the economy, the improvement of the regional structure and ensuring an inclusive social development;

-openness and publicity of decision-making in the field of spatial development;

-concentration of resources and urban architectural activity in growing points, etc.

Control system of the territory development must be based on a spatial approach, which important elements are:

-raising the level of territorial mobility of the factors of production, development of inter-regional and international economic relations, that implies the development of market, production, transport, communications and logistics infrastructure;

-placement of industrial enterprises in terms of efficiency potential of regions, diversification of the regional economic structure, and "growth points" based on "smart" specialization;

${ }^{1}$ Mariya Abuzyarova, Ph.D. in Economics, Samara state university of economics, Department of "Marketing", Russia. 
-small business development to meet the basic needs of the population and to service production sector;

-ensuring inclusive development of space in the country in terms of equal access of the population of all the regions and localities to social benefits and services.

Spatial development policy implementation priorities should be:

-sustainable development as a system combination of economic, social and environmental aspects of the spatial development of the country;

-ensuring social standards for the inhabitants of cities and villages, resettlement of the population with a view to achieve effective development of regional economies;

-formation of urban agglomerations, the establishment of a network of truly new "smart" and "green" satellite cities;

-balance of entrepreneurial initiatives, investor needs and strategic priorities for the development of the region [1].

Implementing the principles of "smart" specialization in practice goes through the formation of appropriate governance arrangements.

This term is quite widely used by the representatives of the various branches of knowledge.

Unified view of its content was not emerged yet.

To implement the principle of inclusive spatial development of each type of service it is necessary to form the corresponding institutional control mechanism.

In economics and management, the use of the term "mechanism" in various phrases is used quite widely.

The most common concepts include: economic management mechanism, control mechanism, economic regulation mechanism, organizational-economic mechanism, etc.

The number of generalized interpretations of this concepts include a set of levers used in the management "[2, P. 61].

In our opinion, these concepts can be used when describing the considered phenomena and are predominantly cognitive in nature.

To investigate the specific theoretical problems and to solve practical problems they are of little use because cover too wide a range of subject areas, each of which has an inherent object of study, the subject and appropriate methodology.

The second group consists of concepts that are more specific. When using such interpretations, a mechanism is considered, primarily, as a result of the interaction of individual elements in the various processes and phenomena, occurring in the economy and governance.

To solve the methodological and practical problems more constructive is the second position, because it is more consistent with the fundamentals of the theory of mechanisms, as well as is of great value for making of specific decisions.

In economy the management mechanism model is the control loop. 
A study of the literature indicates that most authors consider the simplest model of the control loop as a closed circuit consisting of the managing and managed subsystems. Other formulations differ little from this, because it is the most complete [3].

In our opinion, the control loop is a dynamic model of the used control mechanisms, which reflects the content of the processes occurring in the control system.

In our interpretation the control loop is the primary element of the system of governance, which is the basis for building of the institutional management mechanism.

In a separate control loop is carried out a process to achieve the target goal through the transformation of information reflecting the status of processes and phenomena occurring in the control object to the appropriate management actions.

The core of control circuit constitute objectives, set of various types of management actions required to achieve them, as well as the composition of the functions that make up the management cycle, within which are carried out full administration activities.

The goal is an expected result, acting as the unity of desired and possible, determined on the basis of foresight and economic calculations.

In the management it has the fundamental place, because a correctly formulated goal can determine the composition and content of the used economic regulators, fulfilled functions of the organs of governance and used information.

As a control object can serve the public and private sector, providing services to the population and businesses engaged in innovation activity in a particular region.

A regulating unit consists of scientifically based set of economic forms, methods and tools, that are used to achieve the stated objectives.

An institutional unit in its content is the foundation of the public institutional mechanism.

Characteristics of these management system components are reflected in the relevant normative legal acts, which constitute the institutional control mechanism, that regulates a certain kind of economic activities to provide services to the population of the regions.

Institutional mechanism includes two types of control loops:

-in the activities of public authorities in relation to private sector organisations, which operate in a free market.

- includes aims, objectives and management functions in relation to organizations whose activities are financed from the budget.

The key importance in this control loop belongs to the information unit, reflecting the level of provision of the population with services.

In this regard, it is necessary to determine:

-regulated field of activities, for which can be set a measurable result.

-regulator (composition of the regulators), used to achieve the target end result in a regulated activity. 
-functions of the authorized body responsible for use of the appropriate regulator.

The proposed methodology would in practice determine the nature of organizational and information links within the framework of the implementation of the principles of inclusive spatial development and smart specialization.

\section{References:}

[1] Minakir P.A. About spatial economics and spatial development//Economist. -2011. №9. -P. 37-41

[2] Perru F. Economic space: theory and practice//Spatial Economics. -2007. №3. -P. 1725.

[3] 3. Ukrainsky V.N. Economic space in a mirror of the territorial economy//Spatial Economics. -2014. № 2. -P. 177-186. 


\section{DEVELOPMENT OF METHODICAL APPROACHES TO THE RESOURCE EFFICIENT USE OF HYDROCARBONS}

\section{O. Andreev ${ }^{1}$}

This article is aimed at improving of the resource efficiency use of hydrocarbon, which will help to implement the complex energy and environmental-economic goals to move towards "green" development. A leading approach to the investigation of this issue is the policy of resource conservation, which will reduce production costs and enhance competitiveness of the national economy. Solving these problems will allow the use of valuable hydrocarbon raw materials, obtain products with high added value.

Keywords: the oil and gas industry, hydrocarbon resources, resource efficiency, sustainable development, innovative transformation, comprehensive use, ecological and economic efficiency.

Resource efficiency is a process of the rationalizing use of all kinds of materials, labor, financial and other resources mostly based on the production efficiency.

Development of directions of the integrated use of produced hydrocarbon raw materials is contingent on the fact that in the nearest future is planned to increase exploitation of pre-salt complex due to the introduction of new capacity.

In this regard, in order to prevent ecological and economic problems should be accelerated introduction to processes of extraction and processing of oil and gas resources.

One of the most important priorities in the development of oil and gas enterprises is the improvement of technological processes and the introduction of innovative equipment, organization of low-waste resource-saving production.

Great importance gets solving the problem of disposal of propylene, butylenes by creating production complexes of polypropylene and methyl tertiarybutyl ether (MTBE), which is an additive to obtain high-octane ecologically-clean gasoline [1].

Due to the high oxygen content of MTBE increases detonation properties and allows to save oil resources in the production of fuel.

The integrated use of hydrocarbons, the rational use of secondary products, the maximum involvement of heavy oil residues will contribute to increasing resource efficiency and environmental safety.

In world practice is applied a comprehensive programme for development of oil and gas fields, where hydrocarbons are extracted and processed with a high level of resource efficiency, aimed at obtaining economic gain and maximum ecological safety.

${ }^{1}$ Oleg Andreev, Ph.D. in Economics, Samara state university of economics, Department of "Economy, organization and development strategy of the company", Russia. 
At the present stage of development of oil and gas complex is necessary to solve problems of production volumes growth with simultaneous reduction of environmental load on the environment, it means, achieving the effect of "decoupling".

Achieving that is possible through the widespread introduction of innovative technologies of deep processing of oil and gas resources, aimed at the resource efficient use of raw material on the basis of comprehensiveness, rationality and avoidance of waste.

The implementation of these measures will significantly reduce environmental risks and go out on a path of sustainable development of the national economy, which will facilitate the transition to a "green" development of not only oil and gas complex, but also the national economy [2].

Modern ecological situation predetermines the necessity of regulation of technogenic influence on the environment environment, that is impossible without implementation of rational and resource efficient use of hydrocarbons, i.e. necessary is comprehensive ecologization of all production processes of oil and gas complex.

Ecologization of oil refineries within the concept of sustainable development implies increasing their efficiency and reducing resource consumption, i.e. achievement of the decoupling effect in which production should be aimed at improving resource efficiency and simultaneous reduction of waste and emissions, i.e. to minimize environmental risks.

Oil and gas production and oil refining industries are characterized by high losses of resources that reach $60-80 \%$ of the feedstock.

A huge losses of oil and gas resources in the extraction and processing indicate that it is necessary to adopt measures aimed at maximum utilization of natural and associated gas and integrated use of liquid hydrocarbons.

The need for comprehensive utilization of raw materials is also dictated by the fact that oil and gas contain large amounts of valuable components, and their allocation to the individual products will enhance the economic benefits.

Non-Integrated processing of raw resources entails significant losses:

-when processing oil is extracted from a mixture of different grades of oil that is not conducive to rational and efficient use of raw materials;

-processing of mixtures of different grades of oil leads to deterioration of the oil refining production settings, rapid wear of the equipment, reduce the quality of the finished product, receiving substandard lubricants [3].

Simultaneous processing of grades of oil with different physical and chemical composition, entails the loss of quality characteristics that are inherent in each of them. As a result, this leads to a decrease in the release of high-quality grades of gasoline, production of various types of oils, wide range of raw materials for the petrochemical industry.

Hydrocarbon resources are non-renewable, and therefore their resource efficient use becomes a priority in the development of oil refining.

The resource efficient use of raw materials implies rational and integrated processing without a reduction in the quantity. 
Oil is a multi-component raw materials containing composed a number of valuable components.

When it is used in integrated fullest volume all the useful components are extracted, and the waste products can be converted into new products. Integrated utilization increases industrial efficiency, ensures an increase in the volume and production spectrum, cost savings and cost reduction in the creation of raw material bases, prevents pollution of the environment with production waste.

Disengagement simultaneously with fuel fractions of other valuable components is the main direction of rational and complex use of hydrocarbons.

Questions of production of hydrocarbons should be solved simultaneously with the integrated processing, including the disengagement of metals in pure form, that is economically profitable, because metals can be sold at high prices on world markets.

Analysis of complex processing of oil shows that one of the most promising is the technology, which include provisional demetallization of oil at the wells with $60 \%$ vanadium, asphaltenes, subsequent hydrocracking with utilization of sulfur-containing compounds and the produce of light hydrocarbon fractions, as well as the regeneration of dead-catalysts.

Vanadium is extracted from oil fields with obtaining a concentrate, providing an increase of complex utilization of raw materials. Demetallized oil is subjected to hydro treating, emitting hydrogen sulphide, and later elemental sulfur.

Stage of oil hydrocracking on the catalysts allows to increase the yield of light hydrocarbon fractions. Vanadium concentrate and dead-catalysts are processed on extraction technology in obtaining pure vanadium oxide. The proposed technological scheme provides extraction of vanadium at the level of $80 \%$, sulfur$92 \%$ and an increase in the output of diesel fuel for 25\% [4].

One of the promising ways of direct extraction of metals from oil is polymineral processing of hydrocarbonic raw materials with acetic anhydride followed by exposure of hydrogen peroxide.

Vanadium organic compounds, present in the oil, are major regulators of oil emulsions, that impede their destruction.

Complex processing of raw materials is possible only with high organization of production with high-tech equipment. It involves the use of complex technological processes with deep processing that allows to extend the product range.

Thanks to the development of innovative technologies for processing oil and gas resources have acquired the status of the unique source of a wide range of products.

Only in this case, you can talk about resource efficient spending of hydrocarbons, about the real possibilities of obtaining significant ecological and economic effect.

Economic efficiency of integrated use of raw materials is determined by the reduction in resource consumption and economy of financial and manpower resources in the manufacturing of final consumption.

Low-waste and non-waste technologies, aimed at improving resource efficiency, should be based on complex processing of hydrocarbonic raw materials taking into account the use of its mineral components, recycling of production 
waste in compliance with environmental legislation, the release of products that can be recycled.

Recover with oil associated petroleum gas (APG) is an essential resource for obtaining a wide range of polymer products in case of integrated use. Depending on the contents of individual hydrocarbons the whole technological cycle of processing is built in it.

Based on the composition of the associated petroleum gas can be calculated its potential value, as well as determined the most rational schemes of its use as an energy resource, or as raw material for petrochemical industry. Based on the information about volume and composition of APG are carried decisions on equipping of production facilities and oil and gas pretreatment with appropriate equipment, both in capacity and in terms of used equipment and technological processes.

The depletion of easily accessible oil reserves compels to produce hard recoverable raw materials, leading to a rise in the value of its production, predetermines a need to search for alternatives.

There is a problem of generating synthetic liquid hydrocarbons from the hydrocarbon feedstock.

As these sources can be called natural and shale gases, associated petroleum gas, as well as refinery gases.

Recycling of associated gas, for example, is of great importance both in terms of the rational use of this valuable raw material, and from an environmental point of view, because, as a result, will solved the problem of $\mathrm{co2}$ emissions into the atmosphere. In addition, hydrocarbon gases contain more or fewer sulfur compounds, such as carbon disulfide, carbonyl sulfide, mercaptans [5].

Liquefied petroleum associated gases are high-quality automobile fuel, highoctane and environmentally friendly.

Difficulties in using them occur only in their distribution. At the same time inevitable are significant costs of establishing gas storage facilities and equipment for vehicles.

The main obstacle to the widespread use of liquefied gas in road transport should be considered as their limited volume and the presence of other users, as they are used in the petrochemical industry, agriculture and domestic economy, is widely used for welding and cutting metal.

Thus, in order to improve the resource efficiency of use of hydrocarbons in refineries should be a number of tasks, including:

-increase in the level of resource efficiency in the use of hydrocarbon resources on the base of its integrated and rational use;

- achieving decoupling effect, implying to meet the growing needs of the economy while minimizing depletion and exhaustion of natural resources potential;

-increasing the degree of involvement in the processing of natural and by passing oil gas, as well as increasing the efficiency of their utilization;

-development of knowledge-intensive resource-saving and resource-efficient high-tech industries;

-full use of raw resources and minimizing the size of waste during processing and environmental damage; 
-development of environmentally sustainable economic activity of the processing industries;

-introduction of small tonnage refineries and mini-refineries;

-stimulation of subsoil users at the state level to the use of modern and innovative waste-free and low-waste technologies.

\section{References:}

[1] Abrosimov A.A. Ecology of processing of hydrocarbon systems. M.: Chemistry. -2002. 608 P.

[2] Tetelmin B.V., Yazev V.A. Environmental protection in the oil and gas industry. -Dolgoprudny: Publishing House «Intellect». -2009. -352 P.

[3] Filatov V.V., Kulikova N.V., Rukina I.M., Konotopov P.Y. Situational analysis of ensuring innovative development of economy of the Russian Federation//scientific journal of the National Research University of Information Technologies, Mechanics and Optics A series "Economics and environmental management". №2. -2014. -P. 23-37.

[4] 4 Tumanyan B.P. On assessing the effectiveness of functioning refineries//Chemistry and technology of fuels and oils. No. 3 (553). -2009. P. 4-6.

[5] Bessonova T.N. Alternative solutions of solving environmental problems//Journal of Yugra State University.- Vol. 5. -2006.- P.12-16. 


\title{
COMPETITIVENESS ASSESSMEHT BASED ON SWOT-ANALYSIS
}

\author{
M. Sheaa ${ }^{1}$
}

\section{Abstract}

SWOT analysis is one of the most effective tools for assessing competitiveness. It allows identifying and structuring the strengths and weaknesses of the organization, as well as potential opportunities and threats. The evaluation of the quality of the conformity concluded in which direction the organization should develop its business and determines the allocation of resources according to business segments.

Keywords: competitiveness, SWOT-analysis, opportunities and threats, strengths and weaknesses, management efficiency.

Финансовое состояние любой организации зависит от того, насколько успешно она способна реагировать на различные внешние воздействия. Анализируя внешнюю ситуацию, необходимо выделять наиболее существенные на конкретный период времени факторы. При решении разного уровня задач необходимо также четко представлять, поддаются ли критические факторы контролю со стороны организации. Одним из самых распространенных методов, оценивающих в комплексе внутренние и внешние факторы, влияющие на развитие организации можно назвать SWOTанализ [1, с.106].

SWOT-анализ является классическим направлением оценки конкурентоспособности организации и заключается в изучении сильных и слабых сторон деятельности организации, а также возможностей и угроз со стороны внешней среды. На основе результатов SWOT-анализа можно определить, обладает ли организация внутренними силами и ресурсами, чтобы реализовать имеющиеся возможности и противостоять угрозам, какие внутренние проблемы требуют скорейшего решения [2, с. 174].

Неотъемлемыми процедурами SWOT- анализа является внутренний аудит и аудит внешней среды. В процессе проведения внешнего аудита оценивается привлекательность рынка и другие возможности, а также угрозы внешней среды. При этом, оценивая привлекательность рынка, следует обратить внимание на тенденции рынка (развитие спроса в каждом сегменте бизнеса), поведение покупателей (покупательские привычки и предпочтения), конкурентную среду (рыночную силу поставщиков и конкурентов, угрозы товаров субститутов, (заменителей), барьеры входа на рынок).

В процессе проведения внутреннего аудита оцениваются ресурсы организации, ее бизнес-процессы, анализируется конкурентоспособность. В

${ }^{1}$ Mutana T. Sheaa, Master of Economics, National Research Ogarev Mordovia State University, Russia. 
процессе проведения анализа изучается потенциал сотрудников организации, их квалификация, мотивация, лояльность; коммуникационные программы (реклама, личные продажи, PR), сравнение рекламной активности с конкурентами, эффективность собственных маркетинговых усилий.

Перечисленные факторы не являются исчерпывающими. В зависимости от специфики бизнеса и рынка могут быть выявлены и другие факторы, требующие тщательного детализированного анализа. Важно не только объективно оценить параметр, но и выбрать среди их множества ограниченный ряд наиболее важных показателей выживаемости, развития, роста и прибыльности бизнеса [3, с. 59].

Рассмотрим процесс проведения SWOT-анализа на основе данных публичной отчетности государственного унитарного предприятия Республики Мордовия «Тепличное». Это современное агропромышленное предприятие, основной поставщик овощной продукции города Саранска и Республики Мордовия, а также в другие регионы страны. Основное направление деятельности - производство овощей закрытого и открытого грунта, картофеля и зерна. На ГУП «Тепличное» были построены и введены в эксплуатацию объекты производственного назначения: салатная линия для выращивания зеленных (салат, базилик, щавель, укроп, сельдерей, петрушка), цветочная теплица, современные теплицы для выращивания томатов по голландской технологии. Для характеристики финансового положения организации рассмотрим основные показатели, характеризующие наличие, размещение и использование финансовых ресурсов (таблица 1).

Таблица 1

Основные показатели финансово-хозяйственной деятельности ГУП РМ «Тепличное» за 2014-2015 гг.

\begin{tabular}{|l|c|c|c|c|}
\hline \multicolumn{1}{|c|}{ Показатель } & \multirow{2}{*}{2014 г. } & 2015 г. & \multicolumn{2}{|c|}{ Отклонение } \\
\cline { 4 - 5 } & & & $\begin{array}{c}\text { абсолютное } \\
(+.-)\end{array}$ & $\begin{array}{c}\text { Темп роста, в } \\
\%\end{array}$ \\
\hline Стоимость имущества, тыс. р. & 953918 & 1028162 & 74244 & 107,78 \\
\hline $\begin{array}{l}\text { Удельный вес основных средств в сто- } \\
\text { имости имущества, в \% }\end{array}$ & 70,47 & 74,42 & 3,95 & 105,6 \\
\hline $\begin{array}{l}\text { Величина собственных источников } \\
\text { финансирования, тыс.р. }\end{array}$ & 761849 & 820052 & 58203 & 107,64 \\
\hline $\begin{array}{l}\text { Удельный вес собственных средств в } \\
\text { общей величине финансовых ресур- } \\
\text { сов, в \% }\end{array}$ & 79,87 & 79,76 & $-0,11$ & 99,87 \\
\hline Коэффициент текущей ликвидности & 18,13 & 18,22 & 0,09 & 100,48 \\
\hline Рентабельность продаж, в \% & 14,15 & 10,63 & $-3,52$ & 75,12 \\
\hline Рентабельность продукции, в \% & 18,12 & 13,12 & $-5,00$ & 72,42 \\
\hline $\begin{array}{l}\text { Рентабельность собственного капи- } \\
\text { тала, в \% }\end{array}$ & 10,13 & 7,36 & $-2,77$ & 72,62 \\
\hline
\end{tabular}


На основании таблицы 1 можно сделать следующие выводы. Стоимость имущества увеличилась на 74244 тыс.р. или на 107,78 \%. Удельный вес собственных средств в общей величине источников финансирования составляет почти $80 \%$, что характеризует высокий уровень финансовой независимости предприятия. Платежеспособность предприятия является достаточно высокой, так как активы значительно превышают величину. Рентабельность продаж в отчетном году составила $10,63 \%$; рентабельность затрат на производство проданной продукции - 13,12\%. Важным является то, что показатель рентабельности затрат демонстрирует степень окупаемости расходов по конкретным направлениям деятельности, т.е. данный коэффициент показывает уровень прибыли на один рубль затраченных средств. Рассмотрим сильные слабые стороны деятельности ГУП PM «Тепличное». Как известно, внутренние факторы контролируются менеджментом организации (таблица 2).

Таблица 2

Сильные и слабые стороны деятельности ГУП РМ «Тепличное» за 2014-2015 гг.

\begin{tabular}{|c|c|c|}
\hline Параметры оценки & Сильные стороны & Слабые стороны \\
\hline Организация & $\begin{array}{l}\text { ГУП РМ «Тепличное» имеет проч- } \\
\text { ную репутацию на региональном } \\
\text { рынке четко сформулированную } \\
\text { стратегию развития; располагает } \\
\text { высококвалифицированным пер- } \\
\text { соналом. }\end{array}$ & $\begin{array}{l}\text { В производстве овощей и } \\
\text { обработке сельхозугодий } \\
\text { востребованы дефицит- } \\
\text { ные рабочие специально- } \\
\text { сти: трактористы, комбай- } \\
\text { неры, сварщики, сантех- } \\
\text { ники. }\end{array}$ \\
\hline Производство & $\begin{array}{l}\text { Продукция имеет высокую } \\
\text { оценку качества; наличие цеха } \\
\text { овощных консервов позволяет } \\
\text { переработку нестандартных ово- } \\
\text { щей; овощехранилища позво- } \\
\text { ляют сохранять и торговать све- } \\
\text { жими овощами открытого грунта } \\
\text { до мая месяца }\end{array}$ & $\begin{array}{l}\text { Высокая } \\
\text { продукции } \\
\text { грунта. }\end{array}$ \\
\hline Финансы & $\begin{array}{l}\text { Устойчивое финансовое положе- } \\
\text { ние }\end{array}$ & $\begin{array}{l}\text { Недостаточное финанси- } \\
\text { рование }\end{array}$ \\
\hline Маркетинг & $\begin{array}{l}\text { Наличие налаженных каналов } \\
\text { сбыта, удобное расположение на } \\
\text { транспортной магистрали, нали- } \\
\text { чие специального транспорта } \\
\text { для перевозки овощей }\end{array}$ & $\begin{array}{l}\text { Негибкая политика ра- } \\
\text { боты с клиентами }\end{array}$ \\
\hline
\end{tabular}

Второй шаг SWOT-анализа - это своеобразная разведка местности, оценка рынка. Методика определения возможностей и угроз практически идентична методике определения сильных и слабых сторон предприятия [4, c.78]. Для ее проведения необходимо заполнить таблицу 3. 
Таблица 3

Возможности и угрозы ГУП РМ «Тепличное» за 2014-2015 гг.

\begin{tabular}{|c|c|c|}
\hline Параметры оценки & Возможности & Угрозы \\
\hline Конкуренция & $\begin{array}{l}\text { Расширение диапазона возмож- } \\
\text { ных продовольственных това- } \\
\text { ров. Возможность обслуживания } \\
\text { дополнительных групп потреби- } \\
\text { телей, реконструкция и модерни- } \\
\text { зация производства }\end{array}$ & $\begin{array}{l}\text { усиления конкуренции с } \\
\text { тепличными комбинатами } \\
\text { Поволжья, поставки им- } \\
\text { портной овощной продук- } \\
\text { ции }\end{array}$ \\
\hline Сбыт & Увеличение емкости рынка & $\begin{array}{l}\text { влияние природно-клима- } \\
\text { тических условий }\end{array}$ \\
\hline $\begin{array}{l}\text { Экономические фак- } \\
\text { торы }\end{array}$ & $\begin{array}{l}\text { Государственная политика им- } \\
\text { портосбережения, предоставле- } \\
\text { ние льготных кредитов }\end{array}$ & $\begin{array}{l}\text { Изменение предпочтений } \\
\text { потребителей из-за высо- } \\
\text { ких цен на продукцию }\end{array}$ \\
\hline Правовые факторы & $\begin{array}{l}\text { Национальный проект «Развитие } \\
\text { АПК» }\end{array}$ & $\begin{array}{l}\text { Высокая подверженность } \\
\text { влиянию изменения зако- } \\
\text { нодательства }\end{array}$ \\
\hline
\end{tabular}

Таким образом, на основании проведенного SWOT- анализа можно определит основные тенденции дальнейшего развития организации. Чтобы на практике избежать возможных ошибок и извлечь максимум пользы из SWOT- анализа необходимо максимально конкретизировать сферу его проведения, соблюдать корректность при отнесении того или иного фактора к силам /слабым сторонам или возможностям/угрозам. SWOT- анализ должен показывать реальное положение и перспективы развития организации; ориентироваться на объективное использование разносторонней информации.

References:

[1] Анализ инвестиционной привлекательности организации / под ред. Д.А. Ендовицкого. М.: Кнорус, 2017. 376 с.

[2] Белер Геймо. Методы исследования рынка. Харьков: Гуманитарный центр, 2013. 294 c.

[3] Горбунова Н.А. Определение стоимости бизнеса: финансовый и стоимостной подход // Новый университет. Серия Экономика и право. 2016 -5 (63) С. 57-61

[4] Рыжикова Т. Н. Аналитический маркетинг: что должен знать маркетинговый аналитик. М.:Инфра-М, 2014. 288с. 


\section{SOCIAL TOURISM AND ITS DEVELOPMENT PROSPECTS IN THE REGION}

\section{Kenzhebayeva ${ }^{1}$}

\section{Abstract}

Among the factors that are weaknesses for the development of tourism in Kazakhstan, stated the following: the demand for travel services in Kazakhstan is limited by the material capabilities of citizens, the lack of standards to be applied to certain types of placements, and the rules of regulation of social tourism, applied in respect of workers and employers. The development of social tourism is very important in our time, since social tourism - this kind of tourism, which is subsidized by the state and is designed for virtually all categories of citizens. As a result, you can identify the following prospects for the development of social tourism. As well as the development of medical and health and sports tourism, as a necessary condition for the formation of a healthy nation.

Keywords: tourism, social tourism, tourism industry, tourist activities, tour operator, travel agent, the demand for vacation, recreation.

В современных реалиях индустрия туризма является одним из наиболее интенсивно развивающихся и перспективных секторов экономики. Невозможно переоценить его воздействие на экономику. Туристическая отрасль представляет значительную часть глобальной экономики, занимая третью строчку мирового экспорта. Доходы мирового туризма, полученные от пребывания путешественников в зарубежных странах, выросли на $3,6 \%$ в 2015 году и составили в \$1,232 млрд, включая расходы на размещение, питание, развлечения и магазины. При этом туризм остается самой быстрорастущей отраслью в мировом экспорте, в среднем доходы туристической отрасли составляют \$4 млрд в день [1]. Спрос на отдых - вот новая форма потребительского спроса. Предприятия туристской индустрии в первую очередь создают новые рабочие места. Увеличение доходов туристских фирм способствует увеличению поступлений в бюджеты различных уровней.

Характеризуя значение туризма как отрасли рыночной экономики, необходимо отметить его социальную значимость, возрастающую роль в духовном и физическом развитии личности, формировании уровня и качества жизни [2]. В туризме важно не только коммерческое начало, но и его познавательная и воспитательная функции. Туризм, как отрасль рыночной экономики, должен иметь социальную направленность. А рынок туристских услуг должен быть социально ориентированным.

${ }^{1}$ Marina Kenzhebayeva, M.Kh. Dulaty Taraz State University, associate Professor of Economics, Kazakhstan. 
Во Всеобщей декларации прав человека отмечается, что все люди имеют право на отдых, свободное время, ограничение часов работы и оплачиваемый отпуск. Учитывая это, необходимо бороться за использование отдыха и туризма для удовлетворения человеческих потребностей на основе, уже заложенной социальным туризмом. Его главной целью всегда было обеспечение возможностей для всех путешествовать и отдыхать [3].

Современное состояние казахстанского общества требует развития социального туризма, который дает возможности оздоровления, познания, приобщения к культурным ценностям средствами туризма, способствует переориентации казахстанцев к ведению здорового образа жизни и духовности. Социальный туризм важно и нужно развивать в Казахстане. Ведь все граждане страны вне зависимости от их доходов и физиологических особенностей имеют равные права к доступу на отдых. Но для того чтобы развивать социальный туризм необходимо в первую очередь решать проблемы, с которыми сталкиваются желающие развивать социальный туризм. А именно: отсутствие стандартов, отсутствие специалистов, отсутствие доступных туристических объектов, отсутствие доступного транспорта, отсутствие финансирования социального туризма, отсутствие ответственности государственных органов и коммерческих фирм.

Наиболее сложной и трудноразрешимой проблемой является поиск источников его финансирования, а при наличии таковых - в системе распределения финансовых средств среди малоимущих категорий лиц, имеющих предпочтительное право на льготы.

Обеспечение доступности туристского отдыха для многодетных семей, молодежи и пожилых лиц, требует разработки и осуществления конкретных мер, к числу которых относятся определение социальной туристской политики государства, принятия собственных законодательных и нормативных актов, создание социальной инфраструктуры, обеспечение систем и механизмов поддержки малообеспеченных слоев населения, подготовка работников системы социального туризма, включая его организаторов, информационная работа и многое другое.

Социальный туризм - это организация отдыха для людей, которые не могут путешествовать самостоятельно, для которых существуют социальные, физические, психологические барьеры.

Основными формами социального туризма традиционно называют: детский туризм, семейный туризм, для пожилых (пенсионеров), спортивный туризм, лечебно-оздоровительный, самодеятельный туризм, туризм для людей с ограниченными возможностями (инвалидов).

На 23.01,2015 в Казахстане число инвалидов составляет 627 тыс. человек, что составляет $3,7 \%$ от общего числа населения. В том числе, детей инвалидов более 65000 тысяч [4]. Рынок туризма для людей с инвалидностью достаточно велик и не требует больших расходов. Развитие туризма и социального туризма в частности - выгодное для государства дело.

Учитывая вышесказанное, можно сказать, что социальный туризм, как разновидность туризма, имеет свои характерные черты:

- доступность для малообеспеченных людей с учетом их возраста, здоровья, социального положения, возможности их доступа к туризму; 
- предоставление льгот не только по возрастному цензу и по материальной несостоятельности, как поощрение наиболее активных работников за личный вклад в успех предприятия, организации, учреждения, стимулированием эффективного труда;

- преобладание коллективных и организованных форм в социальном туризме;

- на уровне конкретного потребителя турпродукта социальный туризм представляет собой бесплатные и льготные путевки в дома отдыха, санатории, турбазы и т.д.;

- развитие социального туризма способствует развитию регионов Республики Казахстан.

В тоже время, социальному туризму, как фактору развития общества, не уделяется должного внимания, что увеличивает социальную напряженность в обществе. Рост доходов населения не соответствует не только росту стоимости услуг в сфере туризма, но росту стоимости других товаров и услуг, характеризующих жизненный уровень населения. В итоге потребность людей в отдыхе является остается не удовлетворенной. Большая часть населения страны являясь потенциальными клиентами социальных форм туризма, на практике реализуют самодеятельный отдых, не пользуясь услугами туристских фирм. Это ведет к появлению других проблем. Это вопросы профилактики здоровья населения, рационального использования свободного времени, удовлетворения образовательных и культурных потребностей и другие.

Государство признало туристскую деятельность приоритетной отраслью экономики. Но продекларированные в Законе Республики Казахстан от 13 июня 2001 года N 211 «0 туристской деятельности в Республике Казахстан» приоритетные направления государственного регулирования туристской деятельности по поддержке и развитию внутреннего, въездного, социального и других видов туризма так и остались нереализованными [5]. Туризм в Казахстане так и не стал пока экономически выгодной отраслью.

Одним из путей развития социального туризма в нашей стране мог бы служить конструктивный диалог государства и крупного бизнеса. Конечно, основной задачей бизнеса является развитие производства. Однако в рамках конструктивного диалога можно и нужно определить приоритеты и создать механизмы партнерских отношений по вопросам развития малого туристского предпринимательства, развития основ социальной туристской политики. В послании Президента народу Казахстана «Казахстанский Путь -2050» одним из главных пунктов названо развитие социальной сферы, в том числе развитие здорового образа жизни, медицины и культуры. Ведь самое главное в государстве - это общество. Развитие медицины и внутреннего потенциала казахстанцев - есть фундамент для развития страны в целом [6].

Утверждение здорового образа жизни и развитие медицины позволят увеличить продолжительность жизни казахстанцев до 80 лет и выше, а также качество жизни. Мы планируем, что Казахстан станет одним из ведущих евразийских центров медицинского туризма. Казахстан может и 
должен стать одной из самых безопасных и комфортных для проживания людей стран мира. Занятия спортом, правильное питание, регулярные профилактические мероприятия - это основа предупреждения и профилактики заболеваний. Достижение данных стратегических целей невозможно без развития лечебно-оздоровительного туризма.

Исторически социальный туризм в Казахстане реализовывался через санаторно-курортный комплекс. Был неразрывно связан с рекреационной деятельностью людей, которая осуществляемая с целью восстановления физических сил, а также для его всестороннего развития.

C точки зрения санаторно-курортной деятельности Жамбылская область обладает огромным потенциалом. Она наделена необходимыми природными ресурсами, на основе которых созданы санаторно-курортные зоны с необходимыми условиями лечения и отдыха в санаториях-профилакториях и других лечебных учреждениях. Наибольшей популярностью пользуются такие как санаторий «Мерке», санаторий «Ак-Ниет», санаторий-профилакторий «Самал» и санаторий им.Турара Рыскулова. В общий комплекс санаторно-курортного лечения данных здравниц входят не только традиционные методы лечения, такие как физиотерапия, ингаляция, «морские» ванны и другие, но и нетрадиционные - мануальная терапия, кумысолечение, фитолечение.

В постиндустриальном обществе качество жизни населения Казахстана, главный показатель которого - здоровье, невысокое.

Одним из способов решения данной проблемы в настоящее время можно назвать распространение спортивно-оздоровительных комплексов, включающих большой спектр услуг.

Можно выделить следующие перспективы развития социального туризма. Во-первых, совершенствование законодательной базы в отношении социального туризма. Во-вторых, государству необходимо сотрудничество с крупным бизнесом, некоммерческими, благотворительными организациями. В-третьих, развитие лечебно-оздоровительного и спортивного туризма, как залога здоровья нации.

References:

[1] UNWTO Онлайн]Ссылка: http://www2.unwto.org/

[2] Квартальнов В.А. Мировой туризм на пороге 2000 года: Прогнозы и реальность. - М.: Финансы и статистика, 1998. - 11 с.

[3] Всеобщая декларация прав человека. Принята резолюцией 217 A (III) Генеральной Ассамблеи ООН от 10 декабря 1948 года Онлайн]Ссылка:http://www.un.org/ru

[4] Онлайн]Ссылка:http://bnews.kz

[5] О туристской деятельности в Республике Казахстан Закон Республики Казахстан от 13 июня 2001 года N211 Онлайн] Ссылка:; http://egov.kz

[6] Казахстанский путь-2050: Единая цель, единые интересы, единое будущее. Послание Президента Республики Казахстан от 17 января 2014 года Онлайн]Ссылка: http://egov.kz 


\section{THE STATE AND PROBLEMS OF LIVESTOCK PRODUCTION IN KAZAKHSTAN}

O.Zh. Dossymova ${ }^{1}$, D. Atasheva ${ }^{2}$, N.Zh. Dossymova ${ }^{3}$

\section{Abstract}

Livestock and crop production were the main driving factors of economic development of Kazakhstan. Agro-industrial complex is among the seven priority sectors should fully implement their industry-benefits and ambitious potential. But lack of integration in distribution system and the lack of conditions for the system of sales of domestic products inhibit the development otechestvennogo production.

Keywords: animal, crop, production, agro-industrial complex, the gross domestic product, international markets, agriculture, efficiency.

Животноводство в Казахстане представляет собой одну из важнейших отраслей сельского хозяйства и считается основным из направлений в агропромышленном секторе. Объем валовой продукции животноводства в 2015 году составил 1,5 трлн тенге, что в реальном выражении выше уровня 2011 года на 5,1\%. Доля отрасли в структуре валового выпуска продукции сельского хозяйства составила 44,4\%. Общий подъем материального благосостояния населения страны, улучшение условий и полноценности питания, трудящихся в значительной степени определяются состоянием и развитием животноводства. Оно также является важным экономическим рычагом для Казахстана, ведь для сельского населения животноводство это генератор занятости и доходов.

Животноводство обеспечивает население страны такими высокоценными продуктами питания, как мясо, молоко, яйца, масло, сыр, кисломолочные продукты, колбасы, копчености и др.

В соответствии со Стратегией развития до 2020 года, агропромышленный комплекс в числе семи приоритетных секторов должен в полной мере реализовать свои отраслевые преимущества и масштабный потенциал.

В частности, теперь фермеры могут получать субсидии на возмещение $50 \%$ инвестиций на приобретение техники и оборудования, строительство откормочных площадок, хозяйств-репродуктов, птицефабрик, мясокомбинатов, комбикормовых заводов. Ежегодно увеличиваются объемы субсидирования, также совершенствуется механизмы выплаты субсидий, снижаются административные барьеры при оказании государственных услуг в сфере управления сельским хозяйством.

10razkul Dossymova, Taraz State University, Kazakhstan.

2Darya Atasheva, Taraz State University, Kazakhstan.

${ }^{3}$ Nuray Dossymova, Taraz State University, Kazakhstan. 
Вынесены новые кредитные продукты в овцеводстве, коневодстве и молочном животноводстве. Так, АО «Аграрная кредитная корпорация» с 2015 года приступает к реализации трех новых программ, в рамках которых будут выдаваться займы на приобретение овец по программе «Алтын асық», развитие коневодства по программе «Құлан» и строительство инфраструктуры обводнения пастбищ. Кредиты по ставке до 14\% годовых (с учетом субсидирования - от 4\% до 7\% годовых в зависимости от целевого назначения займа) выдаются на приобретение маточного поголовья МРC, лошадей и племенных производителей, а также покупку и ремонт основных средств, пополнение оборотных средств.

Через АО «Фонд финансовой поддержки сельского хозяйства» и АО «Казагрофинанс» будет реализовываться программа кредитования развития семейных ферм в молочном животноводстве «Ырыс». Кредиты на приобретение племенного маточного поголовья КРС молочной породы и приобретение необходимой техники и оборудования можно получить по ставке до 11\% годовых (с учетом субсидирования - до 7\% годовых) до 84 месяцев. Основная цель программы - стимулировать деятельность семейных молочно-товарных ферм, мощностью в 50, 100 и 200 голов, а также повышения продуктивности сельхозживотных и объемов импортоориентированной продукции [1].

В Казахстане снижаются объемы импорта продукции животноводства. Снизились объемы импорта животноводческой продукции, в том числе мяса птицы на $12 \%$, молока на $3 \%$. В целом, отмечается положительная динамика увеличения численности скота и птицы в агроформированиях. Так, рост поголовья крупного рогатого скота составил $12 \%$, и поголовье достигло 1,8 млн голов, овец - на 7\%, лошадей - на $12 \%$, птицы - на $0,1 \%$.

В крестьянских и фермерских хозяйствах за последние 2 года поголовье крупного рогатого скота выросло на $20 \%$, в том числе коров - на $26 \%$. Ранее, в 2008-2009 годах прирост составлял 6 и 5\%, соответственно. В настоящее время доля крупного рогатого скота в агроформированиях составляет $31 \%$ от общего количества, а в личных подсобных хозяйствах $69 \%[2]$.

Объемы производства животноводческой продукции в агроформированиях растут быстрее, чем в среднем по отрасли.

По итогам 2015 года, производство мяса по сравнению с аналогичным периодом прошлого года увеличилось на 2,3 процента, молока - на $2,2 \%$, яиц - на 13,8 \%. Значительно возрастает производство продукции в агроформированиях. Объем производства мяса увеличился на 5 процентов, молока - на 15\%, яиц - на 19\%».

По сравнению с прошлым годом увеличилось и поголовье скота, и объемы переработки продукции животноводства. В среднем по республике перерабатывается 40\% произведенного молока, 33 процента мяса. На рынке молочных продуктов за последние 4 года доля импорта уменьшилась на $16 \%$. А доля импортного мяса на внутреннем рынке уменьшилась на $13 \%$.

Рост переработки животноводческой продукции сдерживается 
недостатком качественного сырья. Например, загрузка мясоперерабатывающих предприятий составляет 86 процентов, при этом большая часть импорта мяса приходится на переработанную продукцию [3].

Более низкую конкурентоспособность отечественной продукции перед импортной продукцией можно поделить на два блока.

Первый блок - это проблемы производственного характера. В частности: относительно низкая продуктивность производства; неудовлетворительное качество производимого сырья, как правило, непригодного к промышленной переработке; сезонность производства и неравномерное поступление на перерабатывающие предприятия сырья в течение года, ввиду большой концентрации производства в личных подсобных хозяйствах, в которых невозможно экономическиэффективное интенсивное производство и внедрение новых технологий; высокий уровень износа активной части основных промышленнопроизводственных фондов пищевой и перерабатывающей промышленности, всё это, в конечном счете, ведет к увеличению себестоимости готовой продукции и ее неконкурентоспособности на рынке.

Также следует отметить, что большая часть импорта приходится на продукцию, произведенную в России и Белоруссии, где существуют более благоприятные природно-климатические условия, а также высокий уровень государственной поддержки и ввиду наличия определенных обязательств в условиях функционирования ЕАЭС отсутствует возможность применения мер тарифного и нетарифного регулирования внутреннего рынка.

Кроме того, существующая статистика по торговле между странами ЕАЭС зачастую некорректно отражает фактический товарооборот, что затрудняет отражение реальной картины и принятие правильных решений.

Второй блок - это все вопросы, связанные со сбытом продукции.

Анализ показывает, что основной причиной высокой доли импорта во внутреннем потреблении является недостаточная защита внутреннего рынка от скрытого демпинга, отсутствие практического применения системы контроля за соблюдением законодательства в области технического регулирования и большое наличие на рынке фальсифицированной продукции.

Имеющаяся сырьевая база не обеспечивает равномерные поставки качественного сырья в течении года из-за неразвитости торговологистической системы, практически отсутствуют объекты по предпродажной подготовке товара (мойка, фасовка, сушка, калибровка и транспортировка и т.д). В целом недостаточный уровень интеграции в систему сбыта и отсутствие условий для системного сбыта отечественной продукции сдерживают развитие отечесвтенного производства. Кроме того, в целом общее состояние недостаточного развития инфраструктуры снижает привлекательность жизни на селе и препятствует развитию агропромышленного комплекса. 
References:

[1] http://agroinfo.kz/Информационно-рекламная аграрная газета 15.01.2016 г.

[2] www.millioner.kz

[3] http://inform.kz/ 


\section{SIMPLIFIED TAXATION SMALL AND MEDIUM BUSINESS IN UKRAINE AND WAYS TO IMPROVE}

\section{A. Abramova ${ }^{1}$}

\section{Abstract}

The article is presented the role and importance of SMEs in the economic growth and expanded reproduction. There are indicators analyzed income single tax to the state budget. Presented ways to improve the simplified tax system for small and medium business in Ukraine.

Keywords: small and medium business, tax, tax system, flat tax, tax reform.

В современных условиях развития экономики Украины залогом успешного развития государства является наличие и оптимальное сочетание предприятий различных форм собственности и организационных форм. Вместе с тем, актуальными остаются вопросы создания благоприятных организационно-правовых условий функционирования бизнеса, как ведущего сектора не только национальной экономики, оптимально решает вопросы организации эффективного национального производства, стимулирует экономическую конкуренцию, способствует структурной перестройке экономики и создает условия для формирования нового социального слоя - предпринимателей-собственников, которые обеспечивают стабильность общества.

Для достижения таких результатов экономиками развитых странах применяются различные налоговые рычаги стимулирования развития малого и среднего бизнеса. В Украине, наряду с общей системой налогообложения, существует упрощенная система налогообложения бизнеса, которую применяет $51 \%$ всех субъектов малого и среднего бизнеса и $50 \%$ занятых в данной сфере.

Именно поэтому на этот экономический сектор необходимо ориентировать адекватную его потребностей и возможностей налоговую политику, котороя должна подчеркнуть и реализовать его социальную значимость. Только в таком случае налоговая политика станет органичной и неотъемлемой составляющей общей государственной политики развития малого и среднего бизнеса.

Среди ученых, исследующих вопросы упрощенной системы налогообложения бизнеса в Украине следует выделить: Ю.Б. Иванова, А.М. Тищенко, А.М. Соколовский. Однако, данный вопрос остается актуальным, поскольку налоговое законодательство малого и среднего бизнеса постоянно меняется и требует анализа и поиска путей его совершенствования.

Развитие субъектов бизнеса в Украине является фактором устойчивого

1Alla Abramova, Candidate of Economic Sciences, Associate Professor, Yuriy Fedkovych Chernivtsi National University, Ukraine. 
экономического развития, без которого экономика не может функционировать. Действующее в Украине налоговое законодательство постоянно меняется в связи с вступлением в силу Налогового Кодекса Украины [1] и с последующими изменениями 24 декабря 2015 [2]. В результате постоянно совершенствуется налоговая система Украины, а вместе с ней и системы налогообложения бизнеса. Это свидетельствует о введении эффективных взаимоотношений между органами государственной власти и субъектами бизнеса, наряду с формированием доходной части бюджета, обеспечивающих стимулирование и развитие сфер предпринимательской деятельности.

Успех от осуществления предпринимательской деятельности зависит от многих факторов. Условием достижения высокой ее результативности является правильный выбор системы налогообложения и организации налогового учета. Субъекты бизнеса используют возможность выбора альтернативной схемы налогообложения, которая сейчас представлена упрощенной системе налогообложения учета и отчетности.

Для выяснения роли и значения упрощенной системы налогообложения проведем оценку эффективности ее функционирования в Украине путем выявления социально-экономических последствий. Такую оценку необходимо проводить с точки зрения субъектов бизнеса государства в соответствии с целью, которую ставит каждый участник. Вместе с тем, основной целью бизнеса является получение экономического эффекта, тогда как государство, оценивая альтернативную систему налогообложения, имеет цель получить экономический, социальный и фискальный эффект.

Социально-экономическая эффективность упрощенной системы налогообложения проявляется из-за роста объемов реализованной продукции (работ, услуг), роста новых рабочих мест и косвенно влияет на уменьшение выплат из фонда социального страхования на случай безработицы.

Малый бизнес не требует значительных стартовых капиталовложений и при этом обеспечивает быстрый оборот и рост, индивидуализацию и дифференциацию потребительского спроса, ускоренного научно-технического прогресса, роста номенклатуры промышленных товаров и услуг, а также мобильность, которая способствует углублению кооперации и специализации.

В табл. 1 продемонстрирована роль малого и среднего бизнеса в производстве, реализации продукции и в обеспечении рабочих мест [3].

Согласно представленных данных в табл. 1, становится понятным, что в структуре реализованной продукции субъектами бизнеса доля реализованных товаров (работ, услуг) предприятий малого и среднего бизнеса составляет более $60,0 \%$ и имеет тенденцию к росту в 2015 году на $2,7 \%$ и 2,0 \% по сравнению с 2013 и 2014 годами. Такие данные еще раз подтверждают роль и значение исследуемых субъектов предпринимательства в экономическом росте и воспроизводимых отношениях. 
Анализ динамики и структуры показателей хозяйствования малого и среднего бизнеса в Украине за 2013-2015 годы

\begin{tabular}{|c|c|c|c|c|c|}
\hline \multirow{2}{*}{$\begin{array}{c}\text { Наименование } \\
\text { показателя }\end{array}$} & \multirow[t]{2}{*}{2013 год } & \multirow[t]{2}{*}{2014 год } & \multirow[t]{2}{*}{2015 год } & \multicolumn{2}{|c|}{$\begin{array}{c}\text { Отклонение (+, -) отчет- } \\
\text { ного периода к }\end{array}$} \\
\hline & & & & 2013 г. & 2014 г. \\
\hline $\begin{array}{l}\text { Объемы реализован- } \\
\text { ной продукции (работ, } \\
\text { услуг), млн грн. }\end{array}$ & 2617061,8 & 2717194,3 & 3503350,9 & 886289,1 & 786156,6 \\
\hline$\%$ & 60,3 & 61,0 & 63,0 & 2,7 & 2,0 \\
\hline $\begin{array}{l}\text { Количество наемных } \\
\text { работни-ков, тыс. че- } \\
\text { ловек }\end{array}$ & 5895,7 & 5184,9 & 4729,0 & $-1166,7$ & $-455,9$ \\
\hline$\%$ & 71,2 & 73,0 & 73,4 & 2,2 & 0,4 \\
\hline
\end{tabular}

Весомым фактором в защиту малого и среднего бизнеса является то, что данные субъекты являются участниками на рынке труда и обеспечивают новые рабочие места и поддерживают уже существующие. Табл. 1 демонстрирует тот факт, что доля наемных работников малого и среднего бизнеса колеблется от 71,2\% в 2013 году до 73,4\% в 2015 году, однако присутствует негативная динамика количественного уменьшения наемных работников в 2015 году по сравнению с 2013-2014 годами. Этот факт дает возможность утверждать об определяющей роли малого и среднего бизнеса в обеспечение занятости населения Украины.

Важным фактором влияния на развитие бизнеса является неэффективная налоговая политика, которая реализовалась через налоговую систему. Уже доказано, что общая система налогообложения дает высокий фискальный эффект по сравнению с альтернативными системами налогообложения, однако, при росте фискальной нагрузки на субъектов бизнеса происходит их выход в тень, рост безработицы и нарушения гармонизации интересов государства, общества и бизнеса. Именно в связи с необходимостью стимулирования и поддержки субъектов бизнеса в Украине и применяется упрощенная система налогообложения, которая предусматривает уплату единого налога.

Единый налог является элементом налоговых поступлений Сводного бюджета Украины и составляющей ВВП, поэтому для анализа рассмотрим его долю в налоговых поступлений сводного бюджета и ВВП (табл. 2) [1].

Из данных, представленных в табл. 2, заметна положительная динамика поступлений налогов и сборов в Сводный бюджет Украины в 20132015 годах. По единому налогу в 2015 году сумма его мобилизации составила 10975,09 млн. грн., что на 3561,84 млн. грн. и 4334,57 млн. грн. больше показателей 2013-2012 годов. Уровень выполнения запланированных показателей в 2015 году составил 118,1\%, в 2014 - 102,7\%, а в 2013-115,6\%. Доля единого налога в объеме налоговых поступлений сводного бюджета в 2015 году составила 2,16\%, что на $0,28 \%$ и $0,14 \%$ больше предыдущих лет. 
Таблица 2

Анализ удельного веса единого налога в поступлениях

Сводного бюджета Украины и ВВП за 2013-2015 годы

\begin{tabular}{|l|c|c|c|c|c|}
\hline $\begin{array}{c}\text { Наименование показа- } \\
\text { теля }\end{array}$ & 2013 год & 2014 год & 2015 год & \multicolumn{2}{|c|}{$\begin{array}{c}\text { Отклонение (+, -) } \\
\text { отчетного периода к }\end{array}$} \\
\cline { 4 - 6 } & & & & 2013 года & 2014 года \\
\hline $\begin{array}{l}\text { Налоговые поступления } \\
\text { Сводного бюджета Укра- } \\
\text { ины, млн. грн. }\end{array}$ & 353968,12 & 367511,97 & 507635,9 & 153667,8 & 140123,9 \\
\hline Единый налог, млн. грн. & 6640,52 & 7413,25 & 10975,09 & 4334,57 & 3561,84 \\
\hline ВВП, млн. грн. & 1454931,4 & 1566728,3 & 1979458 & 524526,6 & 412729,7 \\
\hline $\begin{array}{l}\text { Доля единого налога в } \\
\text { поступлениях бюджета, } \\
\%\end{array}$ & 1,88 & 2,02 & 2,16 & 0,28 & 0,14 \\
\hline $\begin{array}{l}\text { Доля единого налога в } \\
\text { объеме ВВП, \% }\end{array}$ & 0,46 & 0,47 & 0,55 & 0,09 & 0,08 \\
\hline
\end{tabular}

Проводя анализ доли единого налога в объеме ВВП, отметим, что в течение 2013-2015 годов его доля росла: с 0,46\% до 0,55\%, однако увеличение происходит медленнее, чем рост ВВП, что свидетельствует об уменьшении тенизации доходов в сфере бизнеса и о снижении его фискального значения [47]. Налоговая нагрузка на одного плательщика единого налога в среднем составил 4506,02 грн. в 2014 году и 4846,21 грн. - в 2015 [1].

В ходе оценки упрощенной системы налогообложения доказано, что, несмотря на невысокую ее фискальную эффективность по сравнению с общей системой налогообложения, обеспечивается их социально-экономический эффект, который проявляется через рост рабочих мест, объема произведенных товаров и опосредованно влияет на уменьшение выплат из фонда социального страхование на случай безработицы [4].

Изменения, которые произошли в экономике Украины, показали, что действующая упрощенная система налогообложения субъектов бизнеса меняется, имеет место применение финансовых схем уклонения от налогообложения, переориентация деятельности бизнеса с производственной сферы на предоставления услуг. Назрела необходимость совершенствования действующей системы налогообложения бизнеса на основе оценки их эффективности и гармонизации интересов общества, бизнеса и государства.

В связи с этим возникает необходимость разработки системного подхода к налоговой политике, который позволил бы создать налоговую систему, которая была бы не чисто фискальной составляющей, а могла функционально корректировать экономическую систему и реально стимулировать производственную деятельность субъектов налогообложения.

Считаем актуальным для Украины введение стимулов, которые оказывают эффект увеличения доли занятости и вклада в ВВП: предоставление льгот при реинвестировании прибыли, что позволит модернизировать производство и создать рабочие места, применение специальных ди- 
фференцированных ставок в зависимости от сфер деятельности, использование гибкой амортизационной политики, с предоставлением преференций для предприятий, использующих новые технологии, снижение уровня налогообложения фонда заработной платы для предприятий, которые создают дополнительные рабочие места в районах с повышенным безработицей, стимулирование инвестиционной и инновационной деятельности бизнеса, поощрения добросовестных налоговых обязательств.

С целью усиления потенциала упрощенной системы налогообложения целесообразно ввести прогрессивную шкалу ставок налога для физических лиц I и II групп, способствовать повышению прозрачности уплаты налога в соответствии с уровнем получаемого предельного объема дохода, увеличению количества субъектов, которые выбирают упрощенную систему, и в итоге - повышению фискальной эффективности данного налогового режима.

Одним из приоритетных направлений модернизации упрощенной системы налогообложения должно стать совершенствование процедур администрирования: учета плательщиков; контрольно-проверочной работы по правильности исчисления и полноты уплаты налогов в бюджет; работы с должниками; массово-разъяснительной работы с плательщиками, применяющими специальный налоговый режим; прогнозно-аналитической работы по взысканию налогов.

С целью повышения эффективности контрольно-проверочной работы фискальными органами необходимо усилить контроль в части проверки реальных объемов доходов плательщиков единого налога за отчетный период для предотвращения уклонения от налогообложения.

Применение регистраторов расчетных операций субъектами бизнеса будет способствовать предотвращению искусственного уменьшения объемов доходов плательщиков единого налога, оплата работы или услуги которых будет осуществляться через сети терминалов самообслуживания; повышению уровня налоговых поступлений в местные бюджеты за счет увеличения налогооблагаемой базы; повышению контроля за оборотом наличных средств, предотвращению отмывания и легализации денежных средств, полученных незаконным путем; повышению защищенности прав потребителей при оплате работ, услуг.

Одной из основных задач должно стать снижение ставки единого взноса, стимулировать процессы легализации заработных плат наемных работников.

В рамках совершенствования системы электронной отчетности и внедрение мероприятий массово-разъяснительной работы для плательщиков единого налога необходимо создать индивидуальные аккаунты для каждого плательщика информации об уплаченных налогах и налоговую историю взаимоотношений с фискальным органом (копии регистрационных документов, наличие или отсутствие налогового долга на дату) предоставлять услуги о подтверждении получения фискальной службой налоговых декларации и отчетов в электронном виде с помощью сообщения на электронную почту, или СМС - сообщение и тому подобное. 
Выводы. Субъекты малого и среднего бизнеса в современных условиях хозяйствования является основой рынка и основой структурных изменений в экономике. Однако, на государственном уровне не в полной мере обеспечивается достаточная их поддержка, особенно в сфере налогообложения. Общая система налогообложения слишком сложная, а упрощенная - является единственным оптимальным вариантом, который тоже имеет ряд недостатков. Для того, чтобы их ликвидировать необходимо внести предложенные выше изменения в процедуры администрирования единого налога, которые смогут обеспечить стабильность и развитие упрощенной системы налогообложения, учета и отчетности субъектов малого и среднего бизнеса.

References:

[1] Официальный сайт Государственной фискальной службы Украины [Электронный ресурс]. - Режим доступа: http: // sfs.gov.ua.

[2] О внесении изменений в Налоговый кодекс Украины и некоторые законодательные акты Украины относительно обеспечения сбалансированности бюджетных поступлений в 2016 году: Закон Украины от 24 декабря 2015 № 909-VIII.

[3] Официальный сайт Государственной службы статистики Украины [Электронный ресурс]. - Режим доступа: http: // www.ukrstat.gov.ua.

[4] Дробязко С.И., Козырь Т.Н., Холод С.Б. Учет и налогообложение предприятий малого бизнеса: учеб. пособие / под. ред. П. И. Атамас. -М.: Центр учебной литературы, 2014. 416 с. 


\title{
PUBLIC FINANCE MANAGEMENT IN GEORGIA
}

\author{
M. Chelidze1, G. Gelitashvili ${ }^{2}$ \\ DOI: http://doi.org/10.15350/L_26/9/2
}

\begin{abstract}
After Georgia experienced transition to market relations, the financial management system has radically changed. In addition to the Ministry of Finance, other important organizational structures for management of finance are State Audit Office, independent audit financial control offices and so forth.

Within the public finance management reform, the activities planned in the direction of budgeting ensure effective management and transparency of public finance, mobilization of the resources required for implementation of the planned policy with the purpose to develop various sectors, at the same time maintaining fiscal stability; and in parallel with fulfilment of social obligations, implementation of the fiscal policy supporting economic growth.
\end{abstract}

Keywords: Public finance management; Public finance management reform; Effective management and transparency of public finance; Fiscal stability; Maintenance of fiscal discipline.

Centralized budgeting system was replaced by the new budgeting system, which was based on the underlying principle of real independence of different level budgets and their equality. Here, we mean generation of revenues on its own and/or through regulatory duties and freedom of expenditure (within the law). In addition, new relationships and obligations were formed - state budget makes transfers to the budgets of autonomous republics and local budgets.

In Georgia, Management of Finance is carried out by the Ministry of Finance of Georgia based on the Constitution of Georgia and the respective laws adopted by the Parliament. Specifically, the Ministry of Finance uses the Constitution of Georgia, international agreements and arrangements, the Law of Georgia on the Structure, Authority and Rules of Operation of the Government of Georgia", Budgetary Code of Georgia, Tax Code of Georgia, other legislative acts, normative acts of the President of Georgia, legal acts of the Government of Georgia and Prime-Minister of Georgia, statute of the Ministry and other legal acts as a guide for its operations.

Ministry of Finance of Georgia is a central executive government agency, which is engaged in public administration of finance, budgeting and taxation, ensures development and compliance with the budgeting, tax and accounting legislation at the territory of Georgia, carries out preventive operative-investigatory

1Medea Chelidze, Candidate of Economic Sciences, Associate Professor, Georgian Technical University, Georgia.

${ }^{2}$ Goga Gelitashvili, Student, Georgian Technical University, Georgia. 
activities, research and preliminary scrutiny in the field of economic offence.

The purpose, objectives, functions, responsibilities and powers of the Ministry of Finance of Georgia are outlined in the statute of the Ministry ${ }^{1}$, which is approved by the Prime Minister of Georgia. The Ministry is accountable to the government and carries out tasks envisaged in the legislation or assigned by the Government and Prime Minister of Georgia on the ground of the legislation.

The Ministries of the autonomous republics included in the system of Ministry of Finance of Georgia are: Ministry of Finance of Autonomous Republic of Abkhazia and Ministry of Finance and Economy of Autonomous Republic of Adjara.

State sub-departments within the governance of the Ministry of Finance of Georgia are State Treasury and Investigation Service of Ministry of Finance.

Legal entities under Public law within the governance of the Ministry of Finance of Georgia are: Revenue Service; Financial Analytical Service; Service Agency of Ministry of Finance; Academy of the Ministry of Finance.

The Ministry is accountable to the government and carries out tasks envisaged in the legislation or assigned by the Government and Prime Minister of Georgia on the ground of the legislation.

The Ministry develops main directions of fiscal policy and drafts of the respective legislative acts, reviews proposals based on the constitution of Georgia and the law on budgeting system with respect to balancing of the budgets elaborated by the governing authorities of the autonomous republics of Abkhazia and Adjara and other territorial units of Georgia. In addition, the Ministry develops draft of state budget of Georgia, economic norms for formation of the budgets of autonomous republics of Abkhazia and Adjara and other territorial units, and draft volumes of transfers to be made to or received from such budgets, manages state budget to ensure that the budgetary revenues are stable and that the state financial resources are used rationally. Together with the respective local authorities, it performs activities to ensure that the budgets of all levels of the country are fulfilled.

The Ministry is led by the Minister who is appointed by the Prime Minister of Georgia. The Minister of Finance represents the Ministry, governs is activities and makes decisions with respect to the issues within the scope of Ministry's activity; is responsible for performance of the constitution of Georgia, international agreements and arrangements, legislative acts, normative acts of the President of Georgia, resolutions and ordinances of the Government of Georgia, orders of the Prime Minister of Georgia within the scope of the Ministry's governance.

The level of financial management experiences systemic maintenance. It largely depends on the organizational structure of the independent finance office, qualifications, responsibility and discipline of the employees, forms and methods used in the process of financial management.

According to the document by the Government of Georgia ("Public Finance Management Strategy", 2014-2017), the reforms to be carried out in the field of

1 This statute is approved by the resolution \#341 "About approval of statute of the Ministry of Finance of Georgia" dated 17 December 2013 by the Government of Georgia. 
public finance management include the following five priority directions: 1 . Maintenance of fiscal discipline and improvement of fiscal forecasting. 2. Improvement of planning of state finances; 3 . Management, accounting and reporting of the state finances; 4. Internal state control; 5. Development of the state electronic services in public finance management and coordination of donors.

According to the document by the Government of Georgia ("Basic data and directions for 2015-2018"): the government ensures public finance management because, on the one hand, the budget must support increase of expenditures on priority fields and social issues, and on the other hand, the budget must stimulate the economy and at the same time maintain fiscal stability of the country.

The unified standards for planning will be developed which will be related to the national, as well as field-related and other sectoral medium-term strategic documents. Medium-term plans will be used as an effective instrument to achieve fiscal stability. With the purpose to stimulate the economy, in addition to increase of the budgetary expenditure, it is also possible to increase budget deficit in the specific period, however it will be maintained at the low level in the medium-term. In the medium and long-term it is important to maintain basic macroeconomic and fiscal indicators which may improve the assessments of ranking companies and make the country attractive from the perspective of the investment climate.

The direction of macroeconomic analysis and forecasting of the Ministry of Finance will be improved. With the purpose to improve the budget planning process, the process of medium-term forecasting of tax revenues of state and consolidated budget will be improved; the forecasting will be broadened in order to cover economic sectors broadly; time frame of forecasting will increase which will increase the opportunity of long-term planning in fiscal sector.

During formation of the state debt, stability of the debt portfolio will be ensured. The loans will be attracted with the best terms, based on the necessity. The need to develop local securities market and support economic activity will be taken into consideration within this process.

Further work will be carried out in the direction of introduction of program budget and improvement of the respective methodology, including, development of the methodological guidance for spending entities which will assist them in effective management of the internal process of program budget preparation.

Budgeting oriented on results will be fully implemented. Mechanisms of representation of the programs and sub-programs implemented by the budget, as well as their expected outcomes will approach the internationally acceptable standards. Further work will be carried out to increase transparency and informative nature of the budget and all interesting and required information will provided to the Georgian citizens in a simple form.

Further work will be carried out to broaden the functional abilities of the electronic budgeting system (e-Budget). The process of elaboration of the budgets of legal entities under public law, autonomous republics and local self-governing units will be included into this system.

The accounts of the legal entities under public law, autonomous republics and local self-governing units will be opened in the unified state treasury system and 
they will be managed through the unified information system of state treasury finance management, which will achieve full and timely reporting of budgets of all levels and operations carried out with the financial resources of legal entities under public law and will improve the quality of accountability.

International accounting standards for public sector will be implemented stage by stage, and once the full compliance is achieved with these standards, financial statements of the government will be published annually, based on accruals method.

At last, the mechanisms for internal, as well as external control and audit will improve in the field of public finance management. With the purpose to improve the budgeting process, effective mechanism for the use of conclusions and recommendations will be provided by the state audit office.

References:

[1] Mosiashvili V., Chelidze M. - Finance, Texbook - Tbilisi, «Dani». 2016.

[2] http://gov.ge/files/423_49307_626772_PAR_Geo_Draft(1).pdf

[3] http://mof.ge/4832

[4] http://mof.ge/4804

[5] http://treasury.ge/4968 


\section{BANKING PRODUCTS AND SERVISES: SCIENTIFIC APPROACH}

\section{A. Zhavoronok ${ }^{1}$}

\section{Abstract}

The article describes theoretical approaches defining the essence concept of «bank operations», «bank services» and «bank product» in terms of academics. Formed own vision of these concepts. Singled classification division banking on traditional and non-traditional. Identified the necessity of introduction new types of banking services to preserve the competitive position of the bank in the market.

Keywords: banking operation, banking services banking products, traditional services, innovative services.

Современный рынок финансовых услуг банков оперирует следующими взаимосвязанными терминами: «банковский продукт», «банковская операция» и «банковская услуга». Следует определить, что в законодательных источниках, научной и учебной литературе по вопросам банковской деятельности в Украине существуют различные методологические подходы к определению сущности и взаимосвязи этих терминов. Прежде всего, это связано с тем, что отдельные банковские операции и услуги взаимосвязаны, предоставляемых клиентам одновременно и в едином пакете, а определение термина «банковский продукт» заимствовано в терминологии маркетинга и не имеет отражение в одном из законодательных документов Украины.

Для того чтобы определить сущность банковской услуги, нужно понять, что же такое услуга вообще, для этого дадим ряд определений:

Услуга - это итоговый результат взаимного сотрудничества клиента и «услугодателя» по удовлетворению потребности клиента.

Предоставление услуги - это деятельность поставщика, необходимая для обеспечения услуги.

В связи с тем, что банки являются субъектами предпринимательства, понятие их продуктов, с одной стороны, должна соответствовать общепризнанным понятием товаров и услуг, а с другой - учитывать особенности банковской деятельности.

Характеристики услуг подразделяются на два вида: характеристики процесса оказания услуги и характеристики самой услуги. Оба вида должны обладать способностью оцениваться. Оценка возможна количественная (измеряемая) и качественная (сравнимая). Характеристики процесса предоставления услуги в основном не определяются потребителем, они служат для обоснования и доказательства того, что характеристики самой

${ }^{1}$ Artur Zhavoronok, Assistant Professor, Yuriy Fedkovych Chernivtsi National University, Ukraine. 
услуги будут обеспечены на заявленном уровне.

Особенности банковского продукта по сравнению с другими продуктами материальной сферы производства таковы: банковские продукты не приобретают непосредственно материального воплощения в традиционном понимании; отношения с банком имеют преимущественно долгосрочный характер; неразрывность процесса производства и использования банковского продукта; оперирования с деньгами в разных формах: наличными, безналичными деньгами.

Современные экономисты не акцентируют внимание на принципиальных различиях между услугами и банковской операцией и обобщают или даже отождествляют их. В западной литературе господствует расширенный подход к трактовке банковских услуг, когда под ними понимают любой вид деятельности банков, она характеризует деятельность банка охватывающих все стороны деятельности банка как финансового посредника.

В банковском законодательстве наблюдается подмена понятия «банковская услуга» понятием «банковская операция». В Законе Украины «0 банках и банковской деятельности» [1] в ст. 47 «Банковские операции», которая дает перечень возможных действий банка на рынке, приводятся понятия «операции» и «соглашения», среди которых услуги отдельно не выделяются. Национальный банк Украины, когда лицензирует коммерческие банки и выдает им письменные разрешения, также приводит банковские операции и услуги единым списком, объединяя их под названием «операции».

Несколько иначе подходит к рассмотрению этого вопроса А.В. Дзюблук. Он пешее, что банковский продукт «имеет двоякое выражение - с одной стороны, это предоставление различного рода услуг путем проведения активных, пассивных и комиссионно-посреднических операций, а с другой это создание безналичных платежных средств, является результатом тех же операций. Услуги - это конечный результат, готовый продукт банка, тогда как операции - это своего рода производственный процесс» [6, с. 84].

Жуков Е.Ф. в книге «Менеджмент и маркетинг в банках» предлагает следующие определения этих понятий: «Банковский продукт - это конкретный банковский документ (или свидетельство), который производится банком для обслуживания клиента и проведения операций. Это может быть чек, вексель, банковский процент. Банковская услуга банковскими операциями по обслуживанию клиента». В приведенном подходе понятие банковского продукта очень узок. Оно сводится к техническим расчетных документов типа платежного поручения, обедняет сущность и роль банковской деятельности и продукта как ее результата [7, с. 43].

Все упомянутые авторы рассматривают понятие банковской операции и услуги с позиции субъектов отношений - банка и клиентов, и по сути, отождествляют их.

Есть и другие мнения по этой проблематике, которые принципиально отличаются от предыдущих. Отдельные отечественные ученые считают целесообразным отделять услуги банков от их операций, рассматривая 
первые и вторые как два вида деятельности в корне отличные друг от друга. Так, в книге «Введение к банковскому делу» под редакцией Савлука М.И. [10, с. 128] деятельность коммерческих банков делится на три вида: активные операции, пассивные операции, услуги. В таком подходе услуги банков уже отделены от операций и выступают как самостоятельная составляющая продуктов банка.

По мнению Головина Ю.В., «банковская услуга - это совокупность операций, представляющий законченный комплекс услуг, удовлетворяющих любую потребность клиента» [5, с. 250]. В целом определение банковских услуг отечественными учеными сводится к банковским операциям, которые банки выполняют по поручению клиентов. В свою очередь, А.Ю. Викулин на основе действующего законодательства определяет банковские операции как систематически проводятся операции, осуществляемые банками в силу законодательно закрепленной правоспособности, объектами которых выступают деньги, ценные бумаги, драгоценные металлы, драгоценные природные камни [3, с. 56].

Итак, банковскую операцию можно определить как совокупность действий банковского работника, завершается достижением какого-либо результата, необходимого банка или его клиенту. Банковская услуга - технологически взаимосвязанная совокупность банковских операций, которые реализуются банком клиенту на договорной основе и направленных на удовлетворение потребностей клиента в банковском обслуживании.

Исходя из этого, банковский продукт - это банковская услуга, которая удовлетворяет существующие стандартные потребности клиента банка и реализуется на рынке с целью получения дохода. Банковский продукт, в отличие от операции и услуги, обладает индивидуальными особенностями.

Продиктована современными экономическими условиями необходимость создания эффективно функционирующей системы контроля качества банковских услуг, логически обусловливает необходимость развития и внедрения в практику банковского дела самых современных форм услуг и способов их продвижения.

Несомненно, клиенту важно такое свойство как качество банковской услуги, которое можно определить как средство дифференциации клиентской базы, средство привлечения клиента, средство удержания клиента, средство воспитания клиента, средство воспитания. В зависимости от качества банковской услуги ее стоимость может существенно меняться, как в меньшую, так и в большую сторону. В этом смысле для клиента важно, что банковская услуга обладает нужными для него характеристиками и сможет в конечном итоге удовлетворить его потребности. Объектом потребления могут быть банковские услуги - различные по порядку использования, условиям предоставления и назначению. Одна и та же банковская услуга одновременно может обладать множеством различных качеств и быть пригодной для различных вариантов использования, так, например, банковский кредит имеет такие свойства, как платность, срочность, возвратность и т.д., а способов использования банковского кредита настолько 
много, что подсчитать их вряд ли удастся. В свою очередь, совокупность свойств, присущих отдельной банковской услуге, выделяет ее из множества аналогичных банковских услуг, и поэтому качество банковской услуги - характеристика способностей удовлетворять ту или иную потребность, а сама банковская услуга представляет собой ни что иное, как совокупность полезных свойств. Эта совокупность делает банковскую услугу товаром.

Неосязаемость услуг означает невозможность материального их ощущения, увидеть и оценить их до момента получения результатов их предоставления. Главной и ключевой характеристикой банковской услуги является ее эффективность, то есть, конкретная выгода и польза, получаемые потребителем от банковской услуги [8, с. 211].

На этапе продвижения и сбыта банковской продукции (услуг) используются такие способы стимулирования и рекламы, которые повышают степень привлекательности банковских услуг, получение взаимной выгоды при предоставлении банковских услуг, привлечения к рекламе организаций, имеющих солидный статус (известные западные фирмы, правительственные структуры, уполномоченный банк, первичный дилер на рынке ГКО / ОФЗ и т.П.)

Изменчивость качества и неотделимость услуг от квалификации людей требует постоянного обучения персонала. Служащие банка должны иметь опыт работы не только с основными видами банковских операций, но и хорошо знать психологию взаимоотношений людей. Важное значение имеют интерьер банка, освещение, офисная мебель и стиль, цветы и другие внешние элементы, создающие визуальный эффект качества предлагаемых услуг.

Решение о базовом номенклатуре (перечне) банковских услуг принимается на этапе создания банка (универсальный или специализированный), определении его миссии. Перечень базовых услуг, предлагаемых украинскими кредитными организациями, в основном одинаков, поэтому для привлечения большего количества клиентов и формирования общественного мнения и статуса банка используются дополнительные услуги [4, с. 102].

Проведенные многими банками маркетинговые и рекламные кампании часто не приводят к реальному продвижению и развитию услуг, так как носят бессистемный характер. Одной из причин возникновения этой проблемы является и то, что многие банки не корректируют свою деятельность в соответствии с постоянными изменениями внешней среды, своего положения на рынке и финансового состояния. Поэтому часто можно наблюдать ситуацию, когда находится в критическом положении банк продолжает усиленно публиковать рекламу или предоставлять уже не приносят ему дохода услуги.

Другой негативной практикой является несогласованность действий при развитии и продвижении услуг. Для преодоления этого в банках иногда маркетинговые работы координируют специализированные подразделения-службы по продвижению услуг. Но если большой банк может себе позволить содержать следующие подразделения и привлекать в них высокооплачиваемых специалистов, то средние и небольшие банки этого 
себе позволить не могут.

К основным характеристикам банковских услуг, отличающих их от других видов услуг можно отнести следующие:

- договорной характер банковского обслуживания. Предоставление абсолютного большинства банковских услуг предполагает заключение между их производителем и потребителем гражданско-правовых договоров (хотя это может и не до конца осознавать клиентом - как при помещении средств во вклад). Это создает дополнительные сложности (а иногда - психологический барьер) для клиентов;

- договорной характер обслуживания вызывает необходимость обстоятельного разъяснения клиенту содержания банковских услуг и договорных условий их предоставления. Тем самым, маркетинговая деятельность банка приобретает своего рода «просветительский», образовательный характер;

- связь банковских услуг с деньгами. Предоставление основных банковских услуг связано с использованием денег в различных формах и качествах (деньги предприятий, деньги коммерческих банков, деньги Центрального банка в форме наличности, бухгалтерских записей или платежнорасчетных документов). А ко всему, что связано с деньгами, люди относятся с особым вниманием. Это ставит деятельность банка в зависимость от доверия клиентов и требует усилий, направленных на укрепление этого доверия;

- протяженность акта купли-продажи во времени, как и тесная связь с деньгами, придает особое значение доверительного характера взаимоотношений банка и клиента. В самом деле, например, при открытии счета клиент доверяет банку свои деньги и вступает в сделку, течение которой для него изначально неконтролируемо;

- вторичность удовлетворяемых. Как известно, финансовые потребности, которые удовлетворяются банковскими услугами, являются вторичными, производными от первичных производственных и личных потребностей. Что это значит? Разумеется, потребности, удовлетворению которых могут способствовать банковские услуги, весьма разнообразны. Это могут быть как производственные потребности (расширение производства на основе банковского кредита, обеспечение бесперебойного функционирования производства с помощью отлаженной системы расчетов с поставщиками и покупателями), так и личные (начиная от удовлетворения физиологических потребностей за счет доходов от активов, находящихся на депозитных счетах или в трастовом управлении банка, обеспечение безопасности денег и других ценностей посредством хранения их на вкладе или в банковском сейфе, и заканчивая удовлетворением потребности в общественном признании и приобретение социального статуса путем обслуживания в «престижном» банка, пользования «золотой» или «платиновой» кредитной картой и т.д.) [9, с. 65].

Однако все названные потребности не могут быть удовлетворены непосредственно банковскими услугами. Банковские услуги удовлетворяют не первичные производственные и личные потребности, а производные от 
них финансовые потребности. В результате банковские услуги проигрывают в привлекательности материальных благ и услуг, непосредственно удовлетворяет потребности потребителей. Это усложняет задачу финансово-банковских институтов по продвижению своих продуктов на рынке в борьбе за деньги потребителей и требует дополнительных маркетинговых усилий.

Специфика предлагаемых банком услуги требует от потребителей довольно высокой экономической культуры, вызывает необходимость разъяснения содержания услуги клиенту, усиливает значение такого фактора, как доверие клиентов. Ведь клиент, как было сказано выше, доверяя свои деньги банку, вступает в сделку, течение которой он не может контролировать. Итак, неуловимый характер банковской услуги как бы удваивается: это неосязаемые действия с неосязаемыми активами. Таким образом, сущность банковской услуги выражается в экономических отношениях, участниками которых являются банк и его клиент, с помощью и по поводу движения денег, цель банковской услуги - удовлетворение финансовых потребностей и получения прибыли. Оказывается сущность банковской услуги через ее свойства.

Для расширения уже существующих рынков сбыта и завоевания новых банки совершенствуют предоставление имеющихся услуг и внедряют новые, согласовывая их с требованиями рынка и времени. Но для того, чтобы получить новых клиентов, банкам необходимо изучить потребительский спрос, проанализировать рынок конкурентов и составить план действий по продвижению своего товара - маркетинговую стратегию.

В общем выделяют традиционные и нетрадиционные услуги банков.

Традиционные услуги банков - это услуги, занимающие основу деятельности банковского учреждения, и выпивают в силу специфики деятельности банков, и от них он получает наибольшую прибыль. К таким услугам относятся: депозитные; кредитные; расчетные.

Нетрадиционными услугами коммерческих банков называют услуги, которые могут выполнить и другие небанковские учреждения. Поскольку почти все украинские банки являются универсальными, то именно предоставление нетрадиционных услуг может выделять их среди других. К ним относятся: лизинговые услуги; факторинговые услуги; операции с иностранной валютой; консультационные услуги; операции с ценными бумагами; услуги по хранению ценностей; аудиторские услуги; выдача гарантий; трастовые услуги; информационные услуги; другие услуги.

Весьма перспективным направлением развития других банковских услуг является организация своеобразных магазинов, предлагающих своим клиентам различные предметы нумизматического характера. Все эти услуги и составляют систему взаимоотношений банков и его клиентуры. Для расширения уже существующих рынков сбыта и завоевания новых, банки совершенствуют предоставление имеющихся услуг и внедряют новые, согласовывая их с требованиями рынка и времени [2, с. 14].

Итак, банковская услуга - это процесс реализации банковского продукта через систему операций банковского работника, результатом которого 
является удовлетворение потребности клиента банка. Банковская услуга непосредственные связи между банком и клиентом, определяет важность данного понятия.

References:

[1] О банках и банковской деятельности [Электронный ресурс]. Закон Украины, от 7 декабря 2000 № 2121-III, с изменениями и дополнениями / Верховная Рада Украины. Режим доступа: zakon.rada.gov.ua.

[2] Бондарева Ю.Л. Конкуренция на рынке банковских услуг // Банковское дело. 2009. № 1. С. 9-14.

[3] Викулин А.Ю. Определение себестоимости и установление тарифов на банковские услуги // Банковские технологии. 2010. № 4. С. 56-57.

[4] Виноградова Т.М. Банковские операций. Ростов-на-Дону: Феникс, 2001. 379 с.

[5] Головин Ю.В. Банки и банковские услуги в России: вопросы теории и практики. М.: Финансы и статистика, 2004. - 440 с.

[6] Дзюблюк А.В. К вопросу о сущности коммерческого банка и специфику банковского продукта // Вестник Национального банка Украины. 2009. № 6. С. 82-90.

[7] Жуков Е.Ф. Менеджмент и маркетинг в банках. М.: Банки и биржи, 2012. 191 с.

[8] Лютый И. А., Солодка А. А. Банковский маркетинг: учебник для студ. высш. учеб. закл. М.: Центр учебной литературы, 2010. 776 с.

[9] Макарова Л. Система банковского маркетинга. М.: Финстотинформ, 1999.110 с.

[10] Вступление в банковского дела: учеб. пособие / М.И. Савлук, А.М. Мороз, А.М. Коряк. Украинская финансово-банковская школа. Киев: Либра, 1998. 342 с. 


\title{
BIOLOGICAL SCIENCES, BIOMECHANICS
}

\author{
LARVAL TREMATODE INFECTIONS IN FRESHWATER SNAILS \\ VIVIPARUS VIVIPARUS, LYMNAEA STAGNALIS \& PLANORBARIUS \\ CORNEUS FROM THE OREDEZH RIVER AND THE PARK ZONE \\ OF ST. PETERSBURG
}

A. Brusser 1

DOI: http://doi.org/10.15350/L_26/9/3

\section{A bstract}

The article presents generalized data of research of the trematode fauna in mollusks Lymnaea stagnalis, Planorbarius corneus and Viviparus viviparus from the reservoirs of the park zone of St. Petersburg and the Oredezh reservoir for 2014, 2015 and early 2016.

Keywords: Lymnaea stagnalis, Planorbarius corneus, Viviparus viviparus, Trematoda, Mollusca, Snail, Larval Trematoda, Cercariae.

\section{Introduction}

To view the state of health of the population of the country or its individual region can be on the situation with parasitic diseases. The problem of helminthiases as a part of parasitic diseases has not yet received its final solution in any part of the globe.

Parasitic organisms are found in virtually all aquatic and terrestrial ecosystems. By interacting with the organisms of intermediate and definitive hosts, they affect the species composition and bioproductivity of biocenoses.

Among the parasites of humans and animals, the trematode should be specially noted as a unique object of research with a complex life cycle.

To monitor the spread of trematodes, it is necessary to have an idea of the morphology, systematics, biology and ecology of parasites. Life cycle of trematodes consists of several stages, which sometimes take up to four hosts with a change, which is why the complexity of their study is related. The territory of St. Petersburg and the Leningrad region is rich in fresh water bodies, whose beaches are a popular vacation spot for residents of the city in summer. In the region, all the components of the life cycle of trematodes are present, among which mollusks are the first and indispensable intermediate host. In this connection, the study of the trematode fauna in the reservoirs of the recreational zones of St. Petersburg and the Leningrad Region is of great interest.

Since the sexually mature and parthenogenetic generations of trematodes are

${ }^{1}$ Aleksandra Brusser, Master of Science Degree in Biology and Pedagogy; Herzen State Pedagogical University of Russia, St.Petersburg, Russia. 
currently the most studied the actual object of research are cercariae - free-floating larvae of the hermaphrodite generation of trematodes.

The first stage of our work was the study of the species composition of mollusks in the study areas, as well as the identification of the main hosts of trematodes among them and the species of mollusks that was least studied in this matter.

For what it was laid 10 stations: three of them in the park zone of St. Petersburg and seven on the 5-kilometer stretch of the Oredezh River.

Initial collection showed the presence of the following species of mollusks in water bodies (by stations):

Table 1

Malakofauna reservoirs (by stations)

\begin{tabular}{|l|l|}
\hline Stations number & \multicolumn{1}{|c|}{ Molluscs } \\
\hline Station 1 & Lymnaea stagnalis; Planorbarius corneus \\
\hline Station 2 & Viviparus viviparus \\
\hline Station 3 & $\begin{array}{l}\text { Viviparus viviparus; Planorbarius corneus; Lymnaea stagnalis; Anodonta } \\
\text { cygnea }\end{array}$ \\
\hline Station 4 & $\begin{array}{l}\text { Lymnaea stagnalis; Planorbarius corneus; Lymnaea auricularia; Lymnaea } \\
\text { palustris }\end{array}$ \\
\hline Station 5 & Lymnaea stagnalis; Planorbarius corneus \\
\hline Station 6 & Lymnaea stagnalis; Planorbarius corneus; Anodonta cygnea \\
\hline Station 7 & $\begin{array}{l}\text { Lymnaea stagnalis; Planorbarius corneus; Viviparus viviparus; Bithynia ten- } \\
\text { taculata }\end{array}$ \\
\hline Station 8 & Lymnaea stagnalis; Planorbarius corneus \\
\hline Station 9 & $\begin{array}{l}\text { Lymnaea stagnalis; Viviparus viviparus; Bithynia tentaculata; Anodonta cyg- } \\
\text { nea }\end{array}$ \\
\hline Station 10 & Lymnaea stagnalis; Planorbarius corneus \\
\hline
\end{tabular}

Lymnaea stagnalis is a dominant in the reservoirs of the Oredezhsky basin; Subdominant - Planorbarius corneus. Both these species were also present in the investigated reservoirs of the recreational zones of St. Petersburg.

Viviparus viviparus mollusks were found both at the stations of the Oredezh reservoir and in the reservoir of the park zone of St. Petersburg, and in this pond this type of mollusks is an absolute dominant.

The results of previous studies on the parasitofauna of pulmonary mollusks have shown that the main hosts of parasites are lithophilic mollusks that live in the littoral of rivers, and among them - mollusks of the families Lymnaeidae and Planorbidae. As for mollusks of the Oredezh reservoir, there is an advantage over infection in Lymnaea stagnalis and Planorbarius corneus. [12, p.92]

Currently, Viviparus viviparus, as an intermediate host trematode, is one of the least studied, which causes a legitimate interest in its study.

Material and methods

Material for this work was collected from June to August 2014, and from June 2015 to March 2016 in still and slightly flowing water bodies of St. Petersburg and Leningrad region.

A total of 2330 mollusks were examined. Of these: Lymnaea stagnalis - 550 pieces, Planorbarius corneus - 955 pieces and mollusks Viviparus viviparus 825 pieces. It is noteworthy that 5 pieces of Planorbarius corneus collected in March 2016 were found in the pond of the park zone of St. Petersburg for the 
first time in 2 years of searches (in 2014 and 15 years no instances were found).

Mollusks were sampled with a strainer, scoop-net or hand picked on shores. In the laboratory, they were separated into glass containers with tap water (100 $\mathrm{ml})$.

Shedding of cercariae was stimulated by light and heat for 6-8 hours. After checking for infection, and lack of emission of cercariae, the mollusks were deposited in crystallizers or aquariums of different volume with plants and water from the pond. After some time, the mollusks again settled in vessels with clean water for repeated observations. Afterwards, all of the mollusks were dissected to detect larval stages other than cercariae.

The internal morphology of cercariae was documented by drawings with aid of a drawing apparat. Neutral red and Nile blue were used for vital staining; urine solution was used to study the excretory system of cercariae. For measurements, cercariae were fixed in hot $4 \%$ formaldehyde solution. In each case, 10 cercariae were measured.

Cercariae were identified with help of publications of Skryabin (1947-1978), Combes (1980).

Results

After studying the species composition of the mollusks in the study areas and identifying the main hosts of trematodes (Lymnaea stagnalis, Planorbarius corneus) and the least known species of gastropods (Viviparus viviparus), we managed to identify 24 different species of cercariae in them, as well as identify a part Of them completely, the rest - up to the family. Of the 24 species of cercariae found, 22 belong to 6 families; 2 with an unclear systematic position, namely:

Table 2

List of larvae of trematodes found in three investigated species of mollusks

\begin{tabular}{|c|c|c|}
\hline Planorbarius corneus & Lymnaea stagnalis & Viviparus viviparus \\
\hline \multicolumn{3}{|c|}{ Сем. Notocotylidae Lühe, 1909} \\
\hline \multicolumn{3}{|l|}{ Notocotylus sp. I } \\
\hline $\begin{array}{l}\text { Notocotylus attenuatus } \\
\text { (Rudolphi, 1809) Kossack, } \\
1911\end{array}$ & $\begin{array}{l}\text { Notocotylus attenuatus } \\
\text { (Rudolphi, 1809) Kossack, } 1911\end{array}$ & \\
\hline Notocotylus sp. II & Notocotylus sp.II & \\
\hline \multicolumn{3}{|c|}{ Сем. Echinostomatidae Dietz, 1909} \\
\hline $\begin{array}{l}\text { Hypoderaeum conoideum } \\
\text { (Bloch, 1782) Dietz, } 1909\end{array}$ & $\begin{array}{l}\text { Hypoderaeum conoideum } \\
\text { (Bloch, 1782) Dietz, } 1909\end{array}$ & $\begin{array}{l}\text { Hypoderaeum conoideum } \\
\text { (Bloch, 1782) Dietz, } 1909\end{array}$ \\
\hline $\begin{array}{l}\text { Echinostoma revolutum } \\
\text { (Froelich, 1802) Looss, } \\
1899\end{array}$ & $\begin{array}{l}\text { Echinostoma revolutum } \\
\text { (Froelich, 1802) Looss, } 1899\end{array}$ & \\
\hline $\begin{array}{l}\text { Echinoparyphium } \\
\text { recurvatum (Linstow, } \\
\text { 1873) }\end{array}$ & $\begin{array}{l}\text { Echinoparyphium recurvatum } \\
\text { (Linstow, 1873) }\end{array}$ & \\
\hline $\begin{array}{l}\text { Echinoparyphium } \\
\text { aconiatum Dietz, } 1909\end{array}$ & $\begin{array}{l}\text { Echinoparyphium aconiatum } \\
\text { Dietz, } 1909\end{array}$ & $\begin{array}{l}\text { Echinoparyphium aconiatum } \\
\text { Dietz, } 1909\end{array}$ \\
\hline & Cercaria limbifera Seifert, 1926 & \\
\hline \multicolumn{3}{|c|}{ Сем. Strigeidae Railliet, 1919} \\
\hline $\begin{array}{l}\text { Apatemon gracilis } \\
\text { (Rudolphi, 1819) Szidat, } \\
1928\end{array}$ & & \\
\hline
\end{tabular}


Table 2

\begin{tabular}{|l|l|l|}
\hline Planorbarius corneus & \multicolumn{1}{|c|}{ Lymnaea stagnalis } & \multicolumn{1}{c|}{ Viviparus viviparus } \\
\hline & $\begin{array}{l}\text { Apatemon cobitidis cobitidis } \\
\text { (Linstow, 1890) Vojek,1964 }\end{array}$ & \\
\hline & Apatemon sp. & \\
\hline & Cotylurus sp. & \\
\hline & Cem. Diplostomatidae (Poirier,1886) \\
\hline & $\begin{array}{l}\text { Diplostomum spathaceum } \\
\text { (Rudolphi, 1819) Braun,1893 }\end{array}$ & \\
\hline & \multicolumn{2}{|c|}{ Cem. Cyathocotylidae Poche, 1925 } \\
\hline Cercaria sp. I & Cyathocotylus sp. I \\
\hline & Cyathocotylus sp. II \\
\hline & Cyathocotylus sp. III \\
\hline & Cem. Plagiorchidae Luhe,1901 \\
\hline & Plagiorchis sp.I \\
\hline & Plagiorchis sp.II \\
\hline & Plagiorchis sp. III \\
\hline & Plagiorchis sp. IV & \\
\hline & Cercaria sp. II & Furcocercaria sp. \\
\hline & Cercariae an unclear systematic position \\
\hline & \multicolumn{2}{|c|}{ Leucochloridiummorpha sp. } \\
\hline
\end{tabular}

\section{Discussion}

The most vulnerable to infection were the mollusks Lymnaea stagnalis and Viviparus viviparus, in which 13 and 10 species of cercaria of trematodes were found, respectively, of 24, which we detected during the study. There are 9 species of cercariae found in mollusks of Planorbarius corneus.

Moreover, the forebrain mollusk Viviparus viviparus was susceptible to infection in the reservoir of the park zone of St. Petersburg, while the collected and studied mollusks from the Oredezh River during the studies showed no cases of invasion.

In general, the collected and analyzed material on the contamination of mollusks in biotopes, characterized by different hydrobiological and ecological conditions, is consistent with the literature data on the dependence of invertebrate infection of trematodes on their habitat.

The analysis of the material collected by us for 2 consecutive years showed that in the flooded water bodies of the Oreredzh River the locality in the infection of mollusks is distinct and characterized by the repetition of foci at the same points in the reservoir from year to year. We found several such trematodes.

In conclusion, it should be noted that the vast majority of trematodes, which we were able to identify in mollusks, are parasites of birds, especially ducks, which nest in large numbers and feed in the water bodies of St. Petersburg and the suburbs. Due to the fact that ducklings are migratory birds, they are able to spread tremor infections over considerable distances.

According to the extent of invasion, the absolute leader is Leucochloridiummorpha sp., Presumably a representative of the family Leucochloridiidae. It can be assumed that the chemical contamination of the investigated reservoir is 
the reason for the decrease in immune responses in the organisms of freshwater malacofauna and, as a consequence, the high degree of invasiveness of mollusks by the cercariae of trematodes.

Also the extent of invasion is high in representatives of the families Cyathocotylidae, Plagiorchidae, and also Echinostomatidae.

\section{Conclusion}

1. In the study of the Oredezh reservoir, the following species composition of mollusks is established in the study areas: Lymnaea stagnalis; Planorbarius corneus; Lymnaea auricularia; Lymnaea palustris; Anodonta cygnea; Viviparus viviparus; Bithynia tentaculata.

In the study of a reservoir located in the park zone of St. Petersburg, the following mollusks are established: Anodonta cygnea; Viviparus viviparus; Lymnaea stagnalis; Planorbarius corneus.

2. Species - dominant in the reservoirs of the Oredezhsky basin Lymnaea stagnalis, subdominant - Planorbarius corneus. Both these species were also present in the investigated reservoir of the recreational zone of St. Petersburg. Viviparus viviparus mollusks were found both in separate stations of the Oredezh reservoir and in the reservoir of the park zone of St. Petersburg, and in this pond this type of mollusks is an absolute dominant.

3. The main hosts of trematodes among the above-mentioned species of mollusks are Lymnaea stagnalis; Planorbarius corneus. The species of mollusks, Viviparus viviparus, is the least studied in this matter.

4. In the study of mollusks Lymnaea stagnalis, Planorbarius corneus and Viviparus viviparus, 24 species of cirraria of trematodes were found, 22 of which belong to 6 families and 2 to an unclear systematic position, namely:

5 . The vast majority of cercariae of these species at the marita stage are parasites of birds. According to the extent of infestation, the absolute leader is Leucochloridiummorpha sp., And the extent of invasion in representatives of the families Cyathocotylidae, Plagiorchidae, and Echinostomatidae is also high.

\section{Acknowledgements}

The author is deeply grateful to the following persons: Gvozdev Mikhail Alexandrovich, Dobrovolsky Andrey Aleksandrovich - for supervising research work, helping in the definition of cercariae, valuable recommendations and comments. Cheskidova Anastasiia - for help in collecting material.

This research was carried out on the basis of the Department of Biology of Herzen State Pedagogical University of Russia, St. Petersburg, RUSSIA

\section{References:}

[1] Brusser A.V. Unknown cercariae trematodes in mollusks of the Vyritsa reservoir / Herzen readings // Materials of the Interuniversity Conference of Young Scientists. 2016. No. 16. P. 37-41

[2] Brusser A.V. New short-tailed Fourcheccaria Furcocercaria sp. From the freshwater mollusc Viviparus viviparus, Magistrate's Bulletin No. 4 (56) ', Yoshkar-Ola, 2016. P. 4-6.

[3] Brusser A.V. Ecological and epidemiological aspects of diphyllobothriasis in the Leningrad Region, Magistrate's Bulletin №5 (56) I, Yoshkar-Ola, 2016. P. 25-27. 
[4] Brusser A.V. New Cercariae Cercariaeum sp. From the freshwater mollusc Viviparus viviparus, - Magistrate's Bulletin No. 6 (57) I, Yoshkar-Ola, 2016. - P. 4-6.

[5] Combes C. Atlas Mondial des Cercaires. Mémoires du Muséum National d'Histoire Naturelle, Série A, Zoologie, 1980. P. 5-235.

[6] Ginetsinskaya TA Trematodes, their life cycles, biology and evolution. JL: Science, 1968. 411.

[7] Ginetsinskaya TA, Dobrovolsky AA To the fauna of larvae trematodes from freshwater mollusks of the Volga delta. 1. Fourcercercariae (Strigeidae family and Diplostomatidae) // Helminthological collection. Astrakhan, (Tr. Astrakh, Reserve, Issue 6), 1962. S. 45-89.

[8] Ginetsinskaya TA, Dobrovolsky AA To the fauna of larvae of trematodes of freshwater mollusks of the Volga delta. 2. Echinostomatid cercariae (Echinostomatidae) // Collection of parasitological works. Astrakhan, 1964. - P. 64-104. (Tr. Astrakh, Reserve, Issue 9).

[9] Ginetsinskaya TA, Dobrovolsky AA To the fauna of larvae of trematodes of freshwater mollusks of the Volga delta. 3. Fourcerceraria (Cyathocotylidae family) and stilted cercariae (Xiphidiocercariae) // Collection of helminthological works. Astrakhan, 1968. P. 29-95 (Tr. Astrakh, Reserve, issue 11).

[10] Ginetsinskaya TA, Dobrovolsky AA Private parasitology = Parasitic protozoa and flatworms: U.S. for biolog.spets.vuzov / ed. Polyansky Yu.I. Moscow: Higher School, 1978. - P. 212-266.

[11] Gvozdev MA, Stoilova E.B. Seasonal dynamics of infection with Limnaea stagnalis cercariae of the trematodes of the family. Echinistomatidae in the focus of infestation / Uch. Zap. Biol. Fack. OmGPU Vol.2.ch.1, Omsk, 1997. From 58-67.

[12] Gvozdev MA, Stoilova EB, Avanesyan A.V. Ecology of trematodes in reservoirs of the Leningrad Region. // Actual problems of environmental education and environmental protection - Arkhangelsk: ELPA, 1998, C - 92

[13] Gvozdev MA, Gorbunov P.S. Fundamentals of Ecological Epidemiology / St. Petersburg, ed. RGPU them. A.I. Herzen, 2013 - 115 with.

[14] Frolova E.N. Larvae trematodes in mollusks of the lakes of southern Karelia. L.: Science, 1975. - $182 \mathrm{p}$.

[15] Scriabin K.I. Trematodes of animals and humans. Fundamentals of trematodology T.1 - T.21 / Ed. Academy of Sciences of the USSR, M-L, 1947-1963

[16]Scriabin K.I. Trematodes of animals and humans. Fundamentals of trematodology T.22.- T.26 / Nauka, M., 1966-1978 


\title{
TECHNICAL SCIENCE
}

\section{THE ALGORITHM FOR DETERMINING PATHOLOGICAL OBJECTS ON MEDICAL IMAGES}

\author{
A. Zhukov' ${ }^{1}$ R. Tomakova ${ }^{2}$, A. Brezhneva ${ }^{3}$
}

\begin{abstract}
The article is devoted to the implementation of the algorithm for determining pathological objects on medical images.
\end{abstract}

Keywords: image processing, algorithm, filtering, pathological objects.

The widespread use of computer technology and information technology creates the conditions for the automated processing of a large number of images.

The urgency of developing new methods and models for analyzing X-ray images (RS) is determined, first of all, by the increased requirements for the quality and reliability of the systems and medical devices being developed, and the creation of promising information technologies. Therefore, the current problem is the recognition and classification of objects on X-ray images [1, 2].

Within the framework of this project, a software product is developed that allows you to select an object from one image or a set of frames. In the future, the use of this product in various industries, including in medicine, for example, for the analysis of internal organs of man, is supposed.

Currently, a large number of similar software implementations have been developed, which have significant shortcomings [3-5]. However, in order to increase the reliability of diagnosing images, imaging is required, which existing systems do not contain. The basis of recognition should be the comparison of the parts of the image under investigation with the template, and image images of pathological structures can be used as images.

The algorithm of the proposed research method consists in examining the input X-ray image or a set of successive images in one of the image formats. At the output it is necessary to obtain information about the size of pathological formation.

This is achieved by the following sequence of actions:

1. Selecting an object

2. Removing noise

${ }^{1}$ Alexander Zhukov, Southwest State University, Department of fundamental and applied science, student of Software Engineering, Russia.

${ }^{2}$ Rimma Tomakova, Doctor of Technical Sciences, Professor of the Department of Software Engineering, Southwestern State University, Russia.

${ }^{3}$ Alexandra Brezhneva, Candidate of Technical Sciences, Associate Professor, Associate Professor of the Computer Science Department of the Plekhanov Russian Economic University, Moscow, Russia. 


\section{Removing Shadows}

Currently we are at the first stage - the selection of the object.

Selecting an object.

To select an object, there are many different algorithms. The ability of the algorithms to function and produce the correct result depends on various parameters of the input data. In this regard, there is a need to use more than one algorithm to solve the problem. Before us at the current stage of work is the task to identify several of the most effective and correct algorithms from a number of existing algorithms, combine several algorithms to achieve the best result.

Methods for selecting an object can be divided into three main categories:

- Per-pixel.

Process all points of the image independently. Usually at first they build a color model of the background and during the work evaluate how much the current color of the pixel corresponds to it. Such methods usually have a sufficiently high speed of operation, but they are sensitive to noise and do not take into account the boundness of the markup (among most pairs of neighboring pixels either either belong to the background or to the foreground)

- Blocked.

Process independently not individual pixels, but groups of pixels, combined into blocks. In spite of the fact that the use of such methods has made it possible, in some cases, to achieve a high speed of operation, such an approach, even theoretically, does not allow achieving perfect accuracy. To the background or to the foreground, the entire block of pixels applies at once. If the block contains a boundary, then in such areas the boundary of the object is determined to be inaccurate.

- Based on minimizing energy functionality throughout the image. Allows the use of information from the entire image in aggregate, including information on the luminance gradient between neighboring pixels. This approach allows you to take into account, for example, the fact that the boundary of an object more often separates pixels that differ greatly in color than those that are similar in color. By taking into account the pixels in the aggregate, the methods are less sensitive to image noise than per-pixel methods, and give more accuracy than block-based methods. The disadvantage of methods based on the energy functional is the low speed of operation, determined by the low speed of energy minimization methods.

Consider several algorithms from each category.

1. Method of Gaussian mixture (per-pixel).

The Gaussian mixture method is multimodal and allows more accurate description

Statistics of a changing background. The algorithm creates a per-pixel model of the entire scene, which uses separately Gaussian mixes for the background, foreground and shadows. Based on the time of existence and dispersion of each gaussian in the mixture, it is possible to determine which of them belong to the background. Pixels, whose values do not fit into background distributions, are considered to be front-line until a Gaussian appears, allowing them to be accurately related to the background. 
2. Time difference method (per-pixel).

The time difference method separates the foreground from the background by per-pixel subtraction of two or more consecutive frames. It is obvious that time difference methods well define dynamic changes in the scene, but usually can not isolate entirely all homogeneous pixels of one object, which leads to fragmentation of the selected objects (often voids are formed inside them).

3. Adaptive method (refers to the block).

To select the areas of motion, a modification of the method of "subtraction of the background" is used: the foreground model (the moving region (object)) and the background (static background) are built. To reduce the influence of noise and increase the speed of the algorithm, the image is divided into square blocks. Further analysis of the image is reduced to block analysis, where any characteristic of the block (for example, color) is the average value of the pixels included in it. The noise level and background are determined for each unit separately.

4. Background trimming (refers to the minimization of the energy functional throughout the image)

It takes into account the color of the pixel and its contrast with the "neighbors", and also takes into account possible background changes: changes in the dynamics of tumor development, the appearance of new formations. However, the speed of its operation is insufficient for many tasks of determining objects on medical images.

To implement the program of searching for pathological objects on medical images, we used the time difference method, since several images are compared to view the dynamics of tumor development and this method most accurately determines the change in tumor size.

After isolating the object to visualize the dynamics of the development of the tumor, we cross the original image and the result of the algorithm by calculating the area of the tumor.

Calculation of the area of the tumor occurs by per-pixel counting.

The input data and the result of the time difference method are shown in Figures 1 and 2. 


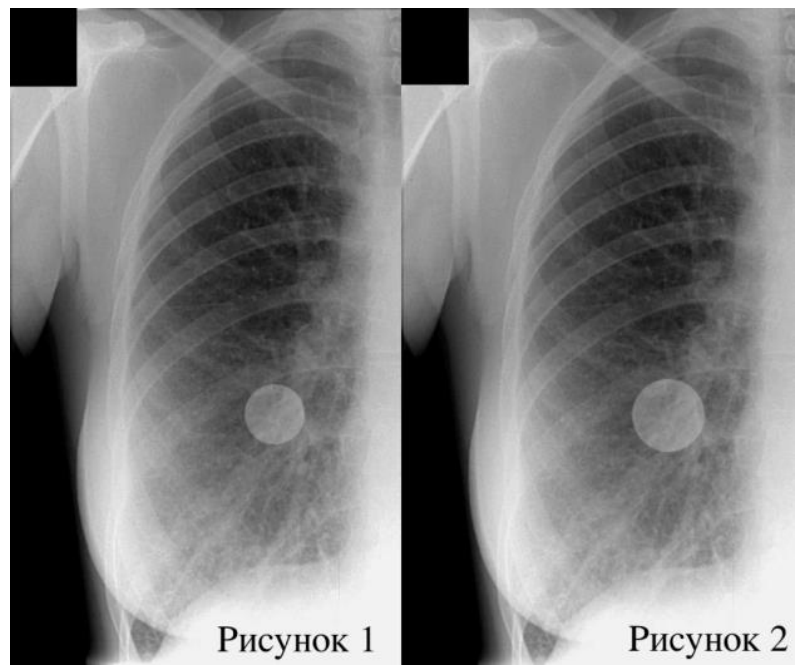

Figure 1. Input images for comparison

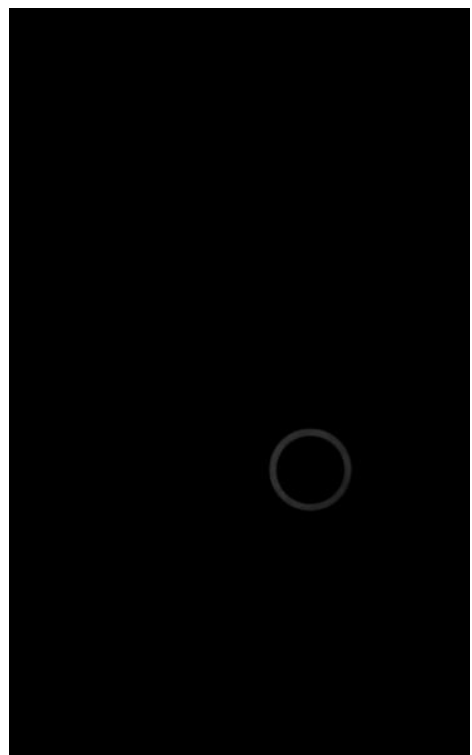

Figure 2. The result of the algorithm

Figure 3 - 5 presents the input data and the result of the algorithm for visualizing changes in the dynamics of tumor development using the example of tumor growth 


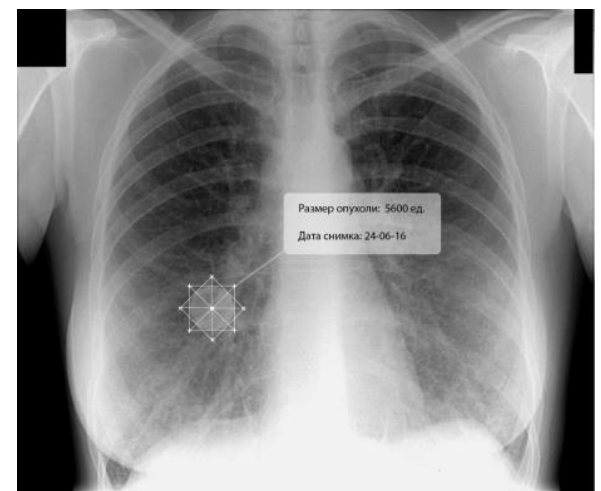

Figure 3. Input images for the visualization algorithm

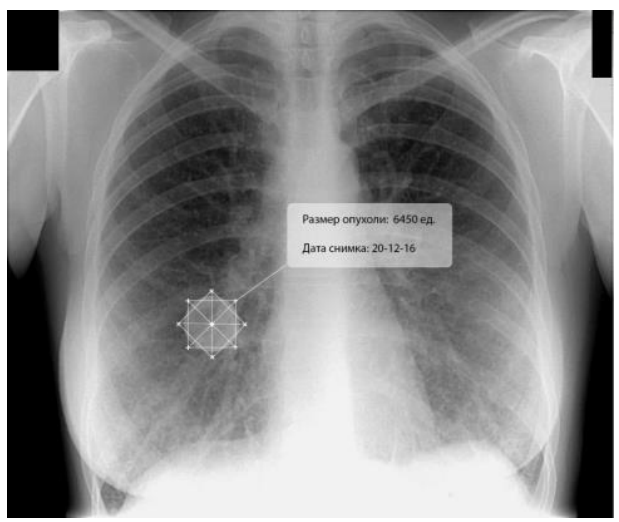

Figure 4. Input images for the visualization algorithm

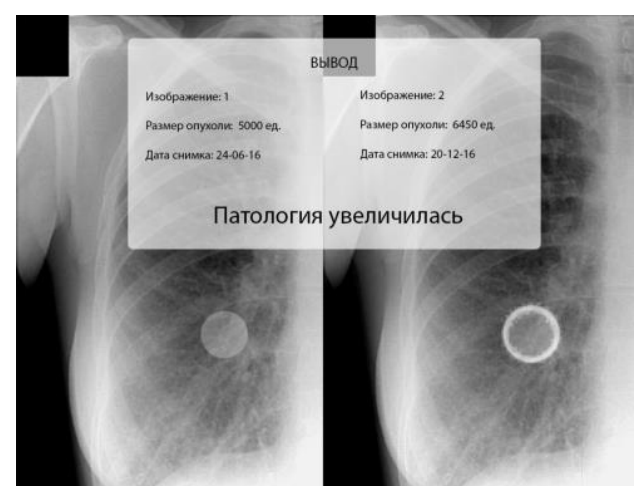

Figure 5. The result of the algorithm for visualization of changes in the dynamics of tumor development 
Conclusions. A program has been developed for isolating pathological objects on medical images, realizing the algorithm for visualizing changes in the dynamics of tumor development, which makes it possible to establish the size of pathological formations as a function of time. In the future it is supposed to develop an automated system for storing images and information about patients.

\section{References:}

[1] The method of classification of radiographs based on the use of global information on their structure / Tomakov, M.V. Tomakov, I.V. Fools // Biomedical radioelectronics. 2016. № 9. - FROM. - C. 45-51.

[2] Tomakova, R.A. Design of a hybrid neural network for the analysis of complex-structured medical images // System analysis and management in biomedical systems. 2011. - T.10. - № 4. - FROM. - C. 916-923.

[3] Neural network decision-making models for diagnostics of lung diseases on the basis of thoracic fluorogram analysis / R.A. Tomakov, M.V. Dyudin, M.V. Tomakov // Biomedical radioelectronics. - 2014. - No. 9. -C.12-15.

[4] Mathematical Support for Recognition and Classification of Complexly Structured Biological Objects. Tomakova, Nasser A.A, O.V. Shatalova // International Journal of Applied and Fundamental Research. - 2012. - №4. - C.48-49.

[5] Comparative analysis of the effectiveness of the method of segmentation of halftone raster images based on the selection of priority directions for processing the boundaries of segments / R.A. Tomakova, S.A. The Philist, V.S. Komkov, S.A. Sorokin // Questions of radio electronics. - 2015. - № 9. - C.133-151.

[6] The Philist, S.A. Analysis of biomedical images using different segmentation methods based on the operators of gradient computation. Philist, E.A. Shashkova, O.V. Shatalova, R A Tomakov // Prospects for the development of information technology. 2011. - № 3-1. - P. 146-150. 


\title{
CHEST X-RAY ANALYSIS USING THE COMBINED CLASSIFIER
}

\author{
R. Tomakova ${ }^{1}$, E. Abolmasova ${ }^{2}$, E. Emelyanova ${ }^{3}$, J. Shepeleva ${ }^{4}$
}

\section{Abstract}

Solving the problems of identifying pathological structures on x-ray digital images of the chest requires high qualification. Therefore, the development of automated systems for diagnosing lung diseases is an urgent scientific and technical task. To classify chest fluorograms, a method of boosting is proposed. Approbation of the classification method was carried out on chest fluorograms (posterior direct projection) with various radiologic syndromes. That is why experimental studies of the method and algorithms for analyzing X-ray images of the chest allow us to recommend them to clinical practice.

Keywords: problems, x-ray digital image, method, analysis, fluorograms chest.

Solving the problems of identifying pathological structures on x-ray digital images of the chest is a great art and embodies the ability to recognize even the smallest changes in the brightness of the RS points, as well as the ability to detect abnormal structures, especially at a low resolution of the image. This requires high qualification and is available to a few people. Therefore, the development of automated systems for diagnosing lung diseases is an urgent scientific and technical task. Nevertheless, more than $90 \%$ of people who have radiological examination showed the result of "tuberculosis", in fact, are healthy. It is well- known Bayes paradox is due to a significant difference in the shares of tuberculosis patients and healthy. Therefore, X-ray diagnostics refers to "weak" classifiers and needs methods aimed at their amplification. X-ray studies, in particular, fluorography, remains one of the most accessible methods of screening diagnostics of pulmonary diseases, so the task of increasing its diagnostic efficiency is at present actual.

To increase the diagnostic efficiency of the "weak" classifiers, the boasting methodology is used, the essence of which is that by classifying the classifiers with low diagnostic efficiency ("weak" classifiers) try to get classifiers with higher diagnostic efficiency - "strong" classifiers. In particular, the boosting algorithm can be implemented by the sequence of training procedures for "weak" classifiers, the selection of the most accurate ones and the compilation of their linear combination.

${ }^{1}$ Rimma Tomakova, department of Software Engineering, South-West State University, Russia.

2Evgenia Abolmasova, student of South-West State University, Russia.

${ }^{3}$ Elena Emelyanova, student of South-West State University, Russia.

4Jeanne Shepeleva, student of South-West State University, Russia. 


$$
C(x)=\left\{\begin{array}{l}
1, \text { если } \sum_{t=1}^{T} a_{t} h_{t}(x) \geq \frac{1}{2} \sum_{t=1}^{T} a_{t} \\
0, \text { иначе, }
\end{array}\right.
$$

Where $\mathrm{C}(\mathrm{x})$ is the final strong classifier, " $\mathrm{T}$ " is the number of weak classifiers inside the strong one, "at" is the weighting coefficient of the t-th weak classifier, ht $(\mathrm{x})$ is the t-th weak classifier with its parameters. In this case, the weighting factors (initially identical) corresponding to all instances of the training sample are modified during the adjustment of the algorithm so that each subsequent weak classifier, in its training, accentuates the images of the training set that the previous classifiers did not cope with [1].

To classify pathological formations on X-ray images, it is necessary to isolate the lung fields, and then break them into segments. The algorithms for automatic extraction of lung fields are described in $[2,3]$. The allocated fields of the lungs are divided into specific departments. Modern medical technologies place high demands on the localization of pathological formations, therefore it is desirable to indicate the dislocation of the pathological focus in a certain segment of the lung.

To look for pathological formations on an X-ray image, scanning is performed on the segments of the image. In the nested loop, a search is made for pathological formations within the scanned section through a classifier derived from the methodology of the bootstrapping analysis.

The classification algorithm is based on the hybrid classification methods described in [4, 5, 6], as well as the Viola-Jones method [1]. The algorithm uses two "weak" classifiers. The idea of selection of weak classifiers is to adapt the window size used in the method of Viola-Jones to a diagnosed lung disease, for example, pneumonia.

During studying the fluorograms of patients with pneumonia, it was found that the pathological fragments of the image are associated with the erosion of the morphological structures of the fluorograms. This process can be detected by two weak classifiers: classifiers which is built on the basis of a two-dimensional Fourier transform, and classifiers on descriptors which is based on the results of approximating the histograms of brightness in a window.

To implement the proposed classifiers at the Department of Biomedical Engineering of South-West State University, software has been created that makes it possible to obtain a set of descriptors intended for constructing image classifiers. The initial interface (main window) of this software, developed in the MATLAB environment, is shown in Figure 1.

Descriptors based on a two-dimensional amplitude Fourier transform are obtained similarly to descriptors based on Haar primitives. The only difference is that if in the method of Viola-Jones all Haar primitives are used with their subsequent elimination depending on the quality of the classification, then the proposed classification algorithm uses a limited set of two-dimensional sinusoids obtained in the entire sliding analysis window. At the same time, the window size from $60 \times 60$ to $4 \times 4$ pixels is optimized.

Among the many features of this software, it is necessary to identify software 
modules that implement spectral methods of image processing. The purpose of developing these modules is to obtain an instrumental environment for classifying images based on Fourier descriptors. Fourier descriptors were determined from the modules of counts of the window two-dimensional Fourier transform on the basis of the advanced concept of constructing the chest $\mathrm{x}$-ray classifier. According to this concept, the roentgenogram of the chest is scanned by windows of variable size. For each window size, a classifier is built, which is referred to as "weak" classifiers. To construct a "weak" classifier, descriptors are used, determined from the histogram of the brightness of the amplitude two-dimensional Fourier spectrum.

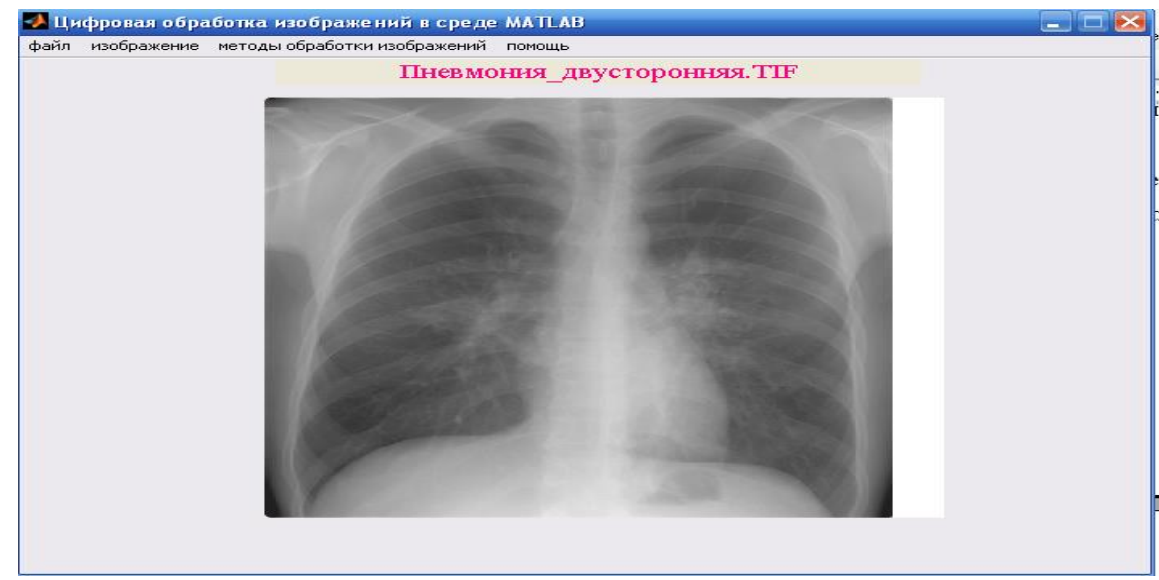

Figure 1. The initial interface of the software for processing biomedical images in the MATLAB environment

In Figure 2, two fragments of the chest fluorogram obtained in windows of the same size are presented as an example. On the right are the corresponding Fourier amplitude spectra. When studying the window spectra of chest fluorograms, the evolution of amplitude Fourier spectra was detected depending on the presence or absence of pathology. These evolutions can be detected through "weak" classifiers, built on the basis of trained neural networks. As information signs, histograms of the brightness of the image of the window amplitude Fourier spectrum were used. Examples of such histograms are shown in Figure 3. For comparison, the histograms of the brightness of the corresponding source images in the window.

Analysis of the images, examples of which are shown in Figures 2 and 3, showed that the shape of the histogram of the brightness of the window spectra showed a higher stability in comparison with the corresponding forms obtained from the original images, which made it possible to form descriptors on its basis, using the technique proposed in [ 5, 7].

"Weak" classifiers are built for each window size. To unite the "weak" classifiers into "strong" classifiers, neural networks of direct propagation are also 
used. Classifiers are trained for each pathology and for each window size.

The second "weak" classifier is based on descriptors obtained as a result of histogram approximation in the analysis window. To understand this method of constructing a "weak" classifier, consider Figure 4.

Figure 4, on the left, shows the analysis window of the fluorogram in the lung field without pathological changes. On the right in this figure is a histogram of brightness in this window.

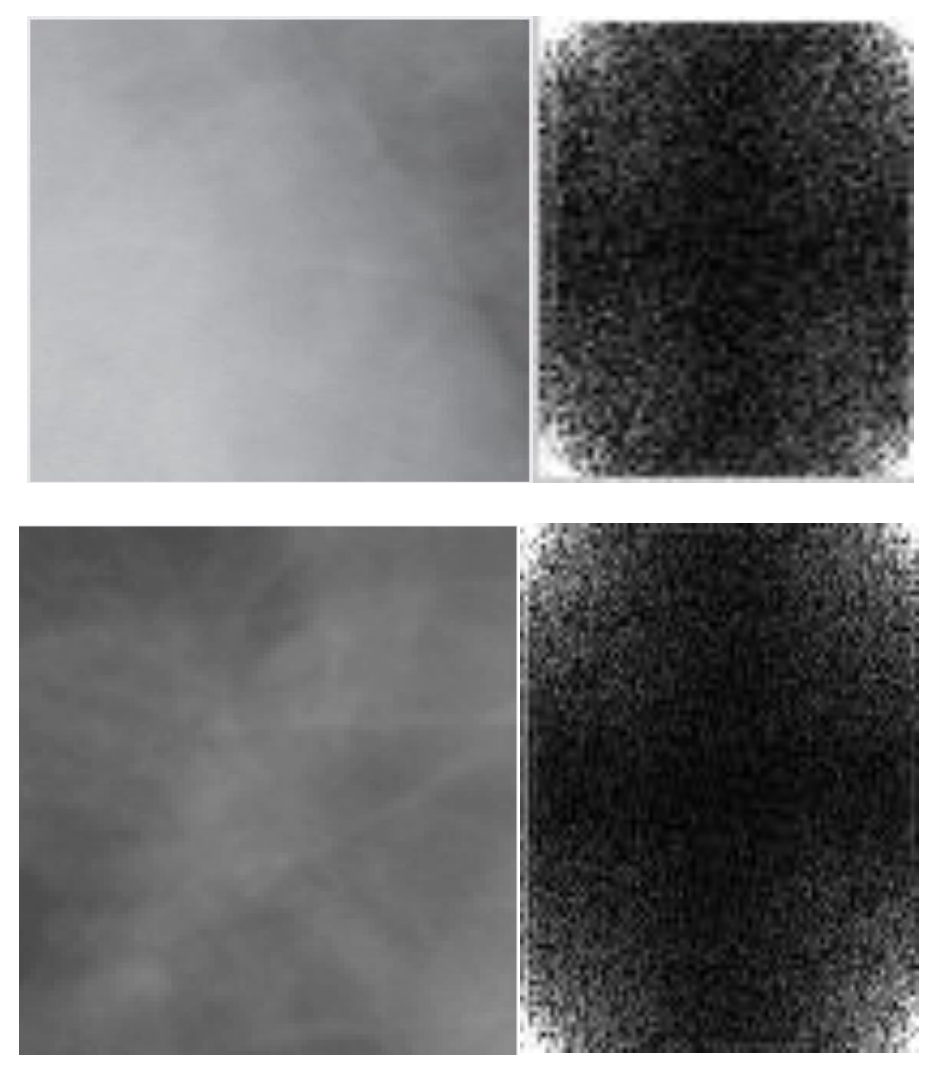

Figure 2. Images of chest fragments of the chest x-ray (left) and their windowed two-dimensional Fourier transforms (right) 


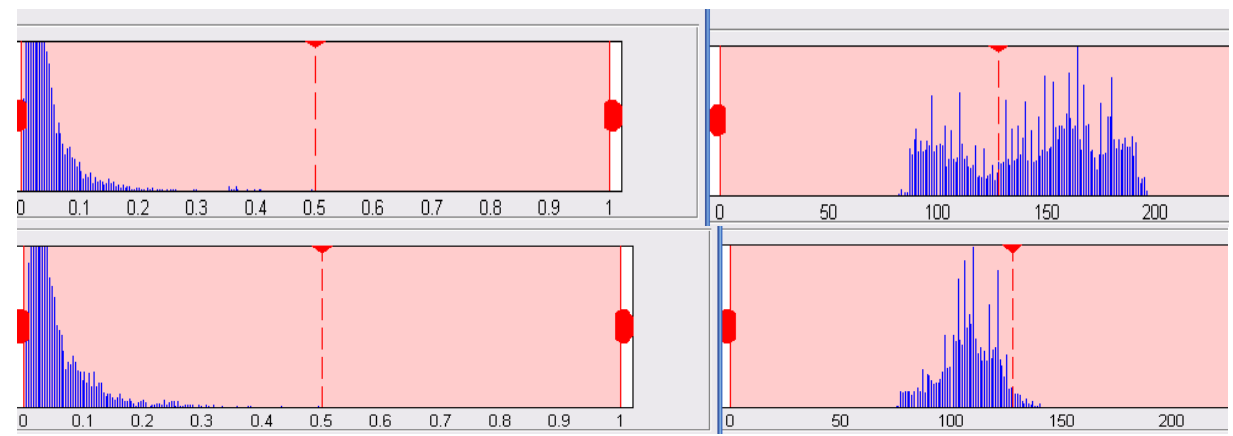

Figure 3. Histograms of the brightness of the window fragments of the chest fluorogram (right) and the histograms of their windowed two-dimensional Fourier amplitude transforms (left)

Analysis of similar histograms of various X-ray photographs showed that, in the absence of pathological changes in the analysis window, histograms have a multimodal shape. Figure 4, b on the left shows the analysis window that simulates pneumonia. For the model of pneumonia, a low-frequency filtering using a two-dimensional Fourier transform was used in the analysis window of a healthy patient's fluorogram. In the presence of low-frequency filtration, the modality of the brightness histogram disappears and the histogram acquires a shape close to a triangular one.
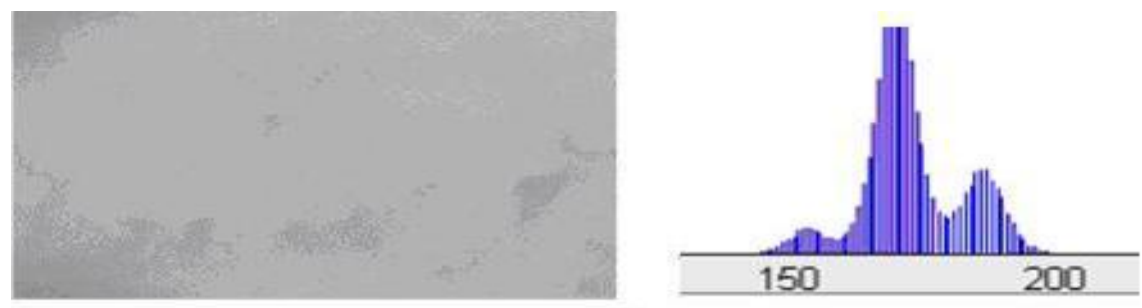

a)
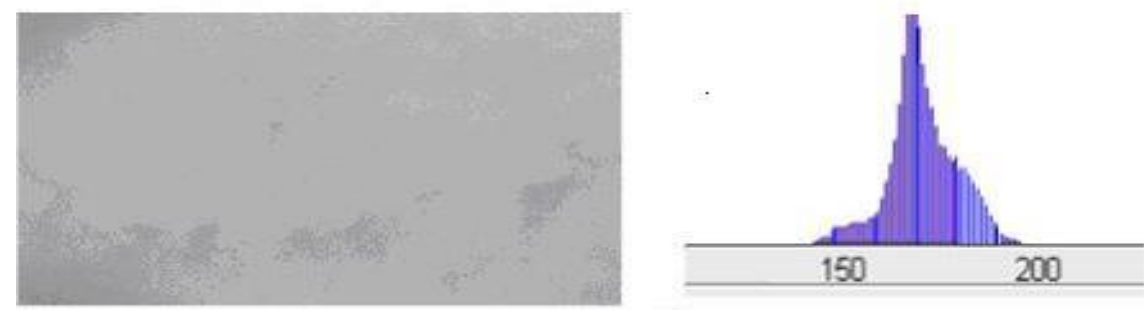

)

Figure 4. Analysis windows and histograms of the brightness of the fluorogram: window without pathology - a; Window model with pathology, obtained as a result of low-frequency filtering of the window without pathology $-b$ 
Figure 5 shows the analysis windows for the same fluorograph image, which has segments classified as pneumonia.

The analysis of the presented images allows to draw a conclusion that in real pathological formations with pneumonia the histogram of brightness in the analysis window acquires a triangular shape. Therefore, the descriptors of the second classifier are formed as primitives that approximate the brightness histograms in the analysis window.
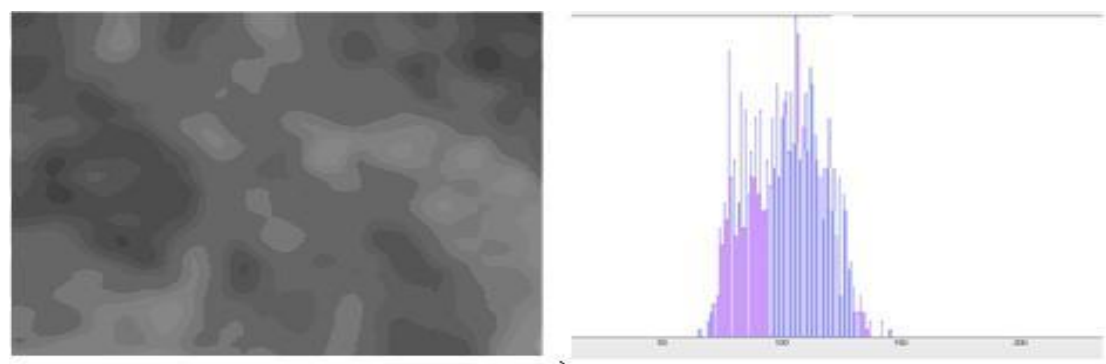

a)
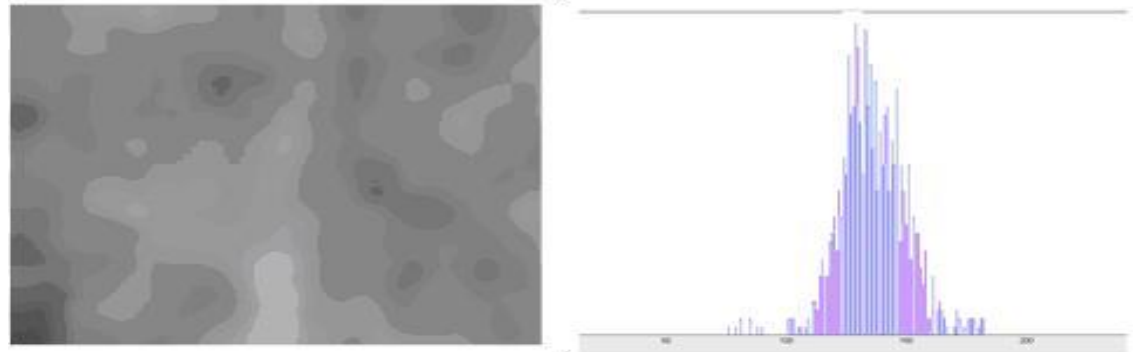

6)

Figure 5. Analysis windows and histogram of brightness of fluorography: window without pathology - a; Window with pneumonia $-b$

"Weak" classifiers 1 and 2 work in a single-size analysis window. The classifier aggregator takes the final decision about the belonging of the fragment in the analysis window to the class under study. The segment belonging to the analysis window is binarized. As the analysis window moves through the image, a binary image is formed.

The real fluorograms with pneumonia before treatment and after treatment by the presented method are shown in Figure 6.

Software that implements the proposed method and algorithms, was tested under various X-ray syndromes, as well as with various structures of neural networks. Analysis of the characteristics of the isolation of the examined pathological segments of the RS image of the chest showed that the proposed method of analysis makes it possible to increase the segmentation efficiency by more than 1.5 times in comparison with the known ones on the same control samples. 

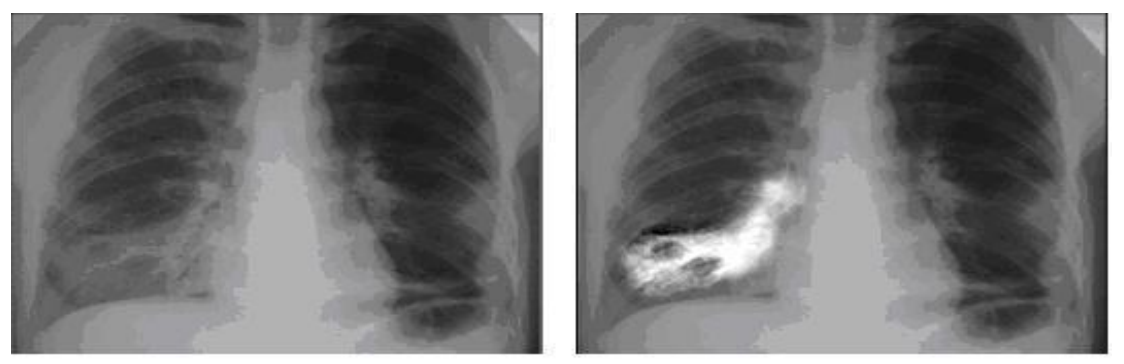

Figure 6. Real fluorographs with pneumonia before treatment and after treatment presented by method

As a result of experimental studies, quantitative results of the diagnostic quality of X-ray syndromes were obtained. For the formation of training and control samples, X-ray images and results of clinical observations of patients from the hospital of the ambulance in Kursk were used. At the same time, 34 fluorograms of patients with pneumonia were studied, characterized by syndromes associated with impaired transparency of lung tissue: "Extensive (total) decrease in the transparency of lung tissue"; "Subtotal darkening"; "Limited blackout." As a control group, fluorograms of fifty patients of the same hospital without pulmonary pathologies were used.

On the diagram (figure 7) the results of the analysis of the conclusions by sex and the criterion of the sick is presented. The latter is important in making a decision for subsequent follow-up and pre-examination in clinical settings if it is revealed that the patient is sick and the program can not specify an accurate diagnosis

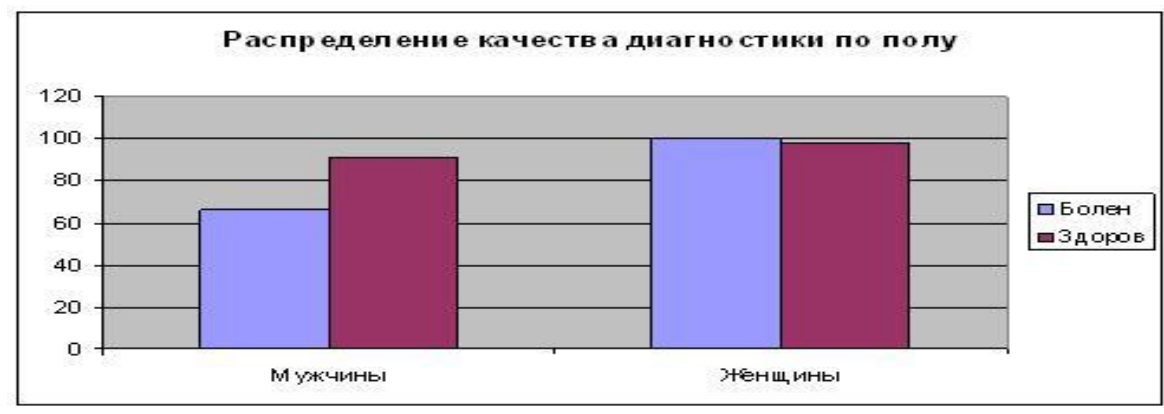

Figure 7. Coincidence of medical reports and AS DZL by criterion is sick - healthy

When carrying out experimental studies, it was found that the conclusion of the program coincides with the doctor's diagnosis: "no pathology was found" in $91 \%$ of cases in men and $97.5 \%$ in women. The coincidence in the conclusions of "pneumonia" is about $66 \%$ in men, $100 \%$ coincidence in women, which indicates the good sensitivity of the decision modules included in the automated system.

Conclusions. To classify chest fluorograms, a method of boosting is proposed. 
The method allows to obtain a combined classifier, which includes two "weak" classifiers and one "strong" classifier. The first "weak" classifier is a classifier built on descriptors formed on the basis of the Viola-Jones method and a twodimensional amplitude Fourier analysis performed in a sliding analysis window. The second classifier uses a classifier built on descriptors formed on the basis of primitives approximating brightness histograms in a sliding analysis window. The descriptors of "weak" classifiers do not depend on the dynamic range of the brightness of the florogram or the difference in dynamic luminance ranges in the analysis windows. Approbation of the classification method was carried out on chest fluorograms (posterior direct projection) with various radiologic syndromes.

That is why experimental studies of the method and algorithms for analyzing $\mathrm{X}$-ray images of the chest allow us to recommend them to clinical practice.

\section{References:}

[1] Akimov A.V. Development and study of image recognition algorithms based on the Viola-Jones method using the technology of computing on Cuda graphics processors. Akimov, A.A. Sirota // Vestnik VSU, Series: Systems Analysis and Information Technology, 2014, No. 3. - P. 105-108.

[2] Dyudin, M.V. Neural network decision-making models for the diagnosis of lung diseases based on the analysis of chest fluorograms / M.V. Dyudin, RA Tomakov, M.V. Tomakov // Biomedical radioelectronics, 2014, №9. - P.12-16.

[3] Dyudin, M.V. A method for isolating and classifying the contours of the lungs on images of thorax fluorograms / M.V. Dyudin, S.A. The Philistine, P.S. Kudryavtsev // High technology. - 2014. - No. 12, v. 15. - P. 25-30.

[4] Tomakova, R.A. Fuzzy neural network technologies for isolating segments with pathological formations and morphological structures on medical images / R.A. Tomakova, A.A. Maslak, N.A. Shvetsova // Biomedical radioelectronics. 2012. № 4. P. 56-62.

[5] The Philist, S.A. Automatic classifiers of complex structured images on the basis of multimethodic technologies of multicriteria choice. Philist, M.V. Dyudin, I.V. Zuev, et al. / Questions of radio electronics. Series "Systems and means of information display and control of special equipment" (SOIU), 2015. Issue 1. - P.130-140.

[6] The Philist, S.A. Universal Network Models for Classification of Biomedical Data. Filist, R.A.Tomakova, Ya Zar Do. // Izvestiya YuSGU. - Kursk: Publishing House of Southwestern University, 2012. - No. 4 (43). - Part 2. - P. 44-50.

[7] Tomakova, R.A. Intellectual technologies of segmentation and classification of biomedical images. Tomakova, S.G. Emelyanov, S.A. The Philistine. - Kursk: South-West. State. University, 2012. - 222s. 


\title{
REGENERATION METHOD STUDY OF USED MOTOR OILS
}

\author{
M.Zh. Almagambetova ${ }^{1}$, A. Dyussenova ${ }^{2}$
}

Abstract

This article refers about regeneration method of used MOTOR OILS. Regeneration and secondary application of used motor oils, which present source base for producing of useful products in proper processing conditions, are actual objectives. In this connection used oils regeneration method has been considered.

Keywords: used motor oils, regeneration, heterocyclic compounds used motor oil.

Одним из источников загрязнения окружающей среды - отработанные моторные и трансмиссионные масла, которые при смене в двигателях и агрегатах автомобилей, тракторов и судов нередко сливают в почву или водоемы. В лучшем случае в автохозяйствах и пунктах базирования судов отработанные масла собирают в специальные емкости, из которых их периодически отбирают и вывозят на нефтебазы для утилизации или регенерации. При сдаче на нефтебазы отработанные моторные и индустриальные масла, как правило, не соответствуют установленным нормам по температуре вспышки.

В основном их принимают как смеси отработанных нефтепродуктов по цене, в 4 раза меньшей, чем цена печного топлива. И низкие закупочные цены не оправдывают расходы, связанные со сбором и доставкой отработанных масел на приемные пункты нефтесбытовых организаций.

Решение экологических проблем, бережное отношение к природным ресурсам и охрана окружающей среды в век бурного развития машин и технологий являются первоочередными задачами всего человечества. Угрожающей компонентой насущной и все усугубляющейся проблемы является загрязнение почв и водоемов отработанными маслами, приводящее к безвозвратным потерям флоры и фауны на земле и в воде [1].

Потребление моторных масел в мире составляет примерно 60 млн.т. в условном топливе. И есть данные только о четвертой части этого количества, сообщающие, что после отработки ресурса масло использовано повторно либо переработано или сожжено.

По нашей стране статистика еще печальнее. За год на территории РК собирается около 1,3 млн. т различных отработанных моторных масел (OMM).

${ }^{1}$ Aynagul Almagambetova, Assistant professor, West Kazakhstan agrarian technical university name Zhangir Khan, Kazakhstan.

${ }^{2}$ Ainagul Dyussenova, Undergraduate, West Kazakhstan agrarian technical university name Zhangir Khan, Kazakhstan. 
Переработке при этом подвергается до 0,25 млн. т, или 15\%, что составляет 3,3\% от общего объема потребления. Для сравнения: в Германии, занимающей первое место в Европе по очистке ОМ, производится сбор и использование около 55 \% всего объема потребленных свежих масел.

Немецкое законодательство в области защиты экологии обязывает производителей масла, чьи производства находятся на территории Германии, добавлять в производимые масла не менее $10 \%$ так называемого refining base oil - восстановленного масла. В некоторых европейских странах существует порядок, когда при сдаче отработанного масла сдающий получает свежее масло со скидкой.

О необходимости сбора и переработки ОМ свидетельствует тот факт, что из примерно 100 т нефти получают только 10 т моторного масла, а при переработке 100 т ОМ можно получить более 80 т уже готового к употреблению продукта [2].

Целью данной работы является использование отработанного масла в производстве. Для достижения цели ставились следующие задачи: физико-химический анализ и очистка отработанного моторного масла.

В процессе эксплуатации моторных масел в них накапливаются продукты окисления. Это асфальтосмолистые соединения, нагар, лаковые отложения и др. Чтобы предотвратить выпадение осадка этих вредных соединений, в масло вносят моюще-диспергирующие присадки, которые удерживают продукты окисления в коллоидном (взвешенном) состоянии.

Значительное снижение эксплуатационных характеристик моторных масел наступает, когда присадки вырабатывают ресурс. В этот период продукты окисления начинают выпадать в осадок, тем самым вызывая усиленный износ двигателя. Такое состояние моторного масла свидетельствует о необходимости срочно его заменить.

Моторное ОМ относится к категории опасных отходов, является источником загрязнения окружающей среды. Его нельзя сливать в мусорные баки, канализацию или на землю.

Из-за присущей вязкости такое масло прилипает ко всему, от песка до оперения птиц. Отработанные масла не растворимы, химически устойчивы и могут содержать токсические химические соединения и тяжелые металлы. В естественных условиях масло разлагается в течение длительного времени. Представьте, что всего 1 л моторного масла может превратить 1000000 л питьевой воды в техническую.

Для основного состава транспортных предприятий тема утилизации ОМ - одна из самых злободневных. Организация и содержание пунктов сбора ОМ, хранение, транспортировка, переработка - все это требует финансовых затрат. В реальности незначительную часть ОМ сжигают, а большую часть все-таки сливают либо на почву, либо в водоемы и канализацию.

А ведь бережно собранное ОМ, без внесения в него дополнительных загрязнений в виде почвенной и воздушной пыли, воды, топлива, моющих жидкостей и жидкостей не нефтяного происхождения, можно использовать после очистки и восстановления в среднефорсированных двигателях 
внутреннего сгорания при умеренных нагрузках, в гидравлических системах машин, в коробках передач и трансмиссиях тракторов и автомобилей при умеренных нагрузках, в ходовой части гусеничных тракторов, а также при консервации техники.

Современные технологии позволяют получать такой объем смазочного масла из 1 л ОМ, для получения которого при прямом производстве тратится 42 л сырой нефти.

Процесс восстановления отработанного моторного масла в современном понимании включает удаление из него коллоидных веществ, кислот, битумных отложений, механических частиц и химического осадка, удаление газов, водного конденсата, придание восстановленному продукту цвета и запаха оригинала.

Однако из существующих и реализованных в настоящее время промышленных процессов восстановления ОМ трудно выделить предпочтительные, все они не лишены как преимуществ, так и изъянов.

В каждом конкретном случае при выборе предлагаемой технологии вторичной переработки ОМ необходимо исходить из анализа работы уже действующих прототипов и очень осторожно браться за внедрение новых предложений.

В зависимости от примененного процесса регенерации получают дветри фракции базовых масел, из которых путем компаундирования и введения присадок получают товарные масла: регенерированные моторные можно использовать как трансмиссионные, гидравлические масла, СОЖ и пластичные смазки, а кроме того, их используют при производстве асфальта.

Обычно при восстановлении в первую очередь механическим путем удаляют свободную воду и твердые частицы. Затем идет теплофизическая фаза - выпаривание, вакуумная перегонка. За этой фазой происходит физико-химическая обработка.

Дело в том, что при фильтрации ОМ наблюдается весьма незначительный эффект очистки за счет присутствия многофункциональных присадок, в составе которых есть моющий компонент.

Окисные соединения, которые под действием присадок находятся в коллоидном мелкодисперсном состоянии, необходимо с помощью коагулянтов несколько увеличить в объеме, тогда масло становится фильтруемым. Исследования доказали, что оптимальное коагулирование осуществляется в случае применения моноэтаноламина.

На следующем этапе регенерируемое масло подвергают микрофильтрации, пропуская его через мембраны, различающиеся как производительностью, так и термической устойчивостью, поскольку традиционным способом увеличения удельной производительности мембран является снижение вязкости жидкости за счет повышения температуры.

Наиболее распространенными являются полимерные мембраны типа МФФК. Они способны отфильтровать около 800 л/( м $\left.^{2} .4\right)$ при диаметре пор 0,07 мкм.

Металлокерамические мембраны типа «ТРУМЕМ» являются самыми 
производительными - при диаметре ячейки 0,07 мкм они пропускают 1000 л/( м $^{2}$.ч). Для самой тонкой очистки применяют мембраны керамические одноканальные со средним диаметром пор 0,03 мкм. Углеродные одноканальные мембраны осуществляют наиболее грубую очистку: у них диаметр пор 0,1 мкм, зато эти мембраны термически устойчивы до $300{ }^{\circ} \mathrm{C}$.

Высшей целью регенерации является получение масел с характеристиками, превосходящими первоначальные свойства продукта, поступившего на восстановление. Это возможно, но для этого кроме вышеперечисленных этапов обработки ОМ требуется применять химические способы регенерации, связанные с использованием сложного оборудования и большими затратами.

Реально же очищенные ОМ обладают достаточным запасом эксплуатационных свойств, обеспечивающих применение в менее нагруженных узлах и агрегатах машин [3,4].

Исходные физико-химические параметры ОММ приведены в табл.1.

Таблица 1

Физико-химические характеристики ОММ

\begin{tabular}{|c|c|c|c|c|}
\hline Наименавание параметров & $\begin{array}{c}\text { Метод } \\
\text { исследования }\end{array}$ & I проба & II проба & III проба \\
\hline 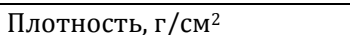 & ГОСТ 3900-85 & 0,864 & 0,854 & 0,849 \\
\hline $\begin{array}{c}\text { Вязкость, } \text { м }^{2} / \mathrm{c} \\
40^{\circ} \mathrm{C} \\
100^{\circ} \mathrm{C} \\
\end{array}$ & ГОСТ 33-2000 & $\begin{array}{c}97,8 \\
93,05 \\
\end{array}$ & $\begin{array}{c}107,7 \\
102,25 \\
\end{array}$ & $\begin{array}{l}81,63 \\
74,46 \\
\end{array}$ \\
\hline Температура вспышки, ${ }^{\circ} \mathrm{C}$ & ГОСТ 4333-87 & 202,3 & 209,3 & 211,3 \\
\hline Содержание воды, мл & ГОСТ 2477 & 0,323 & 0,317 & 0,337 \\
\hline Зольность, г & ГОСТ 1461-75 & 0,93 & 0,909 & 0,860 \\
\hline Механические примесей, г & ГОСТ 6370-83 & 0,6 & 0,44 & 0,8 \\
\hline
\end{tabular}

Асфальто-смолистые вещества (АСВ) нефти и нефтяных остатков представляет собой гетероароматические соединения, которые, кроме углерода и водорода, содержат серу, азот, кислород и металлы, такие, как ванадий, никель, железо, молибден и т.д.

Содержание АСВ в тяжелых нефтяных остатков колеблется в довольно широком диапазоне: от 40 до 60\%.

В зависимости от вида нефти, фракции перегоняющиеся выше 400-450 ${ }^{0} \mathrm{C}$, могут полностью состоять из гетероатомных соединений.

Выделение индивидуальных асфальто-смолистых веществ из тяжелых нефтяных остатков возможно лишь с применением экстрагентов.

В зависимости от экстрагента асфальто-смолистые вещества делятся на следующие группы:

- нейтральные смолы, растворимые в легком бензине (петролейном эфире);

- асфальтены, не растворимые в петролейном эфире, но растворимые в бензоле;

- карбены, частично растворимые только в пиридине и сероуглероде;

- карбоиды - вещества, практически ни в чем не растворимые; 
- асфальтогеновые кислоты и их ангидриды - вещества кислого характера, не растворимые в петролейном эфире, но растворимые в спирте.

На рис.1 приведены фрагменты разных гетероциклических соединений содержащее один, два и три ароматических или гетероароматических кольца [5].

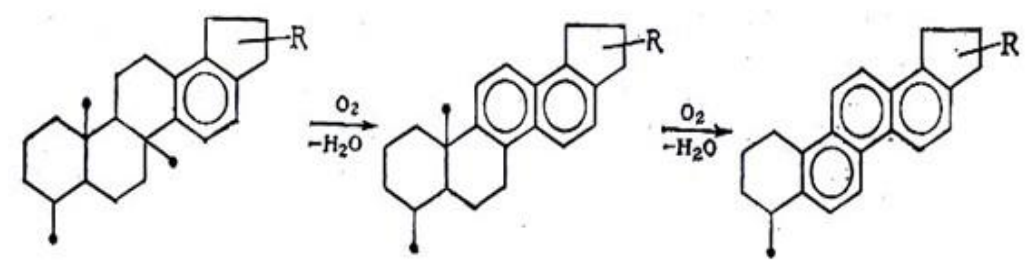

Рис. 1. Фрагменты гетероциклических соединений

Для восстановления эксплуатационных свойств ОММ нами было опробовано разные методы обработки: центрифугирование, кислотно-щелочная очистка, адсорбционная очистка, осаждение коагулянтами.

Наилучшие результаты были получены при использовании композиционных смесей химических реагентов.

В качестве химических реагентов было использовано смесь органических и неорганических кислот (3-4), которые обеспечили осаждение гетероциклических соединений ОММ. Процесс экстракции проходила в нескольких стадиях.

При настаивании образовалась слой масла и густой черный слой.

Очищенное масло пропускали через колонку с $\mathrm{K}_{2} \mathrm{CO}_{3}$ для полной нейтрализации.

Оптимальные режимы технологических параметров процесса экстракции ОММ приведены в табл. 2.

Таблица 2

Технологические параметры при очистке ОММ методом экстракции

\begin{tabular}{|l|c|c|c|c|}
\hline \multicolumn{1}{|c|}{ Наименование } & Температура, ${ }^{0} \mathrm{C}$ & $\begin{array}{c}\text { Соотношение } \\
\text { экстрагент / сы- } \\
\text { рье }\end{array}$ & $\begin{array}{c}\text { Время кон- } \\
\text { такта, ми- } \\
\text { нут }\end{array}$ & $\begin{array}{c}\text { Время настаива- } \\
\text { ния, минут }\end{array}$ \\
\hline Экстрагент I & $10-20$ & $1: 40$ & 20 & $15-17$ \\
\hline Экстрагент II & Окр. среды & $1: 25$ & 20 & $30-40$ \\
\hline Экстрагент III & 17 & $1: 10$ & 20 & $50-60$ \\
\hline
\end{tabular}

Степень осветления масла колебалась в пределах 92.7-95.5\%. Полученный густой черный слой отделяли от масла центрифугированием а затем, повторно использовали для экстракции масла. В конце подвергали термической обработке $\mathrm{T}=300{ }^{\circ} \mathrm{C}$ для получения коксового концентрата.

Проведенные исследования показали, что очистка ОММ трудоемкая технология и используемый метод экстракции обеспечивает эффективное удаление продуктов окисления ОММ. В отличие от других методов, метод 
экстракции обеспечивает стабильность эксплуатационных свойств очищенного масла.

References:

[1] Балтенас Р., Сафонов А.С. и др. Моторные масла. Производство. Свойства. Классификация. Применение: научно-техническое издание. - М.: Альфа-Лаб, 2000. 272 c.

[2] Пальгунов П.П., Сумароков М.В. Утилизация промышленных отходов. - М.: 1990.

[3] Проскурякова В.А. Химия нефти и газа. - Л.: Химия, 1989.

[4] http://www.npo64.ru/motornoe-maslo/

[5] Унгер Ф.Г. Фундаментальные аспекты химии нефти. Природа смол и асфальтенов. - Новосибирск: Наука, 1995. - 192 с. 


\title{
DISTURBANCE OF HEMOSTASIS IN ALLOXAN DIABETES AND WAYS ITS CORRECTION
}

\author{
D. Tursunov 1 , R. Sabirova 2 , A. Ikramov 3 , M. Kulmanova4, A. Ergashov 5
}

\section{Abstract}

Diabetes mellitus is a group of metabolic diseases in which there are high blood sugar levels over a prolonged period. Symptoms of high blood sugar include frequent urination, increased thirst, and increased hunger. If left untreated, diabetes can cause many complications. Treatment with Glucophage did not lead to a decrease in glucose, although there was an increase in insulin. In the treatment with retabolil, a significantly changed in these indices towards the improvement was not observed. Ecdysten in addition to a pronounced glycemic effect has the ability to normalize the indices of all links of hemostasis. The drugs used in the course of studies can be arranged according to their effectiveness in the following way: ecdysten - Glucophage - retabolil.

Keywords: diabetes, alloxan, hemostasis, insulin, blood serum, ecdysten, retabolil, glyukofage.

Сахарный диабет (СД) представляет одну из актуальных медико-социальных проблем современного общества и практического здравоохранения, что обусловлено высокой заболеваемостью и его распространенностью, частым возникновением хронических микро- и макрососудистых осложнений.

Изучение механизмов нарушений гемостаза при сахарном диабете 1 и 2 типов является одним из важных аспектов проблемы профилактики и лечения осложнений, ограничивающих срок жизнибольных [3]. По современным представлениям патогенез осложнений сахарного диабета рассматривается с позиций теории глюкозотоксичности, согласно которой хронически повышенный уровень глюкозы крови является ведущим фактором, инициирующим многообразные биохимические и структурные изменения в клетках и тканях [10]. Показано, что при сахарном диабете главным патогенетическим механизмом развития микроангиопатий является гликозилирование сосудистой стенки [9].

${ }^{1}$ Tursunov Djakhangir Xusanovich - teaching assistant of Tashkent medical academy, department of medical and biological chemistry, Uzbekistan.

${ }^{2}$ Sabirova Rikhsi Abduqadirovna - professor of Tashkent medical academy, department of medical and biological chemistry, Uzbekistan.

${ }^{3}$ Ikramov Akmal Muxammad - Shukhratovich - master student of Tashkent medical academy department of medical and biological chemistry, Uzbekistan.

${ }^{4}$ Kulmanova Munojat Usmanovna - professor, head of department of medical and biological chemistry of Tashkent medical academy, Uzbekistan.

${ }^{5}$ Ergashov Adkham Tadjimuradovich - associated professor of Tashkent medical academy, department of medical and biological chemistry, Uzbekistan. 
При сахарном диабете 1 и 2 типов подтверждена активация всех систем гемостаза, участвующих в регуляции тонуса кровеносных сосудов, состояния клеток крови и плазменных ферментных систем [7,8].

Дисфункция систем коагуляции и фибринолиза на ранних стадиях заболевания приводит к появлению ретинопатии и нефропатии $[9,10]$. При увеличении длительности заболевания нарастает концентрация фибриногена, снижается фибринолитическая активность, что создает условия для повышенной возможности тромбообразования $[3,4]$.

Современная стратегия лечения СД направлена на достижение оптимального уровня глюкозы и показателей липидного обмена в кратчайшие сроки, т.к. глюкоза и липиды при повышенной концентрации проявляют токсичность, которая может необратимо приводить к макро- и микроангиопатиям, а также поражению самих $\beta$-клеток поджелудочной железы, молекулярные механизмы которых мало изучены. В опубликованном в 2009 г. IDF «Общем руководстве по лечению сахарного диабета типа 2» подчеркивается необходимость поддержания HbA1c на уровне 6,5 или ниже, что сводит к минимуму опасность возникновения сосудистых осложнений диабета. Быстрая компенсация СД уменьшает в дальнейшем вероятность появления осложнений, что позволяет сократить дозу самих препаратов, которые имеют побочные эффекты и противопоказания.

В этом отношении наиболее перспективными является фитоэкдистероиды, выделенные из растений, которые не имеют побочных эффектов, особенно гормонального характера [1,2].

Широкомасштабные изучения фитоэкдистероидов показали, что они проявляют стимулирующее -оптимизирующее действие на обменные процессы в организме. На основе некоторых фитоэкдистероидов, выделенных из местного растительного сырья, в ИХРВ АН РУз создан препарат общеукрепляющего типа действия: экдистен. Он с успехом применяется в клинической и спортивной медицине при многих заболеваниях, в основе которых лежит преобладание катаболических процессов. Отдельными исследованиями также установлено гипогликемическое действие экдистена. Однако, комплексные исследования его гемостатических свойств не проводились [1,2].

В связи с этим выявление нарушений гемостаза и механизма действия экдистена на развитие аллоксанового диабета, обоснование возможности и целесообразности его практического использования определяет не только актуальность но и научную и медико-социальную значимость данной работы.

Цель работы: изучить нарушения гемостаза и оценить действие экдистена на показатели гемостаза при экспериментальном аллоксановом диабете.

Материал и методы исследования: Для решения поставленной цели эксперименты проведены на 70 крысах-самцах весом 130-150 гр., содержащихся на стандартном режиме питания. При проведении экспериментов руководствовались «Европейской конвенцией о защите позвоночных жи- 
вотных, которые используются для экспериментов и других научных целей» (Страсбург, 1985). Для воспроизведения модели диабета 60 крысам после карантина вводили аллоксан в дозе 13 мг на 100 г массы тела, однократно. О развитии диабета судили по содержанию глюкозы в крови, который определяли на биохимическом анализаторе с использованием набора глюкозоксидазного теста фирмы Лахема. Через 7 дней после воспроизведения диабета, животные были разделены на 4 группы: 1-я 15 крыс с аллоксановым диабетом (АД), получавших перорально дистиллированную воду в дозе 0,5 мл на 100 г массы тела (контрольная); 2-я группа - 15 крыс с аллоксановым диабетом, получавшие экдистен в дозе 0,143 мг на 100 г массы тела внутрижелудочно (основная); 3-я группа - 15 крыс с аллоксановым диабетом, получавшие препарат сравнения глюкофажа в дозе 4,28 мг на 100 г массы тела; 4-я группа - 15 крыс с аллоксановым диабетом, получавшие препарат сравнения ретаболил в дозе 0,0714 мг на 100 г массы тела. 10 крыс составили интактную группу. Препараты вводили в течение 14 дней, забой животных проводили на 14 и 21 сутки от начала эксперимента. Выбор препаратов сравнения обоснован тем, что глюкофаж является практически единственным противодиабетическим средством, снижающим риск смерти от диабета и его серьезных осложнений. Он снижает скорость всасывания углеводов в тонком кишечнике, повышает чувствительность периферических тканей к инсулину, тормозит процессы глюконеогенеза и гликогенолиза в печени и снижает системную гиперинсулинемию. Второй препарат - ретаболил обладает анаболическим действием, выбор его обоснован тем, что экдистен также обладает анаболическим действием.

Результаты исследования обрабатывали с помощью прикладных программ Statistica 6, Biostat. Данные представлены в виде средних арифметических значений (M) и стандартных отклонений (m). Для сравнения выборок применяли t-критерий Стьюдента или парный критерий Вилкинсона. Уровень значимости считали достоверными при $\mathrm{P}<0,05$.

Результаты исследования и их обсуждение. В развитии диабетических ангиопатий важное патогенетическое значение имеют изменения системы гемостаза и гемореологические нарушения $[4,5,6]$. Микроциркуляторные сосудистые нарушения при сахарном диабете (СД) носят вторичный характер, но необходимость их коррекции выходит на первый план, так как они являются причиной стойких, не купируемых сахароснижающими препаратами патологических состояний (нефропатия, ретинопатия и др.), ведущих к инвалидизации $[8,9]$.

Необходимо отметить, что сахарный диабет характеризуется разнообразными изменениями в системе гемостаза, что подтверждается огромным количеством работ по этой теме в мировой литературе. При сахарном диабете страдают практически все звенья системы гемостаза, что приводит к развитию протромботического состояния и тяжелым сердечно-сосудистым осложнениям. 
Таблица 1

Динамика изменения маркеров гиперглкемии при экспериментальном аллоксановом диабете и коррекции экдистеном

\begin{tabular}{|c|c|c|c|c|c|c|c|c|c|c|}
\hline \multirow{2}{*}{$\begin{array}{c}\text { Покоза- } \\
\text { тели }\end{array}$} & \multirow{2}{*}{$\begin{array}{l}\text { Ин- } \\
\text { так- } \\
\text { ная }\end{array}$} & \multicolumn{3}{|c|}{$\begin{array}{c}\text { АД }+\mathrm{H}_{2} \mathrm{O} \\
\mathrm{n}=7\end{array}$} & \multicolumn{2}{|c|}{$\begin{array}{c}\text { АД + экдистен, } \\
\mathrm{n}=7\end{array}$} & \multicolumn{2}{|c|}{$\begin{array}{c}\text { АД + глюко- } \\
\text { фаж, } \\
\text { n =7 }\end{array}$} & \multicolumn{2}{|c|}{$\begin{array}{c}\text { АД + ретабо- } \\
\text { лил, } \\
\text { n =7 }\end{array}$} \\
\hline & & 7 & 1 & 21 сут. & 14 сут. & 21 сут. & 14 сут. & 21 сут. & 14 сут. & 21 сут \\
\hline & 4,85 & 8,37 & 71 & 895 & 6,78 & 5,75 & 7,88 & 7,02 & 8,41 & 8,04 \\
\hline $\begin{array}{l}\text { C-реан } \\
\text { ный б } \\
\text { (мг) }\end{array}$ & $\begin{array}{c}4,83 \pm \\
0,4\end{array}$ & $\begin{array}{c}18 \pm \\
1,8\end{array}$ & & 1 & & & $\begin{array}{c}10,1 \pm \\
1,37\end{array}$ & & $\begin{array}{l}13,1 \pm \\
1,3\end{array}$ & $\begin{array}{c}12,6 \pm \\
1,2\end{array}$ \\
\hline $\begin{array}{l}\text { Инсулин } \\
\text { мкЕд/мл }\end{array}$ & $\begin{array}{l}4,3 \pm \\
0,49\end{array}$ & $\begin{array}{l}0,7 \pm \\
0,12 \\
\end{array}$ & $\begin{array}{c}0,37 \pm \\
0,05\end{array}$ & $\begin{array}{c}0,32 \pm \\
0,05\end{array}$ & $\begin{array}{c}3,45 \pm \\
0,5\end{array}$ & $\begin{array}{c}4,75 \pm \\
0,95\end{array}$ & $\begin{array}{c}4,98 \pm \\
0,25\end{array}$ & $\begin{array}{c}4,9 \pm \\
4,1 \\
\end{array}$ & $\begin{array}{l}2,1 \pm \\
0,43 \\
\end{array}$ & $\begin{array}{c}1,48 \pm \\
0,21\end{array}$ \\
\hline
\end{tabular}

Как видно из представленных в таблице 1 данных, у животных контрольной группы наблюдается выраженная гипергликемия. На 7, 14 и 21 день развития АД уровень глюкозы по сравнению с интактными животным достоверно повышается в $1,7,1,8$ и 1,84 раза соответственно. При этом содержание инсулина в исследованные сроки снижается в 6,1, 11,6 и 13,4 раза соответственно по сравнению интактной группой.

При лечении экдистеном на 14 день уровень глюкозы снижается в 1,28 раза, а на 21 день - 1,55 раза по сравнению с тем же периодом контрольной группы. При лечении глюкофажем и ретаболилом в исследованные сроки установлено их менее выраженный гиполипидемический эффект по сравнению с экдистеном.

Лечение экдистеном приводит повышению содержания инсулина на 14 и 21 день 9,3 и 14,8 раза по сравнению с нелеченной группой. В то же время ретаболил оказал менее выраженное повышение инсулина по сравнению с экдистеном и глюкофажем.

Все изученные препараты снизили содержание C-реактивного белка по сравнению с животными, которые не повергались лечение. Необходимо отметить более выраженное действие экдистена, так при лечении этим препаратом снижение содержания C-реактивного белка составило 2,4 и 1,9 раза соответственно по сравнению с нелеченной группой.

Таким образом, при введении экдистена снижение уровня глюкозы и повышение инсулина происходит постепенно и становится статистически достоверным в течении трех недель, практически приближаясь до уровня интактных животных.

Лечение глюкофажом не привело к снижению уровня глюкозы, хотя наблюдалось повышение инсулина. При лечении ретаболилом достоверное изменение этих показателей в сторону улучшение не наблюдалось.

Получено значительное количество новых фактов, доказывающих сложный механизм развития диабетических ангиопатий, включающий метаболические, гормональные, гемореологические, аутоиммунные и другие нарушения [3,4]. Возникает необходимость применения лекарственных препаратов, воздействующих на различные звенья патогенеза сосудистых 
поражений. Фармакологическая коррекция включает помимо сахароснижающей терапии гиполипидемические, дезинтоксикационные препараты, гипокоагулянты, дезагреганты, ангиопротекторы, спазмолитики и др. [10].

При исследовании показателей гемостаза у крыс отмечалось достоверное повышение всех показателей, кроме фибриногена, у животных контрольной группы по отношению интактной группы (табл. 2).

Таблица 2

Изменение показателей гемостаза при экспериментальном аллоксановом диабете и коррекции экдистеном

\begin{tabular}{|c|c|c|c|c|c|c|c|c|c|c|}
\hline \multirow{2}{*}{$\begin{array}{c}\text { Покоза- } \\
\text { тели }\end{array}$} & \multirow{2}{*}{$\begin{array}{l}\text { Ин- } \\
\text { так- } \\
\text { ная }\end{array}$} & \multicolumn{3}{|c|}{$\begin{array}{c}\mathrm{AД}+\mathrm{H}_{2} \mathrm{O} \\
\mathrm{n}=7\end{array}$} & \multicolumn{2}{|c|}{$\begin{array}{c}\text { АД + экдистен, } \\
\text { n }=7\end{array}$} & \multicolumn{2}{|c|}{$\begin{array}{c}\text { АД + глюко- } \\
\text { фаж, } \\
\mathrm{n}=7\end{array}$} & \multicolumn{2}{|c|}{$\begin{array}{c}\text { АД + ретабо- } \\
\text { лил, } \\
\mathrm{n}=7\end{array}$} \\
\hline & & 7 сут. & 14 сут. & 21 сут. & 14 сут. & 21 сут. & 14 сут. & 21 сут. & 14 сут. & 21 сут. \\
\hline $\begin{array}{l}\text { АЧТВ } \\
\text { (сек) }\end{array}$ & $\begin{array}{c}30 \\
\pm 0,36 \\
\end{array}$ & $\begin{array}{c}34,1 \pm 0 \\
, 4 \\
\end{array}$ & $\begin{array}{c}38,5 \pm 1 \\
, 3 \\
\end{array}$ & $42 \pm 0,5$ & $33 \pm 0,96$ & $\begin{array}{c}34,8 \pm 0 \\
, 95 \\
\end{array}$ & $\begin{array}{c}38,5 \pm 1 \\
, 5 \\
\end{array}$ & $24 \pm 1,4$ & $37 \pm 1,2$ & $\begin{array}{c}38,4 \pm 1 \\
, 8 \\
\end{array}$ \\
\hline ПТИ \% & $\begin{array}{c}86 \\
\pm 0,7 \\
\end{array}$ & $\begin{array}{c}119 \pm 5 \\
5 \\
\end{array}$ & \begin{tabular}{|c|}
$129,8 \pm$ \\
1,7 \\
\end{tabular} & $\begin{array}{c}128,6 \pm \\
1,17 \\
\end{array}$ & $\begin{array}{c}98,6 \pm 3 \\
48 \\
\end{array}$ & $\begin{array}{c}90 \pm 0,8 \\
8 \\
\end{array}$ & $\begin{array}{c}100 \pm 2 \\
7 \\
\end{array}$ & $\begin{array}{c}97,3 \pm 1 \\
, 9 \\
\end{array}$ & $\begin{array}{c}111 \pm 2 \\
3 \\
\end{array}$ & $\begin{array}{c}108,3 \pm \\
1,53 \\
\end{array}$ \\
\hline MHO & $\begin{array}{l}2,3 \pm \\
0,03\end{array}$ & $\begin{array}{l}2,4 \pm \\
0,03\end{array}$ & $\begin{array}{c}2,55 \pm \\
0,04 \\
\end{array}$ & $\begin{array}{c}2,56 \pm \\
0,04 \\
\end{array}$ & $2,3 \pm 0,1$ & $\begin{array}{c}2,4 \pm 0 \\
04\end{array}$ & $\begin{array}{c}2,5 \pm 0 \\
13 \\
\end{array}$ & $\begin{array}{c}2,56 \pm 0 \\
, 1 \\
\end{array}$ & $\begin{array}{c}2,5 \pm 0 \\
04\end{array}$ & $\begin{array}{c}2,53 \pm 0 \\
, 05 \\
\end{array}$ \\
\hline $\begin{array}{c}\text { Тромби- } \\
\text { новое } \\
\text { время } \\
\text { (сек) } \\
\end{array}$ & $\begin{array}{l}26 \pm \\
0,36\end{array}$ & $\begin{array}{c}24,5 \pm \\
0,76\end{array}$ & $\begin{array}{c}25,1 \pm \\
0,3\end{array}$ & $\begin{array}{c}25,5 \pm \\
0,42\end{array}$ & $\begin{array}{c}28,3 \pm 0 \\
85\end{array}$ & $27 \pm 0,8$ & $\begin{array}{c}24,2 \pm 0 \\
, 9\end{array}$ & $\begin{array}{c}25 \pm 1,0 \\
2\end{array}$ & $\begin{array}{c}26,6 \pm 2 \\
, 9\end{array}$ & $\begin{array}{c}27,6 \pm 2 \\
, 2\end{array}$ \\
\hline $\begin{array}{c}\text { Фибри- } \\
\text { ноген } \\
\text { плазмы } \\
\text { г/л }\end{array}$ & $\begin{array}{l}2,4 \pm \\
0,08\end{array}$ & $\begin{array}{l}2,5 \pm \\
0,05\end{array}$ & $\begin{array}{l}2,5 \pm \\
0,04\end{array}$ & $\begin{array}{c}2,51 \pm 0 \\
04\end{array}$ & $\begin{array}{c}2,1 \pm 0,0 \\
8\end{array}$ & $\begin{array}{c}1,8 \pm 0 \\
06\end{array}$ & $\begin{array}{c}2,1 \pm 0 \\
11\end{array}$ & $\begin{array}{c}1,96 \pm 0 \\
, 05\end{array}$ & $\begin{array}{c}2,96 \pm 0 \\
, 2\end{array}$ & $\begin{array}{c}3,2 \pm 0 \\
22\end{array}$ \\
\hline
\end{tabular}

Примечание: * - Р>0,05 по отношению к интактной и контрольной группы соответственно.

Как видно из таблицы в контрольной группе увеличивается значение АЧТВ, т.е. начинается возрастание количества антител к фосфолипидам, которые характеризуют артериальные и венозные тромбозы. Так на 7,14 и 21 дни развития аллоксанового диабета АЧТВ повышается в 1,13, 1,28 и 1,4 раза соответственно по сравнению с животными интактной группы. Следовательно, можно говорит о антифосфолипидном синдроме [11] с развитием АД. Это подтверждает также повышение ПТИ и МНО, связанные с риском тромбозов. Из данных таблицы видно, что значение ПТИ на 7, 14 и 21 сутки развития аллоксанового диабета в 1,38, 1,5 и 1,49 раза больше чем у интактных животных. Достоверных изменений в содержании МНО на 7 сутки развития аллоксанового диабета по сравнению с интактными животными не происходит, но на 14 и 21 сутки установлено его повышение в 1,10 и 1,11 раза по сравнению с интактными животными соответственно.

В контрольной группе тромбиновое время достоверно укорачивается 
только на 21 сутки развития аллоксанового диабета по сравнению с интактной группы на 2\%. В содержании количества фибриногена во все сроки развития аллоксанового диабета достоверных изменений нами не выявлено. А это может свидетельствовать о начале воспалительных процессов, что также подтверждает повышение концентрации C - реактивного белка, который на 7, 14 и 21 день развития аллоксанового диабета возрастает в 3,7, 3,9 и 4,3 раза соответственно по сравнению с интактной группой.

При коррекции экдистеном в течении 14 и 21 дня значение АЧТВ снижается на 14,3 и 24,3\% соответственно по сравнению с контрольной группой. В то же время при лечении глюкофажем и ретаболилом значение АЧТВ по сравнению с контрольной группой снизилось на 5,2, 19,1 и 3,9, $8,6 \%$ соответственно.

Лечение экдистеном в течение 14 и 21 дня достоверно снижает содержание ПТИ по сравнению с животными не леченной группы на 24,1 и 30,2\% соответственно. При лечении глюкофажем нами установлено снижение ПТИ на 23 и 24,4\% соответственно по сравнению с контрольной группой в исследованные сроки. Ретаболил по сравнению с экдистеном и глюкофажем менее выраженно снижает содержание ПТИ и в исследованные сроки оно составило 14,5 и 15,8\% соответственно по равнению с контрольной группой.

Достоверных изменений в содержании МНО при лечении экдистеном, глюкофажем и ретаболилом в течение 14 и 21 дня нами не обнаружено. При лечении экдистеном на 14 и 21 день установлено удлинение тромбинового времени по сравнению с не леченной группой на 12,7 и 5,9\% соответственно. А при лечении глюкофажем и ретаболилом достоверных изменений тромбинового времени не выявлено.

Исследованные для коррекции показателей гемостаза препараты особого влияния на содержание фибриногена не оказали.

Как видно из таблицы лечение экдистеном особо эффективно, по сравнению глюкофажем и ретаболилом, при нарушениях в системе гемостаза. При этом наблюдается заметное и достоверное снижение АЧТВ, тромбинового времени, ПТИ, повышение которых является основной причиной сосудисто - тромбоцитарного гемостаза у крыс.

Таким образом, экдистен помимо ярко выраженного гликемического действия обладает способностью нормализовать показатели всех звеньев гемостаза. Использованные в ходе исследований препараты по эффективности можно располагать следующим образом: экдистен - глюкофаж - ретаболил.

Выводы:

1.При экспериментальном аллоксановом диабете происходят изменения в системе гемостаза в зависимости от срока его развития.

2.Исследованные для коррекции препараты по эффективности своего действия на показатели гемостаза располагаются следующим образом: экдистен - глюкофаж - ретаболил. 
References:

[1] Антиметастатические эффекты фитопрепаратов / Гольдберг Е.Д., Зуева Е.П., Разина Т.Г. и др. // Материалы VII Российского национального конгресса «Человек и лекарство». - М., 2000. - С. 487-488.

[2] Ашихмина Т.Я., Володин В.В., Матаев С.И. Второе международное совещание по фитоэкдистероидам (4-7 июля 2010 г., Сыктывкар, Россия) //Теоретическая и прикладная экология. - 2012. - №1. - С. 4-5.

[3] Влияние возраста и пола на показатели коагуляционного и сосудисто-тромбоцитарного гемостаза у больных сахарного диабета 2 типа / Е. И. Кондратьева, Г. А. Суханова, Л. С. Литвинова [и др.] // Клин. лаб. диагностика. - 2011. - № 8. - С. 41-43.

[4] Агрегационная активность форменных элементов крови у больных сахарным диабетом 1 и 2 типа / Б. И. Кузник, Ю. А. Витковский, М. Ю. Захарова [и др.] // Сахарный диабет. - 2012. - № 2. - С. 49-53.

[5] Нелаева Ю. В. Гемостатические изменения у больных сахарным диабетом 1 типа с диабетической нефропатией. Возможности коррекции альфа-липоевой кислотой. - Тюмень, 2003.

[6] Особенности гемостаза у больных сахарным диабетом 2 типа в сочетании с ишемической болезнью сердца / М. М. Петина, Г. Н. Гороховская, А. И. Мартынов // Мед. наука и образование Урала. - 2010. - Т. 11, № 1. - С. 30-36.

[7] Северина А. С., Шестакова М. В. Нарушение системы гемостаза у больных сахарным диабетом // Сахарный диабет. - 2004. - № 1.

[8] Роль коагуляции и воспаления в развитии диабетической нефропатии у больных сахарным диабетом 2 типа / Ю. В. Хасанова, А. А. Нелаева, А. Б. Галкина, И. В. Медведева // Сахарный диабет. - 2012. - № 1. - С. 31-34.

[9] Plasma Prekallikrein. A Risk Marker for Hypertension and Nephropathy in Type 1 Diabetes / Ayad A. Jaffa, Ramon Durazo-Arvizu, DeyiZheng [et al.]. - 2003.

[10]Platelets and Antiplatelet Therapy in Patients with Diabetes Mellitus / HeidarArjomand, BassamRoukoz, K. Satish [et al.]. - 2003.

[11]Долгов В. В., Свирин П. В. Лабораторная диагностика нарушений гемостаза. МЗ РФ, РМАПО, Каф КЛД. - Тверь: «Триада», 2005. - 227 с. 


\section{METHOD OF SELECTION AND OPERATION OF PUMPS WITH REGULATION OF CHANGE OF FREQUENCY OF ROTATION OF SHAFT OF THE SUBMERSIBLE ELECTRIC PUMPING EQUIPMENT}

\section{O. Kurbonov ${ }^{1}$}

\section{Abstract}

In this paper, the economic aspects of the use of frequency control of blood pressure are considered. Since frequency control provides the control of the speed of the $\mathrm{AD}$ without large losses of power in the rotor circuit, which impair the efficiency of the electric motor, and the losses in the TPCH are relatively small.

Keywords: Energy saving, speed, power loss, speed regulation.

Решение задачи энергосбережения зависит от способа управления величинами, образующими выходную мощность рабочей машины, т.к. этот способ существенно влияет на величину потерь энергии. На практике возможно три способа регулирования: принудительное изменение сопротивления магистрали, по которой передаётся транспортируемое текучее, изменение характеристик рабочей машины и регулирование угловой скорости электропривода. В тех случаях, когда имеется возможность изменить частоту вращения вала двигателя целесообразно регулировать подачу насоса изменением частоты вращения вала насоса (рис. 1).

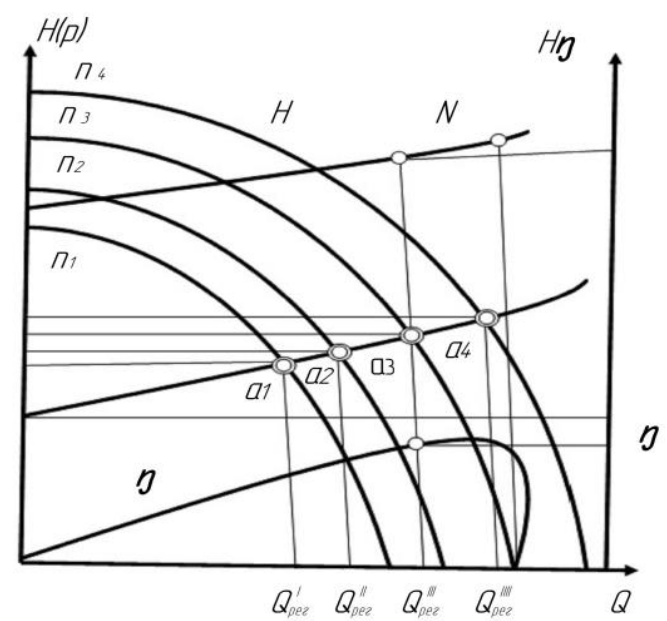

Рис. 1. График регулирования насоса изменением частоты вращения

1Oybek Kurbonov, assistant, Navoi State Mining Institute, Uzbekistan. 
Насос работает при частоте вращения $\mathrm{n} 1 \mathrm{n} 2$, и $\mathrm{n} 3, \ldots$, причем $\mathrm{n} 1<\mathrm{n} 2<\mathrm{n} 3$. Точки пересечения характеристик $\mathrm{H}=\mathrm{f}(\mathrm{Q})$ насоса с характеристикой трубопровода обозначены на графике

Q1 Q2, Q3,--, они определяют режимы работы установки при различных частотах вращения. С увеличением частоты вращения подача и напор увеличиваются, а с уменьшением - убывают.

Мощность и КПД определяются по графикам при указанной частоте вращения.

В отличие от способа регулирования дросселированием при $\mathrm{n}=\mathrm{const}$ данный способ регулирования дает возможность изменять расход в любом направлении.

Потерь энергии, обусловленных гидравлическим сопротивлением дросселя, здесь не происходит и поэтому данный способ регулирования экономичнее первого в эксплуатации[1]. Этот способ регулирования стал широко применяться в связи с внедрением в производство тиристорного привода.

Возможны следующие способы регулирования частоты вращения вала насоса:

1) в зависимости от хода технологического процесса осуществлять автоматическое включение.

2) в зависимости от хода технологического процесса осуществлять плавное автоматическое регулирование подачи насоса. Для решения этой задачи необходимо применение системы преобразователь частоты асинхронный двигатель (ПЧ-АД).

Внедрению любой системы регулируемого ЭП должны предшествовать расчеты, показывающие технические результаты и величину экономии энергии при плавном регулировании скорости.

Приведенный анализ затрат на электропривод позволяет представить в следующем виде:

$$
3=P K+\Delta P^{*} \gamma+3_{y K}-Q,
$$

где $\mathrm{P}$ - суммарный коэффициент отчислений для электропривода, равен сумме

$$
\left(P=E+P_{a}+P_{p o}\right),
$$

где Ра - норма амортизационных отчислений;

Рро - норма отчислений на ремонт и обслуживание;

Е - норма дисконта; у - стоимость 1 кВт ч энергии.

Затраты на регулируемый электропривод можно представить в виде:

$$
3=3{ }_{j}+3_{n}+3_{n p}+3_{k,}
$$

где Зд - приведенные затраты на электродвигатель;

Зп - приведенные затраты не преобразовательные устройства (на трансформатор, сглаживающие дроссели, реакторы, системы управления, защиты и автоматики);

Зпр - приведенные затраты на прочие элементы электропривода;

Зк - затраты на компенсацию реактивной мощности.

В этом случае в качестве преобразователя электрической энергии ис- 
пользуется вентильный преобразователь частоты (ПЧ), где в качестве вентилей применяются тиристоры или силовые транзисторы. По сравнению с системой ТРН-АД частотный способ обеспечивает плавное регулирование скорости в широком диапазоне, высокую жёсткость получаемых механических характеристик. Регулирование скорости АД не сопровождается увеличением его скольжения. Поэтому, в отличие от системы ТРН-АД, потери мощности скольжения при регулировании скорости оказываются небольшими.

В силу отмеченных преимуществ система ПЧ-АД находит в настоящее время всё большее применение в тех машинах и механизмах, где необходимо плавное регулирование скорости. Особенно перспективно применение системы ПЧ-АД в качестве привода насосов, вентиляторов и компрессоров, т. к. эти типы механизмов являются наиболее массовыми. Они потребляют $40 \%$ из общего количества электроэнергии, потребляемой электроприводом. Использование регулируемого электропривода позволяет сократить энергопотребление насосов на 25-30\%, вентиляторов - на $30 \%$, компрессоров на $40 \%$.

Регулирование скорости асинхронного электродвигателя изменением частоты напряжения статора наиболее перспективно и широко применяются в настоящее время. Принцип его заключается в том, что изменяя частоту fj питающего АД напряжения можно изменить скорость идеального холостого хода $\omega_{0}$ в соответствии с выражением:

где Р - число пар полюсов АД.

$$
\omega_{0}=2 \pi \cdot f_{1} / P \text {, }
$$

Частотный способ обеспечивает плавное регулирование скорости в широком диапазоне, высокую жесткость получаемых механических характеристик. Регулирование АД не сопровождается увеличением его скольжения.

Поэтому потери мощности при регулировании скорости оказываются небольшими. Для лучшего использования АД и получения высоких энергетических показателей его работы - коэффициентов мощности и полезного действия перегрузочной способности - одновременно с частотой необходимо изменять и подводимое к статору АД напряжение. Закон изменения напряжения при этом определяется характером зависимости момента сопротивления Мс от скорости.

При постоянном моменте сопротивления Mc = const напряжение на статоре должно регулироваться пропорционально его частоте $\mathrm{U}_{1}$

$$
\mathrm{U}_{1} / \mathrm{f}_{1}=\text { const. }
$$

Для момента сопротивления, пропорционально квадрату скорости электродвигателя Мc $=\mathrm{c} \omega^{2}$, что это соотношение имеет вид:

$$
\mathrm{U}_{1} / \mathrm{f}_{1}{ }^{2}=\text { const. }
$$

При моменте сопротивления, обратно пропорциональном скорости

$$
\mathrm{Mc}=\mathrm{c} / \omega \text {, }
$$

оно запишется в виде:

$$
\mathrm{U}_{1} / \sqrt{f_{1}}=\text { const. }
$$


Для реализации частотного способа регулирования скорости АД используются тиристорные преобразователи частоты ТПЧ (система ТПЧАД).

На вход ТПЧ подается стандартное напряжение сети Ui (220, 380 В и т.д.) промышленной частоты $f 1=50$ Гц, а с его выхода снимается переменное напряжение регулируемой частоты $\mathrm{f}_{\text {iper, }}$ значения которых находятся между собой в определенных соотношениях в зависимости от вида функции $\mathrm{Mc}=1 \Gamma((\breve{и ̆})$.Выходная частота и напряжение регулируются с помощью напряжения управления Uy, изменение которого определяет изменение частоты и тем самым скорости АД[2].

На рис.2 представлены механические характеристики АД при его управлении по наиболее простому закону.
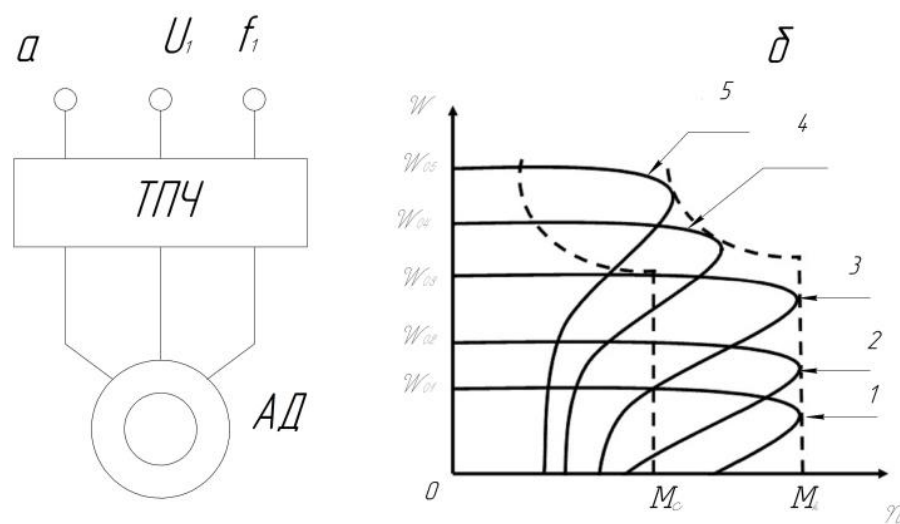

Рис. 2. Система ТПЧ-АД (а) и ее характеристики (б)

Механические характеристики по своим особенностям разделяются на два семейства: характеристики, соответствующие частотам ниже номинальной (сетевой) $\mathrm{f}=50$ Гц и выше ее.

В области частот $\mathrm{f}_{1}$ per $<\mathrm{f}_{1}$ (характеристики 1,2$)$ критический момент $\mathrm{M}_{\kappa}$ при изменении частоты не изменяется, и перегрузочная способность электродвигателя остается постоянной. Отметим, что закон управления является приближенным, так как при его выводе не учитывался ряд факторов. Поэтому в области малых скоростей АД несколько снижается критический момент Мк. Поэтому для поддержания $\mathrm{M}_{\mathrm{K}}=\mathrm{const}$ напряжение при малой частоте должно изменяться по более сложному закону.

В области частоты $f_{1 \text { per }}>f_{1}$ (характеристики 4,5 ) согласно закону: $U_{1 p e r} / /$ $f_{1 p e r}=$ const напряжение на статоре АД должно управления быть больше номинального. Однако по условиям нормальной работы АД нельзя повышать его напряжение сверх номинального. Поэтому регулирование в этой области ведется при $U_{1 p e r}=U_{1}-$ const, в связис чем Мк будет уменьшаться при увеличении частоты.

Частотное управление является экономичным, так как обеспечивает регулирование скорости АД без больших потерь мощности в роторной 
цепи, ухудшающих КПД электродвигателя, а потери в ТПЧ относительно малы.

В силу отмеченных преимуществ система ТПЧ-АД находит в настоящее время все большее применение.

References:

[1] Николаев В.Г. Выбор оптимальных парамет ров насосного оборудования и способов управления им. // Механизация и электрификация семьского хозяйства. -2008. - № 1. - С. 43-46.

[2] Махмудов А.М., Худайбердиев Ш.М. Определение основных параметров энергоэффективности работы насосных установок в технологии подземного выщелачивания // Науч.-техн. и произв. журнал "Горный вест-

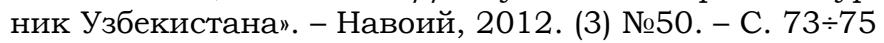




\title{
THE INDICES OF PLATELET HOMEOSTASIS IN WOMEN WITH A METABOLIC SYNDROME IN THE PRE-AND POSTMENOPAUSAL PERIOD
}

\author{
N. Islamova ${ }^{1}, N$. Mukhamedova ${ }^{2}$
}

\begin{abstract}
The results of a clinical laboratory examination of women with MS in the preand post-menopausal period are indicative of pronounced changes in all indicators. In women with MS in the postmenopausal period, pronounced changes in endothelial dysfunction, activation of the procoagulant and fibrinolytic links of the hemostatic system are noted. Adhesive and aggregation activity of platelets is strengthened; Hyperfermentemia due to disturbance of membrane structures of mitochondria of hepatocytes.
\end{abstract}

Keywords: homeostasis system, dissociates, postmenopausal, premenopausal, disco- echinocytes, platelet counts.

Actuality. According to the World Health Organization, the metabolic syndrome (MS) due to the widespread and high level of mortality is considered a global medical and social problem. Currently, the rate of obesity has epidemic values, especially in economically developed countries. According to the study «International Day for Evolution of Abdominal obesity» (IDEA), which was conducted in 63 countries, including 168,000 people aged from 18 to 60 years, $24 \%$ of men and $27 \%$ of women were obese (BMI $>30$ ), while $40 \%$ of men and $30 \%$ of women were overweight $(25>\mathrm{BMI}<30)$. According to analysts, by 2025 the number of obese patients in the world will double, $40 \%$ of men and $50 \%$ women will suffer from this disease. From the first days of independence of our country on the organization of a fundamentally new, high-quality medical services to the population made the program activities and implement effective health system model and the positive results achieved. In current year, the next stage of development of medicine has been started and numerous events are being held. As the result, metabolic syndrome in women has been reduced by $13.6 \%$ percent and $2.6 \%$ percent before and after the stage of menopause respectively.

Material and methods. 88 women with MS in pre- and postmenopausal periods aged from 40 to 65 years, years; 14 women of the control group at the similar age without MS. Is substantiated by the divan objective, clinical, biochemical, homeostasis and statistical study methods of the research. The statistical processing has confirmed the accuracy of the obtained results.

${ }^{1}$ Nodira Islamova, master student of Tashkent medical academy, Uzbekistan.

${ }^{2}$ Nurkhan Mukhamedova, PhD, scientist of department medical and biological chemistry of Tashkent medical academy Uzbekistan. 
Results and discussion. It was demonstrated the close relationship between systemic inflammatory syndrome and indicators of vascular-platelet links of homeostasis system, in particular, the individual risk factors of development of vascular disorders in women with MS during pre- and postmenopausal periods.

Table 1

Comparative characteristicsof the platelet count of the homeostasis system inwomen with MS in thepre-and postmenopausal periods

\begin{tabular}{|l|c|c|c|}
\hline \multicolumn{1}{|c|}{ Indicators } & $\begin{array}{c}\text { Comparison n=14 } \\
\text { group }\end{array}$ & $\begin{array}{c}\text { Women with MS } \\
\text { premenopausal } \\
\mathbf{n = 4 0}\end{array}$ & $\begin{array}{c}\text { Women with MS post- } \\
\text { menopausal n=48 }\end{array}$ \\
\hline Dissociates,\% & $85.4 \pm 1.21$ & $71.2 \pm 1.21^{* * *}$ & $61.1 \pm 1.21^{* * *}$ \\
\hline Disco -echinocytes, \% & $11.4 \pm 0.32$ & $20.8 \pm 0.71^{* * *}$ & $20.8 \pm 1.86^{* * *}$ \\
\hline Sphero -echinocytes, \% & $1.54 \pm 0.11$ & $4.04 \pm 0.13^{* * *}$ & $5.61 \pm 0.44^{* * *}$ \\
\hline Spherocytes, \% & $1.51 \pm 0.12$ & $3.99 \pm 0.23^{* * *}$ & $3.99 \pm 0.23^{* * *}$ \\
\hline Platelet counts & $256.0 \pm 11.32$ & $182.6 \pm 8.71^{* * *}$ & $178.4 \pm 7.8^{* * *}$ \\
\hline $\begin{array}{l}\text { Number of blood activated } \\
\text { platelets, \% }\end{array}$ & $12.41 \pm 0.23$ & $18.71 \pm 0.23^{* * *}$ & $13.46 \pm 8.96$ \\
\hline $\begin{array}{l}\text { Platelet aggregation rate } \\
\text { with ristomycin, \% }\end{array}$ & $94.8 \pm 6.51$ & $128.3 \pm 6.93^{* * *}$ & $118.71 \pm 1.17^{* * *}$ \\
\hline $\begin{array}{l}\text { Platelet aggregation rate } \\
\text { of with adrenalin, \% }\end{array}$ & $80.4 \pm 5.76$ & $70.8 \pm 5.43$ & $76.8 \pm 6.53$ \\
\hline $\begin{array}{l}\text { Platelet aggregation rate } \\
\text { of 30 sec \% min }\end{array}$ & $11.81 \pm 0.57$ & $9.12 \pm 0.49^{* * *}$ & $8.14 \pm 0.71^{* * *}$ \\
\hline $\begin{array}{l}\text { Platelet aggregation time } \\
\text { (min) }\end{array}$ & $8.71 \pm 0.43$ & $7.08 \pm 0.31^{* *}$ & $6.54 \pm 0.53^{* *}$ \\
\hline
\end{tabular}

Note:* - significant differences to the comparison group

$$
(*-\mathrm{P}<0.05, * *-\mathrm{P}<0.01, * * *-\mathrm{P}<0.001)
$$

Premenopausal women with MS had significant decrease in the content of dissociates, averaged $71.2 \pm 1.21 \%$ vs. $85.4 \pm 1.21 \%$ in healthy women that is on $16.6 \%$ lower than baseline values $(\mathrm{P}<0.001)$. In this cohort of women the rate of disco-echinocytes increased on average by 1.8 times and amounted to $20.8 \pm 0.71 \%$ vs. $11.4 \pm 0.32 \%$ in the comparison group.A similar pattern observed regarding spheroechinocytes, which rate in women with MS during premenopausal period was $4.04 \pm 0.31 \%$, while in healthy women of reproductive age it was equal to $1.54 \pm 0.11 \%$ that is 2.6 -fold $(\mathrm{P}<0.001)$ higher than the initial valuesRegarding spherocytes we observed similar dynamics, i.e. the rate of this form of platelets 2.6-fold exceeded the initial levels $(\mathrm{P}<0.001)$.There was significant decrease in the number of platelets in blood plasma, accounting in postmenopausal women with MS for $178.4 \pm 7.81 \%$, whereas in the comparison group it was equal to $256.0 \pm 11.2 \% / 1$, respectively, indicating decrease in platelet count on average $30.3 \%(\mathrm{P}<0.001)$.In women with $\mathrm{MS}$ during postmenopausal period was observed significant decrease in the percentage of dissociates, averaged $64.42 \pm 5.56 \%$ vs. $85.4 \pm 1.21 \%$ in healthy women, that is on $24.6 \%(\mathrm{P}<0.01)$ lower 
the initial values. Reduction of normal forms of platelets (dissociates) was accompanied by significant increase in pathological forms of blood platelets.

\section{Conclusions}

In women during menopause, increase of blood platelets adhesion and aggregation properties, enhanced thrombin production and platelet morphology change are the factors of DIC syndrome that plays the important role in the diagnosis for thrombohemorrhagic disorders.

\section{References:}

[1] Mertens I., Van Gaal L.F. Obesity, haemostasis and the fibrinolytic system // Obes Rev.- 2002. - Vol.3, №2. -P. 85-101.

[2] Miller G.J. Lipoprotein and thrombosis: effects of lipid lowering// Curr Pin Lipidol. 1995. - №6. -P. 388-342.

[3] Paradhan A.D., Manson J.E., Rifai N., Buring J.E., Ridker P.M. C-reactive protein, interleukin 6, and risk of developing type 2 diabetes mellitus //JAMA. - 2015. - Vol.286. P. 327-334.

[4] Poehlman E.T., Toth M.J., Ades P.A., Rosen C.J. Menopause -associated changes in plasma lipids, insulin -like growth factor I and blood pressure: a longitudinal study // Eur J Clin Invest. - 2016. - Vol.27, №4. -P. 322-326.

[5] Poehlman E.T., Toth M.J., Gardner A.W. Changes in energy balance and body composition at menopause: a controlled longitudinal study// Ann Intern Med.- 2005. Vol.123, №9. -P. 673-675.

[6] Polac I., Stachowiak G., Jedrzejczyk S., Pertynski T., Sobczuk A., Pakalski A., Stetkiewicz T., Owczarek D. [Assessment of fat tissue distribution impact on selected prothtrombin and fibrinolytic factors in pre-and postmenopausal women] // Ginekol Pol.- 2011. - Vol.71, №9. -P. 1083-1088.

[7] Ragab A., Abousamra N.K., Higazy A., Saleh O. relationship between insulin resistance and some coagulation and fibrinolytic parameters in patients with metabolic syndrome // Lab Hamates. - 2016. - Vol.14, №1. -P. 1-6.

[8] Ramasamy R., Yan S.F., Schmidt A.M. The RAGE axis and endothelial dysfunction: maladaptive roles in the diabetic vasculature and beyond // Trends Cardiovascurar Med.2005. - Vol.15. -P. 237-243.

[9] Raz O., Rogowski O., Shapira I., Maharshak N., Karni Y., Berliner S. Dissociated effects of physical activity and weight loss on fibrinogen concentrations and markers of red blood cell aggregation. Relevance for life style modification in atherothrombosis // ClinHaemorheolMicrocirc. - 2007, - Vol.37, №3. -P. 253-262 


\section{B\&M Publishing}

Scientific enquiry in the contemporary world: theoretical basics and innovative approach. $9^{\text {th }}$ edition: research articles, B\&M Publishing, San Francisco, California. 2017. 234 pp.

PQN 100

ISBN-10:1-941655-46-7

ISBN-13:978-1-941655-46-7 